\title{
As Inovações Tecnológicas na Silvicultura Brasileira e seus Impactos sobre a Expansão desta Atividade
}

\author{
Alessandro Antonangelo \\ Engenheiro Agrônomo
}

Orientador: Prof. Dr. Carlos José Caetano Bacha

\begin{abstract}
Dissertação apresentada à Escola Superior de Agricultura "Luiz de Queiroz", da Universidade de São Paulo, para a obtenção do título de Mestre em Ciências, Área de Concentração: Economia Aplicada.
\end{abstract}

Piracicaba

Estado de São Paulo - Brasil

Novembro - 1996 
Dados Internacionais de Catalogação na Publicação (CIP) DIVISÃO DE BIBLIOTECA E DOCUMENTAÇÃO - Campus "Luiz de Queiroz"/USP

Antonangelo, Alessandro

As inovaçōes tecnológicas na silvicultura brasileira e seus impactos sobre a expansão desta atividade / Alessandro Antonangelo. - - Piracicaba, 1996.

$173 \mathrm{p}$.

Dissertação (mestrado) - - Escola Superior de Agricultura Luiz de Queiroz, 1997.

Bibliografia.

1. Inovação tecnologica 2. Produtividade 3. Reflorestamento 4. Silvicultura Brasil l. Título.

CDD 338.16

338.173495 


\title{
As Inovações Tecnológicas na Silvicultura Brasileira e seus Impactos sobre a Expansão desta Atividade
}

\author{
ALESSANDRO ANTONANGELO
}

Aprovada em: 05 / 02 / 1997

Comissão Julgadora:

Prof. Dr. Carlos José Caetano Bacha

ESALQ / USP

Prof. Dr. José Vicente Caixeta Filho

ESALQ / USP

Prof. Dr. Flávio Abranches Pinheiro

FCA - Botucatu / UNESP

Caplos Jose' Caetavo Bachen Prof. Dr. Carlos Jose Caetano Bacha Orientador 
Dedico aos meus amigos, pela ajuda, pela compreensão $e$ pelo amparo.

Dedico à minha família, pela estrutura, pelo incentivo, pelo carinho, pelo afago.

Dedico ao meu pai, Wilson; minha mãe, Marlene; meu irmão Giovani e minha irmã, Bianca; por, nesta caminhada, sempre estarem ao meu lado.

Dedico à Deus, por ter me oferecido luz, nas ocasiões em que tudo pareceu apagado. 


\section{AGRADECIMENTOS}

Esta dissertação foi realizada com o apoio financeiro da CAPES, a qual quero manifestar meus agradecimentos.

Meu muito obrigado, também, aos colegas, funcionários e docentes do Departamento de Economia e Sociologia Rural da ESALQ/USP, que em muito colaboraram para a realização deste trabalho.

Aos professores José Vicente Caixeta Filho e Rodolfo Hoffmann, do Departamento de Economia e Sociologia Rural da ESALQ/USP; e aos professores Luiz Carlos E. Rodriguez, Walter de Paula Lima e José Luiz Stape, do Departamento de Ciências Florestais da ESALQ/USP, expresso meus agradecimentos pelas leituras feitas a versões anteriores desta dissertação. Suas críticas e sugestões foram incorporadas a este texto, cabendo a mim os erros e omissões que ainda possam existir.

Ao professor Carlos José Caetano Bacha expresso minha gratidão pela forma inteligente, profissional e ao mesmo tempo amiga com que me orientou no desenvolvimento deste trabalho. 


\section{ÍNDICE}

Página

LISTA DE QUADROS

i

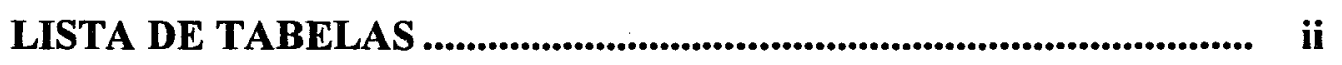

RESUMO

SUMMARY

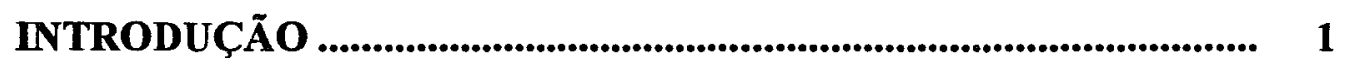

1- A SILVICULTURA NO BRASIL..................................................... 8

1.1- O Período Anterior aos Incentivos Fiscais Concedidos ao Reflorestamento/Florestamento ................................................ 8

1.1.1 - A Introdução da Eucaliptocultura no Brasil ..................... 9

1.1.2 - A Introdução da Pinocultura no Brasil .............................. 12

1.2- O Período dos Incentivos Fiscais Concedidos ao Reflorestamento/Florestamento ............................................... 14

1.3- O Período Posterior aos Incentivos Fiscais Concedidos ao Reflorestamento/Florestamento ..................................................

\section{2- EVOLUÇÃo TECNOLÓGICA NA SILVICULTURA} BRASILEIRA ......................................................................................... 22

2.1- Critérios de Classificação das Inovações Tecnológicas................ 23

2.2- Comparação de Sistemas de Produção Passados e Atuais na Eucaliptocultura e na Pinocultura........................................... 
2.3- As Pesquisas e as Inovações Tecnológicas na Silvicultura Brasileira.................................................................................

2.3.1 - Relação entre Pesquisa e Inovação Tecnológica .................... 36

2.3.2 - As Pesquisas na Silvicultura Brasileira ................................... 38

2.3.3 - A Evolução das Inovações Tecnológicas na Silvicultura Brasileira.................................................................................

3- A IMPORTÂNCIA DAS INOVAÇÕES TECNOLÓGICAS NA EXPANSÃO DA SILVICULTURA BRASILEIRA 60

3.1 - Relação entre Inovação Tecnológica, Produtividade e Custo 61

3.2 - A Equação da Área Reflorestada/Florestada 69

3.3 - Teste da Equação da Área Reflorestada/Florestada 75

4 - CONCLUSÕES 83

REFERÊNCIAS BIBLIOGRÁFICAS 87

APÊNDICE A Lista de Trabalhos Cientificos sobre a silvicultura no Brasil. 98

APÊNDICE B Evolução da Produtividade na Silvicultura Brasileira ................................................................. 156

APÊNDICE C Custo do Reflorestamento/Florestamento 161 APÊNDICE D Teste da Equação da Área Reflorestada/Florestada para todo o Brasil ............ 168

APÊNDICE E Teste da Equação da Área Reflorestada/Florestada para as Empresas de Papel e Celulose. 


\section{LISTA DE QUADROS}

\section{Página}

Quadro 1 Comparação de Sistemas de Produção de Eucalipto.......

28

Quadro 2 Comparação de Sistemas de Produção de Pinus...............

Quadro 3 Trabalhos de Pesquisa Referentes a Eucalipto e Pinus Publicados nos Congressos Florestais Brasileiros e nas Revistas Floresta, Árvore e IPEF..........

Quadro B1 Produtividades Médias do Eucalipto e do Pinus.............. 160

Quadro C1 Coeficientes Técnicos e Quantidades Totais de Insumos e Fatores de Produção Utilizados num Ciclo Produtivo da Silvicultura Brasileira ........................ 
LISTA DE TABELAS

Página

Tabela 1 Área Reflorestada/Florestada no Brasil por certos Grupos (em hectares) ...........................................................

Tabela 2 Evolução da quantidade de trabalhos científicos publicados sobre espécies exóticas (pinus e eucalipto), espécies nativas e espécies de araucária........

Tabela 3 Percentagem de Estabelecimentos Silvicultores que Usam Adubos, Corretivos e Defensivos

Tabela 4 Uso e Procedência da Força Utilizada nos Trabalhos Realizados na Silvicultura.

Tabela 5 Percentagem de Tratores Agrícolas Usados na Silvicultura Segundo a Classe de Potência.

Tabela 6 Percentagem de Estabelecimentos Silvicultores que Usam a Irrigação e Percentagem da Área Total que é Irrigada.

Tabela 7 Evolução da Produtividade Média do Eucalipto, do Pinus e da Silvicultura Brasileira

Tabela 8 Evolução do Custo de Implantação e Manutenção deFlorestas de Eucalyptus spp e Pinus spp.........................

Tabela 9 Evolução do Custo do Reflorestamento/Florestamento Supondo Sistema de Produção Constante e Nível de Produtividade Constante (25 estéreos/hectare/ano. 
Tabela 10 Acréscimo de Área Total Reflorestada/Florestada com Incentivos Fiscais no Brasil (At), Acréscimo de Área Reflorestada/Florestada (com Eucalipto e Pinus) com Incentivos Fiscais no Brasil (Aep), Preços Médios Recebidos pela Lenha Oriunda da ÁreaReflorestada/Florestada (PP), Valor dos Incentivos Fiscais ao Reflorestamento/Florestamento (I), Produtividade Média da Silvicultura Brasileira (Pr) e Custos do Reflorestamento/Florestamento (C).....

Tabela 11 Acréscimo de Área reflorestada/florestada com pinus e eucalipto pelas empresas de papel e celulose (Aep); Preço Médio do estéreo de madeira destinada à fabricação de celulose $(P)$; índice de evolução dos incentivos fiscais (I); Produtividade Média da silvicultura brasileira (Pr) e Custos do reflorestamento/florestamento levantados para São Paulo.

Tabela C1 Preços Pagos Pelos Agricultores Pelo Arrendamento da Terra, Mão-de-Obra (Salário Rural), Mudas, Horas de Uso de Equipamentos, Defensivos (Formicida) e Adubo. Valores em Dólares de Dezembro de 1992

Tabela C2 Custo do Arrendamento da Terra, Custo da Mãode-obra, Custo de Mudas, Custo do Uso de Equipamentos, Custo de Formicida, Custo de Adubo NPK e custo do Reflorestamento/Florestamento. Valores em Dólares de Dezembro de 1992 e para 1 hectare (1969 a 1986).....

Tabela C3 Custo do Arrendamento da Terra, Custo da Mãode-obra, Custo de Mudas, Custo do Uso de Equipamentos, Custo de Formicida, Custo de Adubo NPK e Custo do Reflorestamento/Florestamento.Valores em Dólares de Dezembro de 1992 e para 1 hectare (1981 a 1992)..... 


\section{As Inovações Tecnológicas na Silvicultura Brasileira e seus Impactos sobre a Expansão desta Atividade}

\section{Autor: Alessandro Antonangelo Orientador: Prof. Dr. Carlos José Caetano Bacha}

\section{Resumo}

O objetivo deste trabalho é fazer uma análise das inovações tecnológicas ocorridas na silvicultura brasileira, bem como estudar os impactos destas inovações sobre a expansão desta atividade. A expansão da silvicultura é avaliada através da expansão da área reflorestada/florestada. Além disso, o estudo é concentrado nos gêneros Eucalyptus e Pinus, cujas espécies são as mais plantadas no Brasil.

A silvicultura brasileira apresentou três fases na sua evolução: a primeira fase correspondeu ao período que vai do descobrimento do Brasil até o início dos incentivos fiscais ao reflorestamento/florestamento (em 1965); a segunda fase abrange o período de vigência dos incentivos fiscais ao reflorestamento/florestamento (1966 a 1988); e a terceira fase cobre o período pós-incentivos fiscais ao reflorestamento/florestamento (de 1989 até hoje).

A partir da segunda fase da silvicultura brasileira, houve uma grande expansão da área reflorestada/florestada, que saltou de quase 500 mil hectares em 1964 para 5,9 milhões de hectares em 1984. Da comparação dos sistemas de produção iniciais (década de 50) e atuais (década de 90) do eucalipto e do pinus, percebe-se que houve uma grande evolução da tecnologia utilizada, a qual pode ser atribuída a um processo de maior desenvolvimento da pesquisa (intensificado também a partir da segunda fase da evolução da silvicultura brasileira) e que acabou gerando um grande número de inovações tecnológicas importantes. 
As relações entre inovações tecnológicas e expansão da sivicultura brasileira são estabelecidas através da produtividade. Em geral, pode-se dizer que a evolução tecnológica ocorrida na silvicultura brasileira provocou um aumento geral da produtividade que, por sua vez, reduziu os custos do reflorestamento/florestamento. Esta redução elevou a rentabilidade da silvicultura, causando a sua expansão. Isto foi comprovado pela estimativa da equação da área reflorestada/florestada, que mostra a importância das inovações tecnológicas - ao lado do preço da madeira oriunda de matas plantadas e dos incentivos fiscais do Governo Federal ao reflorestamento/florestamento - para a expansão da área reflorestada/florestada ocorrida no Brasil. 


\section{SUMMARY}

\section{author: Alessandro Antonangelo adviser: Prof. Dr. Carlos José Caetano Bacha}

The objective of this study is to make an analysis of the technological innovations that occurred in Brazilian Forestry, as well as studying the impacts of these innovations on the increase of this activity. The expansion of forestry is evaluated by the expansion of reforested/forested area. Besides, the study is concerned about genus Eucalyptus and Pinus, whose species are the most cultivated in Brazil.

The Brazilian Forestry presented three phases in its evolution: the first phase, that corresponded to the period from the Brazilian discovery to the beginning of fiscal incentive to reforesting/foresting (in 1965); the second phase, that comprehends the period of fiscal incentives validity to reforesting/foresting (1966 to 1988); and the third phase, that encloses the period after fiscal incentives to reforesting/foresting (since 1989 until today).

Starting from the second phase of the Brazilian Forestry, there was a great increase of the reforested/forested area, that changed from almost 500 thousand hectares in 1964 to 5.9 millions of hectares in 1984. From the comparison among these initial sistens of eucalyptus and pine production (50's decade) and the present ones (90's decade), it's possible to notice that there were a large evolution of the technology used, which can be attributed to a process of bigger development of the research (started from the second phase of Brazilian Forestry too) and that caused a great number of important technological innovations. 
The relationship between technological innovation and Brazilian Forestry expansion is established by productivity. In general, it's possible to say that the technological innovation occurred in the Brazilian Forestry caused a general increase of productivity that, by its sides, reduced the costs of reforesting/foresting. This reduction increased the profitability of forestry, causing its expansion. This theory is proved by the equation of reforested/forested area, that shows the importance of technological innovations - beside the price of wood come from planted forests and fiscal incentives of Federal Government to reforesting/foresting - for the expansion of reforesting/foresting occurred in Brazil. 


\section{INTRODUÇÃO}

O objetivo deste trabalho é fazer uma análise das inovações tecnológicas ocorridas na silvicultura brasileira, bem como estudar os impactos destas inovações sobre a expansão desta atividade.

A expansão da silvicultura ${ }^{1}$ é avaliada através da expansão da área reflorestada/florestada ${ }^{2}$. Além disso, concentramos nossa atenção nos gêneros Eucalyptus e Pinus, cujas espécies são as mais plantadas no Brasil.

Para mostrar a relevância do presente trabalho, vamos analisar a silvicultura brasileira sob três aspectos: a sua importância para a sociedade (tendo em vista o que fornece), a expansão da área reflorestada/florestada e a sua evolução tecnológica. A seguir, apresentamos a revisão da bibliografia existente sobre cada um destes tópicos.

É de concordância geral a grande importância que se atribui às florestas (sejam elas nativas ou resultado do reflorestamento) em uma sociedade. Esta importância, contudo, não é dada somente à floresta propriamente dita ("área com árvores"), mas também a todo um conjunto de atividades a ela relacionadas e beneficios que dela se originam. Existem vários trabalhos que discutem a importância das florestas - e, assim, da própria silvicultura - para o contexto em que vivemos.

1 De acordo com a Metodologia do Censo Agropecuário de 1980 (IBGE, 1984, p.66) "silvicultura é a cultura de essências florestais e extração de produtos dessas essências (madeira, lenha, amêndoas, ceras, gomas, etc.)". A silvicultura é o segmento central da Cadeia Agroindustrial da Madeira, que também engloba todos os segmentos ofertantes de produtos à silvicultura e os segmentos processadores e distribuidores de produtos que na sua elaboração utilizam a madeira. A Cadeia Agroindustrial da Madeira, por sua vez, segundo a ASSOCIAÇÃO BRASILEIRA DE AGRIBUSINESS (1993), é uma das cadeias que formam o agribusiness brasileiro.

2 O plantio de florestas pode ser feito por florestamento ou reflorestamento, dependendo da composição vegetal original da região onde ocorre o plantio de árvores. 
LEITE (1979) fala sobre os beneficios diretos (palpáveis, que podem ser quantificados, como, por exemplo, a madeira) e os beneficios indiretos (inerentes à própria existência da floresta, como, por exemplo, a conservação do solo) que as florestas (nativas ou reflorestadas/florestadas) proporcionam. Este autor comenta, ainda, que a silvicultura é uma atividade extremamente dinâmica, pois está em constante mudança, alterando-se em função de princípios técnicos, de princípios econômicos, de circunstâncias políticas, de princípios ambientais, etc..

Segundo SIQUEIRA (1990), tanto as florestas nativas quanto as plantadas apresentam três funções básicas: a função de produção ${ }^{3} \mathrm{e}$ as funções de proteção ambiental e recreação. Ainda conforme SIQUEIRA (1990), a função de produção quase sempre existiu e somente à medida que a Humanidade foi despertando para as questões ambientais é que a silvicultura incorporou as duas outras funções.

Especificamente, podemos falar que a função de produção é a associação direta da floresta com o produto que ela gera ${ }^{4}$.

HOSOKAWA (1987, p.114) discute a função de proteção ambiental apresentada pelas florestas, dizendo que esta função está relacionada à proteção contra a erosão hídrica e eólica, à contribuição no equilibrio do micro clima, à contribuição no equilibrio hidrológico, à contribuição no equilíbrio atmosférico, à proteção contra a radioatividade, à proteção contra ruído, à proteção da fauna e da flora, etc..

${ }^{3}$ Neste caso, a expressão função de produção tem um significado específico para o contexto da silvicultura, não estando relacionada à convencional definição econômica de função de produção.

4 Tendo como enfoque a Cadeia Agroindustrial da Madeira como um todo, por exemplo, podemos, segundo SIQUEIRA (1990), citar os seguintes produtos obtidos das florestas: frutos (usados na produção de inseticidas, medicamentos, óleos), sementes (usadas na produção de alimentos, drogas, perfumes, aromatizantes, etc.), folhas (usadas na produção de tintas, sabão, etc.), cascas (utilizadas para produzir perfumes, medicamentos, etc.), resina (empregada na produção de gomas, tintas, vernizes, etc.). A partir da extração e industrialização da madeira, temos: madeira serrada e beneficiada, lâminas e compensados, aglomerados, chapas de fibras, papel (cartolina, para jornal, para revista, misto, kraft, para fins higiênicos, para embalagens, etc.), celulose, móveis e acessórios para a construção civil (estruturas, paredes, tacos, sacos multifoliados, etc.), dormentes, postes, cabos de vassoura, etc.. A madeira também pode gerar energia através da lenha e do carvão vegetal. Há, também, produtos obtidos a partir da destilação da madeira, como o metanol e a acetona. 
Detalhando um pouco mais esta função de proteção ambiental, podemos dizer que as áreas reflorestadas ou com florestas nativas estabilizam o solo e o protegem da erosão. Com o desenvolvimento da floresta, as raízes aprofundam-se no solo, retirando das camadas inferiores os nutrientes que, na continuidade do seu ciclo, retornam ao solo na forma de folhas, cascas e galhos, formando o "humus" pela decomposição destes resíduos vegetais. Isso tudo é de importância especial nos locais onde as plantações são estabelecidas em terras depauperadas e em processo de erosão, em lugares onde as florestas nativas foram exauridas ou destruídas e em terrenos de grandes inclinações e arenosos.

Nas áreas reflorestadas ou com florestas nativas, há uma melhor infiltração de água no solo e uma redução do fluxo de água na superfície proveniente das enxurradas. As florestas não eliminam as enchentes, mas ajudam a controlá-las, reduzindo as suas conseqüências. As florestas também podem estender e aumentar os fluxos de água durante a estação seca (fazendo a regularização das bacias hidrográficas).

Um outro aspecto importante é que com o desenvolvimento da silvicultura e, conseqüentemente, com o aumento da área reflorestada, tendem a diminuir as pressões pelo uso de matas nativas, ou o que sobra delas. Com isso, percebemos que as áreas reflorestadas protegem o ambiente de forma direta e indireta.

Quanto à função de recreação, HOSOKAWA (1987, p.114) diz que esta função está relacionada com atividades como piscicultura e caça; também está relacionada com uma contribuição na manutenção da arquitetura paisagística, na produção de recreação e turismo, na manutenção de sanidade fisica e mental do ser humano (através de um maior contato homem-natureza), etc..

Ainda sobre a importância da silvicultura, um outro aspecto a ser comentado é o relacionado à geração de empregos.

No IV ENCONTRO NACIONAL DE REFLORESTADORES (1978), encontramos informações que dizem que, em 1978, havia, seguramente, 300 mil brasileiros trabalhando na atividade silvicultora. Neste trabalho foi dito que esta atividade gerava, anualmente, cerca de 30 mil novos empregos em função das novas florestas que 
íam sendo implantadas. Ao mesmo tempo, criavam-se outros 30 mil empregos anuais na área de exploração de florestas que íam atingindo a maturidade.

REIS (1982, p.15)', citado por BACHA (1993, p.166), estimava que, em 1982, havia um total de 600 a 700 mil pessoas empregadas na silvicultura. Valores menores que estes foram encontrados por BACHA (1993) que, com base em dados do IBGE (Censos Agropecuários), afirmou existirem, em 31/12/1980, 95.691 pessoas ocupadas na silvicultura e, em 31/12/1985, 117.249 pessoas.

TOLEDO (1994) estima que a cada emprego gerado na silvicultura de São Paulo correspondam 4,40 empregos na indústria de madeira, mobiliário de madeira, papel e papelão, não estando agregados os empregos indiretos, como, por exemplo, os de transporte de madeira e derivados.

Para todo o Brasil, de acordo com BACHA (1995, p.81), em 31/12/1985, estavam ocupadas 746.526 pessoas na Cadeia Agroindustrial da Madeira (que engloba as atividades silvicultoras e industriais, comerciais e de serviços relacionadas à primeira). Neste mesmo momento, existiam 117.249 pessoas ocupadas na silvicultura. Assim, de acordo com o autor citado, para cada pessoa ocupada na silvicultura havia, em $31 / 12 / 1985,5,4$ pessoas ocupadas em atividades direta e indiretamente vinculadas à silvicultura.

Constatamos do exposto acima que, apesar da variação dos dados existentes, a expansão da silvicultura ocorrida no Brasil foi responsável por um aumento significativo na geração de empregos.

Um tópico bastante abordado na literatura a respeito da silvicultura no Brasil é a grande expansão da área reflorestada/florestada. Parte significativa desta expansão ocorreu devido aos incentivos fiscais concedidos pelo Governo Federal à atividade de reflorestamento/florestamento. Além disso, o reflorestamento/florestamento concentrouse em árvores dos gêneros Eucalyptus e Pinus.

5 REIS, M.S. (1982) "Política Florestal Brasileira" in Silvicultura, ano VII, no26, p. 14 a 20, São Paulo, Setembro-Outubro de 1982. 
De acordo com SIQUEIRA (1990, p.17), de 1967 a 1989, houve um total de 6.575.428 hectares de área reflorestada, sendo que, aproximadamente, $89 \%$ dessa área foi reflorestada com incentivos concedidos pelo Governo Federal. A maior parte das árvores plantadas foi com espécies de eucalipto e pinus.

Conforme o IV ENCONTRO NACIONAL DE REFLORESTADORES (1978), a área total plantada com recursos dos incentivos fiscais, no período de 1967 a 1977, foi de 2.524.879 hectares, sendo que a área reflorestada com o gênero Pinus foi de 959.238 hectares e a área reflorestada com o gênero Eucalyptus foi de 1.493 .093 hectares, ou seja, $38,0 \%$ e $59,1 \%$ do total da área reflorestada, respectivamente, totalizando estes dois gêneros $97,1 \%$ das árvores plantadas. A Região Sudeste, apesar de representar apenas 10,9\% da área de terras do Brasil (com 91.881 .000 hectares), foi responsável, neste período de 1967 a 1977 , por 1.412 .000 hectares de área reflorestada, o equivalente a $56 \%$ de todo o reflorestamento realizado no referido período.

Segundo TOLEDO (1994), a área reflorestada somente no Estado de São Paulo ocupava, em 1994, 1.028.000 hectares, dos quais estimava-se que 774.000 hectares estavam plantados com eucalipto e 254.000 hectares com pinus.

Segundo BACHA (1993), o ritmo de reflorestamento no Brasil, se comparado com a área ocupada com outras culturas, também foi elevado. A área reflorestada em 1975 era menor que a área colhida com algodão, arroz, feijão, milho, soja ou trigo. Em 1984, a área reflorestada era menor, somente, que a área colhida com milho ou com soja. Este fato demonstra a importância do reflorestamento sob o ponto de vista da ocupação do espaço rural.

Na década de 70, existiam autores (como FLANZEN, 1979) que alegavam que o Brasil possuía um dos maiores e mais bem sucedidos programas de reflorestamento do mundo. Os seus plantios anuais, citava este autor, em 1979, eram ultrapassados, em área, somente pela antiga União Soviética, pela China e pelos Estados Unidos.

AFONSO NETO (1986) diz que o desenvolvimento da silvicultura no Brasil colocou-o, em 1986, em quarto lugar no mundo em implantação de maciços florestais homogêneos. 
Analisando as causas dessa expansão da silvicultura, temos o trabalho de BACHA (1993, p. 136-138), que estimou uma equação da expansão da área reflorestada/florestada no Brasil. Nesta equação, este autor inclui variáveis como preço $\mathrm{da}$ madeira, incentivos do governo ao reflorestamento/florestamento $\mathrm{e}$ área reflorestada/florestada defasada ${ }^{6}$. Contudo, o citado autor não incorporou em sua equação da área reflorestada/florestada uma variável que captasse a evolução tecnológica ocorrida na silvicultura brasileira.

A importância dessa evolução tecnológica torna-se evidente quando, ao compararmos o nível tecnológico existente até o final da década de cinqüenta com o nível tecnológico atual, percebemos que as transformações tecnológicas ocorridas na silvicultura brasileira foram intensas e marcantes e coincidem com a expansão da área reflorestada/florestada. Assim, podemos levantar a suposição de que a evolução tecnológica pela qual passou a silvicultura brasileira - evolução esta que, aliás, continua ocorrendo - permitiu a obtenção de produtos florestais de uma forma muito mais eficiente. Este aumento da eficiência (quantificado, basicamente, pelo aumento da produtividade e provocando uma diminuição dos custos e, com isto, um aumento da lucratividade desta atividade) pode ter provocado um impacto positivo e direto sobre a expansão da área reflorestada/florestada, colaborando para o grande aumento dessa área.

Até hoje, apesar das grandes tranformações tecnológicas ocorridas na silvicultura, muito pouco foi realizado em termos de sua análise e nenhum estudo foi feito no que diz respeito à relação entre estas inovações e a expansão da área reflorestada/florestada. Um dos poucos trabalhos que discute as inovações tecnológicas ocorridas na silvicultura brasileira é o de TOLEDO (1994), que, por não tratar especificamente do assunto, faz apenas uma análise superficial.

Assim, como já colocado anteriormente, o objetivo deste trabalho é realizar uma análise das inovações tecnológicas ocorridas na silvicultura brasileira, bem como estudar os seus impactos sobre a expansão desta atividade.

6 BACHA (1993, p.136-138) estimou sua equação para o periodo de 1970 a 1985 , constatando que os preços da madeira de matas plantadas influenciaram o incremento de área reflorestada/florestada em maior intensidade que os incentivos fiscais; ficando em terceiro lugar a importância da área reflorestada/florestada defasada. 
Para chegarmos ao nosso objetivo desenvolvemos uma série de tópicos. No capitulo 1, analisamos as fases da silvicultura brasileira. No capítulo 2, estruturamos critérios de classificação das inovações tecnológicas (item 2.1) e comparamos os sistemas de produção iniciais com os atuais, tanto para o eucalipto quanto para o pinus, evidenciando os contrastes entre as tecnologias empregadas (item 2.2). Em seguida (item 2.3), analisamos a evolução das pesquisas e das inovações tecnológicas na silvicultura brasileira. No capítulo 3, estudamos a relação entre inovação tecnológica, produtividade e custo (item 3.1), desenvolvemos uma equação da área reflorestada (item 3.2) onde avaliamos o papel das inovações tecnológicas sobre a expansão da área reflorestada/florestada e testamos esta equação (item 3.3). Por último, apresentamos nossas conclusões (capítulo 4). 


\section{CAPítulO 1}

\section{A SILVICULTURA NO BRASIL}

O propósito deste capítulo é analisar, nos seus principais pontos, a história da silvicultura no Brasil, o que contribui para o entendimento do processo de evolução tecnológica ocorrido nesta atividade.

Seguindo LEITE (1979), podemos dizer que a sivicultura brasileira apresentou três fases. A primeira fase correspondeu ao período que vai do descobrimento do Brasil até o início dos incentivos fiscais ao reflorestamento/florestamento (em 1965). A segunda fase abrange $o$ período de vigência dos incentivos fiscais ao reflorestamento/florestamento (1966 a 1988). A terceira fase cobre o período pósincentivos fiscais ao reflorestamento/florestamento (de 1989 até hoje).

\section{1 - O Período Anterior aos Incentivos Fiscais Concedidos ao Reflorestamento/Florestamento}

Quando o Brasil foi descoberto, iniciou-se um processo de destruição de suas matas nativas, ocorrendo poucos reflorestamentos até 1965 . Durante todo esse período a nação assistiu, com relativa passividade, a esse processo. Tudo o que foi feito em termos de plantio e de reconstituição do nosso patrimônio florestal foi sempre muito pouco significativo diante do que tínhamos em termos de desmatamento.

Conforme SIQUEIRA (1990), a atividade florestal instalou-se no Brasil logo após o seu descobrimento, através da exploração do pau-brasil, que, por muito tempo, constituiu-se na principal atividade econômica aqui realizada. 
Até o início dos incentivos fiscais ao florestamento e reflorestamento (em 1965), tínhamos uma atividade florestal extrativista, nômade, que sempre caracterizou-se como antecessora de grandes ciclos econômicos nacionais, como é o caso, por exemplo, do café, da cana-de-açúcar e da própria pecuária, que sempre foram precedidos de um intenso desperdício de material lenhoso.

Segundo PEREIRA (1990), as primeiras décadas do presente século foram um período de crise e ao mesmo tempo de acontecimentos importantes (como, por exemplo, a introdução do eucalipto no Brasil) para o setor florestal brasileiro. Após longo tempo de intenso extrativismo, as matas de "madeiras duras", mais próximas dos centros consumidores, começavam a exaurir-se. As reservas de Araucaria angustifolia, única fonte viável de "madeira mole" e fibra longa do pais, já apresentavam igual tendência. Além do mais, o manejo sustentado das formações naturais e o cultivo de essências nativas em grande escala não se mostravam animadores.

Enquanto isso, prossegue PEREIRA (1990), a demanda por produtos florestais aumentava, já que a população começava a crescer a taxas maiores e a nação ensaiava os primeiros passos rumo à industrialização.

Neste período anterior à introdução dos incentivos fiscais, na dinamização do reflorestamento, tivemos, principalmente, esforços pioneiros na introdução de plantios homogêneos de eucalipto e pinus.

\subsection{1 - A Introdução da Eucaliptocultura no Brasil}

Segundo JOLY (1975), "o Eucalyptus, L'Héritr, é um gênero de plantas da família das Mirtáceas, da tribo das Leptospermeas, que conta com centenas de espécies e grande número de variedades e de híbridos".

Sobre o eucalipto, NAVARRO DE ANDRADE (1961) nos diz que a quase totalidade das espécies são indígenas da Austrália $^{7}$, inclusive da Tasmânia, onde

\footnotetext{
${ }^{7}$ Há exceções representadas por seis espécies (cinco das ilhas da Nova Guiné e Timor e uma das Molucas).
} 
formavam densas e vastas florestas, constituindo boa parte da riqueza florestal da Oceania. Muitas espécies de eucalipto apresentam dimensões gigantescas, havendo, porém, um grande número de outras, de porte mediano e arbustivo.

É dificil determinar, com segurança, a data exata de introdução do eucalipto no Brasil $^{8}$. Tal introdução ocorreu no século passado mas, segundo CIANCIULLI (1954), foi Edmundo Navarro de Andrade quem, no presente século, trouxe o maior número de espécies de eucalipto da Austrália para o Estado de São Paulo, e, conseqüentemente, para o Brasil como um todo.

GURGEL FILHO (1962) também salienta os esforços empreendidos por Edmundo Navarro de Andrade para o estabelecimento, no Brasil, da cultura racional do eucalipto. Contudo, o citado autor relembra as atividades técnicas e científicas desenvolvidas pelo Serviço Florestal do Estado de São Paulo no estabelecimento da eucaliptocultura.

Edmundo Navarro de Andrade, em 1903, logo após a sua formatura (ocorrida em Coimbra), ao regressar ao Brasil, foi convidado pelo então Presidente da Companhia Paulista de Estradas de Ferro, Conselheiro Antônio Prado, a assumir o cargo de Diretor do Horto de Jundiaí, onde iniciou, em 1904, os estudos comparativos do desenvolvimento de essências florestais indígenas e exóticas de valor econômico.

8 Tinha-se como certo que os primeiros exemplares de eucalipto tinham sido plantados no Rio Grande do Sul, em 1868. Porém, segundo Joaquim Antônio de Azevedo, no seu "Eucalyptus globulus", publicado no Rio de Janeiro, em 1874, foi o Coronel Felipe Belzebé de Oliveira Neri que, em 1865, remeteu, do Uruguai, as primeiras sementes de eucalipto, a vários amigos da então província São Pedro do Rio Grande do Sul.

Segundo NAVARRO DE ANDRADE (1961), embora seja dificil precisar a data de introdução do eucalipto no Brasil, parece que se pode afirmar que São Paulo o plantou antes de qualquer outro. Há dados da plantação de exemplares de eucalipto no período entre 1861 e 1863.

Segundo J. BARBOSA RODRIGUES (no seu "Hortus Fluminensis", publicado no Rio de Janeiro de 1894, em seu Resumo Histórico), Frei Leandro do Sacramento, diretor do Jardim Botânico de 1824 a 1829, fez ali plantar dois exemplares de Eucalyptus gigantea. Essas árvores constavam do Catálogo das Plantas Cultivadas do Jardim Botânico, que não chegou a ser publicado. Considerando esse fato, faz-se recuar a introdução do eucalipto, no Brasil, em mais de quarenta anos das datas assinaladas por qualquer outro autor. 
Nesse ensaio, o eucalipto avantajou-se de tal forma sobre as demais essências que a Companhia Paulista não teve dúvidas, e, ao adquirir mais terras, em 1909, em Rio Claro, optou pela opinião de Navarro de Andrade, intensificando a cultura do eucalipto.

Já em Rio Claro, em 1910, Navarro de Andrade plantava uma coleção de várias espécies de eucalipto e iniciava o trabalho de viveiros em maior escala, com 123 espécies das 144 que tentou introduzir em São Paulo.

Navarro de Andrade, como ele mesmo afirmou, não pretendeu resolver o problema do reflorestamento de São Paulo ou do Brasil com o eucalipto. Resolveu ele, apenas, o problema que the foi proposto e que era o de fornecer, rapidamente, combustível para as locomotivas da Companhia Paulista de Estradas de Ferro, e, também, madeira para postes, dormentes e outras aplicações.

O que aconteceu, no entanto, foi que os lavradores do Estado de São Paulo, desejando formar recursos florestais em suas propriedades e não tendo outras fontes de informações para orientar essas culturas, aproveitaram os ensinamentos de Navarro de Andrade e, assim sendo, o referido Estado tornou-se, com relação à silvicultura, um verdadeiro "Mar de eucaliptais", nas palavras de GURGEL FILHO (1962).

Em 1924, a Companhia Paulista de Estradas de Ferro possuía oito milhões de árvores de eucalipto plantadas em nove propriedades agrícolas, ao longo de suas linhas férreas e distribuídas de acordo com a necessidade de combustível.

Nessa época, teve início uma campanha contra o eucalipto (críticas sobre a qualidade da madeira, principalmente), coincidindo com um período de depressão econômica do Estado, o que levou a Companhia Paulista de Estradas de Ferro a suspender o plantio de novas glebas. Somente dez anos depois, em 1934, as plantações foram reiniciadas com a compra de novas propriedades, sendo, então, o plantio feito com tal intensidade que cinco anos depois, em 1939, o Serviço Florestal da Companhia Paulista de Estradas de Ferro já possuía dezenove milhões de árvores de eucalipto, mais que o dobro, portanto, das plantações efetuadas de 1904 a 1924.

Ao morrer, Edmundo Navarro de Andrade deixava plantadas, para a Companhia Paulista de Estradas de Ferro, vinte e quatro milhões de árvores de eucalipto. 
Segundo CIANCIULLI (1954), como resultado desse trabalho, "fruto" de anos de observação e experimentação, definiu-se no campo da silvicultura o lugar dessa "Mirtácea" como árvore para múltiplas aplicações nas atividades agrícolas, silviculturais, industriais e comerciais do nosso país.

\subsection{2 - A Introdução da Pinocultura no Brasil}

Segundo JOLY (1975) "o Pinus é um gênero de plantas da ordem das coníferas, família das Pináceas, que conta com cerca de 90 espécies".

Segundo PEREIRA (1990), as coníferas são, em sua maioria, espécies de regiões frias, onde constituem-se na principal ou, às vezes, na única fonte de produtos florestais para as nações. Para os habitantes dos trópicos e, talvez, em especial para os brasileiros, as coníferas sempre foram motivo de atração por serem diferentes das plantas tropicais comuns. Para os antigos imigrantes eram "um pedaço da Europa no Brasil". Por isso, desde cedo, todos que para cá se mudavam ou de lá retornavam procuravam trazer sementes e mudas para serem plantadas em jardins, parques e fazendas. Podemos dizer que eram introduções para fins decorativos as que foram feitas inicialmente.

Precisar a época em que se introduziu as primeiras coníferas exóticas no Brasil, prossegue PEREIRA (1990), é praticamente impossível. Porém, alguns autores afirmam que as primeiras sementes ou mudas teriam sido trazidas logo após a criação do Jardim Botânico do Rio de Janeiro, por D. João VI, no início do século XIX. Outros são da opinião de que isso teria sido feito posteriormente, por viajantes.

PEREIRA (1990) cita que uma informação mais ilustrativa e concreta seria a de ECHENIQUE (1940) ${ }^{9}$, que afirma conhecer grupos de Cryptomeria japonica plantadas em 1870 no município de Pelotas, Estado do Rio Grande do Sul, lugar onde existiam também vários exemplares de Pinus canariensis semeados em 1880, além de outras coníferas muito idosas.

9 ECHENIQUE, S. da C. (1940). Contribuição para o estudo das coníferas no Rio Grande do Sul. In: Congresso Riograndense de Agronomia, 2, Porto Alegre, p. 113-129, v.1. 
Para CIANCIULLI (1954), as maiores e mais importantes introduções de coniferas para fins ornamentais no Brasil devem ser atribuídas a Alberto Loefgren, diretor do antigo Horto Botânico de São Paulo. No início deste século, foram notáveis os trabalhos desenvolvidos por esse botânico sueco, sendo que um dos seus livros, "Notas Sobre as Plantas Exóticas Introduzidas no Estado de São Paulo", publicado em 1906, constitui um dos mais seguros pontos de referências para a determinação da época do aparecimento das principais plantas exóticas aqui aclimatadas. Para fins produtivos, podemos observar algumas experiências do setor privado e dos órgãos públicos, quanto à pinocultura, até a década de cinqüenta. Não obstante, a grande expansão da pinocultura no Brasil ocorre a partir do final da década de cinqüenta, isto devido à diminuição assustadora dos povoamentos nativos da nossa Araucaria angustifolia (PRATES, 1979).

PEREIRA (1990) diz que a primeira participação do setor privado no processo de introdução de coníferas no Brasil deve ser creditada à Companhia Paulista de Estradas de Ferro, isso no ano de 1904. As informações disponiveis indicam que a Companhia Paulista de Estradas de Ferro, apesar de ter optado pelo eucalipto como material principal em seus reflorestamentos (como vimos no item anterior), manteve interesse por outras espécies por muitos anos, entre as quais as coníferas. Em 1953, a citada Companhia chegou a instalar ensaios com coníferas em 9 hortos de sua propriedade.

PEREIRA (1990) também comenta que o setor público teve forte participação no processo de introdução de coniferas com fins silviculturais no Brasil. $\mathrm{O}$ órgão líder dessa importante tarefa foi o Serviço (hoje Instituto) Florestal do Estado de São Paulo, que, animado pelo sucesso dos programas de introdução conduzidos pela Austrália, Nova Zelândia, Argentina e outros países, realizou, em 1953, os primeiros ensaios com espécies de pinus em arboretos do Horto Florestal da Capital.

PEREIRA (1990), citando GUIMARÃES (1957) ${ }^{10}$, afirma que embora os experimentos tenham tido início em 1953, nessa época já havia espécies que mostravam desenvolvimento inicial promissor, mesmo em solos arenosos e pobres. Essas espécies

${ }^{10}$ GUIMARÃES, R.F. (1957). Plantio Experimental de Coniferas no interior do Estado de São Paulo. Jundiaí, CPEF, 20p., Boletim n ${ }^{\circ} 9$. 
eram: Pinus taeda, Pinus elliottii, Pinus patula, Pinus pinaster, Pinus oocarpa, Pinus radiata, Pinus montezumae e Cunninghamia lanceolata.

No final da década de cinqüenta e na década de sessenta, com a instalação de numerosas firmas ligadas à industrialização de madeira no país, as introduções de coníferas, e acima de tudo de pinus, aumentaram significativamente.

No IV ENCONTRO NACIONAL DE REFLORESTADORES (1978, p.34), encontramos informações que mostram que Pinus elliottii var elliottii e Pinus taeda, nos idos de 1958, já estavam sendo estabelecidos em plantios com escala comercial, no Brasil. Continua o trabalho dizendo que foi somente a partir de 1963, após as grandes secas e incêndios florestais do Sul, que o Pinus caribaea e o Pinus oocarpa ganharam destaque.

Por volta de 1968 o IPEF - Instituto de Pesquisas Florestais da Universidade de São Paulo - iniciou um amplo programa de estudos de procedências de pinus na região Sul, em associação com várias empresas, o qual contribuiu para a racionalização das introduções e dos plantios destas árvores nos Estados do Paraná e de Santa Catarina.

Quanto aos tipos de pinus plantados até a década de sessenta, podemos dizer que, em geral, primeiro foram introduzidas quase somente espécies de clima temperado, sendo que só mais tarde iniciou-se a introdução de coníferas com procedência tropical.

\section{$1.2 \quad-\quad 0 \quad$ Período dos Incentivos Fiscais Concedidos ao Reflorestamento/Florestamento}

Com o início dos incentivos fiscais ao reflorestamento, passamos para outra fase na evolução da silvicultura brasileira. Nesta fase, houve o aumento da atividade empresarial na silvicultura, o aumento do número de profissionais vinculados à silvicultura e grande evolução da ciência florestal no Brasil.

$\mathrm{Na}$ década de 60 do presente século, quando o setor florestal passou a ser tratado com maior atenção, houve a criação do Instituto Brasileiro de Desenvolvimento Florestal (IBDF), atual Instituto Brasileiro do Meio Ambiente e Recursos Naturais Renováveis (IBAMA); houve o surgimento das primeiras escolas de Engenharia Florestal no Brasil e 
houve a implementação de facilidades fiscais que tornaram o reflorestamento uma operação de larga escala.

Comentemos, um pouco, os efeitos dessas facilidades fiscais.

Segundo BACHA (1993), existem dois mecanismos básicos para incentivar o reflorestamento: o primeiro é a elevação do custo de extração de toras provenientes de matas nativas e o segundo é a concessão de incentivos monetários ao plantio (como o crédito subsidiado, o incentivo fiscal e a doação de insumos), sendo que esses incentivos atuam como redutores do custo de implantação da floresta homogênea.

Na 1a metade da década de 60, nos diz BACHA (1993, p.112), "já ocorria a utilização de incentivos fiscais para dinamizar atividades econômicas que diminuíssem as disparidades regionais. Por isso, para impulsionar o reflorestamento, foi escolhida, inicialmente, uma política de incentivos fiscais, que vigorou de 1965 a 1988. Na segunda metade da década de 70 , quando já era bem difundida a política de crédito subsidiado para dinamizar vários setores (entre eles o agropecuário), foi instituído um programa de crédito subsidiado para o plantio de árvores em pequenos e médios imóveis rurais (o REPEMIR). Na segunda metade da década de 80 , quando se procurava ser mais rigoroso com os gastos públicos, realizou-se um programa de plantio de algarobeiras, na área da SUDENE, com base na doação de insumos".

De acordo com BACHA (1993, p.112), denominamos de Programa de Incentivos Fiscais ao Florestamento e Reflorestamento "o conjunto de atos normativos de origem federal (leis, decretos-lei, decretos e portarias) que, elaborados no período de 1965 a 1988, instituíram e regulamentaram os incentivos fiscais a essa atividade".

Os incentivos fiscais ao reflorestamento/florestamento consistiam em uma pessoa fisica ou jurídica abater de sua renda tributável ou do imposto de renda a pagar, respectivamente, parcelas que seriam destinadas a projetos de reflorestamento/florestamento. Estes projetos poderiam pertencer à própria pessoa optante do desconto do imposto de renda (caso dos projetos próprios) ou serem projetos de propriedade de terceiros (projetos comuns) dos quais o contribuinte-optante recebia títulos de participação (como o Certificado de Participação em Reflorestamentos). 
Com a criação do Programa de Incentivos Fiscais ao Florestamento e Reflorestamento, percebemos que houve, a partir de 1967, uma grande expansão da área reflorestada no Brasil, que saltou de quase 500 mil hectares em 1964 para 5,9 milhões de hectares em 1984 (BACHA, 1992a). Contudo, é importante ressaltar que tal expansão não se deveu apenas ao Programa de Incentivos Fiscais, mas também a outros programas públicos federais (caso do REPEMIR) e estaduais e ao plantio privado não incentivado pelo governo. Outro elemento que incentivou o reflorestamento/florestamento foi a demanda criada pelo Programa Nacional de Papel e Celulose, pelo Programa de Siderurgia a Carvão Vegetal e pelo Programa de Substituição Energética.

BACHA (1995) mostra que no período de 1968 a 1988 foram concedidos 7.046,04 milhões de dólares (a preços de dezembro de 1992) como incentivos fiscais ao reflorestamento/florestamento, que deveriam ter viabilizado o total de 6.217 .723 hectares de área reflorestada/florestada. $\mathrm{O}$ citado autor ainda demonstra, através de uma análise custo-beneficio baseada no excedente econômico, que o Programa de Incentivos Fiscais ao Reflorestamento/Florestamento teve um custo social mínimo de 386,44 cruzados por cada 1,00 cruzado de benefício social (valores em cruzados de março de 1986). Além disso, a literatura existente cita vários casos de fraudes no plantio (caso de empresas que tomaram os recursos e não fizeram a totalidade de reflorestamentos correspondentes) e plantios mal realizados (tanto no aspecto técnico como no econômico).

De acordo com o IV ENCONTRO NACIONAL DE REFLORESTADORES (1978), verificamos que dois foram os gêneros botânicos que se destacaram em área plantada durante o período de vigência dos incentivos fiscais ao reflorestamento/florestamento: o pinus e o eucalyptus" .

Conforme BACHA (1993) nos mostra, o reflorestamento concentrou-se em Minas Gerais, São Paulo, Paraná, Santa Catarina, Rio Grande do Sul e Mato Grosso. Esses 6

11 Os pinus representados pelo Pinus elliottii var elliottii, Pinus taeda e Pinus patula, mais disseminados na região Sul e o Pinus caribaea var. hondurensis e Pinus oocarpa nas regiões de clima quente. Os eucaliptos representados pelo Eucalyptus saligna, Eucalyptus grandis, Eucalyptus urophilla, Eucalyptus tereticornis, Eucalyptus robusta, Eucalyptus citriodora e outras espécies com menor participação. 
Estados tinham $97,33 \%$ das árvores plantadas existentes em $31 / 12 / 70$ e $88,76 \%$ em $31 / 12 / 85$.

A concentração do reflorestamento nos Estados de Minas Gerais, São Paulo, Paraná, Santa Catarina e Rio Grande do Sul ocorreu porque neles localiza-se a maior parte das grandes empresas consumidoras de matéria-prima florestal (siderurgia a carvão vegetal, indústrias de cimento, indústrias de celulose e outras), há reduzida magnitude de áreas com florestas nativas possíveis de serem utilizadas e maior facilidade para que a legislação florestal seja imposta, a qual obriga a reposição florestal por parte dos consumidores de matéria-prima florestal e o auto-abastecimento desses insumos por parte dos grandes consumidores.

O reflorestamento no Estado do Mato Grosso do Sul, prossegue BACHA (1993), ocorreu pelo fato desse estado estar situado bem próximo a Minas Gerais e a São Paulo e por possuir, no momento em que se realizou o reflorestamento, terras a preços inferiores a esses dois estados.

Além dessa concentração em poucos Estados, o reflorestamento concentrou-se em certas áreas dentro deles, formando "manchas" de florestas homogêneas.

Não obstante os elevados gastos com o programa de incentivos fiscais ao reflorestamento/florestamento em relação aos seus retornos, as fraudes ocorridas, os plantios mal conduzidos e a concentração regional das matas plantadas, foi durante o periodo do mencionado programa (1966 a 1988) que ocorreu a formação da silvicultura moderna no Brasil, com impactos sobre as pesquisas, pois $1 \%$ dos recursos alocados como incentivos fiscais ao reflorestamento/florestamento foi utilizado para financiar a pesquisa silvicultural. 


\section{3 - O Período Posterior aos Incentivos Fiscais Concedidos ao Reflorestamento/Florestamento}

Com o fim dos incentivos fiscais concedidos ao reflorestamento/florestamento (ocorrido em 1988) teve início a terceira fase na evolução da silvicultura brasileira. Neste período (de 1989 até hoje), as grandes empresas consumidoras de matéria-prima florestal dedicaram-se a reorganizar os seus maciços florestais objetivando reduzir custos e incrementaram, com o apoio de governos estaduais, programas de incentivo ao reflorestamento em pequenos e médios imóveis rurais.

As grandes firmas consumidoras de matéria-prima florestal (principalmente as da indústria de papel e celulose e da indústria siderúrgica a carvão vegetal) ampliaram sua área reflorestada/florestada com recursos próprios ou tomando empréstimos de longo prazo em bancos de fomento estaduais ou federais (caso do BADEP e BNDES).

$\mathrm{Na}$ ausência de informações sobre a área total reflorestada/florestada no Brasil neste período pós-incentivos fiscais ao florestamento e reflorestamento, construímos a Tabela 1 com base nos dados sobre a área reflorestada/florestada pelas empresas siderúrgicas a carvão vegetal e de papel e celulose que, devido à importância que apresentam dentro do contexto florestal brasileiro, podem servir de base para generalizações. Também na Tabela 1 , temos dados de área reflorestada/florestada em pequenos imóveis rurais em Minas Gerais através do Programa Fazendeiro Florestal. 
TABELA 1 - ÁREA REFLORESTADA/FLORESTADA NO BRASIL POR CERTOS GRUPOS (em hectares)

\begin{tabular}{c|c|c|c}
\hline Ano & $\begin{array}{c}\text { Indústria de Papel } \\
\text { e Celulose* }\end{array}$ & $\begin{array}{c}\text { Indústria } \\
\text { Siderúrgica a } \\
\text { Carvão Vegetal }\end{array}$ & $\begin{array}{c}\text { Pequenos e Médios Imóveis } \\
\text { Rurais em Programa Estadual } \\
\text { ou com Empresas- MG }\end{array}$ \\
\hline 1982 & $77.503,0$ & - & - \\
\hline 1983 & $65.403,0$ & - & - \\
\hline 1984 & $77.295,0$ & - & - \\
\hline 1985 & $83.282,0$ & - & - \\
\hline 1986 & $81.597,0$ & - & - \\
\hline 1987 & $88.370,0$ & 58.488 & - \\
\hline 1988 & $102.054,0$ & 54.352 & 3.374 \\
\hline 1989 & $118.050,0$ & 88.357 & 9.989 \\
\hline 1990 & $122.562,0$ & 125.000 & 12.378 \\
\hline 1991 & $82.253,4$ & 51.305 & 13.244 \\
\hline 1992 & $84.756,9$ & 80.067 & 7.564 \\
\hline 1993 & $89.424,5$ & 46.653 & 6.502 \\
\hline 1994 & & 37.026 & \\
\hline
\end{tabular}

FONTES: ANUÁRIO ESTATISTICO DA ANFPC (1982 a 1994)

ANUÁRIO ESTATÍSTICO DA ABRACAVE (1994)

* NOTA: Os dados anuais sobre a área reflorestada/florestada pela indústria de Papel e Celulose foram obtidos considerando-se os maiores valores (para o período de 1982 a 1993) da área reflorestada/florestada e ainda existente em cada ano.

Através da Tabela 1, percebemos que a área reflorestada anualmente pela indústria siderúrgica a carvão vegetal, de forma geral, aumentou até o ano de 1990, quando atingiu 125.000 ha. Segundo a ABRACAVE (1994), apesar do abalo provocado pelo fim dos incentivos fiscais, ocorrido em 1988, o aumento da área reflorestada/florestada pala indústria Siderúrgica a Carvão Vegetal verificado nos anos de 1989 e 1990 foi devido, principalmente, à vitalidade das empresas industriais consumidoras de carvão vegetal e ao investimento em pesquisa feito pelo setor privado (em articulação com as Universidades), que resultaram numa melhor produtividade das florestas plantadas.

Já a tendência geral de diminuição da área reflorestada/florestada verificada na Indústria Siderúrgica a Carvão Vegetal no período de 1991 a 1994 pode ser explicada pela queda no consumo de carvão vegetal - que por sua vez, foi provocada pela recessão que havia no Brasil nos três primeiros anos da década da noventa, bem como pela 
redução do preço do coque mineral em relação ao carvão vegetal (que são produtos substitutos).

A área reflorestada/florestada anualmente com eucalipto e pinus pela indústria de papel e celulose, de forma geral, também apresentou um crescimento até o ano de 1990, quando atingiu 122.562,0 hectares. Em 1991, ocorreu uma queda na área reflorestada/florestada (que foi de 82.253,4 hectares neste ano), havendo uma aparente retomada do crescimento nos anos de 1992 e 1993.

A Tabela 1 também mostra a crescente participação do reflorestamento em pequenos e médios imóveis rurais em Minas Gerais. Esse reflorestamento foi incentivado por empresas siderúrgicas ou de celulose e por programas estaduais. Trata-se de um mecanismo interessante de se promover a expansão da silvicultura com menor impacto sobre a posse da terra em relação ao que ocorre quando grandes empresas estabelecem seus próprios maciços florestais plantados.

A análise dos dados da Tabela 1 sobre as áreas reflorestadas/florestadas por alguns segmentos evidencia a existência de outros fatores - além dos incentivos fiscais que influenciam a taxa anual de reflorestamento/florestamento. Isto pode ser comprovado, principalmente, pelo fato de que mesmo com o final dos incentivos fiscais ao reflorestamento/florestamento, ocorrido em 1988, continuou havendo um crescimento da área reflorestada/florestada nos anos imediatamente seguintes (anos de 1989 e 1990).

BERGER (1979) reforça esta nossa suposição dizendo que não ocorreu, até 1979, uma perfeita correlação entre mudanças no oferecimento de incentivos fiscais e taxas anuais de reflorestamento. Entre os fatores que poderiam influenciar a área reflorestada/florestada, temos: o preço de mercado dos produtos oriundos da floresta, o preço dos insumos e dos fatores de produção e os beneficios das inovações tecnológicas, sendo que com o final dos incentivos fiscais ao reflorestamento/florestamento, estes fatores podem ter assumido uma maior importância.

Com o final dos incentivos fiscais, em 1988, percebemos o início da estruturação de um novo modelo de desenvolvimento da atividade florestal. Entre as possíveis características desse novo modelo, podemos citar: a valorização de aspectos como pesquisa e desenvolvimento tecnológico visando reduções nos custos de produção e 
melhorias nos níveis de produtividade os quais proporcionariam uma maior competitividade no mercado; a descentralização da atividade florestal (através, por exemplo, de um maior envolvimento de segmentos da estrutura de poder local e participação de sistemas cooperativos) por meio de programas com o objetivo de apoiar a realização de reflorestamento/florestamento em pequenos imóveis rurais.

No capítulo 2 do presente trabalho, vamos analisar as pesquisas e as inovações tecnológicas ocorridas na silvicultura brasileira, com o propósito principal de avaliar a sua importância para a expansão da área reflorestada/florestada. 


\section{CAPÍTULO 2}

\section{EVOLUÇÃo TECNOLÓGICA NA SILVICULTURA BRASILEIRA}

O propósito deste capítulo é analisar o processo de evolução tecnológica pelo qual passou, e continua passando, a silvicultura brasileira. Para isto, vamos nos concentrar, como já dito anteriormente, por sua importância e representatividade, no exame da Eucaliptocultura e da Pinocultura.

Inicialmente, são discutidos os critérios pelos quais as inovações tecnológicas são classificadas (item 2.1). Logo em seguida, são contrastados e comparados dois sistemas de produção, tanto para o eucalipto quanto para o pinus: o que foi utilizado inicialmente, de uma tecnologia simples e primária; e o atual, que já incorpora todas as inovações ocorridas neste período que os separa (item 2.2). Tal distinção favorece a compreensão do que ocorreu, em termos de inovações tecnológicas.

Levando em consideração o fato de que os trabalhos de pesquisa geram novas propostas, que por sua vez só poderão ser consideradas inovações tecnológicas se forem realmente absorvidas pelos sistemas de produção, dedicamos o último item deste capítulo (item 2.3) para analisar, com auxilio dos itens 2.1 e 2.2 , as pesquisas e as inovações tecnológicas ocorridas na silvicultura brasileira, bem como as relações que guardam entre si. 


\section{1 - Critérios de Classificação das Inovações Tecnológicas}

Existem poucos conceitos e categorias analíticas para tratar a inovação tecnológica na silvicultura. Segundo BACHA (1992b, p.42-43), "Revendo a literatura sobre inovação tecnológica nos setores agrícola e industrial, constatamos que foram desenvolvidos conceitos e categorias analíticas para esse último, mas que não foram considerados no caso do setor agrícola".

Com base no trabalho de BACHA (1992b) e realizando algumas modificações, pretendemos, neste item, estruturar um tipo de classificação para as inovações na silvicultura brasileira - que, aliás, pode ser estendida para outras áreas do setor agrícola nacional - utilizando as categorias de análise dos estudos de economia da tecnologia do setor industrial, e também levando em consideração as características próprias da silvicultura brasileira e até mesmo da agricultura como um todo.

De JANVRY (1973, p. 415-417) classificou as tecnologias agrícolas em quatro categorias: mecânica, biológica, química e agronômica. Verificamos a necessidade de incluirmos uma quinta categoria, que denominamos gerencial. Isto porque observamos uma série de inovações (que se relacionam mais à área administrativa, à área de tomada de decisão, à área de controle de qualidade, etc.) que não se enquadram em nenhuma das quatros categorias anteriores. Este será o nosso primeiro critério de classificação.

Uma nova máquina ou implemento desenvolvido para uma dada cultura, para uma operação específica ou até mesmo para a agricultura como um todo é considerado inovação mecânica. Também o uso de uma máquina ou implemento, já existente no mercado, em novas culturas ou operações, ou seja, onde antes não havia sido utilizado, é considerado uma inovação mecânica.

Em geral, as inovações mecânicas aumentam a produtividade do trabalho, pois aumentam a quantidade de terra cultivada por trabalhador em um mesmo período.

A literatura entende a inovação biológica como sendo o desenvolvimento de novas variedades e cultivares de plantas, novas raças e linhagens de animais, etc.. No nosso trabalho, consideraremos que toda e qualquer ação que direta ou indiretamente, nãointencional ou intencionalmente, acabe contribuindo para a seleção de indivíduos e, 
conseqüentemente, para o melhoramento genético de plantas e animais seja, também, uma inovação biológica. Assim, serão inovações biológicas: a introdução de uma espécie, já utilizada em outros locais, em uma nova área; os testes de procedência para verificação das espécies mais aptas a desenvolverem-se em determinadas áreas, sob determinadas condições ambientais, de fertilidade do solo, de manejo, etc.; os ensaios de competição entre diferentes espécies e os ensaios de competição entre progênies de uma mesma espécie (chamados testes de progênies) que contribuam para o melhoramento genético; os trabalhos de obtenção de híbridos resistentes às pragas e doenças; etc.

As inovações químicas correspondem à utilização, em uma cultura específica ou na agricultura como um todo, de adubos e corretivos, inseticidas, pesticidas, herbicidas, etc. (ou mesmo novas fórmulas, novas combinações desses produtos). Como nas inovações mecânicas, incluem-se entre as inovações químicas os novos produtos desenvolvidos, bem como o uso de produtos já existentes em situações novas. As inovações químicas intensificam o uso de capital e/ou trabalho por unidade de área explorada.

As inovações agronômicas são as novas práticas culturais, as novas técnicas de produção, as novas formas de se conduzir uma cultura, etc.. Dentre essas inovações, podemos citar: a introdução de rotação de culturas e a introdução de consorciação de culturas (se esses dois processos já foram implantados, uma nova combinação de culturas a serem rotacionadas ou consorciadas já é considerada uma inovação agronômica), introdução da análise de solo, novo calendário de operações, novos espaçamentos, etc.

Os aumentos da área reflorestada, da criação e adoção de novas tecnologias, da produtividade, da complexidade das relações e operações que envolvem a produção e a comercialização, da necessidade de rápidas atitudes face à competitividade do mercado, das exigências para a proteção ambiental, da necessidade de controlar custos e melhorar a qualidade do produto $\mathrm{e}$ das condições de trabalho, entre outros, provocaram $o$ surgimento da necessidade de um controle mais eficaz do processo de produção, de uma visão mais abrangente, mas ao mesmo tempo mais detalhada de todos os componentes, sua intra e inter-relações, seus problemas, custos, vantagens, etc.. Por causa disso, vem ocorrendo uma série de inovações na área administrativa, nas áreas de coleta e análise de 
dados, nas tentativas de otimizar e racionalizar as tomadas de decisão, etc.. A essas inovações daremos o nome de gerenciais. Elas podem ser: a informatização de operações, um novo arranjo de pessoal, o desenvolvimento de programas computacionais a serem usados na silvicultura, técnicas de racionalização e otimização de atividades, novos sistemas de coleta de dados, etc..

Prosseguindo com nossos critérios, observamos que as inovações que ocorrem na agricultura são, a exemplo da indústria, inovações de processos ou de produtos (BACHA, 1992b, p. 43-44). Este é o nosso segundo critério de classificação.

A inovações de processo correspondem às novas formas, novas maneiras de se chegar a um objetivo, isto sem a introdução de produtos diferentes. Caso se introduza um produto ainda não utilizado, teremos, então, a inovação de produto.

As inovações químicas, mecânicas e biológicas são, na sua maioria, inovações de produto. Aumentam a produtividade pela introdução de um novo produto, não importando que este produto seja novo somente para aquela situação, sob aquelas condições. Já as inovações agronômicas e as gerenciais são inovações de processo.

O nosso próximo critério (terceiro critério) é classificarmos as inovações tecnológicas em grandes inovações e em pequenas inovações. Podemos dizer que as grandes inovações são aquelas que afastam o sistema do seu equilíbrio, criam novas trajetórias, abrem espaços, definem paradigmas (ARAÚJO, 1989, p.9). Em última análise, podemos dizer que as grandes inovações são aquelas que provocam grandes aumentos na produtividade $^{12}$. As pequenas inovações alteram pouco a produtividade. Elas são mais os ajustamentos do sistema frente às grandes mudanças provocadas pelas grandes inovações tecnológicas.

Para SCHUMPETER (1939) ${ }^{13}$, citado por SILVA (1992), as grandes inovações são importantes para operar mudanças no processo econômico. As inovações menores refletem apenas as reações dentro dos limites do sistema.

12 Consideramos, para efeito de análise, que o aumento da produtividade leva a reduções no custo unitário de produção e, assim, a aumentos na lucratividade.

13 SCHUMPETER, J.A. (1939) "Business cycles: a theoretical, historical and statistical analysis of capitalist process". New York, McGraw-Hill, 2v., 1939. 
É importante salientar que a produtividade à qual nos referimos pode comportar uma série de definições, ou seja, quando falamos em produtividade decorrente de uma inovação tecnológica poderemos estar mencionando a produtividade de uma cultura (produção por área, estéreos/ha/ano, por exemplo), a produtividade de uma operação (número de hectares colhidos por dia, por exemplo), etc.. No Capítulo 3, encontra-se a evolução anual da produtividade para a silvicultura brasileira.

As inovações mecânicas, biológicas, químicas, agronômicas e gerenciais, tanto as de processo quanto as de produto, podem ser classificadas como grandes ou pequenas inovações, dependendo de seu efeito sobre a produtividade.

O quarto critério de classificação é o de separarmos as inovações tecnológicas em importadas e nacionais. Consideraremos uma inovação tecnológica importada aquela criada ou desenvolvida fora do Brasil e que chega até aqui através de algum processo de difusão de tecnologia. Quando ocorre o contrário, isto é, quando a inovação for aqui desenvolvida, daremos o nome de inovação tecnológica nacional. 


\section{2 - Comparação de Sistemas de Produção Passados e Atuais na Eucaliptocultura e na Pinocultura}

Pretendemos comparar os sistemas de produção através dos quais o eucalipto e o pinus eram cultivados no início de sua produção em maior escala no Brasil (década de cinquienta) com os sistemas atuais, os quais incorporam toda uma gama de inovações ocorridas neste período de tempo. Isto é feito através da colocação, e posterior discussão, de quadros comparativos dos sistemas de produção inicial e atual - tanto para o eucalipto quanto para o pinus.

No Quadro 1, temos os sistemas de produção inicial e atual de eucalipto e no Quadro 2 temos estes mesmos sistemas para o pinus. Os sistemas de produção dos Quadros 1 e 2 são, na verdade, sistemas indicados e exequíveis para as condições existentes.

É importante relembrar que a introdução em larga escala do pinus, no Brasil, foi mais tardia que a introdução do eucalipto (como destacado no capítulo 1), motivo pelo qual os sistemas de produção passado e atual desse gênero Pinus poderão apresentar contrastes menos marcantes. Aliado a isto está o fato de que há muitas similaridades entre os sistemas de produção desses dois gêneros, o que nos leva a unificar a discussão para evitar repetições. 


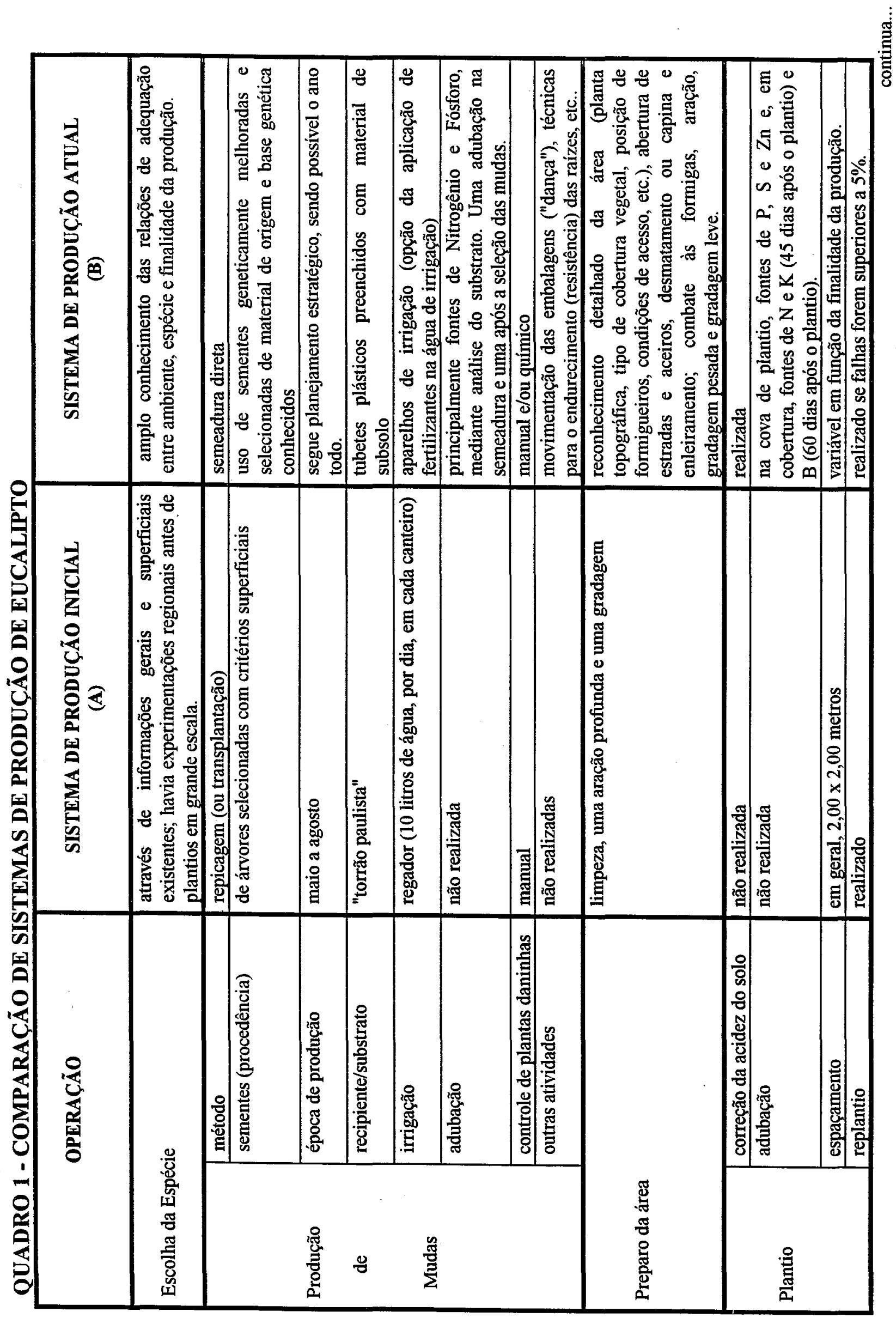




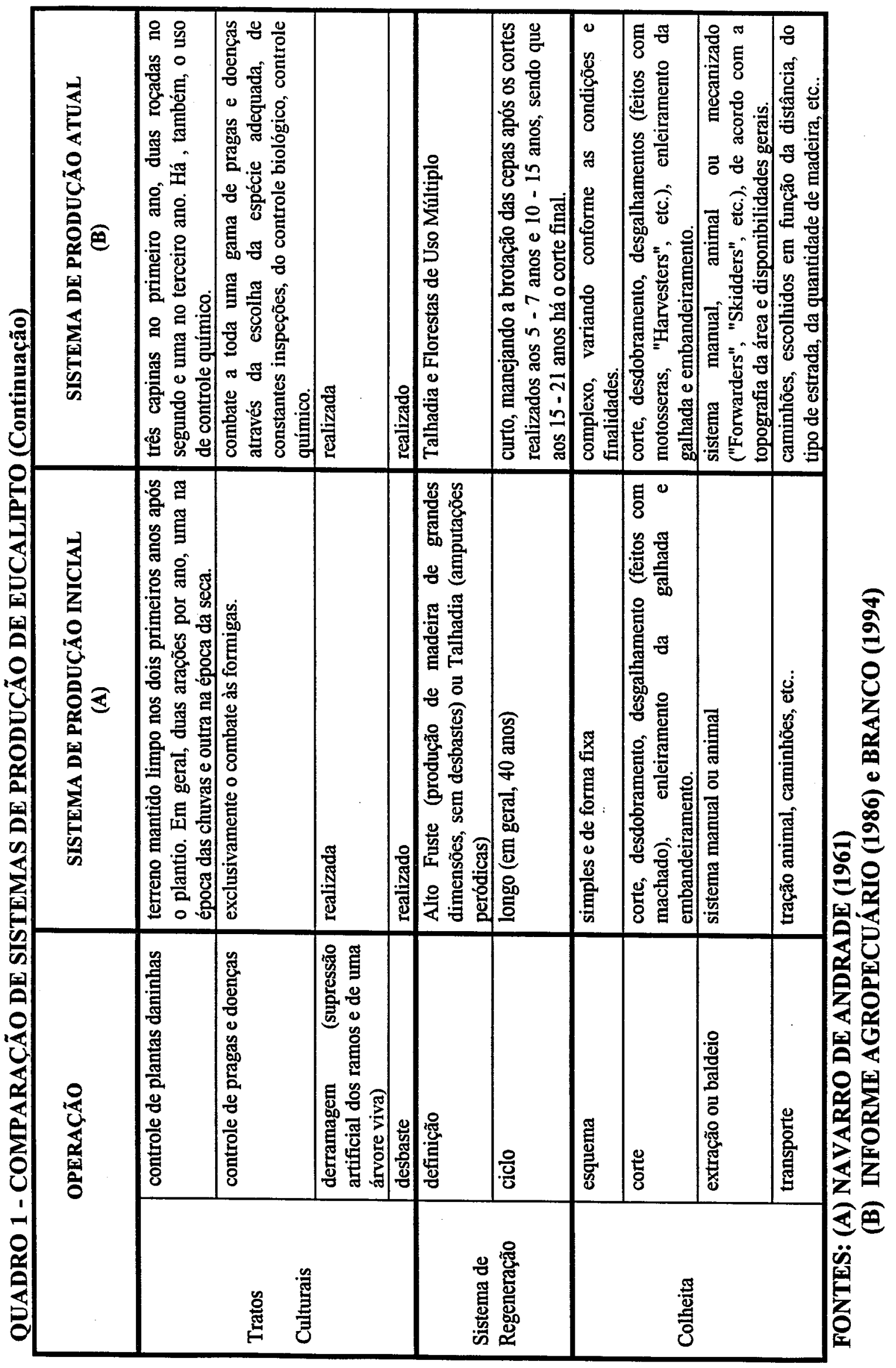




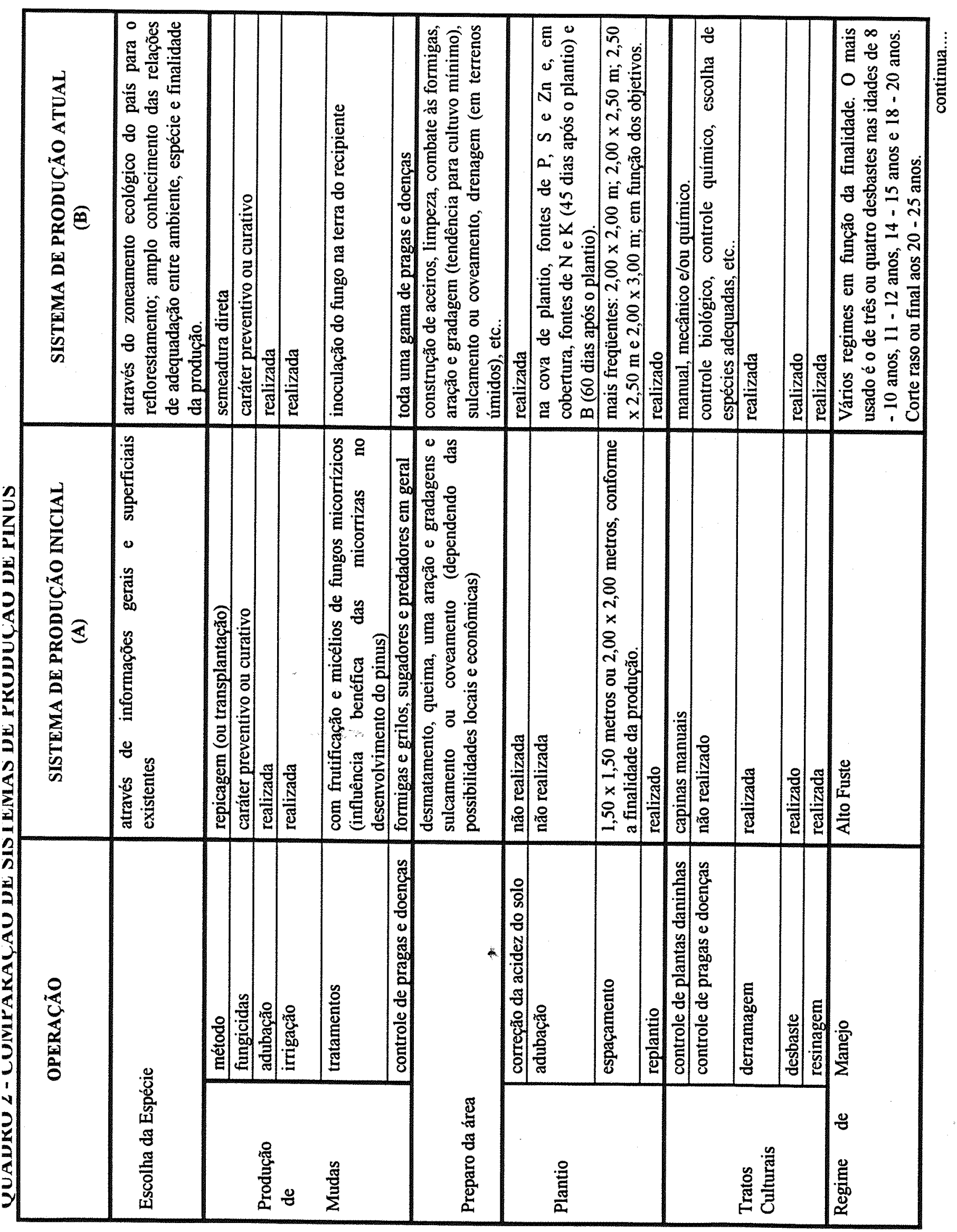




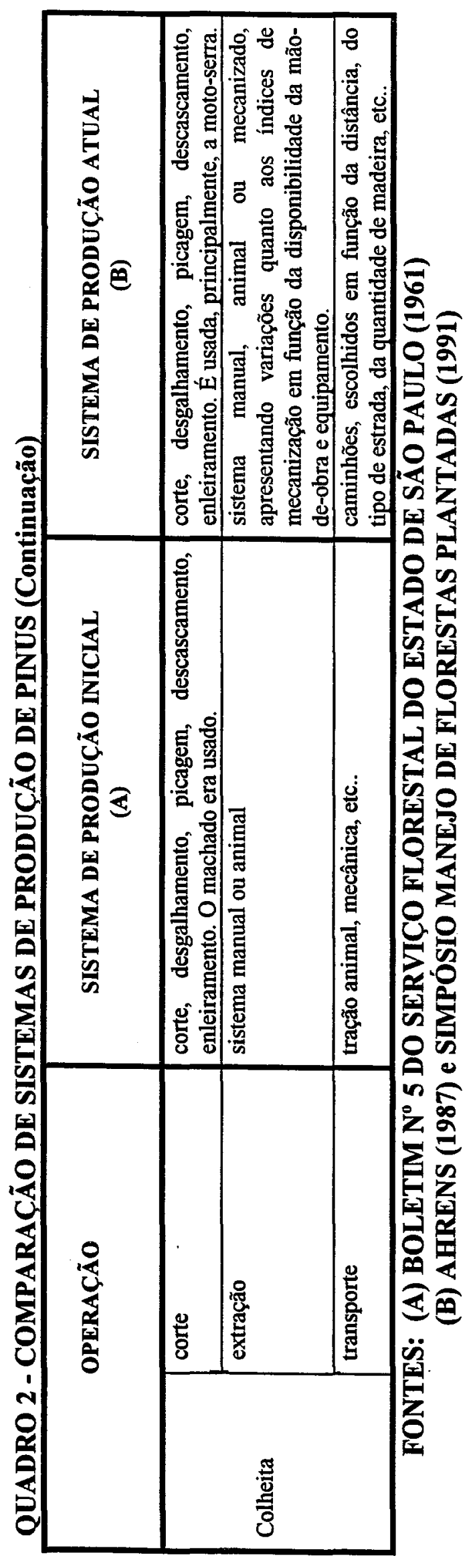


De forma geral, comparando os sistemas de produção, percebemos que houve grandes transformações nas últimas quatro décadas. Atualmente, busca-se um controle eficaz das operações, procura-se a qualidade total, há desenvolvimento nas áreas de coleta e análise de dados, há um grande horizonte de planejamento prévio, etc.. aspectos estes que não eram verificados no sistema de produção inicial.

A escolha da espécie para o plantio - que no início era feita de forma superficial passou a ser realizada de forma racional, técnica, embasada numa série de informações comprovadas. Assim, hoje, através de um zoneamento ecológico do Pais, sabemos quais as espécies aconselháveis para cada região específica. Além disso, também possuímos informações a respeito das espécies recomendadas para as mais variadas finalidades de produção (por exemplo: para a produção de papel e celulose temos o Eucalyptus grandis, o Eucalyptus saligna e o Eucalyptus urophylla; para a produção de madeira para mourões de cercas temos o Eucalyptus citriodora, o Eucalyptus robusta, o Eucalyptus paniculata e o Eucalyptus maculata, etc..)

A produção de mudas, no sistema inicial, era realizada através do método da repicagem - semeadura em canteiros apropriados e posterior transplantação das melhores mudas para embalagens individuais. O tipo de embalagem mais usado era o "torrão paulista" (confeccionado por uma prensa numa mistura de terra, areia e matériaorgânica). Não se adubavam as mudas e o controle de plantas daninhas era feito manualmente. Em geral, a produção de mudas era um processo relativamente simples e vagaroso. Hoje, no método utilizado para a produção de mudas, eliminou-se a fase dos canteiros, ou seja, temos o método da semeadura direta em recipientes - sacos plásticos ou, principalmente, tubetes de plástico rígido - preenchidos com material de subsolo (ou vermiculita, ou misturas de composto orgânico com moinha de carvão, etc..)

Hoje, na produção de mudas, há modernos sistemas de irrigação, realiza-se a adubação, e o controle de plantas daninhas, bem como o controle de pragas e doenças pode ser feito através de produtos químicos. Além disso, há uma série de técnicas visando uma produção de mudas mais resistentes. Assim, a produção de mudas passou a ser um processo eficiente, rápido e econômico. 
Quanto ao preparo da área, apesar do pinus não ser tão exigente quanto o eucalipto, esta operação ganhou muita importância no sistema de produção atual. As etapas de limpeza (queimadas, geralmente), aração e gradagem, deram lugar a um completo e bem elaborado programa de preparo do solo. Hoje, há, também, a realização do plantio direto.

Atualmente, realiza-se a gessagem, a calagem e a adubação do solo para o plantio, o que não era comum no sistema de produção inicial. Antigamente, usava-se o espaçamento de forma fixa, bem diferente do que ocorre hoje, quando o espaçamento varia em função da finalidade da produção (por exemplo: para o eucalipto, usa-se o espaçamento de 2,0 × 2,0 m, em ciclo de corte de 5 a 6 anos, se a finalidade da madeira é para lenha, carvão, etc.; usa-se o espaçamento de $3,0 \times 2,0 \mathrm{~m}$, em ciclo de corte de 7 a 9 anos, se a finalidade da madeira é para celulose, postes, vigas, serraria, etc..).

Quanto aos tratos culturais, podemos dizer que houve grandes transformações no controle de pragas e doenças e no controle de plantas daninhas. Atualmente, há amplos conhecimentos sobre pragas e doenças que causam danos de importância econômica. Conhece-se, por exemplo, pragas de viveiro (grilo, cupim, etc.), pragas de raízes (cupim subterrâneo), pragas de tronco (serrada, cupim, etc.) e pragas de folhas (lagartas, formigas, etc.). Conhece-se, também, doenças como a ferrugem, o cancro, as manchas foliares, a gomose, etc.. Através desses conhecimentos é obtido um controle mais eficaz dessas pragas e doenças, controle este que abrange a escolha da espécie mais adequada, constantes inspeções das florestas, uso de produtos químicos, controle biológico, etc.. Hoje, o controle de plantas daninhas pode ser feito manualmente, mecanicamente e/ou através do uso de herbicidas, sendo que o pinus necessita de maior freqüência de realização desta operação que o eucalipto.

O eucalipto, no sistema de produção inicial, era manejado, principalmente, através do sistema de regeneração denominado "Alto Fuste", no qual não havia cortes periódicos, pois pretendia-se produzir madeira de grandes dimensões. Assim, as florestas eram formadas, inicialmente, através de mudas e depois eram deixadas intactas até que se tornassem aptas a serem cortadas - o que levava, em geral, cerca de 40 anos (florestas de ciclo longo). Os cortes subseqüentes davam-se nas árvores provenientes das sementes 
que caiam naturalmente das árvores mais velhas. Este processo continuava ocorrendo até que a densidade da área, em árvores, diminuísse a um ponto em que um novo plantio era necessário.

Também era utilizado para o eucalipto, só que em menor escala, um sistema de regeneração denominado "Talhadia", o qual era caracterizado pelo corte periódico das árvores - dando-se o nome de rotação ao lapso de tempo compreendido entre dois cortes sucessivos. $\mathrm{Na}$ talhadia, cortavam-se as árvores a uma altura de 5 a $15 \mathrm{~cm}$ a partir do solo, aproveitando-se de uma caracteristica do eucalipto que é a sua capacidade de regeneração através da brotação da cepa (que é o resto da árvore que fica no solo após o corte).

O pinus, devido à ausência de brotação após o corte, era manejado pelo sistema "Alto Fuste".

De uma forma geral, podemos dizer que os sistemas de produção iniciais, tanto para o eucalipto quanto para o pinus, não davam condições para a realização de um sistema de manejo mais intensivo. Com o passar dos anos, ocorreram inovações tecnológicas que permitiram que hoje as florestas sejam conduzidas de forma intensiva. Por esta razão, no Brasil, atualmente, o sistema de regeneração para eucalipto tem sido o de "Talhadia", onde maneja-se a brotação das cepas após cortes realizados, em geral, aos 5 - 7 anos, 10 - 15 anos, ficando o corte final aos 15 - 21 anos (florestas de ciclo curto). Para a obtenção de bons resultados neste manejo das cepas, há uma série de fatores que devem ser observados, como: a escolha das espécies, a altura de corte, a época de corte (a porcentagem de brotação e taxa de crescimento dos brotos são maiores nos cortes realizados no verão), o diâmetro das cepas no corte (maior o diâmetro, maior o número de brotos), entre outros.

Mesmo para o pinus, que não se regenera através de brotações das cepas, o sistema atual tornou-se bem mais intensivo, havendo várias opções de manejo de acordo com a finalidade de produção. Assim, na produção de madeira destinada à elaboração de pastas, há um ciclo curto, sem desbaste (corte seletivo de árvores menos promissoras que permite que as demais cresçam sob melhores condições), com corte raso na data de estagnação, aos 14 anos mais ou menos; já na produção de madeira para o 
processamento mecânico, há um ciclo longo, com desbastes, sendo o corte raso aos 25 anos mais ou menos, etc..

Quanto à colheita (corte, extração e transporte) - que no sistema de produção inicial era realizada com machado e sistemas com força humana e com força animal para a extração e o transporte, principalmente - evoluímos para um processo estruturado e complexo, que varia conforme as condições (topografia, nível da capacidade de mecanização, rendimento volumétrico da floresta, etc.) e as finalidades. Hoje, o corte é, na sua maioria, feito com motosserra, sendo que já se encontra no mercado uma colheitadora florestal para o corte, desgalhamento e traçamento - o "Harvester". A extração pode ser realizada por sistemas com força humana, força animal e também com força mecânica - há várias opções destes, como guinchos, tratores agrícolas com guinchos de arraste ou berços, caminhões com grua, trator florestal ("Forwarder"), tratores da arraste de madeira ("Skidders"), etc.. O transporte, atualmente, é feito, principalmente, por caminhões, escolhidos em função da distância, do tipo de estrada, quantidade de madeira a ser transportada, etc..

Desta comparação dos sistemas de produção iniciais e atuais do eucalipto e do pinus, percebemos que houve uma grande evolução no nível da tecnologia utilizada. Esta mudança na tecnologia empregada pode ser atribuída a um processo de desenvolvimento da pesquisa, que acabou gerando um grande número de inovações tecnológicas importantes. Assim sendo, é necessário um item analisando os esforços de pesquisa e a adoção de tecnologia mais moderna na silvicultura brasileira (item 2.3).

\section{3 - As Pesquisas e as Inovações Tecnológicas na Silvicultura Brasileira}

Como já mencionamos na introdução deste Capítulo 2, os trabalhos de pesquisa podem gerar resultados que trazem novas propostas de técnicas, de produtos, de padrões de comportamento e operacionalização, novos conceitos a serem implementados. Se estas novas propostas forem adotadas, incorporando-se aos sistemas de produção, serão consideradas inovações tecnológicas. 
Neste item, pretendemos analisar a evolução das pesquisas e das inovações tecnológicas ocorridas na silvicultura brasileira de forma a elucidar as distinções e relações que existem entre a ciência e a aplicação de tecnologia. Nesta análise, vamos utilizar, de forma relacionada: quadros onde estão dispostos, cronologicamente, o número de trabalhos científicos sobre pinus e eucalipto de acordo com os segmentos de cada área de pesquisa; os critérios de classificação das inovações tecnológicas (item 2.1), a comparação dos sistemas de produção (item 2.2) e um quadro com a evolução quantitativa dos trabalhos de pesquisa sobre espécies nativas e exóticas na silvicultura brasileira.

\subsection{1 - Relação entre Pesquisa e Inovação Tecnológica}

SILVA (1982) menciona que o progresso tecnológico vem sendo crescentemente enfatizado como fonte de desenvolvimento econômico desde o início dos anos cinqüenta, quando estudos empíricos, analisando o crescimento do produto não explicado pelo aumento do uso de fatores convencionais, permitiram avaliar a importância da mudança tecnológica (ver estudo pioneiro de SOLOW,1951) ${ }^{14}$. Ainda segundo SILVA (1982), a partir da década de sessenta, ficou claro o papel preponderante da pesquisa na geração de novas técnicas produtivas, tanto na forma de conhecimentos diretamente aplicados à produção, quanto na forma de conhecimentos incorporados a fatores materiais utilizados no processo produtivo.

Segundo ARAÚJO $(1989$, p.23), a ciência forneceu à agricultura assistência muito limitada em termos de novas tecnologias, sendo que isto começou a mudar no momento da explosão de conhecimentos gerados na biologia, química orgânica, bioquímica, microbiologia, genética e informática, que permitiram, no século $\mathrm{XX}$, e a partir dos anos setenta no Brasil, transformações radicais no processo produtivo agrícola.

14 SOLOW, R.M. (1951) "Technical change and the aggregate production function". Review of Economics and Statistics. 39:312-320, 1951. 
Ainda conforme ARAÚJO (1989, p.32), o potencial da ciência no sentido de promover o desenvolvimento econômico passou a ser cada vez maior. Entretanto, advertiu este mesmo autor, "a ciência em si tende a contribuir pouco para este fenômeno complexo, na ausência de alguns insumos adicionais, na falta de capacidade técnica de alto nível, de fortes sistemas de incentivos, estruturas organizacionais flexíveis, podendose argumentar que mesmo uma comunidade científica altamente criativa na ausência desses elementos teria resultados econômicos medíocres".

SILVA (1992), após a discussão de uma série de trabalhos, concluiu que gastos com pesquisas que geram inovações tecnológicas apresentam ganhos sociais agregados líquidos, reafirmando, assim, a idéia de que o progresso tecnológico é essencial para o desenvolvimento econômico.

Mesmo as mudanças tecnológicas não tendo, obrigatoriamente, relação direta com a ciência, podemos dizer que para o caso da agricultura e, especificamente, para o caso da silvicultura, houve e continua havendo uma intensa influência - que age conjuntamente, mas que não é exclusiva - entre demanda por inovações, trabalhos de pesquisa e adoção de inovações tecnológicas. Além disso, o aumento da importância atribuída à obtenção de inovações tecnológicas que proporcionassem aprimoramentos nos sistemas de produção fez com que se procurasse um amplo domínio dos meios de se chegar até elas, estando a pesquisa compreendida entre estes meios.

Vários elementos concorreram para a evolução das pesquisas na silvicultura brasileira. O impulso básico para esta evolução pode ser atribuído à própria necessidade de se superar as restrições impostas pelo ambiente a um desenvolvimento que era necessário, ou seja, houve necessidade da pesquisa à medida que inovações tecnológicas foram demandadas para se suplantar a escassez dos fatores de produção (evidenciada, por exemplo, pelo aumento de seus preços relativos). Além deste impulso básico, vários outros fatores também tiveram sua influência sobre as pesquisas na silvicultura brasileira. Entre estes fatores, podemos citar: o legado internacional (ou seja, experiências e descobertas ocorridas em outros países, geralmente mais adiantados, chegando até o Brasil por algum processo de difusão de tecnologia e servindo de base e estímulo à pesquisa nacional); as experiências com outras culturas (ou seja, o desenvolvimento da 
pesquisa em outras culturas abrindo perspectivas para a pesquisa na silvicultura) e o apoio institucional (através de investimentos em instituições e programas públicos de pesquisa e de incentivos ao desenvolvimento da pesquisa em empresas privadas).

Para gerar as pesquisas na silvicultura houve uma interação entre produtores, empresas fornecedoras de insumos e instituições públicas de pesquisa, principalmente, num ciclo onde a expansão da atividade (associada à escassez dos fatores de produção) exigia inovações tecnológicas que proporcionassem alternativas eficientes (que aumentassem a lucratividade). Estas inovações, por sua vez, somente seriam obtidas caso houvesse um esforço nacional de pesquisa. Por outro lado, ao ocorrer o desenvolvimento da pesquisa, gerando inovações tecnológicas importantes, a atividade silvicultora sofreria uma nova expansão, que demandaria mais inovações, e o processo continuaria.

\subsection{2 - As Pesquisas na Silvicultura Brasileira}

A Tabela 2 apresenta a evolução da quantidade de trabalhos científicos publicados no Brasil sobre espécies arbóreas exóticas (eucalipto e pinus), espécies nativas e sobre espécies de araucária. Percebemos a predominância de trabalhos científicos publicados $(\mathrm{e}$, assim, da própria pesquisa desenvolvida) sobre as espécies de pinus e eucalipto. Esta supremacia dos estudos sobre estas espécies exóticas tem o seu auge na década de setenta (período de vigência dos incentivos fiscais), quando o número de trabalhos científicos publicados sobre pinus e eucalipto sempre superou a soma dos trabalhos científicos publicados sobre espécies nativas e sobre espécies de araucária (exceção para o ano de 1979). A partir da década de oitenta e, principalmente, da década de noventa, já podemos perceber uma maior preocupação com estudos sobre as espécies nativas (acompanhando, possivelmente, a tendência de uma maior procura pela exploração sustentável, por uma preocupação com questões ambientais, etc.). 
TABELA 2 - EVOLUÇÃO DA QUANTIDADE DE TRABALHOS CIENTÍFICOS PUBLICADOS SOBRE ESPÉCIES EXÓTICAS (PINUS E EUCALIPTO), ESPÉCIES NATIVAS E SOBRE ESPÉCIES DE ARAUCÁRIA.

\begin{tabular}{|c|c|c|c|c|c|c|}
\hline \multirow[t]{2}{*}{ Ano } & Pinus & Eucalipto & Espécies & Nativas & Espécies de & Araucária \\
\hline & $\begin{array}{c}\text { número de } \\
\text { trabalhos } \\
\text { publicados }\end{array}$ & $\begin{array}{l}\text { Participação } \\
\text { Relativa (\%) }\end{array}$ & $\begin{array}{l}\text { número de } \\
\text { trabalhos } \\
\text { publicados }\end{array}$ & $\begin{array}{l}\text { Participação } \\
\text { Relativa (\%) }\end{array}$ & $\begin{array}{l}\text { número de } \\
\text { trabalhos } \\
\text { publicados }\end{array}$ & $\begin{array}{l}\text { Participação } \\
\text { Relativa (\%) }\end{array}$ \\
\hline 1953 & 7 & 43,75 & 6 & 37,50 & 3 & 18,75 \\
\hline 1969 & 1 & 33,33 & 1 & 33,33 & 1 & 33,33 \\
\hline 1970 & 12 & 70,59 & 2 & 11,76 & 3 & 17,65 \\
\hline 1971 & 10 & 58,82 & 2 & 11,76 & 5 & 29,42 \\
\hline 1972 & 13 & 61,90 & 4 & 19,05 & 4 & 19,05 \\
\hline 1973 & 34 & 68,00 & 14 & 28,00 & 2 & 4,00 \\
\hline 1974 & 8 & 66,70 & 3 & 25,00 & 1 & 8,33 \\
\hline 1975 & 6 & 50,00 & 5 & 41,67 & 1 & 8,33 \\
\hline 1976 & 9 & 69,23 & 1 & 7,69 & 3 & 23,08 \\
\hline 1977 & 26 & 70,27 & 7 & 18,92 & 4 & 10,81 \\
\hline 1978 & 45 & 73,77 & 13 & 21,31 & 3 & 4,92 \\
\hline 1979 & 14 & 48,28 & 11 & 37,93 & 4 & 13,79 \\
\hline 1980 & 14 & 63,64 & 6 & 27,27 & 2 & 9,09 \\
\hline 1981 & 23 & 63,89 & 9 & 25,00 & 4 & 11,11 \\
\hline 1982 & 19 & 36,54 & 25 & 48,08 & 8 & 15,38 \\
\hline 1983 & 101 & 67,79 & 42 & 28,19 & 6 & 4,03 \\
\hline 1984 & 16 & 69,56 & 7 & 30,44 & - & 0,00 \\
\hline 1985 & 9 & 42,86 & 11 & 52,38 & 1 & 4,76 \\
\hline 1986 & 67 & 61,47 & 40 & 36,70 & 2 & 1,83 \\
\hline 1987 & 8 & 36,36 & 13 & 59,09 & 1 & 4,55 \\
\hline 1988 & 14 & 66,67 & 5 & 23,81 & 2 & 9,52 \\
\hline 1989 & 13 & 54,17 & 7 & 29,17 & 4 & 16,66 \\
\hline 1990 & 49 & 55,06 & 38 & 42,70 & 2 & 2,24 \\
\hline 1991 & 9 & 47,37 & 10 & 52,63 & - & 0,00 \\
\hline 1992 & 18 & 66,67 & 9 & 33,33 & - & 0,00 \\
\hline 1993 & 58 & 49,15 & 59 & 50,00 & 1 & 0,85 \\
\hline 1994 & 13 & 56,52 & 10 & 43,48 & - & 0,00 \\
\hline
\end{tabular}

FONTES: REVISTA FLORESTA (1969 a 1992)

REVISTA IPEF (1970 a 1994)

REVISTA ÁRVORE (1977 a 1994)

CONGRESSOS FLORESTAIS BRASILEIROS (1953, 1973, 1978, $1983,1986,1990$ e 1993) 
No presente texto, nos ateremos a analisar os tipos de pesquisas feitos com eucalipto e pinus, que são as principais espécies arbóreas reflorestadas no Brasil.

Para analisar a evolução das pesquisas brasileiras sobre eucalipto e pinus, elaboramos o Quadro 3, no qual estão dispostos, cronologicamente, a quantidade de trabalhos científicos publicados no Brasil sobre essas espécies de acordo com os segmentos de cada área de pesquisa. Baseamo-nos, para a construção desse quadro, nas revistas FLORESTA (no período de 1969 a 1992), IPEF (no período de 1970 a 1994) e ÁRVORE (no período de 1977 a 1994) e nos Anais do I, II, III, IV, V, VI e VII CONGRESSOS FLORESTAIS BRASILEIROS, realizados nos anos de 1953, 1973, 1978, 1983, 1986, 1990 e 1993, respectivamente. Estes são os principais veículos de divulgação da produção científica sobre a silvicultura no Brasil. No Apêndice A, temos as referências bibliográficas dos trabalhos classificados no Quadro 3.

Importante mencionarmos que nos respectivos anos de suas ocorrências, os Congressos Florestais Brasileiros ampliam a quantidade total dos trabalhos científicos publicados no Brasil. Entretanto, a leitura do Quadro 3 (a exemplo do que ocorre com a Tabela 2) deve ser feita no sentido de marcar o início, a intensificação e a diminuição ocorridas em cada área de pesquisa, ou seja, procuramos demonstrar tendências. 


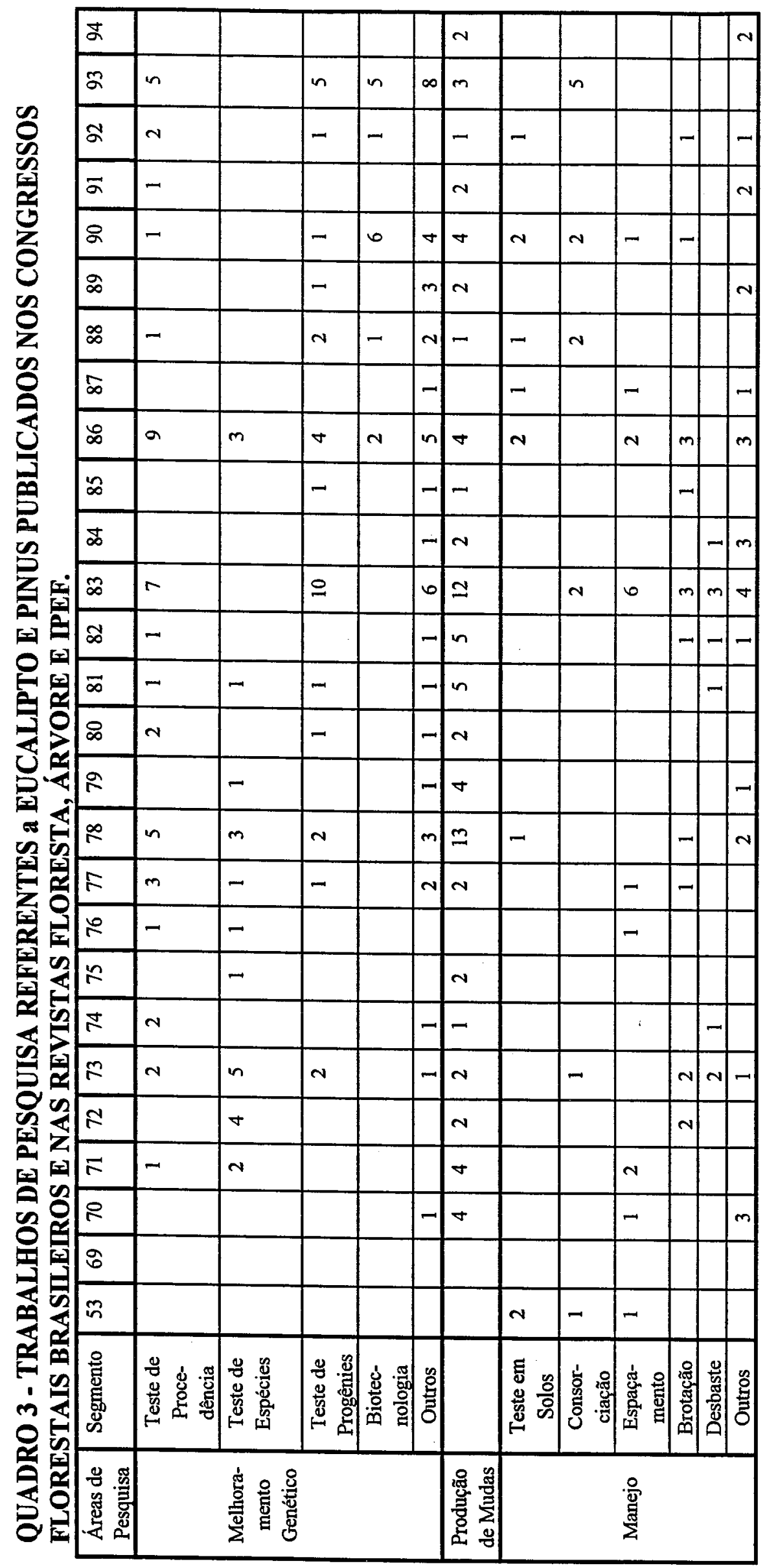




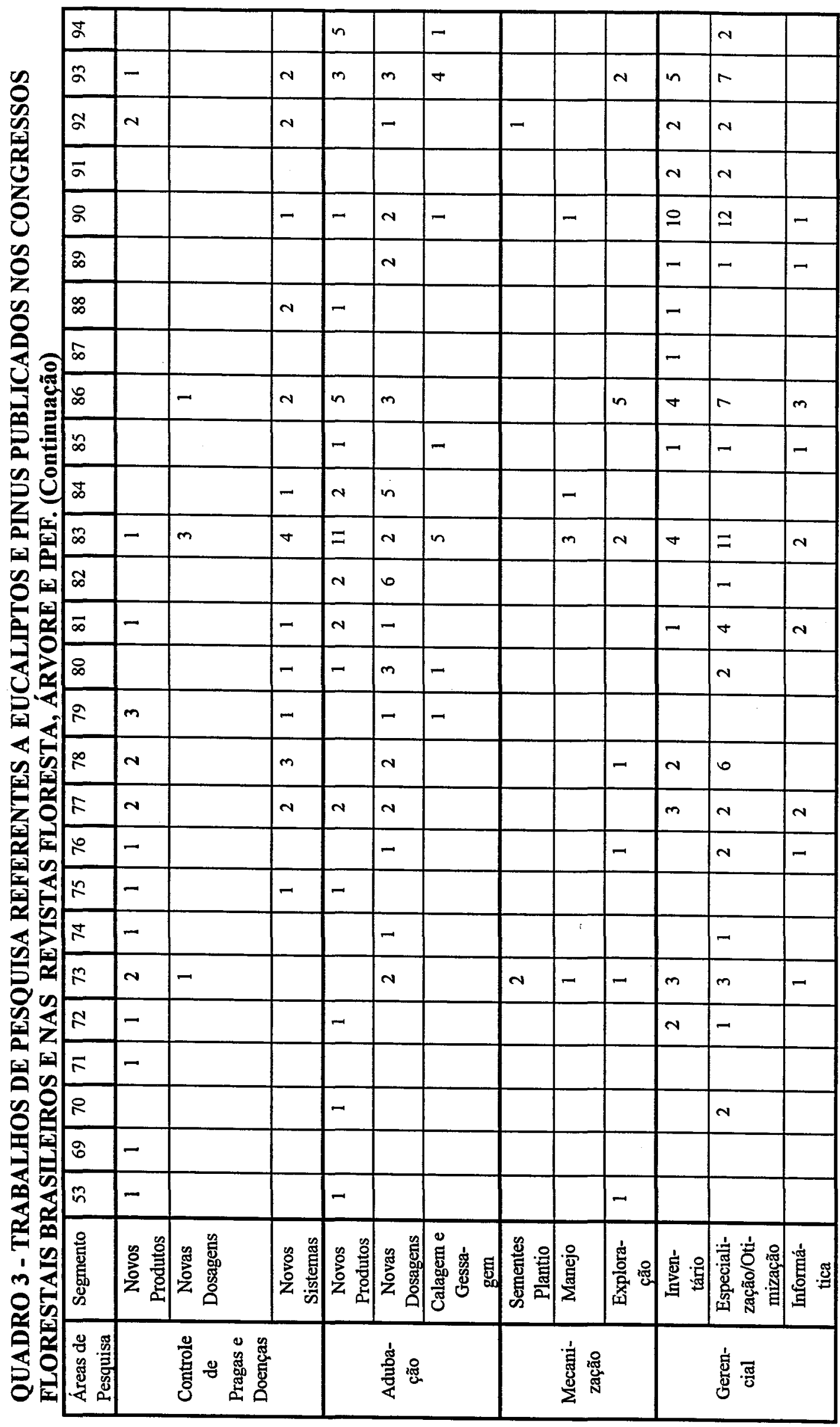


Em 1953, o I Congresso Florestal Brasileiro sintetizou muito bem quais as áreas de pesquisa sobre eucalipto e pinus que foram consideradas necessárias e possíveis de serem desenvolvidas diante do cenário então vigente. Naquela época, os estudos publicados voltaram-se, na sua maioria, para a área de manejo da floresta. Vários trabalhos de pesquisa foram realizados em segmentos como testes de espécies em solos específicos, consorciação e espaçamento, sendo que estes trabalhos foram desenvolvidos em ambientes locais, isto é, para condições edafo-climáticas específicas, sendo que seus resultados apresentaram contribuição discreta para possíveis aumentos de produtividade. Além disso, diante da inexistência, até então, de técnicas silviculturais padronizadas, esses trabalhos publicados foram recomendados de forma conjunta, inseridos sob a idéia de um pacote tecnológico.

NAVARRO DE ANDRADE (1953, p.95) e até mesmo as próprias conclusões gerais obtidas no I Congresso Florestal Brasileiro recomendavam atenção na escolha do solo, época de plantio, espaçamento, consorciação, limpeza da área, etc..

É importante mencionar que já havia alguns poucos trabalhos relacionados ao controle de pragas e doenças e à adubação, práticas estas que, em geral, ainda não eram comumente realizadas na silvicultura. Nas outras áreas de pesquisa, praticamente nada foi realizado.

A silvicultura do Brasil sofreu um grande impulso na década de setenta com os incentivos fiscais destinados a promover esta atividade. Houve um grande aumento da área reflorestada e da pesquisa, cujos resultados - apesar de não serem rápidos devido às características da cultura de espécies florestais - acabaram gerando várias propostas de novas técnicas.

Nesse contexto de expansão da silvicultura, percebemos a ocorrência de um aumento do número de trabalhos de pesquisa (em relação aos anos anteriores), bem como das áreas e segmentos pesquisados.

Após a fase inicial dos estudos exclusivos sobre a área de manejo, a área de melhoramento genético foi a primeira a apresentar um certo desenvolvimento. Assim, já a partir do início da década de setenta, de todos os trabalhos que acabaram gerando resultados importantes, os relacionados à área de melhoramento genético foram os que 
apresentaram maior impacto sobre a silvicultura brasileira, ou seja, apresentaram um maior potencial para aumentar a produtividade.

Mesmo já havendo alguns trabalhos pioneiros sobre testes de progênies, o que houve de marcante na área de melhoramento genético, por toda a década de setenta, em termos de resultado de pesquisa - sendo rapidamente adotado, difundido e provocando grandes aumentos de produtividade - foi a realização de testes de procedência e testes de espécies. Estes testes consistiam na comparação, através de critérios pré-estabelecidos, de várias procedências e/ou espécies para a determinação das mais aptas para se desenvolverem sob nossas condições edafo-climáticas, sendo que estes procedimentos tinham um único objetivo: formar uma população florestal com base genética superior, até então inexistente, para a silvicultura brasileira.

Os resultados desses trabalhos iniciais na área de melhoramento genético começaram a aparecer já a partir da década de oitenta. Por esta razão, na primeira metade da década de oitenta, verificamos uma tendência de substituição dos testes de espécies por testes mais específicos, como os testes de procedência e, principalmente, os testes de progênies (com a função de analisar a variabilidade genética já existente no Brasil).

Por toda a década de oitenta houve, também, uma preocupação com o desenvolvimento de técnicas que facilitassem e acelerassem o processo de melhoramento genético, sendo que, entre elas, estavam os métodos da enxertia, do enraizamento de estacas, da polinização controlada para a produção de híbridos, etc..

$\mathrm{Na}$ segunda metade da década de oitenta, percebemos 0 início do desenvolvimento de pesquisas na área de biotecnologia, a qual apresenta um grande potencial para tornar mais eficiente e eficaz o processo de melhoramento genético.

As pesquisas na área de produção de mudas apresentaram um desenvolvimento acentuado e contínuo desde o início da década de setenta até os dias de hoje, passando a ser consideradas essenciais para a expansão da silvicultura brasileira. Dentre os trabalhos de pesquisa desenvolvidos, podemos mencionar os relacionados aos tipos de recipientes, aos tipos de substratos, aos tipos de cobertura das embalagens, aos efeitos de alguns fatores sobre a germinação (tais como temperatura, umidade, etc..), etc.. As pesquisas na 
área de adubação, por exemplo, foram totalmente direcionadas, inicialmente, para a área de produção de mudas.

Nos últimos anos, pudemos perceber uma tendência das pesquisas referentes à produção de mudas se orientarem para o desenvolvimento e aprimoramento de sistemas mecanizados. Além disso, houve uma preocupação com a otimização da utilização desses sistemas, isto é, pesquisas foram realizadas com o intuito de dar usos múltiplos e contínuos durante o ano para os sistemas de produção de mudas.

Como já mencionamos anteriormente, as pesquisas na área de manejo foram as primeiras a serem desenvolvidas na silvicultura brasileira (isto já no início deste século), sendo que a importância atribuída a esta área mantém-se até os dias de hoje. Assim, podemos dizer que durante todo este século, houve um grande número de trabalhos de pesquisa sobre espaçamento, poda, desbaste, brotação, consorciação, testes em solos, etc.. A escolha das espécies adequadas para o plantio, por exemplo, foi bastante favorecida por trabalhos realizados sobre zoneamento ecológico do País para o reflorestamento (como o de GOLFARI ,1978).

Esta constante importância atribuída à área de manejo pode ser explicada pela necessidade que esta área apresentava (e ainda apresenta) de ajustar-se frente ao desenvolvimento acelerado das pesquisas nas outras áreas.

Outra área de pesquisa que ganhou destaque a partir da década de setenta foi a de controle de pragas e doenças. De forma geral, podemos dizer que a sequiência ocorrida nos estudos sobre esta área foi a seguinte: inicialmente, foram pesquisadas e descritas as pragas e doenças que causavam danos econômicos às espécies utilizadas no reflorestamento/florestamento; logo em seguida, trabalhos foram desenvolvidos com o objetivo de testar os efeitos de vários produtos sobre estas pragas e doenças; e, finalmente, pesquisas foram feitas visando determinar as melhores dosagens a serem empregadas nos vários produtos em uso.

No início do desenvolvimento das pesquisas nessa área, os resultados obtidos ainda eram muito restritos, provocando pequenos aumentos na produtividade quando implementados na prática, mas, com o passar do tempo, a eficácia do controle aumentou. 
A partir do final da década de setenta, principalmente, percebemos uma tendência na pesquisa para o estudo de novas alternativas para o controle de pragas e doenças, onde uma preocupação com as condições ambientais era evidente. Entre estes trabalhos, podemos citar os que estudavam o controle biológico, o manejo integrado de pragas, o desenvolvimento de indivíduos resistentes a certos tipos de pragas e doenças, etc..

As pesquisas na área de adubação também ganharam impulso com o início, a partir de 1966, dos incentivos fiscais ao reflorestamento/florestamento. FERREIRA (1993, p.157), no entanto, disse que apesar do desenvolvimento de várias pesquisas sobre adubação no período de 1973 a 1981, estas concentravam-se em viveiros e não em adubação de campo. A maioria dos plantios continuaram usando, basicamente, a mesma formulação NPK, independentemente do tipo de solo e das exigências nutricionais das espécies.

A criação do Grupo Permanente de Trabalho em Nutrição e Fertilização Florestal (G.P.T.N.F.F.), sob a inspiração do Programa Nacional de Pesquisa Florestal, em 1983, representou um marco na pesquisa em nutrição florestal no Brasil.

Provavelmente, devido ao aumento da conscientização sobre a necessidade e importância da realização da operação de adubação para a obtenção de melhorias nos níveis de produtividade, houve um grande desenvolvimento da pesquisa nesta área (em geral, pesquisas testando novos produtos e, posteriormente, pesquisas testando dosagens desses produtos).

As pesquisas sobre calagem e gessagem foram quase sempre restritas, tomando um maior impulso somente a partir da década de oitenta, sendo que esta pouca atenção às pesquisas neste segmento pode ser explicada, possivelmente, pela imagem de rusticidade que as espécies florestais sempre transmitiram aos silvicultores, o que, em última análise, acabava, também, influenciando o desenvolvimento de novos estudos.

$\mathrm{Na}$ década de noventa, percebemos o início de uma tendência nas pesquisas na área de adubação no sentido de uma procura por produtos alternativos, de mais baixo custo. Assim, por exemplo, a partir dessa época, encontramos trabalhos que analisavam a eficácia de vários produtos tais como alguns tipos de fosfatos naturais, compostos 
orgânicos (como o lodo de esgoto e os resíduos das próprias florestas), resíduos industriais, etc..

Em toda a história da pesquisa na silvicultura brasileira, a área de mecanização foi a que apresentou o menor número de trabalhos desenvolvidos. A pesquisa nesta área, apesar de pequena, teve seu primeiro impulso a partir da década de setenta (a exemplo da maioria das demais áreas de pesquisa). Entretanto, por um longo período, a característica mais marcante desta área foi a importação de tecnologia. Uma década após o início dos incentivos fiscais concedidos ao reflorestamento/florestamento, cerca de 60 a 70 por cento das máquinas em uso na silvicultura brasileira eram importadas (Silvicultura, 1977, p.12).

Os trabalhos na área de mecanização consistiam, basicamente, na comparação e adaptação de vários produtos importados, não havendo, assim, o desenvolvimento de pesquisas específicas para as condições brasileiras.

A partir da década de noventa, o cenário passou a ser um pouco mais favorável à pesquisa brasileira na área de mecanização. Segundo CARDONA (1992, p. 44 - 46), a diminuição da oferta de mão-de-obra, a natureza árdua do trabalho florestal e a busca de uma maior produtividade foram fatores que levaram à procura pela mecanização das operações florestais, uma alternativa que podia levar a uma redução dos custos operacionais (tornando os produtos brasileiros mais competitivos no exterior) e que podia incentivar o desenvolvimento da pesquisa brasileira na área de mecanização.

Mesmo sendo encontrados alguns trabalhos já a partir da década de setenta na área gerencial (principalmente no segmento inventário florestal), esta pode ser considerada a última área da pesquisa na silvicultura brasileira a ser desenvolvida, sendo que um maior impulso somente ocorreu a partir da década de oitenta.

AHRENS (1987, p.17), por exemplo, em 1987, disse que a produção florestal seria tanto melhor efetivada quanto mais eficientes fossem a utilização e o controle dos processos de produção e dos seus fatores componentes. A pesquisa em produção florestal deveria ser feita objetivando uma avaliação quantitativa do fenômeno de crescimento individual das árvores e dos povoamentos florestais, considerando-se a sua associação com características do sítio e com os tratamentos silviculturais que tivessem 
sido ou que pudessem ser aplicados. Uma extensão natural desses conceitos era a possibilidade de tratar as informações quantitativas disponíveis por meio de técnicas de modelagem, de simulação e de otimização. Em suma, este autor defendia a essencialidade e necessidade de pesquisas na área gerencial a partir daquela época.

As pesquisas na área gerencial podem ser divididas em três segmentos principais: inventário florestal (o primeiro segmento de pesquisa nesta área a apresentar um maior desenvolvimento, onde aparecem trabalhos sobre equações e métodos para a estimativa do volume de madeira das florestas, principalmente); otimização/especialização (compreendendo trabalhos sobre vários tipos de análises econômicas, sobre especialização da mão-de-obra, sobre divisão de operações, sobre sensoriamento remoto, sobre segurança no trabalho, ergonomia, sistemas de coleta de dados, etc.) e informática (o último segmento a ser desenvolvido, apresentando trabalhos que envolvem "softwares", técnicas de programação linear, simulação, etc..).

Uma avaliação global das pesquisas em melhoramento genético, produção de mudas, manejo, controle de pragas e doenças, adubação, mecanização e gerenciamento nos mostra que os estudos se intensificaram a partir da década de setenta. Isto pode ser, em parte, explicado pela ação conjunta de dois fatores: um maior desenvolvimento da pesquisa agropecuária como um todo a partir desta época e o início dos incentivos fiscais ao reflorestamento/florestamento, ocorrido em 1965. Com esses incentivos concedeu-se recursos à pesquisa $(1 \%$ dos recursos dos incentivos fiscais devia ser alocado à pesquisa florestal) e dinamizou-se o reflorestamento/florestamento, criando-se demanda por inovações tecnológicas, o que pressionou a realização de pesquisas florestais.

O fim dos incentivos fiscais acelerou o processo de desenvolvimento de estudos e pesquisas em áreas e segmentos que pudessem oferecer inovações tecnológicas que proporcionassem um sistema eficiente, de baixo custo, de rápidos resultados e decisões, onde a qualidade e a proteção ambiental estivessem presentes, tudo isto objetivando uma melhor competitividade no mercado. Isto pode ser exemplificado pelos tipos de trabalhos desenvolvidos a partir de então: trabalhos em biotecnologia, controle biológico de pragas, adubação alternativa (resíduos industriais e urbanos) e informática. 


\subsection{3 - A Evolução das Inovações Tecnológicas na Silvicultura Brasileira}

O início da introdução em larga escala do eucalipto no Brasil, realizada pela Companhia Paulista de Estradas de Ferro (sob o comando de Edmundo Navarro de Andrade), em 1909, foi o fato gerador de uma grande revolução que neste período só se iniciava, mas que já começava a modificar a incipiente silvicultura brasileira.

Em toda a primeira metade do atual século, difundiu-se e fortificou-se a idéia da utilização de uma cultura florestal de ciclo curto para a obtenção de madeira destinada aos mais variados fins. $\mathrm{O}$ sistema de produção desenvolvido, usado e recomendado pela Companhia Paulista de Estradas de Ferro, entretanto, quase que não se alterou neste referido período (primeira metade do atual século). $O$ fato do cultivo do eucalipto ser ainda uma atividade pouco conhecida da silvicultura, aliado às características tecnológicas da agricultura de então, fizeram com que os estudos silviculturais se voltassem para aspectos básicos e gerais, porém essenciais para um impulso inicial. Assim, podemos perceber que algumas inovações tecnológicas específicas para a área de manejo foram ocorrendo à medida que mais árvores de eucalipto íam sendo plantadas e, conseqüentemente, novos obstáculos e desafios íam aparecendo. Portanto, ocorreram inovações tecnológicas na silvicultura brasileira à medida que novos espaçamentos e novas formas de cortes passaram a ser usadas. Inovou-se, também, quando a prática da consorciação do eucalipto com outras culturas foi implementada, quando testes de espécies em solos específicos passaram a ser feitos, etc..

Foram inovações tecnológicas que podem ser classificadas como agronômicas, de processo, pequenas (pois alteraram pouco a produtividade) e nacionais. Diante da inexistência de técnicas silviculturais pradronizadas, essas inovações vieram em conjunto (espaçamento, consorciação, tratos culturais, forma de corte, etc..), sob a forma de um pacote tecnológico. Nas outras áreas (ou seja, melhoramento genético, produção de mudas, controle de pragas e doenças, adubação, mecanização e gerencial) não houve inovações, ou seja, dos poucos trabalhos desenvolvidos, praticamente nada foi implementado. 
A partir do final dos anos cinqüenta, grandes avanços foram ocorrendo na agricultura como um todo e, conseqüentemente, na silvicultura brasileira.

Com os incentivos fiscais ao florestamento e reflorestamento a silvicultura foi impulsionada. Este impulso trouxe novas necessidades, novos problemas, etc.. Houve pesquisas em diversas áreas e segmentos, cujos resultados foram relevantes, sendo por isso aplicados e transformando-se em inovações tecnológicas importantes.

Continuaram ocorrendo inovações tecnológicas na área de manejo - tais como novos espaçamentos, novos métodos de corte, de poda e de eliminação de brotos (inovações tecnológicas agronômicas, de processo, pequenas e nacionais) - só que desta vez associadas a uma série de outras inovações, como as ocorridas nas áreas de controle de pragas e doenças e adubação - novos produtos (inovações tecnológicas químicas, de produto) e novas dosagens (inovações tecnológicas quimicas, de processo) - e na área gerencial, principalmente no segmento inventário florestal (inovação tecnológica gerencial de processo).

Contudo, como já mencionado no item 2.3.2, de todas as inovações tecnológicas incorporadas aos sistemas de produção deste período, as ocorridas na área de melhoramento genético foram as que mais se destacaram. Este destaque deveu-se, principalmente, à rápida difusão dessas inovações e aos aumentos de produtividade provocados por elas.

De acordo com a EMBRAPA - RELATÓRIO DE ATIVIDADES (1983 - 1984), somente a indicação de espécies e a utilização de procedências de sementes potenciais às principais áreas destinadas ao reflorestamento, aliadas à adoção de algumas práticas silviculturais adequadas (ambas geradas pela pesquisa florestal desenvolvida no Brasil, até o final da década de 70 ), tornaram possíveis aumentos de $50 \%$, em média, na produtividade do eucalipto e do pinus.

MAGALHÃES (1986, p.5), analisando a década de setenta, disse que estava ocorrendo uma evolução no sentido de substituir os plantios com sementes de Rio Claro (com origem do Sul da Austrália), que resultavam em plantios irregulares, heterogêneos e de baixa produtividade, por plantios com emprego de sementes testadas, de origens estudadas (oriundas da Austrália, Indonésia, Filipinas, África do Sul, etc..). Estas 
inovações ocorridas na área de melhoramento genético podem ser classificadas como inovações tecnológicas biológicas, tanto de produto (pois novas espécies foram introduzidas), quanto de processo (novos métodos para a escolha de espécies, como, por exemplo, testes de comparação entre latitudes do Brasil e da Oceania, testes de procedências, etc.), grandes (pois provocaram grandes aumentos de produtividade) e nacionais.

Com toda essa evolução em termos de inovações tecnológicas, os sistemas de produção foram modificando-se (novas técnicas, produtos e conceitos foram sendo introduzidos) e a produtividade elevou-se. Houve, portanto, o implemento de um novo pacote tecnológico, mais abrangente, mais completo.

Depois de 1974, a maioria dos plantios começou a receber adubação no momento de seu implemento. FERREIRA (1993, p.157) explica que os plantios efetuados no início do período de expansão não eram adubados - causa ou efeito da falta de inovações nesta área - mas que a queda da produtividade devida à ocupação, ao longo do tempo, de solos de baixa fertilidade despertou o interesse na utilização de fertilizantes nos novos plantios.

Entretanto, mesmo nesse cenário de expansão, VICTOR (1977, p.18-41) assinalou algumas restrições, dizendo que o Brasil, no que diz respeito a uma política científica global, de 1960 a 1976, não tinha incorporado sequer um décimo da tecnologia que poderia e deveria ter produzido em laboratórios de pesquisa, públicos e privados. Quanto ao caso específico da silvicultura, havia a necessidade de uma avaliação mais específica. Um fato interessante é que este autor ratifica a afirmação de que somente a aplicação de tecnologia própria e uso de material genético superior tinham possibilitado obter grandes aumentos de produtividade no período.

No que se refere ao uso de material genético superior, segundo o IV ENCONTRO NACIONAL DE REFLORESTADORES (1978), o volume disponível de sementes de pinus era, em 1978, ainda insuficiente para atender à crescente demanda nacional e, também, duvidoso em relação à qualidade das sementes importadas (que representavam $80 \%$ das necessidades nacionais). 
$\mathrm{Na}$ área de mecanização, a tendência era, no final da década de setenta, de importação de tecnologia, sendo poucas as inovações obtidas para as condições específicas do Brasil.

A década de oitenta começou com uma sensível diminuição da importação de material genético de eucalipto, visto que, no Brasil, já havia uma população florestal com base genética superior, fruto de um grande trabalho de pesquisa nesta área (como visto no item 2.3.2). Ainda na área de melhoramento genético, houve a aplicação de técnicas de polinização controlada visando a produção de híbridos (por exemplo, Eucalyptus grandis x Eucalyptus saligna); ampliou-se o uso de métodos de clonagem ${ }^{15} \mathrm{e}$ os testes entre espécies passaram a ser substituídos por testes mais específicos, os chamados testes de progênies (que eram testes que objetivavam selecionar os melhores indivíduos produzidos a partir de um cruzamento específico). Essas inovações genéticas apresentaram, também, um forte impacto sobre a silvicultura brasileira, sendo classificadas como inovações tecnológicas biológicas, havendo as de processo (por exemplo, a clonagem) e as de produto (por exemplo, a obtenção de novos híbridos), grandes (pois provocaram um grande aumento na produtividade) e nacionais (pois foram realizadas no Brasil).

Também na década de oitenta, várias inovações tecnológicas ocorreram na área de produção de mudas, a qual se tornou uma operação rápida, eficiente e econômica. A produção de mudas por semeadura direta em embalagens foi, na opinião de GOMES \& COUTO $(1986$, p.9), uma das maiores inovações introduzidas na produção de mudas em grande escala.

No ano de 1986, o Brasil já dispunha de uma capacidade instalada de produção de sementes geneticamente melhoradas e selecionadas capaz de suprir a sua demanda interna. Percebia-se uma tendência para a substituição dos sacos plásticos por tubetes de plástico rígido, na produção de mudas. A produção de mudas por meio da semeadura

15 Através dos quais uma árvore que apresentasse, comprovadamente, um material genético superior no que se refere à resistência contra pragas e doenças, qualidade da madeira, produtividade, entre outras, poderia ser reproduzida com exatidão, isto é, a partir de uma única árvore considerada superior poder-se-ía obter milhares de mudas geneticamente idênticas. 
direta em embalagens, por exemplo, passou a ser feita pelas grandes empresas reflorestadoras através de sistemas mecanizados utilizando agulhas injetoras de sementes, os quais podiam produzir 200.000 mudas por dia, ficando as mudas prontas para o plantio no campo em 90 dias. Estas inovações na área de produção de mudas podem ser classificadas como inovações tecnológicas agronômicas de processo, sendo grandes inovações (pois geraram grandes aumentos de produtividade).

Ainda na década de oitenta, houve uma outra expansão na área de adubação - a maior já apresentada - com um grande aumento de inovações tecnológicas incorporadas aos sistemas de produção (novos aspectos relacionados à calagem, à gessagem, novas dosagens usadas na adubação, novos elementos químicos utilizados, bem como novas fontes desses elementos). De certa forma, isto se deveu ao aumento da conscientização sobre a necessidade e importância da realização da adubação para a obtenção de maiores produtividades.

A Tabela 3 apresenta informações sobre o uso de adubos (químicos e orgânicos), corretivos (calcários e outros) e defensivos (inseticidas, fungicidas, herbicidas, etc.) pelos estabelecimentos silvicultores, segundo as informações dos Censos Agropecuários.

TABELA 3 - PERCENTAGEM DE ESTABELECIMENTOS SILVICULTORES QUE USAM ADUBOS, CORRETIVOS E DEFENSIVOS

\begin{tabular}{c|c|c|c|c}
\hline ANO & Total de Estabelecimentos & Usam Adubos & $\begin{array}{c}\text { Usam } \\
\text { Corretivos }\end{array}$ & $\begin{array}{c}\text { Usam } \\
\text { Defensivos }\end{array}$ \\
\hline 1970 & 8.840 & $29,49 \%$ & $6,10 \%$ & - \\
\hline 1975 & 9.746 & $33,01 \%$ & $6,46 \%$ & $37,46 \%$ \\
\hline 1980 & 11.139 & $29,58 \%$ & $6,74 \%$ & $35,78 \%$ \\
\hline 1985 & 15.263 & $37,12 \%$ & $7,35 \%$ & $35,58 \%$ \\
\hline
\end{tabular}

FONTES: $\quad$ Censos Agropecuários do Brasil de 1970, 1975, 1980 e 1985.

No que se refere à adubação, como já mencionamos, após 1974, houve um grande desenvolvimento das pesquisas, das inovações tecnológicas ocorridas e da difusão destas inovações. Isto foi explicado pela baixa fertilidade das novas áreas ocupadas, que contribuiu para baixas produtividades, fazendo com que a importância do uso da 
adubação fosse ressaltada. De fato, os dados da Tabela 3 mostram que a percentagem dos estabelecimentos silvicultores que usavam adubação passou de $29,49 \%$, em 1970 , para 33,01\%, em 1975 .

O aumento dos preços dos adubos e o aumento do número total de estabelecimentos silvicultores (dentre os quais, devido a condições técnicas e/ou financeiras, alguns com sistemas de produção mais atrasados) provocaram a diminuição, verificada em 1980, da percentagem do total de estabelecimentos silvicultores que usavam a adubação (o que não significa que a área total adubada foi diminuída). Contudo, também como já mencionamos, uma maior conscientização sobre a necessidade da adubação ocorreu na década de 80 , o que acabou refletindo-se sobre a pesquisa e o implemento de inovações tecnológicas. Assim, em 1985, percebemos que houve, novamente, um aumento da percentagem dos estabelecimentos que usavam a adubação.

É importante dizer que em 1985 - ainda com os dados dos Censos Agropecuários do Brasil - pela primeira vez, a percentagem do total de estabelecimentos silviculturais que usavam a adubação orgânica supera a percentagem dos que usavam a adubação química, fato este que reafirma a possivel tendência, discutida anteriormente, de procura por alternativas mais ecológicas e eficientes.

Quanto aos corretivos, apesar da pouca importância que foi dada à sua utilização, podemos dizer que houve pequenos aumentos da percentagem dos estabelecimentos silvicultores que os utilizavam entre 1970 e 1985.

Quanto ao uso de defensivos, podemos dizer que o aumento dos problemas com pragas, doenças e plantas daninhas (que incentivavam o aumento dos trabalhos de pesquisa), fez com que $37,46 \%$ do total de estabelecimentos silvicultores, em 1975, usassem algum tipo de fungicida, herbicida, etc.. Entretanto, alguns fatores - como o alto custo desses defensivos, bem como alguns danos ao ambiente provocados por eles, além da introdução de outras inovações tecnológicas (como, por exemplo, o uso de espécies resistentes a certas pragas e doenças, o manejo integrado de pragas, o controle biológico, etc.) nos sistemas de produção - fizeram com que verificássemos uma pequena diminuição da percentagem dos estabelecimentos silviculturais que usavam defensivos na segunda metade da década de setenta e na primeira metade da década de oitenta (esta 
percentagem era de $37,46 \%$, em 1975 , e passou a $35,78 \%$, em 1980 , e a $35,58 \%$, em 1985).

De qualquer forma, o uso de produtos químicos ainda era, e continua sendo, a forma de proteção contra pragas, doenças e plantas daninhas mais encontrada nos sistemas de produção do eucalipto e do pinus, sendo que isto deve-se à sua eficácia e praticidade, principalmente nas grandes áreas reflorestadas.

As inovações ocorridas na área de adubação, corretivos e defensivos podem ser classificadas como inovações tecnológicas químicas, havendo tanto as de processo quanto as de produto, sendo consideradas grandes inovações (pois provocaram grandes aumentos de produtividade).

É importante destacar que na década de oitenta, todas as áreas e segmentos de pesquisa foram explorados, sendo várias inovações tecnológicas, de diversos graus de importância, incorporadas aos sistemas de produção.

As inovações ocorridas na área gerencial foram diversificadas, sendo alguns avanços obtidos em segmentos tais como especialização de serviços, informática, inventário florestal, análise de viabilidade econômica, etc.. Foram inovações tecnológicas gerenciais e de processo (por exemplo, novos métodos de treinamento).

Segundo CARDONA (1992, p.44 - 46), a mecanização das operações florestais (no final da década de oitenta) encontrava-se num estágio intermediário, atrasada de 15 a 20 anos em relação a uma filosofia de mecanização compatível com níveis de primeiro mundo. Porém, esta mecanização era maior do que tínhamos no periodo anterior à concessão dos incentivos fiscais ao florestamento e reflorestamento. As Tabelas 4 e 5 permitem-nos observar - a partir dos dados dos Censos Agropecuários - as tendências que existiram na silvicultura brasileira, no que se refere à força utilizada nos trabalhos e às classes de potência dos tratores agrícolas usados. 
TABELA 4 - USO E PROCEDÊNCIA DA FORÇA UTHIZADA NOS TRABALHOS REALIZADOS NA SILVICULTURA.

\begin{tabular}{c|c|c|c|c}
\hline \multirow{2}{*}{ ANO } & \multirow{2}{*}{ Total de Estabelecimentos } & \multicolumn{3}{|c}{ Estabelecimentos Informantes } \\
\cline { 3 - 5 } & & Total & \multicolumn{2}{|c}{ Tipo } \\
\cline { 3 - 5 } & & 3.496 & $\begin{array}{c}1.999 \\
(22,61 \%)\end{array}$ & $\begin{array}{c}1.044 \\
(11,81 \%)\end{array}$ \\
\hline 1970 & 8.840 & & 2.670 & 2.276 \\
& & $4.678^{*}$ & $(27,40 \%)$ & $(23,35 \%)$ \\
\hline 1975 & 9.746 & $4.893^{*}$ & 2.299 & 3.339 \\
& & & $(20,64 \%)$ & $(29,98 \%)$ \\
\hline 1980 & 11.139 & $6.855^{*}$ & 4.057 & 4.279 \\
& & & $(26,58 \%)$ & $(28,04 \%)$ \\
\hline 1985 & 15.263 & &
\end{tabular}

FONTES: Censos Agropecuários do Brasil de 1970, 1975, 1980 e 1985.

NOTA : ${ }^{*}$ inclui estabelecimentos que declararam mais de um tipo de força utilizada.

Através da Tabela 4, notamos que, em 1970, apenas $11,81 \%$ do número total de estabelecimentos silvicultores utilizavam força do tipo mecânica, sendo este tipo de força menos usada que a animal (que era empregada em $22,61 \%$ do número total dos estabelecimentos silvicultores em 1970). Além do mais, ainda de acordo com a mesma fonte, podemos mencionar que a porcentagem de estabelecimentos silvicultores que utilizavam forças do tipo mecânica e animal, isoladamente e em conjunto - que representavam $39,55 \%$ do total - era menor que a percentagem de estabelecimentos que utilizavam exclusivamente a força do tipo humana $(60,45 \%)$.

Através dos Censos Agropecuários do Brasil de 1975 e 1980, percebemos que na década de setenta houve um aumento do número de estabelecimentos que utilizavam força mecânica em relação ao número total de estabelecimentos silvicultores. Em 1980, a percentagem de estabelecimentos silvicultores que utilizavam força mecânica $(29,96 \%)$ era, pela primeira vez, maior que a percentagem dos estabelecimentos que usavam a força animal $(20,64 \%)$, sendo que esta tendência pode ter sido devida ao fornecimento de crédito subsidiado para investimentos na área de mecanização.

Em 1985, devido às deficiências técnicas na área de mecanização enfrentadas pela silvicultura brasileira (falta de uma tecnologia nacional, por exemplo) e/ou às dificuldades econômicas enfrentadas pelos estabelecimentos silvicultores, a percentagem de 
estabelecimentos silvicultores que utilizavam força mecânica teve uma pequena queda em relação a 1980 , passando de $29,96 \%$ em 1980 para $28,04 \%$ em 1985 . Outro fato importante é que em 1985, houve um aumento considerável do número de estabelecimentos silvicultores que utilizavam força animal em relação ao ano de 1980. Entretanto, devemos mencionar que a Tabela 4 considera apenas o número de estabelecimentos silvicultoras, sendo que assim pode ter havido uma diminuição na percentagem de estabelecimentos com uso de força mecânica simultaneamente com um aumento da proporção da área que é explorada com a utilização deste tipo de força.

Com as informações dos Censos Agropecuários do Brasil de 1970, 1975 e 1980, podemos verificar (através da Tabela 5) que estava havendo, na silvicultura brasileira deste período, um incremento do uso de tratores de maiores potências (maiores que 50 CV) entre os estabelecimentos silvicultores e uma diminuição da percentagem de estabelecimentos que usavam tratores com potências menores que $50 \mathrm{CV}$. Os tratores de potências menores de $50 \mathrm{CV}$, por exemplo, que em 1970 representavam $41,67 \%$ do total de tratores em uso na silvicultura, passaram a representar apenas $24,07 \%$ do total de tratores em uso em 1975 e $21,57 \%$ em 1980. Já os tratores de potências maiores que 50 CV passaram de $58,33 \%$ em 1970 , para $75,93 \%$ do total de tratores em 1975 , e para 78,43\%, em 1980. Este fenômeno pode ser explicado pela grande expansão da área reflorestada bem como pelo aumento do volume de madeira por área explorada ocorridas neste período, além de uma possível influência da tecnologia importada.

TABELA 5 - PERCENTAGEM DE TRATORES AGRÍCOLAS USADOS NA SILVICULTURA SEGUNDO A CLASSE DE POTÊNCIA.

\begin{tabular}{c|c|c|c|c|c}
\hline \multirow{2}{*}{ ANO } & \multirow{2}{*}{$\begin{array}{c}\text { Número total } \\
\text { de tratores } \\
\text { em uso }\end{array}$} & $\begin{array}{c}\text { menos de } \\
10 \mathrm{CV}\end{array}$ & $\begin{array}{c}\text { de } 10 \mathrm{CV} \text { a } \\
\text { menos de } 50 \\
\mathrm{CV}\end{array}$ & $\begin{array}{c}\text { de } 50 \mathrm{CV} \text { a } \\
\text { menos de } \\
100 \mathrm{CV}\end{array}$ & $\begin{array}{c}100 \mathrm{CV} \text { e } \\
\text { mais }\end{array}$ \\
\hline 1970 & 1.783 & $8,58 \%$ & $33,09 \%$ & $49,64 \%$ & $8,69 \%$ \\
\hline 1975 & 3.557 & $5,57 \%$ & $18,50 \%$ & $56,03 \%$ & $19,90 \%$ \\
\hline 1980 & 3.885 & $2,93 \%$ & $18,64 \%$ & $51,48 \%$ & $26,95 \%$ \\
\hline 1985 & 5.316 & $5,19 \%$ & $19,24 \%$ & $53,25 \%$ & $22,32 \%$ \\
\hline
\end{tabular}

FONTES: Censos Agropecuários do Brasil de 1970, 1975, 1980 e 1985. 
O Censo Agropecuário de 1985, entretanto, já mostrou um cenário diferente. Houve uma diminuição, comparando-se com o ano de 1980, na porcentagem de tratores com potências maiores que $100 \mathrm{CV}$. Todas as outras classes de potência apresentavam um aumento de suas percentagens em relação ao ano de 1980. Isto pode ser explicado pela especialização de operações que estava ocorrendo na silvicultura (ou seja, as diversas operações realizadas na silvicultura passaram a apresentar métodos e equipamentos próprios visando uma melhoria na eficiência) e pelo próprios motivos que impulsionam ou retraem a mecanização como um todo (disponibilidade técnica, econômica, etc.).

A Tabela 6 apresenta algumas informações sobre irrigação.

TABELA 6 - PERCENTAGEM DE ESTABELECIMENTOS SILVICULTORES QUE USAM A IRRIGAÇÃO E PERCENTAGEM DA ÁREA TOTAL QUE É IRRIGADA.

\begin{tabular}{c|c|c|c|c}
\hline ANO & Total de Estabelecimento & $\begin{array}{c}\text { Usam } \\
\text { Irrigação }\end{array}$ & $\begin{array}{c}\text { Área Total } \\
\text { (ha) }\end{array}$ & $\begin{array}{c}\text { Área Irrigadal } \\
\text { Área Total }\end{array}$ \\
\hline 1970 & 8.840 & $1,69 \%$ & 2.758 .241 & $0,13 \%$ \\
\hline 1975 & 9.746 & $2,05 \%$ & 4.987 .686 & $1,02 \%$ \\
\hline 1980 & 11.139 & $1,91 \%$ & 7.387 .598 & $0,36 \%$ \\
\hline 1985 & 15.263 & $1,83 \%$ & 8.735 .324 & $0,11 \%$ \\
\hline
\end{tabular}

FONTES: $\quad$ Censos Agropecuários do Brasil de 1970, 1975, 1980, 1985.

A irrigação foi e é uma prática pouco utilizada na silvicultura brasileira, restringindo-se às áreas de canteiros de mudas. Através dos dados da Tabela 6, observamos uma ampliação absoluta e relativa no uso da irrigação em estabelecimentos silvicultores entre os anos de 1970 e 1975. Esta tendência, no entanto, foi revertida, sendo que nos anos de 1980 e 1985 percebemos que houve uma redução no uso da irrigação. Provavelmente, isto ocorreu porque um novo sistema de produção de mudas começou a ser implementado, no qual um número muito maior de mudas era produzido em áreas muito menores. 
Atualmente, podemos dizer que, de modo geral, o Brasil atingiu uma posição destacada em relação a outros países no que diz respeito à tecnologia silvicultural, chegando a exportar tecnologia para alguns países, entre os quais a Austrália (local de origem do eucalipto). $\mathrm{O}$ nivel tecnológico relativamente avançado e o impacto causado pelo fim dos incentivos fiscais ao reflorestamento/florestamento, ocorrido em 1988, podem ter sido responsáveis por uma nova tendência que passou a ser verificada na evolução tecnológica da silvicultura brasileira. Assim sendo, já a partir do final da década de oitenta, podemos perceber uma tendência de atribuição de uma crescente importância às áreas de pesquisas que proporcionassem inovações que apresentassem a característica comum de diminuírem os custos, melhorarem a qualidade, aumentarem a produtividade, etc.. Tudo isto de forma acentuada, visando uma máxima eficiência que, por sua vez, proporcionaria maior competitividade.

Através da leitura de revistas técnicas e informativas sobre a silvicultura (como, por exemplo, a Revista Silvicultura) e de conversas com técnicos envolvidos com esta atividade, pudemos observar que as inovações ocorridas a partir do final da década de oitenta foram: aplicação de várias novas técnicas em biotecnologia, o implemento do uso de adubação alternativa (resíduos industriais, compostos orgânicos), a utilização do método de manejo integrado de pragas e doenças, o uso de um novo sistema de produção de mudas (que apresenta usos múltiplos, isto é, sistema que é utilizado o ano todo para a produção de mudas de diversas culturas), o uso de sistemas mecanizados portáteis para produção de mudas visando auxiliar pequenos silvicultores, a utilização crescente da informática, a introdução de uma série de medidas visando a proteção ambiental, a realização de cultivo mínimo do solo no preparo da área para o plantio, o desenvolvimento na área de mecanização (principalmente, devido ao processo de abertura de mercado). Infelizmente, não existem dados globais que quantificam o uso dessas novas tecnologias. 


\section{CAPÍTULO 3}

\section{A IMPORTÂNCIA DAS INOVAÇÕES TECNOLÓGICAS NA EXPANSÃo DA SILVICULTURA BRASILEIRA}

A finalidade deste capítulo é analisar o impacto das inovações tecnológicas sobre a expansão da silvicultura brasileira (sendo que esta expansão é medida pela expansão da área reflorestada/florestada). Para isto, uma equação da área reflorestada/florestada é estimada, onde o papel das inovações tecnológicas sobre esta expansão é avaliado.

A relação entre inovação tecnológica e expansão da silvicultura brasileira é estabelecida através da produtividade. Em geral, podemos dizer que a evolução tecnológica ocorrida na silvicultura brasileira provocou um aumento geral da produtividade que, por sua vez, reduziu os custos do reflorestamento/florestamento. Esta redução elevou a rentabilidade da silvicultura, causando a sua expansão. Assim, na equação da área reflorestada, a variável produtividade mede o papel da inovação tecnológica na expansão da silvicultura brasileira verificada a partir de 1970.

No item 3.1, estabelecemos uma relação entre inovação tecnológica, produtividade e custo. Além disso, mostramos a evolução da produtividade dos plantios de eucalipto e de pinus, bem como a evolução verificada nos níveis de custos do reflorestamento/florestamento. No item 3.2, a equação da área reflorestada/florestada é desenvolvida e no item 3.3, esta equação da área reflorestada/florestada é estimada. 


\section{1 - Relação entre Inovação Tecnológica, Produtividade e Custo}

Vários autores têm mostrado que a inovação tecnológica provoca aumentos na produtividade. Entre eles, temos: HAYAME \& RUTTAN (1988), HOSSAIN \& CROUCH (1992) e PEREIRA (1991).

HAYAME \& RUTTAN (1988), baseados em SCHULTZ (1964) $)^{16}$ defenderam, em seu trabalho, a hipótese de que para obter sucesso e alcançar crescimento rápido na produtividade agrícola, é necessária uma capacidade de gerar tecnologias agrícolas adaptadas ecológica e economicamente a cada região.

HOSSAIN \& CROUCH (1992), com uma análise de regressão, mostraram que em Bangladesh a produtividade da terra surgiu como o mais importante sinal da adoção de novas tecnologias pelos fazendeiros.

PEREIRA (1991), estudando o caso de Minas Gerais, afirma que os avanços tecnológicos alteram as estruturas do processo de produção, modificando a produtividade fisica.

$\mathrm{Na}$ agricultura e na silvicultura, podemos definir três tipos de produtividade: produtividade da mão-de-obra, produtividade de equipamentos e produtividade da terra. Contudo, a produtividade mais comumente usada nas análises e estudos da silvicultura e até mesmo da agricultura como um todo - devido à disponibilidade de informações e/ou à grande capacidade que este tipo de produtividade possui de representar os fenômenos ocorridos - é a produtividade da terra, sendo, por isto, o tipo de produtividade utilizado na nossa análise.

A produtividade da terra é a que expressa a quantidade de produto obtida numa determinada área, durante determinado período de tempo. No caso da silvicultura, por exemplo, a produtividade da terra é medida em estéreos/hectare/ano ${ }^{17}$ e depende,

\footnotetext{
${ }^{16}$ SCHULTZ, T.W. (1964) Transforming Traditional Agriculture, New Haven: Yale University Press, 1964, p. 145-147.

17 Estéreo ou estere é uma unidade de volume obtida por um sistema simples de empilhamento da madeira com vãos provocados pela tortuosidade das peças. Via de regra, 100 estéreos correspondem a 75 metros cúbicos.
} 
essencialmente, do ambiente e do potencial genético da espécie ou das espécies que compõem estas áreas.

As inovações tecnológicas tornam-se importantes na determinação da produtividade à medida que provocam mudanças no ambiente (como, por exemplo, o desenvolvimento na área de adubação melhorando os níveis de fertilidade do solo), bem como quando proporcionam um melhoramento genético nas espécies em questão (como, por exemplo, métodos de polinização controlada produzindo hibridos geneticamente superiores sob vários aspectos). Contudo, a grande diversidade de como esses fatores apresentam-se nas diferentes áreas reflorestadas/florestadas no Brasil, ou seja, as variações determinadas pelos diferentes ambientes, diferentes materiais genéticos e diferentes níveis tecnológicos, aliados às diferenças nas épocas consideradas na determinação da produtividade, fazem com que seja dificil adotar níveis médios de produtividade para o eucalipto e para o pinus nas diferentes fases da evolução da silvicultura brasileira. BERGER (1979), em 1979, já salientava a falta de dados sobre produtividade de eucalipto e pinus e mencionava vários motivos para fazermos médias sobre os rendimentos destes dois gêneros para a realização de análises.

De acordo com dados de empresas consultadas e da literatura existente (descritos no Apêndice B - Evolução da Produtividade na Silvicultura Brasileira) e tentando chegar o mais próximo possível dos níveis de produtividade que caracterizem da melhor forma possivel as diferentes fases da evolução da silvicultura brasileira, construímos a Tabela 7 .

A produtividade média da silvicultura brasileira que aparece na Tabela 7 foi obtida ponderando-se as produtividades médias dos gêneros Eucalyptus e Pinus pelas respectivas áreas reflorestadas/florestadas, cujos dados são encontrados em relatórios do extinto Instituto Brasileiro de Desenvolvimento Florestal (IBDF) - período de 1968 a 1986 - e nos anuários da Associação Nacional dos Fabricantes de Papel e Celulose período de 1987 a 1993. Devido à disponibilidade de informções, a Tabela 7 apresenta algumas limitações (veja Apêndice B), entretanto, devemos deixar destacado o caráter inovador desses dados. 
TABELA 7 - EVOLUÇÃO DA PRODUTIVIDADE MÉdIA DO EUCALIPTO, DO PINUS E DA SILVICULTURA BRASILEIRA

\begin{tabular}{|c|c|c|c|}
\hline \multirow{2}{*}{ Ano } & \multicolumn{3}{|c|}{ Produtividade Média (estéreos/hectare/ano) } \\
\hline & Eucalipto & Pinus & Silvicultura Brasileira \\
\hline 1960 & 12,50 & & \\
\hline 1961 & $13,06^{*}$ & & \\
\hline 1962 & $13,65^{*}$ & & \\
\hline 1963 & $14,26 *$ & & \\
\hline 1964 & $14,90^{*}$ & & \\
\hline 1965 & $15,57^{*}$ & & \\
\hline 1966 & $16,27^{*}$ & & \\
\hline 1967 & 17,00 & & \\
\hline 1968 & 17,50 & 20,00 & 19,17 \\
\hline 1969 & $18,17^{*}$ & $20,00^{*}$ & 19,35 \\
\hline 1970 & $18,87^{*}$ & 20,00 & 19,54 \\
\hline 1971 & 19,60 & $21,00^{*}$ & 20,20 \\
\hline 1972 & $20,11^{*}$ & 22,00 & 20,81 \\
\hline 1973 & $20,62 *$ & $22,26^{*}$ & 21,19 \\
\hline 1974 & $21,16^{*}$ & $22,52^{*}$ & 21,58 \\
\hline 1975 & 21,70 & $22,78^{*}$ & 22,02 \\
\hline 1976 & $24,08^{*}$ & $23,05^{*}$ & 23,82 \\
\hline 1977 & 26,70 & $23,32^{*}$ & 25,56 \\
\hline 1978 & 27,90 & $23,59 *$ & 26,26 \\
\hline 1979 & $29,19^{*}$ & $23,86^{*}$ & 27,62 \\
\hline 1980 & $30,55^{*}$ & $24,14 *$ & 28,97 \\
\hline 1981 & $31,97^{*}$ & $24,43^{*}$ & 29,42 \\
\hline 1982 & $33,45^{*}$ & $24,71^{*}$ & 29,44 \\
\hline 1983 & 35,00 & 25,00 & 30,53 \\
\hline 1984 & $35,95^{*}$ & $26,35^{*}$ & 32,47 \\
\hline 1985 & $36,92^{*}$ & $27,77^{*}$ & 33,87 \\
\hline 1986 & $37,92^{*}$ & $29,26^{*}$ & 35,08 \\
\hline 1987 & $38,95^{*}$ & $30,84^{*}$ & 36,27 \\
\hline 1988 & 40,00 & 32,50 & 37,98 \\
\hline 1989 & $41,00^{*}$ & $33,31^{*}$ & 39,62 \\
\hline 1990 & 42,00 & $34,15^{*}$ & 40,98 \\
\hline 1991 & 46,00 & 35,00 & 43,99 \\
\hline 1992 & 43,00 & 33,00 & 41,36 \\
\hline 1993 & 43,00 & 34,00 & 41,07 \\
\hline
\end{tabular}

FONTE: Vários autores, veja Apêndice B.

* Valores obtidos através de interpolação, isto é, se existe um dado no período $t-k\left(D_{t-k}\right)$ e outro no período $t\left(D_{t}\right)$ o valor no período $t-k+n$ é $D_{t-k+n}=\left(\sqrt[k]{\frac{D_{t}}{D_{t-k}}}\right)^{n} \cdot D_{t-k}$. 
Através da Tabela 7, podemos observar que o aumento verificado nos níveis de produtividade do eucalipto e do pinus nos últimos vinte e cinco anos foi marcante. Este aumento da produtividade é devido, basicamente, ao processo de evolução tecnológica ocorrido na silvicultura brasileira, que alterou $o$ ambiente das áreas reflorestadas/florestadas e/ou ampliou o potencial genético das espécies utilizadas. Além disso, este processo de evolução tecnológica teve influência sobre os custos do reflorestamento/florestamento.

Segundo BREPOHL (1980), o custo total, num estabelecimento florestal, pode ser decomposto em: custo da mão-de-obra, custo de materiais, custos de serviços de terceiros, custos de depreciação, custo financeiro, impostos e taxas. Este autor ainda cita SPEIDEL (1967) ${ }^{18}$, que acrescenta a esses tipos de custo um custo de risco, que seria o de todas as perdas de valor devido a acontecimentos não previsíveis, como incêndios, pragas, doenças e outros.

Como já comentado anteriormente, as inovações tecnológicas ocorridas na silvicultura brasileira determinaram aumentos nos níveis de produtividade em geral (produtividade da terra, da mão-de-obra e de equipamentos). Se o aumento da produtividade de um fator (estéreos/hectare, por exemplo) deu-se numa situação onde não houve redução da produtividade de nenhum outro fator e onde os preços reais dos insumos e dos fatores de produção (terra, mão-de-obra, fertilizantes, defensivos, mudas, etc.) não variam, podemos dizer que, em decorrência das inovações tecnológicas, houve uma redução do custo real por unidade do produto (custo por estéreo de madeira, por exemplo). Para ilustrarmos esta situação, podemos mencionar uma inovação tecnológica ocorrida na década de setenta, que consistiu na escolha das espécies/procedências mais indicadas para cada ambiente específico, que proporcionou aumentos de até $50 \%$ na produtividade do eucalipto e do pinus e não provocou alterações significativas nos sistemas de produção. Se esta situação tiver ocorrido num ambiente de preços reais constantes de insumos e fatores de produção, teremos um mesmo custo por área

${ }^{18}$ SPEIDEL, G. (1967) Economia Florestal,Universidade Federal do Paraná, Curitiba, 1967, p.54. 
(custo/hectare). Além disso, como houve um aumento de produtividade, podemos dizer que acontece uma redução dos custos por estéreo.

Um outro fator que afeta os custos de produção de um estéreo de madeira é o preço real dos insumos e dos fatores de produção. No caso da produtividade fisica permanecer a mesma e os preços reais dos insumos diminuírem, temos uma redução no custo real por estéreo de madeira.

$\mathrm{Na}$ vida real, temos os dois elementos que afetam os custos por estéreo (variações da produtividade e dos preços reais dos insumos e dos fatores de produção) atuando juntos.

$\mathrm{Na}$ Tabela 8, compilamos alguns dados sobre a evolução ocorrida na silvicultura brasileira em termos de níveis de custo de implantação e manutenção de florestas plantadas com Eucalyptus spp e Pinus spp, segundo determinados níveis de produtividade esperados. 
TABELA 8 - EVOLUÇÃO DO CUSTO DE IMPLANTAÇÃO E MANUTENÇÃO DE FLORESTAS DE EUCALYPTUS SPP E PINUS SPP

\begin{tabular}{c|c|c|c|c}
\hline Ano & $\begin{array}{c}\text { Custo/hectare } \\
\text { (valores } \\
\text { nominais) }\end{array}$ & $\begin{array}{c}\text { Custo/hectare } \\
\text { (em Dólares de } \\
\text { dezembro } \\
\text { 1992/hectare) }\end{array}$ & $\begin{array}{c}\text { Produtividade } \\
\text { Esperada } \\
\text { (estéreos/hectare/ } \\
\text { ano) }\end{array}$ & $\begin{array}{c}\text { Custo/estéreo } \\
\text { (em Dólares de } \\
\text { Dezembro } \\
\text { 1992/estéreo) }\end{array}$ \\
\hline 1967 & 780 & $1.104,69$ & 15,5 & 3,56 \\
1968 & 932 & $1.062,66$ & 15,5 & 3,43 \\
1969 & 1.090 & $1.034,37$ & 15,5 & 3,34 \\
1970 & 1.606 & $1.276,31$ & 15,5 & 4,12 \\
1971 & 1.849 & $1.221,28$ & 15,5 & 3,94 \\
1972 & 2.279 & $1.283,80$ & 24,0 & 2,67 \\
1973 & 2.776 & $1.283,80$ & 24,0 & 2,83 \\
1974 & 3.914 & $1.359,46$ & 24,0 & 3,10 \\
1975 & 6.045 & $1.490,09$ & 24,0 & 3,75 \\
1976 & 7.212 & $1.798,93$ & 24,0 & 3,17 \\
1977 & 8.680 & $1.282,42$ & 24,0 & 2,67 \\
1986 & 12.202 & $1.597,13$ & 35,0 & 2,28 \\
\hline
\end{tabular}

FONTES: Informações de 1967 a 1977 retiradas de BEATTIE \& FERREIRA (1978) Informação de 1986 referente ao Estado de São Paulo e retirada de TOLEDO et alii (1987)

NOTA: O custo/estéreo foi calculado dividindo-se os custos/hectare anuais (os valores nominais foram deflacionados pelo IGP-DI e transformados em dólar de dezembro de 1992) do reflorestamento/florestamento (implantação e manutenção de florestas - média brasileira para os gêneros Eucalyptus e Pinus) pelas respectivas produtividades médias esperadas para os níveis de tecnologia empregados num período de 20 anos.

Através da Tabela 8, percebemos dois fatos importantes: o primeiro é que, em determinados anos, mesmo para níveis de produtividades esperados constantes (caso de 1967 a 1971, por exemplo) - o que faz presumir níveis tecnológicos semelhantes, isto é, não considerando incorporação de inovações tecnológicas aos sistemas de produção no decorrer desses anos - houve variações nos custos/estéreo; o segundo fato importante é que comparando os custos/estéreo de 1967 a 1986, constatamos que, mesmo para maiores produtividades esperadas (resultantes da incorporação de inovações tecnológicas aos sistemas de produção e/ou do uso de maior quantidade de insumos), houve anos em que os custos/estéreo (1975, por exemplo) superaram os custos/estéreo de anos onde a 
produtividade esperada era menor (anos onde, teoricamente, os níveis tecnológicos eram menos evoluídos, como 1969, por exemplo).

Estes dois fatos extraídos da Tabela 8 podem ser explicados por possíveis variações nos preços reais dos insumos e dos fatores de produção utilizados no reflorestamento/florestamento, pois quando mencionamos que as inovações tecnológicas provocam aumentos nos níveis de produtividade em geral e, conseqüentemente, com isto, diminuem os custos/estéreo, causando um impacto sobre a área reflorestada/florestada e sobre a silvicultura como um todo, consideramos a hipótese de que os preços reais dos insumos e dos fatores de produção eram constantes ou que aumentavam de maneira menos que proporcional ao aumento da produtividade. Entretanto, a Tabela 8 evidenciou a necessidade de considerarmos, também, a situação em que esses preços reais de insumos e fatores de produção não são constantes, isto é, a situação em que variações dos preços reais dos insumos e dos fatores de produção podem afetar os custos do reflorestamento/florestamento e, conseqüentemente, influenciar a silvicultura no período em análise.

Para avaliarmos a situação em que os preços reais dos insumos e dos fatores de produção utilizados no reflorestamento/florestamento não são constantes, construímos a Tabela 9. Os custos do reflorestamento/florestamento (em Dólares de Dezembro de 1992) foram calculados considerando um mesmo sistema de produção (portanto, com níveis de produtividade esperada constantes) para o período de 1969 a 1986 . Assim, as variações de custos surgem somente da variação dos preços reais de alguns insumos e fatores de produção utilizados no reflorestamento/florestamento (caso do arrendamento da terra, mão-de-obra, mudas, horas de equipamento, defensivos e adubos) e não da evolução tecnológica ocorrida na silvicultura brasileira (veja o Apêndice C).

Os dados da Tabela 9 demonstram uma tendência de alta no custo do reflorestamento/florestamento (supondo um nível de produtividade constante) para o período compreendido entre 1969 e 1975, seguida de uma flutuação dos custos com tendência de redução de 1976 a 1983; e alta em 1984, 1985 e 1986.

Contudo, somente as variações nos custos não explicam as variações na área reflorestada/florestada. Com base em PEREIRA (1991), podemos dizer que em 
condições reais, os distúrbios econômicos provocados por mudanças nos níveis de preços dos fatores podem ser contornados pela substituição desses fatores no sentido de que a eficiência seja recomposta (e é neste caso que as inovações tecnológicas tornam-se importantes). Assim, os dados da Tabela 9 serão combinados com os dados da Tabela 7 para explicarem os efeitos das inovações tecnológicas e dos preços relativos dos insumos e dos fatores de produção sobre a expansão da área reflorestada/florestada no Brasil.

TABELA

9

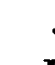

DO

CUSTO

DO REFLORESTAMENTO/FLORESTAMENTO SUPONDO SISTEMA DE PRODUÇÃO CONSTANTE E NÍVEL DE PRODUTIVIDADE ESTÉREOS/HECTARE/ANO).

\begin{tabular}{|c|c}
\hline Ano & $\begin{array}{c}\text { Custo/Hectare (em Dólares de Dezembro } \\
\text { de 1992) }\end{array}$ \\
\hline 1969 & $3.648,60$ \\
\hline 1970 & $3.749,36$ \\
\hline 1971 & $3.869,15$ \\
\hline 1972 & $4.336,23$ \\
\hline 1973 & $5.008,08$ \\
\hline 1974 & $5.581,34$ \\
\hline 1975 & $5.738,44$ \\
\hline 1976 & $5.306,82$ \\
\hline 1977 & $5.079,68$ \\
\hline 1978 & $5.267,56$ \\
\hline 1979 & $5.144,03$ \\
\hline 1980 & $5.146,38$ \\
\hline 1981 & $5.224,56$ \\
\hline 1982 & $5.248,45$ \\
\hline 1983 & $4.780,31$ \\
\hline 1984 & $4.929,36$ \\
\hline 1985 & $5.503,55$ \\
\hline 1986 & $5.764,12$ \\
\hline
\end{tabular}




\section{2 - A Equação da Área Reflorestada/Florestada}

Após a descrição e análise das inovações tecnológicas ocorridas na silvicultura brasileira bem como das relações que existem entre estas inovações e a evolução da produtividade e a evolução do custo, tanto para o eucalipto quanto para o pinus, estudamos o impacto dessas inovações tecnológicas sobre a expansão da área reflorestada/florestada e, conseqüentemente, sobre a silvicultura como um todo. Isto é feito considerando uma equação nerloviana de expansão da área reflorestada.

Segundo HOFFMANN e VIEIRA (1987, p.270), "na análise econométrica de séries temporais, é comum serem adotados modelos em que aparecem variáveis defasadas, isto é, o valor $Y_{t}$, referente ao t-ésimo periodo, aparece como função de $X_{t}$, $X_{t-1}, X_{t-2}$ e/ou $Y_{t-1}$, etc.". Ainda segundo estes mesmos autores, um modelo com variável defasada - proposto por NERLOVE $(1958)^{19}$ - tem sido bastante utilizado em estudos de oferta de produtos agrícolas (ou aumento da área plantada).

Conforme ALMEIDA (1994, p.56) "o modelo de estimação da oferta de produtos agrícolas desenvolvido por Nerlove é da categoria dos modelos de defasagens distribuídas. Quando $Y$ aparece em função de $X$, em vários momentos anteriores, diz-se que $X$ influencia $Y$ com defasagens distribuídas.

Esse modelo parte da combinação de duas hipóteses: a formação das expectativas adaptadas aos preços relativos e a mobilidade dos fatores de produção".

De acordo com MONTEIRO (1975) ${ }^{20}$, citado por ALMEIDA (1994, p.56), e BARROS (1987, p.219), podemos dizer que a existência de defasagens distribuídas se deve a três reações distintas do produtor: Defasagem Psicológica (que é o tempo que transcorre entre o momento de uma mudança e o momento de reação a esta mundança, isto devido ao hábito, ao acesso à nova informação e/ou à incerteza), Defasagem Econômica ou Tecnológica (que é o tempo necessário para mudar os ativos fixos de

19 NERLOVE, M. (1958) The Dynamics of Supply: Estimation of Farmers' Response to Price. Baltimore, John Hopkins.

${ }^{20}$ MONTEIRO, M. J. C. Modelos de Oferta Agrícola. Revista Brasileira de Economia, Rio de Janeiro, 29 (2) : 16-49, abril/junho, 1975. 
uma empresa) e Defasagem Física (que é o tempo necessário para ocorrer a variação da produção, devido às suas características biológicas).

Segundo BARROS (1987, p.274), uma variação no preço leva a dois tipos de alteração na oferta (que pode ser relacionada à alteração na área plantada). A primeira, de longo-prazo, consiste na variação desejada na produção se o novo preço persistir por um periodo de tempo suficiente para que todos os ajustamentos desejados nos fatores fixos tenham lugar. A segunda, de curto-prazo, é a alteração imediata na produção, dados os fatores fixos existentes, isto é, aquele ajustamento na produção que ocorre em $t+1$ dada a variação de preço no período $t$. Se depois dessa variação no preço, este permanecesse constante, gradualmente o completo ajuste desejado seria atingido.

ALMEIDA (1994, p.66) diz que a área cultivada pode ser a melhor variável para representar o comportamento do agricultor em função das modificações dos preços. Segundo esta autora, os modelos que utilizam a área cultivada mostram bons resultados e as diferenças com relação aos modelos que usam a quantidade produzida são pequenas, principalmente porque em algumas culturas a maior parte dos ajustamentos resultam de alteração na área cultivada.

No Brasil - como já mencionado na introdução desta dissertação - não há trabalhos que discutem os impactos das inovações tecnológicas sobre a expansão da silvicultura. Já a nível mundial, há algumas análises neste sentido (analisando a influência das inovações tecnológicas sobre a oferta de madeira especificamente ou até mesmo sobre outros produtos agrícolas). Ver NIEBUHR et alii (1990), SHERBOURNE et alii (1991), SARKAR e McKILLOP (1993), TUAZON (1993), YAO (1994), SCHULZE $e t$ alii (1994) e WANG (1994).

Mesmo não havendo trabalhos específicos analisando a influência das inovações tecnológicas sobre a expansão da silvicultura, podemos dizer que, no Brasil, vários autores desenvolveram e discutiram modelos nerlovianos para explicar a expansão da produção ou da área agrícola (ver, por exemplo, PASTORE, 1973; BARROS, 1987 e ALMEIDA, 1994). 
BACHA (1993, p. 43-45) utilizou um modelo do tipo nerloviano para determinar a equação da área reflorestada - ou seja, que explique o plantio de florestas. Em seu trabalho, este autor apresentou a equação:

$$
A_{t}=B_{0}+B_{I} \cdot P_{t-k}+B_{2} \cdot I_{t}+B_{3} \cdot A_{t-k}
$$

Onde:

$$
\begin{aligned}
& A_{t} \quad=\text { área reflorestada ou florestada observada no momento } \mathrm{t} . \\
& P p_{t-k}=\text { preço de um estéreo de madeira oriunda de mata plantada no momento } \mathrm{t}-\mathrm{k} . \\
& I_{t} \quad=\text { incentivo do governo ao reflorestamento e ao florestamento no momento } \mathrm{t} . \\
& A_{t-k} \quad=\text { área reflorestada ou florestada observada no momento } \mathrm{t}-\mathrm{k} .
\end{aligned}
$$

Esperando que $B_{1}>0, B_{2}>0$ e $B_{3}>0$

A equação (1) é a equação de curto-prazo da área reflorestada/florestada.

O trabalho de BACHA (1993) não incorporou, na equação da área reflorestada/florestada, o papel das inovações tecnológicas. Assim, no presente trabalho, pretendemos utilizar a equação nerloviana que explica o plantio de florestas - tal como BACHA (1993, p.43-45) - acrescentando duas novas variáveis explicativas (relacionadas à produtividade e aos preços reais dos insumos e fatores de produção) com o objetivo básico de determinar qual a contribuição das inovações tecnológicas na expansão da área reflorestada/florestada e, conseqüentemente, na expansão da silvicultura brasileira como um todo.

Supondo que os preços reais dos insumos e dos fatores de produção utilizados no reflorestamento/florestamento sejam constantes, podemos dizer que as inovações tecnológicas são responsáveis por aumentos nos níveis de produtividade, que por sua vez acabam provocando uma diminuição do custo por unidade do produto (custo/estéreo), 
num processo que acaba influenciando a silvicultura no sentido de expandi-la. É justamente esse processo que pretendemos avaliar com a inclusão, na equação da área reflorestada/florestada, da variável que trata da produtividade da silvicultura brasileira.

Como já discutimos no item 3.1, os preços reais dos insumos e dos fatores de produção utilizados no reflorestamento/florestamento podem variar. Essa variação, mantendo a produtividade constante, pode afetar diretamente a silvicultura brasileira através de variações nos custos. Para avaliarmos o efeito das variações dos preços reais dos insumos e dos fatores de produção sobre os custos e destes sobre a área reflorestada, incluímos na equação da área reflorestada/florestada a variável que trata dos custos do reflorestamento/florestamento, ou seja, uma variável que expressa a evolução dos custos de produção na ausência de modificações tecnológicas (veja Apêndice C).

Assim, definimos as seguintes variáveis:

$A^{*}{ }_{t}=$ área que se deseja reflorestar/florestar no momento $\mathrm{t}$.

$P p_{t-k}=$ preço de um estéreo de madeira oriunda de mata plantada no momento t-k.

$I_{t} \quad=$ incentivo do governo ao reflorestamento/florestamento no momento $\mathrm{t}$.

$\operatorname{Pr}_{t-k}=$ produtividade média da silvicultura brasileira no momento $t-\mathrm{k}^{21}$.

$C_{t-k}=$ custos do reflorestamento/florestamento no momento $\mathrm{t}-\mathrm{k}$.

Com estas variáveis, a equação de longo-prazo da área reflorestada/florestada fica da seguinte forma:

$$
A_{t}^{*}=f\left(P p_{t-k} I_{t}, \operatorname{Pr}_{t-k} C_{t-k}\right)
$$

Em termos lineares:

$$
A^{*}{ }_{t}=b_{0}+b_{1} \cdot P p_{t-k}+b_{2} \cdot I_{t}+b_{3} \cdot P_{t-k}+b_{4} \cdot C_{t-k}
$$

21 A produtividade média da silvicultura brasileira é uma média ponderada das produtividades médias do eucalipto $\mathrm{e}$ do pinus. As ponderações são as respectivas áreas reflorestadas/florestadas. 
Com:

$b_{1}>0$, ou seja, variações no preço defasado de um estéreo de madeira implicam em variações no mesmo sentido na área que se deseja reflorestar/florestar no momento t.

$b_{2}>0$, ou seja, variações nos incentivos do governo ao reflorestamento e ao florestamento implicam em variações no mesmo sentido na área que se deseja reflorestar/florestar no momento $t$.

$b_{3}>0$, ou seja, variações na produtividade defasada (momento $t-k$ ) da silvicultura brasileira implicam em variações no mesmo sentido na área que se deseja reflorestar/florestar no momento $t$.

$b_{4}<0$, ou seja, variações no custo defasado (momento t-k) do reflorestamento/florestamento (que indicam aumento dos preços reais dos insumos e fatores de produção) implicam em variações em sentido contrário na área que se deseja reflorestar/florestar no momento $t$.

A equação (3) é uma relação de comportamento que exprime a quantidade de área que se deseja reflorestar/florestar quando já tiver decorrido um período suficientemente longo (longo-prazo) para que o equilibrio seja atingido, em função dos preços da madeira, dos incentivos fiscais, da produtividade e dos preços reais dos insumos e fatores de produção. Entretanto, a área que se desejar reflorestar/florestar $\left(A^{*}\right)$, no longo-prazo, não pode ser quantificada, fazendo com que a equação (3) não possa ser estimada.

Utilizando a hipótese de ajustamento parcial proposta por Nerlove - que consiste no fato de que a área plantada (ou a produção) efetivamente obtida no ano $t$ é igual à área plantada (ou à produção) no ano $\mathrm{t}-\mathrm{k}$ mais um acréscimo que é uma proporção da variação desejada a longo-prazo - chegamos à seguinte equação: 


$$
A_{t}-A_{t-k}=j\left(A^{*}{ }_{t}-A_{t-k}\right)
$$

Onde $\mathbf{j}$ é o fator de ajustamento; $\left(A_{t}-A_{t-k}\right)$ é a mudança observada na área reflorestada/florestada (no curto-prazo); e $\left(A^{*}{ }_{t}-A_{t-k}\right)$ é a mudança desejada na área reflorestada/florestada.

Com a expressão (4), temos que a mudança observada na área reflorestada/florestada entre $\mathrm{t}-\mathrm{k}$ e $\mathrm{t}$ é uma fração $\mathrm{j}$ da mudança desejada na área reflorestada/florestada no longo-prazo. Se $\mathbf{j}=\mathbf{1}$, a área reflorestada/florestada observada é igual à área desejada. Se $\mathbf{j}=\mathbf{0}$, não houve aumento do reflorestamento/florestamento, pois $A_{t}=A_{t-k}$. De modo geral, $\mathbf{j}$ deve situar-se entre 0 e 1 , pois o ajustamento entre a área observada e a área desejada é incompleto, devido a diversas razões de funcionamento do próprio mercado.

Da expressão (4) temos :

$$
A_{t}=j \cdot A^{*}+(1-j) \cdot A_{t-k}
$$

Substituindo (3) em (5) temos:

$$
A_{t}=j \cdot b_{0}+j \cdot b_{I} P_{t-k}+j \cdot b_{2} I_{t}+j \cdot b_{3} \cdot P r_{t-k}+j \cdot b_{4} C_{t-k}+(I-j) \cdot A_{t-k}
$$

Considerando:

$B_{0}=j . b_{0} \quad B_{1}=j . b_{1} \quad B_{2}=j . b_{2} \quad B_{3}=j . b_{3} \quad B_{4}=j . b_{4} \quad B_{5}=(1-j)$, temos

$$
A_{t}=B_{0}+B_{I} P^{P}{ }_{t-k}+B_{2} \cdot I_{t}+B_{3} \cdot P_{t-k}+B_{4} \cdot C_{t-k}+B_{5} \cdot A_{t-k}
$$

Onde esperamos que $B_{1}>0, B_{2}>0, B_{3}>0, B_{4}<0$ e $B_{5}>0$. 
A equação (7) é a equação de curto-prazo da área reflorestada/florestada. Esta equação de curto-prazo será utilizada para medirmos a influência das inovações tecnológicas sobre a área reflorestada/florestada e, conseqüentemente, sobre a silvicultura brasileira.

\section{3 - Teste da Equação da Área Reflorestada/Florestada}

Para testar a equação (7), consideramos $k=1$ e utilizamos os dados de 1970 a 1986 para a área reflorestada/florestada com incentivos fiscais, o valor médio obtido com a venda de um estéreo de lenha oriunda de áreas reflorestadas/florestadas (utilizado como proxy do preço da madeira), o montante de incentivos fiscais aplicados no reflorestamento/florestamento, a produtividade média da silvicultura brasileira (dados da Tabela 7) e o valor do custo do reflorestamento/florestamento (dados da Tabela 9). Estes dados estão reunidos na Tabela 10.

O fato de utilizarmos dados de 1970 a 1986 (devido à disponibilidade de informações) pode ser considerado uma limitação, entretanto, este periodo foi caracterizado por uma grande expansão da silvicultura brasileira (grande aumento da área reflorestada), além de ser fortemente marcado pela existência de dois processos mencionados por nós: o de oferecimento de incentivos fiscais ao reflorestamento/florestamento e o de evolução tecnológica acentuada. 
TABELA 10 - ACRÉSCIMO DE ÁREA TOTAL REFLORESTADA/FLORESTADA COM INCENTIVOS FISCAIS NO BRASIL (At), ACRÉSCIMO DE ÁREA COM PINUS E REFLORESTADA/FLORESTADA COM INCENTIVOS FISCAIS NO BRASIL (Aep), PREÇOS MÉDIOS RECEBIDOS PELA LENHA ORIUNDA DA ÁREA REFLORESTADA/FLORESTADA (Pp), VALOR DOS INCENTIVOS FISCAIS AO REFLORESTAMENTO/FLORESTAMENTO (I), PRODUTIVIDADE MÉDIA DA SILVICULTURA BRASILEIRA (Pr) E CUSTOS DO REFLORESTAMENTO/FLORESTAMENTO (C)

\begin{tabular}{|c|c|c|c|c|c|c|c|}
\hline Ano & $\begin{array}{c}\text { At } \\
\text { (em } \\
\text { hectares) }\end{array}$ & $\begin{array}{c}\text { Aep } \\
\text { (em } \\
\text { hectares) }\end{array}$ & $\begin{array}{c}\text { Pp } \\
\text { (em } \\
\text { Dólares de } \\
\text { dezembro } \\
\text { 1992 por } \\
\text { st) }\end{array}$ & $\begin{array}{c}\text { I } \\
\text { (em } \\
\text { milhões de } \\
\text { Dólares de } \\
\text { dezembro } \\
\text { 1992) }\end{array}$ & $\begin{array}{l}\text { Indice } \\
\text { (para I) }\end{array}$ & $\begin{array}{c}\text { Pr } \\
\text { (em } \\
\text { estéreos } \\
\text { por } \\
\text { hectare) }\end{array}$ & $\begin{array}{c}\text { C } \\
\text { (em } \\
\text { Dólares de } \\
\text { Dezembro } \\
\text { de } 1992 \text { por } \\
\text { hectare) } \\
(7)\end{array}$ \\
\hline 1968 & 102.910 & 90.956 & & 12,51 & 100,00 & 19,17 & \\
\hline 1969 & 162.383 & 150.598 & 4,76 & 43,55 & 348,12 & 19,35 & $3.648,60$ \\
\hline 1970 & 222.005 & 203.522 & 4,79 & 83,20 & 665,07 & 19,54 & $3.749,36$ \\
\hline 1971 & 248.478 & 227.106 & 4,68 & 200,16 & $1.600,00$ & 20,20 & $3.869,15$ \\
\hline 1972 & 304.357 & 273.500 & 5,45 & 223,92 & $1.789,93$ & 20,81 & $4.336,23$ \\
\hline 1973 & 294.153 & 247.313 & 6,22 & 275,00 & $2.198,24$ & 21,19 & $5.008,08$ \\
\hline 1974 & 324.379 & 271.581 & 7,06 & 339,29 & $2.712,15$ & 21,58 & $5.581,34$ \\
\hline 1975 & 398.240 & 316.940 & 7,79 & 307,34 & $2.456,75$ & 22,02 & $5.738,44$ \\
\hline 1976 & 449.249 & 349.338 & 7,09 & 539,88 & $4.315,59$ & 23,82 & $5.306,82$ \\
\hline 1977 & 346.432 & 293.629 & 6,25 & 645,87 & $5.162,83$ & 25,56 & $5.079,68$ \\
\hline 1978 & 411.737 & 368.794 & 6,47 & 774,76 & $6.193,13$ & 26,26 & $5.267,56$ \\
\hline 1979 & 473.718 & 400.364 & 7,51 & 930,73 & $7.439,89$ & 27,62 & $5.144,03$ \\
\hline 1980 & 435.575 & 360.200 & 6,04 & 530,91 & $4.243,88$ & 28,97 & $5.146,38$ \\
\hline 1981 & 417.875 & 346.835 & 5,39 & 461,72 & $3.690,81$ & 29,42 & $5.224,56$ \\
\hline 1982 & 430.985 & 345.155 & 4,94 & 437,34 & $3.495,92$ & 29,44 & $5.248,45$ \\
\hline 1983 & 215.000 & 164.600 & 4,79 & 323,83 & $2.588,57$ & 30,53 & $4.780,31$ \\
\hline 1984 & 286.200 & 195.110 & 4,02 & 237,23 & $1.896,32$ & 32,47 & $4.929,36$ \\
\hline 1985 & 285.032 & 195.954 & 4,15 & 219,83 & $1.757,23$ & 33,87 & $5.503,55$ \\
\hline 1986 & 409.015 & 259.540 & 4,28 & 277,40 & $2.217,43$ & 35,08 & $5.764,12$ \\
\hline
\end{tabular}

FONTES: (1), (2), e (3) - BACHA (1993, p.137)

(4) e (5) - Dados fornecidos pelo BNB, confeccionados da seguinte maneira: até 1980, Centro de Informações Econômico-Fiscais (CIEF-MF); de 1981 em diante, BNB/DEMEC, de acordo com a Portaria do Ministério da Fazenda.

(6) - Veja Tabela 7

(7) - Veja Tabela 9 
Inicialmente, foi calculado um conjunto de regressões, considerando os valores totais da área reflorestada/florestada no Brasil (isto é, a área reflorestada/florestada com todas as espécies arbóreas) no período de 1970 a 1986, visto que os recursos oriundos dos incentivos fiscais ao reflorestamento/florestamento não eram destinados somente aos gêneros Pinus e Eucalyptus. Entretanto, diante da observação de que os valores obtidos para o preço médio recebido pela lenha oriunda da área reflorestada/florestada, para a produtividade da silvicultura brasileira e para os custos do reflorestamento/florestamento eram referentes aos gêneros Pinus e Eucalyptus (devido à sua grande importância no contexto da silvicultura brasileira, como já mencionamos anteriormente) resolvemos realizar regressões utilizando dados de área reflorestada/florestada somente com pinus e eucalipto (Aep), juntamente com um índice para os valores dos incentivos fiscais ao reflorestamento/florestamento. $\mathrm{O}$ uso do índice para incentivos fiscais ocorre por não serem disponíveis dados específicos sobre o volume destes incentivos destinados ao plantio de eucalipto e pinus ${ }^{22}$.

Os resultados desses dois conjuntos de regressões (o primeiro conjunto utilizando a área total reflorestada/florestada, $A t$, e o segundo conjunto utilizando a área reflorestada/florestada somente com pinus e com eucalipto, Aep) não foram satisfatórios ${ }^{23}$ (as variáveis $C_{t-1}$ e $A_{t-1}$ não apresentaram os sinais esperados e/ou apresentaram baixa significância estatística).

Estudando esses resultados, percebemos que o ano de 1986 foi atípico no que diz respeito aos investimentos realizados na silvicultura brasileira (devido ao Plano Cruzado, neste ano, houve um maior volume de investimentos em comparação aos anos anteriores). Assim, resolvemos incluir no nosso modelo uma variável dummy $\left(D_{t}\right)$ para tentar captar a atipicidade do ano de 1986.

Como na situação anterior, inicialmente, utilizamos dados da área total reflorestada/florestada em cada ano $\left(A_{t}\right)$ e, mais uma vez, não encontramos, para as regressões estimadas, os sinais esperados para as variáveis $C_{t-1}$ e $A_{t-1}$. Assim, passamos

${ }^{22}$ A pressuposição que adotamos é a de que o volume de incentivos fiscais destinados ao plantio dessas duas espécies exóticas teve a mesma evolução do montante total de incentivos fiscais destinados ao reflorestamento/florestamento.

${ }^{23}$ Por não serem satisfatórios, deixamos de apresentar os resultados dessas estimações. 
a utilizar apenas a área reflorestada/florestada em cada ano com o eucalipto e com o pinus (Aep). Entre as estimativas realizadas pelo Método do Mínimos Quadrados Ordinários (ver Apêndice D), a melhor foi:

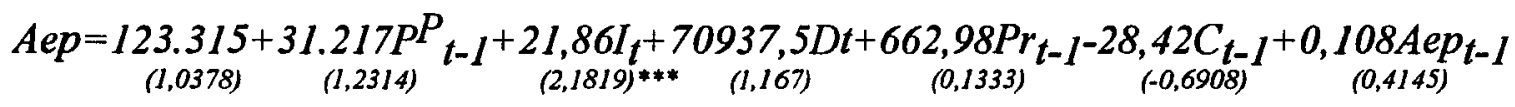

$$
\begin{aligned}
& R^{2}=0,748 \quad n=17 \quad F=5,89 * *
\end{aligned}
$$

Onde: os valores entre parênteses sob os coeficientes estimados referem-se à estatística $t:{ }^{* *}$ indica o coeficiente ser estatisticamente significativo a $1 \% \mathrm{e}^{* * *}$ indica $\mathrm{o}$ coeficiente ser estatisticamente significativo a $5 \%$.

O valor do teste " $F$ " apresenta alta significância estatística, o que nos permite rejeitar, a $1 \%$ de nível de significância, a hipótese de que os coeficientes sejam iguais a zero.

O coeficiente de determinação $\left(R^{2}\right)$ mostra um valor satisfatório, ou seja, 74,8\% da variância da área reflorestada/florestada pode ser explicada pelas variáveis presentes no modelo.

Os coeficientes das variáveis desta equação apresentam os sinais esperados mas, com exceção da variável Incentivos Fiscais do Governo ao Reflorestamento/Florestamento, apresentam, juntamente com o termo constante, baixa significância estatística. Esses valores baixos da estatística t ocorreram porque utilizamos dados nacionais para estimar nossa regressão, o que implica numa grande variância nas observações. Infelizmente, não há dados regionalizados da variável $I_{t}$ para estimarmos a equação (7), no período de 1970 a 1986, a níveis de Estados e/ou segmentos reflorestadores/florestadores. Se isto fosse possível, esperaríamos obter melhores valores para a estatística t.

Observando o Apêndice $\mathrm{D}$, constatamos que em várias regressões realizadas o sinal da variável $C_{t-1}$ foi inverso ao esperado. Isto ocorreu pelo fato de no período de 1970 a 1986 ter havido grande aumento da demanda por produtos florestais que, diante 
de um aumento menos que proporcional na oferta dos mesmos, provocava um aumento dos preços. Além disso, ocorriam generosas concessões de incentivos físcais pelo governo ao reflorestamento/florestamento. Diante deste cenário, pouca importância era dada aos custos de produção. Os aumentos reais dos preços dos insumos e dos fatores de produção (que provocavam aumentos nos custos de produção) não eram considerados ou eram avaliados como secundários face às inúmeras vantagens para aumentar-se a área reflorestada/florestada. Em última análise, podemos dizer que os efeitos provocados por estes aumentos dos preços dos insumos e dos fatores de produção eram "mascarados" pela existência destas outras vantagens.

Dessa forma, os custos do reflorestamento/florestamento influenciaram pouco a variação ocorrida na área reflorestada/florestada neste periodo de tempo referenciado. Isto trouxe algumas conseqüências importantes, como, por exemplo, um grande desperdício de recursos, bem como uma baixa eficiência dos projetos implantados.

CALLAHAN (1979) reforça este nosso argumento com sua análise sobre o período de vigência, no Brasil, do Programa de Incentivos Fiscais ao Reflorestamento/Florestamento. Este autor menciona que o citado período foi marcado pela ineficiência econômica (altos custos de implantação das florestas, gastos de recursos financeiros em práticas administrativas e de manejo ineficientes, plantio de árvores em terras de agricultura e fornecimento indireto de subsídios à remoção de árvores) e pela desigual distribuição de recursos.

BERGER (1979) disse que há vários trabalhos que chamam atenção para os altos custos do reflorestamento/florestamento ocorridos durante a vigência dos incentivos fiscais ao reflorestamento/florestamento e que acabaram sendo financiados pelo governo.

Assim, podemos dizer que mesmo num cenário de desenvolvimento tecnológico acentuado (devido, principalmente, ao desenvolvimento das pesquisas), à medida que questões importantes não eram consideradas - como levantamentos de custos e a escolha do sistema de produção mais adequado - contribuía-se para a baixa eficiência dos projetos de reflorestamento/florestamento.

Se o nosso modelo original fosse utilizado com dados dos últimos anos, por exemplo - período no qual já não houve o oferecimento de incentivos fiscais pelo 
Governo Federal ao reflorestamento/florestamento - certamente, em decorrência da tendência verificada de uma procura por eficiência, a variável custo do reflorestamento/florestamento teria uma participação mais importante na determinação da área reflorestada/florestada e, conseqüentemente, na expansão da silvicultura brasileira como um todo.

Como não há dados disponíveis para a área reflorestada/florestada para todo o Brasil após o ano de 1986, para testarmos esta nossa suposição, consideramos o reflorestamento/florestamento realizado pelas empresas de papel e celulose. Esta escolha foi devida, principalmente, à importância destas empresas no contexto da silvicultura brasileira e à disponibilidade e especificidade dos dados.

Assim, utilizamos dados do acréscimo de área reflorestada/florestada com eucalipto e pinus pelas empresas de papel e celulose; dados do preço médio do estéreo de madeira destinada à fabricação de celulose; um índice de evolução dos incentivos fiscais ${ }^{24}$; dados da produtividade média da silvicultura brasileira e dados de custos do reflorestamento/florestamento levantados para o Estado de São Paulo (Tabela 11).

${ }^{24}$ Supusemos que o comportamento do volume de incentivos fiscais concedidos às empresas de papel e celulose foi o mesmo que o comportamento do volume nacional de incentivos fiscais destinados ao reflorestamento/florestamento. 
TABELA 11 - ACRÉSCIMO DE ÁREA REFLORESTADA/FLORESTADA COM PINUS E EUCALIPTO PELAS EMPRESAS DE PAPEL E CELULOSE (AEP); PREÇO MÉDIO DO ESTÉREO DE MADEIRA DESTINADA À FABRICAÇÃO DE CELULOSE (P); ÍNDICE DE EVOLUÇÃO DOS INCENTIVOS FISCAIS (I); PRODUTIVIDADE MÉDIA DA SILVICULTURA BRASILEIRA (PR) E CUSTOS DO REFLORESTAMENTO/FLORESTAMENTO LEVANTADOS PARA O ESTADO DE SÃO PAULO (C).

\begin{tabular}{|c|c|c|c|c|c|}
\hline Ano & $\begin{array}{c}\text { Aep } \\
\text { (hectares) } \\
\text { (A) }\end{array}$ & $\begin{array}{c}\text { P (dólares de } \\
\text { dezembro de } \\
\text { 1992) } \\
\text { (B) }\end{array}$ & $\begin{array}{c}\text { I } \\
(1968=\text { base100) } \\
\text { (C) }\end{array}$ & $\begin{array}{c}\mathbf{P r} \\
\text { (estéreos/hectare) } \\
\text { (D) }\end{array}$ & $\begin{array}{c}\text { C (dólares de } \\
\text { dezembro de } \\
\text { 1992) } \\
\text { (E) }\end{array}$ \\
\hline 1980 & & & & 28,97 & \\
\hline 1981 & & 0,0130 & & 29,42 & $6.327,83$ \\
\hline 1982 & $77.503,0$ & 0,0118 & $3.495,92$ & 29,44 & $6.349,35$ \\
\hline 1983 & $65.403,0$ & 0,0118 & $2.588,57$ & 30,53 & $5.465,18$ \\
\hline 1984 & $77.295,0$ & 0,0118 & $1.896,32$ & 32,47 & $5.849,03$ \\
\hline 1985 & $83.282,0$ & 0,0123 & $1.757,23$ & 33,87 & $6.705,41$ \\
\hline 1986 & $81.597,0$ & 0,0129 & $2.217,43$ & 35,08 & $6.127,93$ \\
\hline 1987 & $88.370,0$ & 0,0133 & $1.287,29$ & 36,27 & $5.666,54$ \\
\hline 1988 & $102.054,0$ & 0,0139 & 164,11 & 37,98 & $6.434,44$ \\
\hline 1989 & $118.050,0$ & 0,0402 & 0,00 & 39,62 & $5.744,05$ \\
\hline 1990 & $122.562,0$ & 0,0098 & 0,00 & 40,98 & $6.682,51$ \\
\hline 1991 & $82.253,4$ & 0,0096 & 0,00 & 43,99 & $4.039,16$ \\
\hline 1992 & $84.756,9$ & 0,0091 & 0,00 & 41,36 & $4.215,34$ \\
\hline 1993 & $89.424,5$ & & 0,00 & 41,07 & \\
\hline
\end{tabular}

FONTES: (A) e (B)- ANFPC (1982 a 1993)

(C) - Dados fornecidos pelo BNB, confeccionados da seguinte maneira: até 1980, Centro de Informações Econômico-Fiscais (CIEF-MF); de 1981 em diante, BNB/DEMEC, de acordo com a Portaria do Ministério da Fazenda.

(D) - Apêndice B

(E) - Apêndice C

Entre as estimativas realizadas pelo Método dos Mínimos Quadrados, a melhor foi:

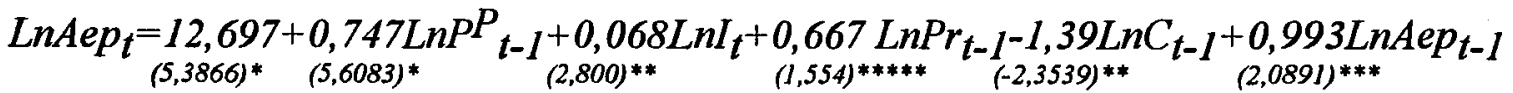

$$
\begin{aligned}
& R^{2}=0,9517 \quad n=12 \quad F=23,658^{*}
\end{aligned}
$$


Onde: os valores entre parênteses sob os coeficientes estimados referem-se à estatística $\mathrm{t}:{ }^{*}$ indica o coeficiente ser estatisticamente significativo a $0,05 \%, * *$ indica $o$ coeficiente ser estatisticamente significativo a $1 \%, * * *$ indica 0 coeficiente ser estatisticamente significativo a $5 \%$ e $* * * * *$ indica o coeficiente ser estatisticamente significativo a $20 \%$.

$O$ valor do teste " $F$ " apresenta alta significância estatística, o que nos permite rejeitar, a 0,05\% de nível de significância, a hipótese de que os coeficientes sejam iguais a zero. $O$ coeficiente de determinação $\left(\mathrm{R}^{2}\right)$ mostra um valor satisfatório, ou seja, 95,8\% da variância da área reflorestada/florestada pode ser explicada pelas variáveis presentes no modelo. Os coeficientes das variáveis desta equação apresentam os sinais esperados e, juntamente com o termo constante, apresentam boa significância estatística.

$O$ teste t para testar se o coeficiente da variável $A e p_{t-I}$ é estatisticamente diferente de um apresentou baixa significância estatística, não nos deixando rejeitar tal hipótese. Assim, não há, para as empresas de papel e celulose, defasagem no processo de ajustamento da área observada à área desejada.

Através desta equação (que está medida em logaritmos neperianos dos valores originais, sendo, portanto, os coeficientes dessas variáveis as elasticidades de $A_{e} p_{t}$ em relação a cada variável), constatamos que o valor absoluto da elasticidade de $A e p_{t}$ em relação $C_{t-1}$ é maior que os outros valores absolutos das elasticidades de Aept em relação às demais variáveis. $\mathrm{O}$ valor absoluto da elasticidade $A e p_{t}$ em relação a $P p_{t-1}$ é maior que o valor absoluto da elasticidade de $A e p_{t}$ em relação a $\operatorname{Pr}_{t-l}$ e este último valor é maior que o valor absoluto da elasticidade de $A e p_{t}$ em relação a $I_{t}$.

Em suma, pudemos confirmar nossa suposição de que a importância atribuída aos custos do reflorestamento/florestamento na determinação da área reflorestada/florestada foi sensivelmente elevada nos últimos anos, principalmente devido ao fim do oferecimento dos incentivos fiscais por parte do governo.

Através da equação estimada acima, também pudemos confirmar a importância das inovações tecnológicas - à medida que provocam aumentos de produtividade - para a expansão da área reflorestada/florestada ocorrida nas empresas de papel e celulose. 


\section{CAPÍTULO 4 - CONCLUSÕES}

A partir da década de sessenta, houve uma grande expansão da área reflorestada/florestada no Brasil. Esta expansão da silvicultura brasileira pode ser associada, entre outros, a um processo de evolução tecnológica que verificamos ter ocorrido nesta atividade.

Devido a isto, o objetivo deste trabalho foi fazer uma análise das inovações tecnológicas ocorridas na silvicultura brasileira, bem como estudar os seus impactos sobre a expansão desta atividade. Para isto, concentramos nossa atenção nos gêneros Eucalyptus e Pinus, cujas espécies são as mais plantadas no Brasil.

Em termos globais, houve três fases na evolução da silvicultura, no Brasil: a primeira fase foi do descobrimento do Brasil até o início dos incentivos físcais ao reflorestamento/florestamento (em 1965); a segunda fase abrangeu o período de vigência dos incentivos fiscais ao reflorestamento/florestamento (1965 a 1988); e a terceira fase refere-se ao período pós-incentivos fiscais ao reflorestamento/florestamento (de 1989 até os dias de hoje).

A exemplo do que existe para o setor industrial, as inovações tecnológicas que ocorreram na silvicultura podem ser estudadas de acordo com conceitos próprios. Assim, podemos classificar as inovações tecnológicas ocorridas na silvicultura brasileira como sendo: mecânicas, biológicas, químicas, agronômicas ou gerenciais; de produto ou de processo; grandes ou pequenas inovações; e importadas ou nacionais.

De forma geral, comparando os sistemas de produção passados e atuais, tanto para o eucalipto quanto para o pinus, percebemos que houve grandes transformações nas últimas quatro décadas. Atualmente, busca-se um controle eficaz das operações, procurase a qualidade total, há desenvolvimento nas áreas de coleta e análise de dados, há um grande horizonte de planejamento prévio, etc. - aspectos estes que não eram verificados nos sistemas de produção passados. 
Quanto à pesquisa na silvicultura brasileira (sobre pinus e eucalipto), podemos dizer que em toda primeira metade do atual século, houve pouco em termos de novas propostas. Um maior desenvolvimento da pesquisa teve início na década de cinqüenta com trabalhos concentrados na área de manejo, sendo que este cenário perdurou até o final da década de sessenta. A partir de então, uma preocupação com o melhoramento genético passou a dominar os trabalhos de pesquisa (houve, principalmente, trabalhos relacionados a testes de espécies e testes de procedências). A partir do final da década de setenta, quando já havia uma população geneticamente superior no Brasil, três áreas de pesquisa apresentaram um desenvolvimento conjunto e destacado: a área de adubação, a área de produção de mudas e novamente a área de melhoramento genético (agora, em trabalhos relacionados a testes de progênies, principalmente). A partir do final da década de oitenta, houve uma distribuição dos trabalhos sobre todas as áreas de pesquisa (manejo, melhoramento genético, produção de mudas, controle de pragas e doenças, adubação, mecanização e gerencial). Teve início, também a partir deste período, uma tendência (que era inevitável mas que foi acelerada pelo fim dos incentivos fiscais ao reflorestamento/florestamento) que ainda hoje ocorre: a da procura, através das pesquisas, de técnicas que proporcionem eficiência (isto é, redução nos custos, maior produtividade, maior qualidade e maior competitividade). Nesta tendência, veio inserida uma maior preocupação com questões ecológicas. Assim, os estudos voltaram-se um pouco mais para as espécies nativas, que, contrariamente ao grande desenvolvimento da pesquisa sobre pinus e eucalipto verificado na silvicultura brasileira nestes últimos trinta anos, foram pouco enfocadas neste período.

Considerando que os trabalhos de pesquisa geram propostas de técnicas que somente poderão ser denominadas de inovações tecnológicas se forem realmente incorporadas aos sistemas de produção, podemos dizer (ressaltando as dificuldades para se analisar a adoção efetiva de novas tecnologias) que, apesar de uma certa diferença no tempo em que ocorrem, os processos de desenvolvimento da pesquisa e da evolução tecnológica ocorridos na silvicultura brasileira passaram pelas mesmas etapas básicas. As pesquisas na área de melhoramento genético ocorridas no início da década de setenta, por exemplo, somente resultaram em inovações tecnológicas (que podem ser classificadas 
como biológicas, de processo e/ou de produto, grandes inovações e nacionais) importantes a partir da segunda metade da década de setenta.

A relação entre inovação tecnológica e expansão da sivicultura brasileira pode ser estabelecida através da produtividade. Em geral, podemos dizer que a evolução tecnológica ocorrida na silvicultura brasileira provocou um aumento geral da produtividade que, por sua vez, reduziu os custos do reflorestamento/florestamento. Esta redução elevou a rentabilidade da silvicultura, causando a sua expansão. Isto foi comprovado pela nossa equação da área reflorestada/florestada, que mostra a importância das inovações tecnológicas - ao lado do preço da madeira oriunda de matas plantadas e dos incentivos fiscais do Governo Federal ao reflorestamento/florestamento para a expansão da área reflorestada/florestada ocorrida no Brasil.

O fato de termos utilizado dados agregados a nível de Brasil para o período de 1970 a 1986 não nos permitiu obter, nas estimativas feitas para a expansão da área reflorestada/florestada, bons níveis de significância. Além disso, no período abrangido pelo nosso estudo (1970 a 1986), ocorreram, simultaneamente, alguns processos importantes que apresentavam uma forte influência sobre a área reflorestada/florestada brasileira, influência esta que acabava sobrepondo-se sobre as demais. Estes processos, definidos na nossa equação, consistiam, principalmente, no aumento da demanda por produtos florestais que, diante de um aumento menos que proporcional na oferta dos mesmos, provocava um aumento dos preços; no oferecimento de incentivos fiscais pelo governo ao reflorestamento/florestamento e no acelerado desenvolvimento tecnológico. Diante deste cenário, pouca importância era dada aos custos de produção. Os aumentos reais dos preços dos insumos e dos fatores de produção (que provocavam aumentos nos custos de produção) não eram considerados ou eram avaliados como secundários face às inúmeras vantagens para aumentar-se a área reflorestada/florestada. Em última análise, podemos dizer que os efeitos provocados por estes aumentos dos preços dos insumos e dos fatores de produção eram "mascarados" pela existência destas outras vantagens. Dessa forma, os custos do reflorestamento/florestamento influenciaram pouco a variação ocorrida na área reflorestada/florestada no período de 1970 a 1986. Isto trouxe algumas 
conseqüências importantes, como, por exemplo, um grande desperdício de recursos e má aplicação das inovações tecnológicas nos sistemas de produção.

Quando nosso modelo original foi estimado com dados das empresas de papel e celulose para o período de 1982 a 1993, melhores resultados estatísticos foram obtidos e a variável custo do reflorestamento/florestamento teve uma participação mais importante na determinação da área reflorestada/florestada. Isto porque nesse período de 1982 a 1993, ocorreu a interrupção de concessões de Incentivos Fiscais ao reflorestamento/florestamento, levando as empresas a se preocuparem com os custos de implantação e condução dos reflorestamentos/florestamentos. Também nas equações estimadas para o reflorestamento/florestamento feito pelas empresas de papel e celulose, a produtividade exerceu forte impacto sobre a expansão da área reflorestada/florestada. 


\section{REFERÊNCIAS BIBLIOGRÁFICAS}

ABRACAVE (1994), Associação Brasileira de Carvão Vegetal, Anuário Estatístico Anual, Belo Horizonte MG, 1994

AFONSO NETO, M.J. (1986) "Uma atividade estratégica" in Informe Agropecuário (141): 1, Belo Horizonte, Setembro de 1986, Ano 12.

AHRENS, S. (1987) "A Concepção de Regimes de Manejo para Plantações de Pinus spp no Brasil" Circular Técnica número 10, EMBRAPA, Curitiba, Paraná, Julho, 1987.

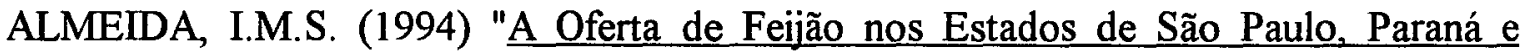
Minas Gerais" Dissertação de Mestrado, Departamento de Economia e Sociologia Rural, ESALQ/USP, Piracicaba, 1994, 136 páginas.

ANFPC - Associacão Nacional dos Fabricantes Papel e Celulose (1991), Relatório Estatístico Anual, São Paulo, 1991.

ANFPC - Associacão Nacional dos Fabricantes Papel e Celulose (1992), Relatório Estatístico Anual, São Paulo, 1992.

ANFPC - Associacão Nacional dos Fabricantes Papel e Celulose (1993), Relatório Estatístico Anual, São Paulo, 1993. 
ANFPC - Associacão Nacional dos Fabricantes Papel e Celulose (1994), Relatório Estatístico Anual, São Paulo, 1994.

ANUÁRIO ESTATÍSTICO DO BRASIL (1975), Secretaria de Planejamento da Presidência da República, Fundação Instituto Brasileiro de Geografia e Estatística, Rio de Janeiro, volume 36, 1975, 1016 páginas.

ANUÁRIO ESTATÍSTICO DO BRASIL (1977), Secretaria de Planejamento da Presidência da República, Fundação Instituto Brasileiro de Geografia e Estatística, Rio de Janeiro, volume 38, 1977, 848 páginas.

ANUÁRIO ESTATÍSTICO DO BRASIL (1980), Secretaria de Planejamento da Presidência da República, Fundação Instituto Brasileiro de Geografia e Estatística, Rio de Janeiro, volume 41, 1980, 840 páginas.

ANUÁRIO ESTATÍSTICO DO BRASIL (1985), Secretaria de Planejamento da Presidência da República, Fundação Instituto Brasileiro de Geografia e Estatística, Rio de Janeiro, volume 46, 1985, 760 páginas.

ANUÁRIO ESTATÍSTICO DO BRASIL (1987/88), Secretaria de Planejamento da Presidência da República, Fundação Instituto Brasileiro de Geografia e Estatística, Rio de Janeiro, volume 48, 1987/88, 740 páginas.

ARAÚJO, J.D. (1989) "Padrões Tecnológicos e Transformações no Setor Leiteiro - Uma Abordagem Schumpeteriana", Tese de Doutorado, Faculdade de Economia e Adminstração, Departamento de Economia, USP, São Paulo, 1989.

ASSOCIAÇÃO BRASILEIRA DE AGRIBUSINESS (1993) Segurança Alimentar Uma Abordagem de Agribusiness. São Paulo,1993. 162 páginas. 
BACHA, C.J.C. (1992 a) "A situação atual dos dados sobre o reflorestamento no Brasil" in Revista Análise Econômica, 10 (17): 145-155, Porto Alegre, Março de 1992.

BACHA, C.J.C. (1992 b) "Alguns Aspectos dos Modelos de Análise dos Impactos de Mudança Tecnológica no Comportamento do Setor Agrícola" in Revista de Economia e Sociologia Rural, v. 30, n. 1, p. 41-62, janeiro/março, Brasília, 1992.

BACHA, C.J.C. (1993) "A Dinâmica do Desmatamento e do Reflorestamento no Brasil", Tese de Livre Docência, ESALQ/USP, Piracicaba, 1993.

BACHA, C.J.C. (1995) "Análise custo-beneficio dos programas federais de incentivos ao reflorestamento no Brasil", Relatório de Pesquisa CNPq, Piracicaba, março de 1995, 93 páginas.

BARROS, G.S.C. (1987) Economia da Comercialização Agrícola, Piracicaba, FEALQ, 1987, 306 páginas.

BEATTIE, W.D. \& FERREIRA, J.M. (1978) Diagnóstico do subsetor florestal do Brasil - Análise Financeira e Sócio-Econômica do Reflorestamento no Brasil, COPLAN/IBDF, Ministério da Agricultura, Brasília, 1978.

BERGER, R. (1979) "The Brazilian Fiscal Incentive Act's Influence on Reforestation Activity in São Paulo State", Dissertation, Phylosophy Doctor, Department of Forestry, Michigan State University, USA, 1979.

BOLETIM № 5 (1961) "Altura de Pinus sp" in Boletim número 5 do Serviço Florestal do Estado de São Paulo, Secretaria da Agricultura, São Paulo, p. 9, 1961. 
BRANCO, E.F.(1994) Plantio de Eucalipto, Instituto de Pesquisas e Estudos Florestais, Piracicaba, SP, Outubro, 1994.

BREPOHL, D. (1980) "Custos em Empreendimentos Florestais", Série Técnica número 4, FUPEF, Curitiba, Novembro, 1980.

CALLAHAN, J.C. "Forestry Fiscal Incentive: The Brazilian Experience" West Lafayette, Ind: Department of Forestry and Natural Resources, Purdue University, EUA, 1979.

CARDONA, M. (1992), in Revista Silvicultura, no 45, Ano 12, São Paulo, Setembro Outubro, 1992.

CIANCIULLI, P.L. (1954) Introdução de Essências Florestais. Secretaria da Agricultura, Serviço Florestal, São Paulo, 1954, 30 páginas.

DE JANVRY, A. (1973) A Socioeconomic Model of Induced Innovations for Argentine Agricultural development. in Quartely Journal of Economics, n. 3, p. 410435, Ago, 1973.

EMBRAPA (1983/1984) Empresa Brasileira de Pesquisa Agropecuária, Relatório de Atividades, São Paulo, 14 páginas, 1983/1984.

ENCONTRO NACIONAL DE REFLORESTADORES (1977), 3., Abril de 1977, São Paulo, SP, p. 6-10, 1977.

ENCONTRO NACIONAL DE REFLORESTADORES (1978), 4., 12 de Maio de 1978, Campo Grande, MS, p. 113, 1978. 
FERREIRA, C. A. (1993) "Nutrição Mineral das Florestas Plantadas: o Estado Atual e Tendência da Pesquisa e da Prática." In: Congresso Florestal Panamericano/Congresso Florestal Brasileiro, 1./7., p.157, Curitiba, Paraná, 19 a 24 de Setembro, 1993.

FLANZEN, H. (1979) "Painel de Reflorestamento e Ecologia" in Jornal dos Reflorestadores, São Paulo, 1(2): 33-4, 1979.

GARLIPP, R.C.D. (1982) "Biomassa das Florestas Plantadas como Fonte Alternativa de Energia em Substituição ao Óleo Combustível Industrial no Estado de São Paulo", Tese de Mestrado, Departamento de Ciências Florestais, ESALQ/USP, Piracicaba, 1982, 175 páginas.

GOLFARI, L. (1978) Zoneamento Ecológico Esquemático para o Reflorestamento no Brasil: Segunda Aproximação, Série Técnica. PRODEPEF, Brasilia, (11):1$67,1978$.

GOMES, J.M. \& COUTO, L. (1986) "Produção de Mudas de Eucalipto" in Revista Informe Agropecuário no 141, Ano 12, Belo Horizonte, MG, Setembro, 1986.

GURGEL FILHO, O.A. (1962) O Reflorestamento, Secretaria da Agricultura, Serviço Florestal, Boletim no 6, São Paulo, p.25, 1962.

HAYAME, Y. \& RUTTAN,V. (1988) Desenvolvimento Agrícola - Teoria e Experiências Internacionais, Departamento de Publicação,Brasília, D.F., 1988, 583 páginas.

HOFFMANN, R. \& VIEIRA, S. (1987) Análise de Regressão - Uma Introducão à Econometria, São Paulo, Hucitec, 1987, 379 páginas. 
HOSSAIN, S.M.A. \& CROUCH, B.R. (1992) "Patterns and determinants of adoption of farm practices: some evidence from Bangladesh" Department of Agriculture, University of Queensland, St Lucia, Queensland, Australia, 1992, p.1-15.

HOSOKAWA, R.T. (1987) "Funções e Tarefas das Florestas" in Anais do Simpósio sobre Silvicultura y Mejoramento Genético de Espécies Forestales, Buenos Aires, 1987. p. 112-122.

IBGE (1984) - METODOLOGIA DO CENSO AGROPECUÁRIO DE 1980 Série Relatórios Metodológicos - IBGE. 1984. p.66.

INFORMAÇÕES ESTATÍSTICAS DA AGRICULTURA (1992), Revista Informações Estatísticas da Agricultura, Estatística de Mercado de Terras Agrícolas no Estado de São Paulo, Instituto de Economia Agrícola, Série IEA, volume 4, número 2, São Paulo, 1992.

INFORMAÇÕES ECONÔMICAS (1990), Revista Informações Econômicas, Instituto de Economia Agrícola, volume 20, número 12, 1990.

INFORMAÇÕES ECONÔMICAS (1991), Revista Informações Econômicas, Instituto de Economia Agrícola, volume 21, número 12, 1991.

INFORMAÇÕES ECONÔMICAS (1992), Revista Informações Econômicas, Instituto de Economia Agrícola, volume 22, número 12, 1992.

INFORMAÇÕES ECONÔMICAS (1993), Revista Informações Econômicas, Instituto de Economia Agrícola, volume 23, número 12, 1993. 
INFORMAÇÕES ECONÔMICAS (1994), Revista Informações Econômicas, Instituto de Economia Agrícola, volume 24, número 12, 1994.

INFORMAÇÕES ECONÔMICAS (1995), Revista Informações Econômicas, Instituto de Economia Agrícola, volume 25, número 12, 1995.

INFORME AGROPECUÁRIO (1986), Revista Informe Agropecuário, Ano 12, No 141, Belo Horizonte, MG, Setembro, 1986 (número especial sobre a eucalpitocultura).

IPEF - Circular Técnica número 14 (1977) "Aspectos Econômicos da Fertilização Fosfatada em Eucalipto, 1977, 6 páginas.

JOLY, A.B. (1975) Botânica - Introdução à taxonomia vegetal, Editora da Universidade de São Paulo, São Paulo, 1975, 777 páginas.

LEITE, N.B.(1979) "Beneficios Diretos e Indiretos da Atividade Florestal" in Jornal dos Reflorestadores. São Paulo, 1 (2): 12-3, 1979.

MAGALHÃES, J.G.R. (1986) "Produção de Sementes de Eucalipto" in Revista Informe Agropecuário, no 141, Ano 12, Belo Horizonte, MG, 1986.

NAVARRO DE ANDRADE, E. (1961) O Eucalipto, Segunda Edição, Jundiaí, Companhia Paulista de Estradas de Ferro, 1961, 665 páginas.

NIEBUHR, H.G.; ZYL, J. e VAN,Z.J. (1990) "An econometris analysis of the supply of wheat in South Africa: a regional approach" Department Landbou-ekenomie, University van Pretoria, Pretoria,1990, p. 324-334.

PASTORE, A.C. (1973) A Resposta da Produção Agrícola aos Preços no Brasil, São Paulo, APEC, 1973, 170 páginas. 
PEREIRA, B.A.S. (1990) Introdução de Coníferas no Brasil - Um Esboço Histórico, Caderno de Geociências no 4, IBGE/DF, p.25-38, Rio de Janeiro, 1990.

PEREIRA, J.J (1991) "Caracterização Tecnológica de Pequenas e Grandes Empresas Florestais do Estado de Minas Gerais" Dissertação de Mestrado, Universidade Federal de Viçosa, Viçosa, 1991.

PRATES, F.B. (1979) "O Aproveitamento da Madeira dos Provoamentos de Pinus" in Jornal dos Reflorestadores. São Paulo, volume 1, número 2, 1979.

PREÇOS PAGOS PELOS AGRICULTORES (1970/1974), Fundação Getúlio Vargas, Instituto Brasileiro de Economia, Divisão de Estatística e Economia, Centro de Estudos Agrícolas, São Paulo, 1970/1974.

PREÇOS PAGOS PELOS AGRICULTORES (1974/1979), Fundação Getúlio Vargas, Instituto Brasileiro de Economia, Divisão de Estatística e Economia, Centro de Estudos Agrícolas, São Paulo, 1974/1979.

PREÇOS PAGOS PELOS AGRICULTORES (1980/1981), Fundação Getúlio Vargas, Instituto Brasileiro de Economia, Divisão de Estatística e Economia, Centro de Estudos Agrícolas, São Paulo, 1980/1981.

PREÇOS PAGOS PELOS AGRICULTORES (1982/1983), Fundação Getúlio Vargas, Instituto Brasileiro de Economia, Divisão de Estatística e Economia, Centro de Estudos Agrícolas, São Paulo, 1982/1983.

PREÇOS PAGOS PELOS AGRICULTORES (1984/1985), Fundação Getúlio Vargas, Instituto Brasileiro de Economia, Divisão de Estatística e Economia, Centro de Estudos Agrícolas, São Paulo, 1984/1985. 
RATTNER, H.; JONHSON, B.B.; LIMA, L.E. e SILBER, S.D. (1993) "A produtividade e competitividade do setor de Papel e Celulose Brasileiro" FIPE/FINEP, São Paulo, 1993.

SARKAR, A,U. \& McKILLOP, W.P. (1993) "Modelling timber supply: resources and management regimes", Journal of Environmental Management, State University of New York, Fredonia, New York, 1993. p.1-11.

SCHULZE, P,C.; LEIGHTON, M. \& PEART, D.R. "Enrichment planting in selectively logged rain forest: a combined ecological and economic analisys" Department of Earth and Environmental Science, Lehigh University, Bethlehem, Pennsylvania, USA, 1994, p. 581-582.

SHEBOURNE, J.; HALBRENDT, C. e GEMPESAW, C.M. (1991) "The impact of government policy upon productivity changes: the case of farms in the Amazon region of Brazil", Department of Food \& Resource Economics, University of Delaware, Newark, Delaware, USA, 1991, p. 207-221.

SILVA, C.R.L. (1992) "Inovação Tecnológica na Agricultura Brasileira - Aspectos Distributivos". Tese de Doutorado; Departamento de Economia. Faculdade de Economia, Administração e Contabilidade - USP, São Paulo, 1992, 216 páginas.

SILVA, G.L.S.P. (1982) "Evolução e Determinantes da Produtividade Agrícola: O Caso da Pesquisa e da Extensão Rural em São Paulo". Tese de Doutorado; Departamento de Economia; Faculdade de Economia, Administração e Contabilidade - USP, São Paulo, 1982, 230 páginas. 
SILVICULTURA (1977) "Equipamentos Florestais no Brasil: eles existem?" in Revista Silvicultura, no 6, Ano I, Maio - Junho, 1977.

SIMPÓSIO MANEJO DE FLORESTAS PLANTADAS (1991) Esteio, RS, 26 e 27 de Setembro, 1991, 238 páginas.

SIQUEIRA, J.D.P. (1990) "A Atividade Floresta como um dos Instrumentos de Desenvolvimento do Brasil" in Congresso Florestal Brasileiro, 6., p.15-18, Campos do Jordão-SP, 1990.

TOLEDO, P.E.N. ; YAMAZOE, G. e MORAES, J.L. (1987) Análise de Investimento em Sistemas Alternativos de Produção de Eucalipto em uma Propriedade Agrícola Relatório de Pesquisa, IEA, número 07/87, IEA/SAA, São Paulo, 1987.

TOLEDO, Y.I.M. (1994) Comportamento do Emprego na Silvicultura Paulista. Tese de Doutorado, UNICAMP, Campinas SP, 1994.

TUAZON, R.N. (1993) "A econometric analysis of nonindustrial timber supply: implications of demographic change", Ph.D. Thesis, University of Califfornia, Berkeley, USA, 1993, 105 páginas.

VICTOR, M.A.M. et alii (1972) Evolução, estágio atual e perspectivas das florestas exóticas em São Paulo, Boletim Técnico - Instituto Florestal, São Paulo, (1) : $1-32,1972$.

VICTOR, M.A.M. (1977) "O Reflorestamento Incentivado, 10 Anos Depois" in Revista Silvicultura, número 6, Ano I, Maio - Junho, 1977. 
WANG, D. (1994) "Renewability, and optimal waiting: toward a general theory of resouce economics", School of Economics and Finance, University of Hong Kong, number 150, 1994, 18pp..

YAO, S.J. (1994) "Agricultural reforms and grain production in China" Department of Economics, University of Portsmouth, Portsmouth, UK, 1994, p.7.. 


\section{APÊNDICE A - Lista de Trabalhos Científicos sobre a Silvicultura no Brasil}

A seguir, apresentamos as referências bibliográficas dos trabalhos científicos sobre a silvicultura brasileira que foram publicados na revistas FLORESTA (no período de 1969 a 1992), IPEF (no período de 1970 a 1994) e ÁRVORE (no período de 1977 a 1994) e nos Anais do I, II, III, IV, V, VI e VII Congressos Florestais Brasileiros, realizados nos anos de 1953, 1973, 1978, 1983, 1986, 1990 e 1993, respectivamente.

Os trabalhos estão citados cronologicamente segundo cada segmento de área de pesquisa, havendo casos de um mesmo trabalho abranger mais do que um segmento de pesquisa.

\section{1) Melhoramento Genético}

1.1) Teste de Procedências

1971: 1 trabalho

BALDANZI, G. e ARAÚJO, A.J. Ensaio comparativo de espécie e procedências de Pinus, na Estação de Pesquisas Florestais de Rio Negro, Paraná. In FLORESTA, Curitiba, $\underline{3}(2)$ : 86-89, Novembro 1971.

1973: 2 trabalhos

BALDANZI, G.; RITTERSHOFER, F.O. e REISSMANN, C.B. (1973a) "Ensaios de Procedência de Pinus taeda na estação de Pesquisas Florestais de Rio Negro." In: Congresso Florestal Brasileiro, 2., p. 124, Curitiba, Paraná, 17 a 21 Set., 1973.

BALDANZI, G.; RITTERSHOFER, F.O. e REISSMANN, C.B. (1973b) "Procedências de Pinus sp adaptadas às Condições Ecológicas dos Planaltos Sulinos." In: Congresso Florestal Brasileiro, 2., p. 125, Curitiba, Paraná, 17 a 21 Set., 1973.

1974: 2 trabalhos

BALDANZI, G.; RITTERSCHOFER, F.O. e REISSMANN, C.B. Procedências de Pinus spp adaptados às condições ecológicas dos planaltos sulinos. FLORESTA, Curitiba, $\underline{5}(1)$ : 31-34, 1974.

PÁSZTOR, Y.P.C. Teste de Procedência de E. pilularis Sm na região de Mogi Guaçu. $\underline{\text { IPEF}}$ Piracicaba, (8): 69-93, Outubro 1974.

1976: 1 trabalho

BALDANZI, G. e MALINOVSKI, J.R. Ensaio comparativo de diferentes origens de $P$. taeda e $P$. elliottii. FLORESTA, Curitiba, 7(1): 5-8, 1976. 
1977: 3 trabalhos

BARRICHELO, L.E.G.; KAGEYAMA, P.Y.; SPELTZ, R.M.; BONISH, H.J. e BRITO, J.O. Estudo de procedência de Pinus taeda, visando seu aproveitamento industrial. IPEF, Piracicaba, (15): 1-14, Dezembro 1977.

GOMES, J.M.; BRANDI, R.M.; CANDIDO, J,F. e OLIVEIRA, L.M. Competição de espécies e procedências de eucalipto na região de Viçosa, Minas Gerais. ÁRVORE, Viçosa, 1 (2): 7288, Julho a Dezembro 1977.

KAGEYAMA, P.Y.; VENCOVSKY, R.; FERREIRA, M. e NICOLIELO, N. Variações genéticas entre procedências de $P$. oocarpa Schiede na região de Agudos-SP. IPEF, Piracicaba, (14): 77120, Julho 1977.

\section{8: 5 trabalhos}

BARRICHELO, L. E. G. ; KAGEYAMA, P. Y. ; SPELTZ, R. M. ; BONISH, H. J. ; BRITO, J. O. e FERREIRA, M. (1978). "Estudos de Procedências de $P$. taeda visando ao seu Aproveitamento Industrial." In: Congresso Florestal Brasileiro, 3. Amazonas, Dezembro, 1978 , p. 142-147.

FERREIRA, F.A. Situação do reflorestamento até julho de 1976 , nas regiões de maior ocorrência do cancro do eucalipto, nos estados do Espirito Santo e Minas Gerais, em termos de escolha de espécies e precedências de Eucalyptus. ÁRVORE, Viçosa, 2(1): 104-1 10, Janeiro a Julho 1978.

GURGEL FILHO, O. A. ; PIRES, C. L. S. ; GARRIDO, M. A. O. ; SIQUEIRA, A. C. M. F. ; FARIA, A. J. ; ASSINI, J. L . ; COELHO, L. C. C. ; FONTES, M. A. ; ROSA, P. R. F. ; FERNANDES, P. S. e SOUZA, J. M. (1978). "Teste de Procedência de Eucalyptus spp no Estado de São Paulo." In: Congresso Florestal Brasileiro, 3. Amazonas, Dezembro, 1978, p. 156-171.

NICOLIELO, N. e BERTOLANI, F. (1978b). "Estudo do Comportamento e da Variação Genética entre Procedências de $P$. oocarpa Schiede da Guatemala, na Região de Agudos-SP." In: Congresso Florestal Brasileiro, 3. Amazonas, Dezembro, 1978, p. 133-134.

SHIMIZU, J. Y (1978). "Testes Preliminares de Procedências de Pinus palustris Mill. no Sul do Brasil." In: Congresso Florestal Brasileiro, 3. Amazonas, Dezembro, 1978, p. 130-132.

1980: 2 trabalhos

BARROS, N.F.e BRANDI, R.M. Variações no crescimento de procedências de Pinus Kesiya Royle ex Gordon e P. merkusii Jungh et De Vriese, em Viçosa, M.G. ÁRVORE, Viçosa, 4(2): 124133, Julho a Dezembro 1980.

RESTREPO, G. e STÖHR, G.W.D. Resultados preliminares de ensaios de procedências de Eucalyptus spp. L'Heit. no sudeste do Paraná. FLORESTA, Curitiba, 11(1): 41-52, Junho 1980. 
GOMES, J.M.; PEREIRA, A.R.; BRANDI, R.M. e MACIEL, L.A.F. Variação do crescimento de espécies e procedências de eucalipto cultivados na região de Viçosa, MG. ÁRVORE, Viçosa, (2): 223-249, Julho a Dezembro 1981.

1982: 1 trabalho

URIBE, G.R. Ensaios de procedência de Eucalyptus spp. L'Herit. nas condições climáticas de dois locais do Estado do Paraná-Brasil. FLORESTA, Curitiba, 13(2): 33, Dezembro 1982.

1983: 7 trabalhos

ASSIS, T. F. ; BRUNE, A. e EUCLYDES, R. F. (1983). "Teste de Procedências de E. tereticornis no Vale do Rio Doce." In: Congresso Florestal Brasileiro; 4. Minas Gerais, Jan.-Fev. , 1983, p. 168-169.

ASSIS, T. F. ; BRUNE, A. e EUCLYDES, R. F. (1983). "Ensaio de Procedência de E. citriodora Hook." In: Congresso Florestal Brasileiro, 4. Minas Gerais, Jan.-Fev., 1983, p. 162-164.

CAMPINHOS JÚNIOR, E. ; IKEMORI, Y.K e MACIEL, R. (1983 a) "Teste de Procedência de $E$. grandis em Aracruz." In: Congresso Florestal Brasileiro, 4., p. 221, Minas Gerais, Jan.Fev., 1983.

FERREIRA, F.A. e SILVA, A.R. (1983) "Comportamento de Procedências de E. grandis e de $E$. saligna à Ferrugem (Puccinia psidii)." In: Congresso Florestal Brasileiro, 4., p. 287, Minas Gerais, Jan.-Fev, 1983.

GARNICA, J. B. ; NICOLIELO, N. e BERTOLANI, F. (1983). "Teste de Procedência de Pinus Kesiya na Região de Agudos-SP." In: Congresso Florestal Brasileiro, 4. Minas Gerais, Jan.-Fev. , 1983, p. 294-295.

GARNICA, J.B.; NICOLIELO, N. e BERTOLANI, F. (1983) "Teste de procedência de Pinus oocarpa na Região de Agudos, SP." In: Congresso Florestal Brasileiro, 4., p. 296, Curitiba, Paraná, 17 a 21 de Setembro, 1983.

MARTINS, F.C.G.; IKEMORI, Y.K.; CAMPINHOS, E.Jr e MACIEL, R. (1983) "Teste de Procedência de Pinus caribaea em Aracruz, E.S." In: Congresso Florestal Brasileiro, 4., p. 336, Minas Gerais, Jan.-Fev., 1983.

1986: 9 trabalhos

AMARAL, H. R. B. e SHIMUZU, J. (1986). "Variação entre procedência de $P$. elliottii var elliottii no Rio Grande do Sul." In: Congresso Florestal Brasileiro, 5. Pernambuco, Novembro, 1986, p. 114.

FAZZIO, E. C. M. ; JACOB, W. S. e SEITO, M. (1986). "Introdução de Espécies/Procedências de Eucalyptus na Região Amazônica." In: Congresso Florestal Brasileiro, 5. Pernambuco, Novembro, 1986, p. 114. 
FERREIRA, J. E. M. ; KROGH, H. J. O. ; MENK, A. L. M. e ODA, S. (1986). "Teste de Procedência de E. camaldulensis e E. tereteconis para a região sub. úmidas do Estado do Maranhão." In: Congresso Florestal Brasileiro, 5. Pernambuco, Novembro, 1986, p. 116.

FONSECA, A. G. ; SILVA, I. B. e GALVÃO, M. A. S. (1986). "Teste de Espécies e Procedências de Eucaliptos em Nísia Floresta, Estado do Rio Grande do Norte." In: Congresso Florestal Brasileiro, 5. Pernambuco, Novembro, 1986, p. 114.

FONSECA, A. G. ; BARBOSA, M. e LOBATO, R. C. (1986). "Ensaio de Procedências de Eucalyptus urophylla S.T. Blale." In: Congresso Florestal Brasileiro, 5. Pernambuco, Novembro, 1986, p. 114.

ODA, S.; FERREIRA, J.E.M.; KROGH, H.J.O.; MENCK, A.N.M. e KALIL, M.L.P. Introdução de espécies/procedência de Eucalyptus na região sub-úmida do Estado do Maranhão. IPEF, Piracicaba, (34): 57-61, Dezembro 1986.

SHIMIZU, J. Y. e AMARAL, H. R. B. (1986). "Variação entre procedência de $P$. taeda L. na região de Santa Maria-RS." In: Congresso Florestal Brasileiro, 5. Pernambuco, Novembro, 1986, p. 115.

TOledo FILHO, D. V. ; PIRES, C. L. S.; PARENTE, P. R. e ZANATTO, A. C. (1986). "Comportamento de híbrido $E$. grandis $\mathrm{x} E$. urophylla e de procedências de $E$. grandis, $E$. urophylla e E. umbra nas regiões de Mogi Mirim e Luiz Antônio." In: Congresso Florestal Brasileiro, 5. Pernambuco, Novembro, 1986, p. 114.

TOLEDO FILHO, D. V. ; PIRES, C. L. S. e ROSA, P. R. F. (1986). "Teste de Origens de Pinus Caribaea Mor." In: Congresso Florestal Brasileiro, 5. Pernambuco, Novembro, 1986, p. 114.

1988: 1 trabalho

MOURA, V.P.G.; MEIO, J.T. e SILVA, M.A. Comportamento de procedência de E. cloeziana F Muell aos nove e meio anos de idade, em Planaltina, DF, Ares do Cerrado. IPEF, Piracicaba, (46): $52-62,1988$.

1990: 1 trabalho

RIBEIRO, F. A. ; ZANI FILHO, J. e STAPE, J. L. (1990). "Comportamento silvicultural de procedência de E. saligna-Smith na região sul do Estado de São Paulo." In: Congresso Florestal Brasileiro, 6. , São Paulo, Setembro, 1990, p. 410-413.

1991: 1 trabalho

LIMA, R.T. Comportamento de espécies procedências tropicais do gênero Pinus em Felixlândia/MGBrasil, região de cerrados. ÁRVORE, Viçosa, 15(1): 1-9, Janeiro a Junho 1991.

1992: 2 trabalhos

FERREIRA, M.; SIMÕES, J.W; CANAVACA JÚNIOR e SANTOS, P.E.T. Teste de populações de $E$. phaeotricha Blakely e Makie em Anhembi, SP. IPEF, Piracicaba, (45): 1-13, 1992. 
SOUZA, S.M.; RESENDE, M.D.V.; SILVA, H.D. e HIGA, A.R. Variabilidade genética e interação genotipo $\mathrm{x}$ ambiente envolvendo procedências de $E$. cloeziana $\mathrm{F}$. Muell., em diferentes regiões do Brasil. ÁRVORE, Viçosa, 16(1): 1-17, Janeiro a Abril 1992.

1993: 5 trabalhos

MOURA, V. P. G. ; MELO, J. T. e SILVA, M. A. (1993). "Comportamento de procedências de Eucalyptus cloeziana F. Muell, aos nove e meio anos de idade, em Planaltina, DF., área de cerrado." In: Congresso Florestal Brasileiro, 7. , Paraná, Setembro, 1993, p. 97-103.

PIRES, C. L. S. ; SEBBENN, A. M. ; CUSTÓdIO FILHO, A. e ROCHA, F. T. (1993). "Variação genética entre origens de $P$. patula seh. et. dep. na Região de Angatuba-SP." In: Congresso Florestal Brasileiro, 7. , Paraná, Setembro, 1993, p. 161-162.

SAMPAIO, O. B. ; SILVA, L. M. M. e SOARES, F. A. L. (1993). "Comportamento de procedências de E. camaldulensis na Serra de Teixeira - Paraíba." In: Congresso Florestal Brasileiro, 7. , Paraná, Setembro, 1993, p. 726.

SCANAVACA JÚNIOR, L. ; GARCIA, C. H. e GOMES, F. S. (1993). "Comportamento de procedência/progênies de E. urophylla S.T. Blake, na Região de Jaú." In: Congresso Florestal Brasileiro, 7. , Paraná, Setembro, 1993, p. 104-105.

SEBBENN, A. M. ; PIRES, C. L. S. ; CUSTOdio FILHO, A. e PONTINHA, A. S. A. (1993). "Variação genética entre origens de $P$. patula seh. et. dep. na Região de Itapeva-SP." In: Congresso Florestal Brasileiro, 7. , Paraná, Setembro, 1993, p. 163-166.

1.2) Teste de Espécies

1971: 2 trabalhos

BALDANZI, G. e ARAÚJO, A.J. Ensaio comparativo de espécie e procedências de Pinus, na Estação de Pesquisas Florestais de Rio Negro, Paraná. FLORESTA, Curitiba, $\underline{3}$ (2): 86-89, Novembro 1971.

SPELTZ, R.M. Desenvolvimento do eucalipto na Fazenda Monte Alegre. FLORESTA, Curitiba, $\underline{3}(1)$ : 51-52, Maio 1971.

1972: 4 trabalhos

BERENHAUSER, G. Melhoramento genético de $P$. elliottii e $P$. taeda. FLORESTA, Curitiba, $\underline{3}$ (3): 1718, Junho 1972.

BERENHAUSER, G. Pinus elliottii contra Pinus taeda. FLORESTA, Curitiba, 4(1): 9-10, Dezembro 1972.

FERREIRA, M.; COUTO, H.T.Z. e MASCARENHAS SOBRINHO, J. Introdução de Pinus Mexicanos na região de Poços de Caldas. IPEF, Piracicaba, (4): 95-109, 1972.

FREITAS, E.R.; FERREIRA, M. e BORGES, C.P. Estudos das variações botânicas e povoamentos de $E$. alba REINW, E. saligna Smith , E. grandis Hill ex Maiden e E. propinqua Deane e Maiden. IPEF, Piracicaba, (4): 117-134, 1972. 
CAVALCANTI, G.R.A. e GURGEL, J.T.A. (1973) "Comportamento e Sobrevivência de Espécies de Eucalyptus no Horto Florestal Navarro de Andrade - Rio Claro." In: Congresso Florestal Brasileiro, 2., p. 84, Curitiba, Paraná, 17 a 21 de Setembro, 1973.

LEITE, N.B.; FERREIRA, M. RAMON, P.G. e GUTIERREZ, F.N. (1973) "Efeito de Geadas sobre Diversas Espécies/Progênies de Eucalyptus spp introduzidos na região de Lages - SC." In: Congresso Florestal Brasileiro, 2., p. 164, Curitiba, Paraná, Set. 1973.

OSSE, L e CONTI, A (1973) "Comportamento de Eucalyptus spp, na zona Metalúrgica de Minas Gerais." In: Congresso Florestal Brasileiro, 2., p. 47, Curitiba, Paraná, 17 a 21 de Setembro, 1973.

SPELTZ, R.M. e CORDEIRO, J.A. (1973) "Ensaio de Competição entre E. saligna Smith e $E$. camaldulensis em Solos de Baixadas." In: Congresso Florestal Brasileiro, 2., p.90, Curitiba, Paraná, 17 a 21 de Setembro, 1973.

SPELTZ, R.M. e RAUEN, V. (1973) "Ensaio de Competição entre Espécies de Eucalyptus." In: Congresso Florestal Brasileiro, 2., p. 96, Curitiba, Paraná, 17 a 21 de Setembro, 1973.

1975: 1 trabalho

PÁSZTOR, I.P.C. Estudo comparativo do comportamento das espécies de E. alba Reinu e E. decaisneana Blune, na região de São Paulo. IPEF, Piracicaba, (11): 1-16, Outubro 1975.

1976: 1 trabalho

BALDANZI, G. e MALINOVSKI, J.R. Ensaio comparativo de diferentes origens de $P$. taeda e $P$. elliottii. FLORESTA, Curitiba, 7(1): 5-8, 1976.

1977: 1 trabalho

GOMES, J.M.; BRANDI, R.M.; CANDIDO, J,F. e OLIVEIRA, L.M. Competição de espécies e procedências de eucalipto na região de Viçosa, Minas Gerais. ÁRVORE, Viçosa, 1 (2): 7288, Julho a Dezembro 1977.

1978: 3 trabalhos

BRANDI, R.M.; PAULA NETO, F. e BARROS, N.F. Competição de seis espécies de eucalipto em regimes de alto-fuste e de $1^{\text {a }}$ talhadia, cultivados na região de Viçosa, Minas Gerais. ÁRVORE, Viçosa, 2(1): 111-117, Janeiro a Julho 1978.

FERREIRA, F.A. Situação do reflorestamento até julho de 1976, nas regiões de maior ocorrência do cancro do eucalipto, nos estados do Espírito Santo e Minas Gerais, em termos de escolha de espécies e precedências de Eucalyptus. ÁRVORE, Viçosa, 2(1): 104-110, Janeiro a Julho 1978.

NICOLIELO, N. e BERTOLANI, F. (1978). "Estudo de Introdução de Espécies de Pinus na Região de Agudos-SP. "In: Congresso Florestal Brasileiro, 3. Amazonas, Dezembro, 1978, p. 128129. 
1979: 1 trabalho

CUNHA, R.A.; GURGEL, J.T.A. e PISANI, J.F. Estudo comparativo entre E. Atriodora Hook, $E$. maculata Hook e seus híbridos naturais. IPEF, Piracicaba, (18): 121-132, Junho 1979.

1981: 1 trabalho

GOMES, J.M.; PEREIRA, A.R.; BRANDI, R.M. e MACIEL, L.A.F. Variação do crescimento de espécies e procedências de eucalipto cultivados na região de Viçosa, MG. ÁRVORE, Viçosa, (2): 223-249, Julho a Dezembro 1981.

1986: 3 trabalhos

FONSECA, A. G. ; SILVA, I. B. e GALVÃO, M. A. S. (1986). "Teste de Espécies e Procedências de Eucaliptos em Nísia Floresta, Estado do Rio Grande do Norte." In: Congresso Florestal Brasileiro, 5. Pernambuco, Novembro, 1986, p. 114.

ODA, S.; FERREIRA, J.E.M.; KROGH, H.J.O.; MENCK, A.N.M. e KALIL, M.L.P. Introdução de espécies/procedência de Eucalyptus na região sub-úmida do Estado do Maranhão. IPEF, Piracicaba, (34): 57-61, Dezembro 1986.

PIRES, C. L. S. e PARENTE, P. R. (1986). "Competição de Espécies e Origens de Eucaliptos na Região de Mogi Mirim-SP." In: Congresso Florestal Brasileiro, 5. Pernambuco, Novembro, 1986, p. 114.

\section{3) Teste de Progênies}

1973: 2 trabalhos

LEITE, N.B.; FERREIRA, M. RAMON, P.G. e GUTIERREZ, F.N. (1973) "Efeito de Geadas sobre Diversas Espécies/Progênies de Eucalyptus spp introduzidos na região de Lages - SC." In: Congresso Florestal Brasileiro, 2., p. 164, Curitiba, Paraná, Set. 1973.

TEIXEIRA, M. B. e RAUEN,V. (1973) "Ensaio de competição entre progênies de E. saligna." In: Congresso Florestal Brasileiro, 2., p. 97, Curitiba, Paraná, 17 a 21 de Setembro, 1973.

1977: 1 trabalho

KAGEYAMA, P.Y.; SPELTZ, R.M.; SILVA, A.P. e FERREIRA, M. Variações genéticas entre e dentro de progênies de $P$. patula Schiede e Deppe na região de Telêmaco Borba-PR. IPEF, Piracicaba, (15): 21-39, Dezembro 1977.

1978: 2 trabalhos

KAgEYAMA, P. Y. ; BALlONI, E. e JACOB, W. S. (1978). "Teste de Progênies de E. grandis Resultados Preliminares." In: Congresso Florestal Brasileiro, 3. Amazonas, Dezembro, 1978, p. 125-127.

KAGEYAMA, P. Y. ; SPELTS, R. M. ; JACOB, W. S. e FERREIRA, M. (1978). "Variação Genética Entre e Dentro de Progênies de $P$. patula Schiede e Deppe na Região de Telêmaco Borba, PR." In: Congresso Florestal Brasileiro, 3. Amazonas, Dezembro, 1978, p. 135-138. 
1980: 1 trabalho

BORGES, R.C.G.; BRUNE, A.; SILVA, J.C. e REGAZZI, A.J. Estimativa de Parâmetros Genéticos em E. grandis W. Hill ex Maiden. ÁRVORE, Viçosa, 4(2): 134-145, Julho a Dezembro 1980.

\section{1: 1 trabalho}

ALMEIDA, C.M.V.C.; BRUNE, A.; SILVA, J.C. e OLIVEIRA, L.M. Estimativas de herdabilidades e correlações em progênies jovens de $E$. Citriodora Hook. ÁRVORE, Viçosa, $\underline{5}$ (2): 250-268, Julho a Dezembro 1981.

\section{3: 10 trabalhos}

ASSIS, T. F. ; BRUNE, A. e EUCLYDES, R. F. (1983). "Ensaio de Progênies de E. citriodora Hook." In: Congresso Florestal Brasileiro, 4. Minas Gerais, Jan.-Fev., 1983, p. 156-157.

ASSIS, T. F. ; BRUNE, A. e EUCLYDES, R. F. (1983). "Ensaio de Progênies de E. cloeziana F. MUELL." In: Congresso Florestal Brasileiro, 4. Minas Gerais, Jan.-Fev. , 1983, p. 158159.

ASSIS, T. F. ; BRUNE, A. e EUCLYDES, R. F. (1983). "Ensaio de Progênies de E. paniculata SM." In:: Congresso Florestal Brasileiro, 4. Minas Gerais, Jan.-Fev. , 1983, p. 160-161.

ASSIS, T. F. ; BRUNE, A. e EUCLYDES, R. F. (1983). "Teste de Progênies de E. grandis Hill ex Maiden." In: Congresso Florestal Brasileiro, 4. Minas Gerais, Jan.-Fev. , 1983, p. 165-167.

BRIGATTI, R.A.; FREITAS, M.; BEIG, O; DINIS, A.S. e FERREIRA, M. (1983a) "Teste de Progênie de Meios Irmãos de E. urophylla em área da Champion Papel e Celulose S.A." In: Congresso Florestal Brasileiro, 4., p. 209, Minas Gerais, Jan-Fev, 1983.

IKEMORI, Y.K.; CAMPINHOS Jr, E. e MACIEL, R. (1983) "Teste de Progênies de E. grandis procedentes de Atherton Tableland, Queensland (Austrália), na região de Aracruz, ES." In: Congresso Florestal Brasileiro, 4., p. 309, Minas Gerais, Jan.-Fev, 1983.

KAGEYAMA, P.Y. e VENCOVSKY, R. Variações genéticas em progênies de uma população de $E$. grandis (Hill) Maiden. IPEF, Piracicaba, (24): 9-26, Agosto 1983.

KALIL FILHO, A.N.; PIRES, C.L.S. e FONTES, M.A. (1983) "Análise de Comportamento e Estimação de Parâmetros Genéticos em Progênies de $P$. elliottii Engelm Var. elliottii na região de Itararé, SP." In: Congresso Florestal Brasileiro, 6., p. 325, Minas Gerais, Jan.Fev, 1983.

MENDES, F.S. Teste de progênies de árvores superiores de $P$. taeda selecionadas nos E.U.A. com alta capacidades geral de combinação. IPEF, Piracicaba, (25): 45-46, Dezembro 1983.

ROCHA, M.G.B.; BRUNE, A.; LUCIA, R.M.D. e OLIVEIRA, L.M. Variação da densidade básica e correlação entre caracteres progênies jovens de $E$. grandis Hill ex Maiden, em duas etapas de crescimento. ÁRVORE, Viçosa, Z(2): 154-164, Julho a Dezembro 1983. 
1985: 1 trabalho

OLIVEIRA, R.J.D.P. e BRUNE, A. Variação da densidade básica das madeira e capacidade de regeneração entre e dentro de origens de E. grandis W. Hill ex Maiden. ÁRVORE, Viçosa, 9(1): 40-48, Janeiro a Julho 1985.

1986: 4 trabalhos

IIJIMA, J. ; KAGEYAMA, P. Y. e PACHECO, R. M. (1986). "Estimativas de Parâmetros Genéticos em Progênie de Meios-Irmão de E. maculata Hook." In: Congresso Florestal Brasileiro, 5. Pernambuco, Novembro, 1986, p. 115.

MENCK, A.L.M.; ODA, A. e KAGEYAMA, P.Y. Variação Genética em progênies de árvores de pomar de sementes por mudas de $E$. grandis (Hill) Maiden na região de Biritiba Mirim-SP. IPEF, Piracicaba, (33): 5-15, Agosto 1986.

MORI, E. S. ; LELLO, L. R. D. e KAGEYAMA, P. Y. (1986). "Efeitos da Interação Genótipo x Ambiente em progênies de E. saligna Smith." In: Congresso Florestal Brasileiro, 5. Pernambuco, Novembro, 1986, p. 114.

MORI, E.Z.; LELLO, L.R.B. e KAGEYAMA, P.Y. Efeitos da interação genótipo x ambiente em progênies de E. saligna Smith. IPEF, Piracicaba, (33): 19-25, Agosto 1986.

1988: 2 trabalhos

MORI, E.S.; KAGEYAMA, P.Y. e FERREIRA, M. Variação genética e interação progênies x locais em E. urophilla. IPEF, Piracicaba, (39): 53-63, Agosto 1988.

VALERA, F.P. e KAGEYAMA, P.Y. Interação genótipo x espaçamento em progênies de E. saligna Smith. IPEF, Piracicaba, (39): 5-16, Agosto 1988.

1989: 1 trabalho

CANGIANI, S.M.P. e GONÇALVES, A.N. Caracterização e avaliação em viveiro de híbridos de polinização aberta de E. saligna x E. tereticornis. IPEF, Piracicaba, (41/42): 36-43, 1989.

1990: 1 trabalho

PIRES, I. E. ; BORGES, R. C. G. ; GOMES, J. M. e MARTINS, I. S. (1990). "Variabilidade genética em progênies de meio-irmãos de $E$. citriodora Hook, em condições de viveiro." In: Congresso Florestal Brasileiro, 6., São Paulo, Setembro, 1990, p. 471-473.

1992: 1 trabalho

DAVIDE, A.C. Avaliação da adaptabilidade e da estabilidade fenotípica de progênies de $E$. pellita F. Muel. FLORESTA, Curitiba, 21 (1/2): 83-84, Junho e Dezembro 1992. 
ARRIEL, N.H.C.; RAMALHO, M.A.P. e ANDRADE, H.B. Número de repetições e eficiência da seleção em progênies de meio-irmãos de E. camaldulensis. ÁRVORE, Viçosa, 17(2): 213223, Maio a Agosto 1993.

EQUIPE TÉCNICA DURATEX S/A (1993). "Teste de progênies de E. grandis de Itapetininga." In: Congresso Florestal Brasileiro, 7., Paraná, Setembro, 1993, p. 155-157.

REZENDE, G. D. S. P. e BERTOLUCCI, F. L. G. (1993). "Uso da seleção combinada na determinação da eficiência da seleção precoce em progênies de meios irmãos de E. urophylla." In: Congresso Florestal Brasileiro, 7. , Paraná, Setembro, 1993, p. 158-160.

SCANAVACA JÚNIOR, L. ; GARCIA, C. H. e GOMES, F. S. (1993). "Comportamento de procedência/progênies de E. urophylla S.T. Blake, na Região de Jaú." In: Congresso Florestal Brasileiro, 7. , Paraná, Setembro, 1993, p. 104-105.

XAVIER, A.; BORGES, R.C.G.; PIRES, I.E. e CRUZ, C.D. Variabilidade Genética de óleo essencial e de crescimento em progênies de meio-irmãos de E. citriodora Hook. ÁRVORE, Viçosa, 17(2): 224-234, Maio a Agosto 1993.

\section{4) Biotecnologia}

1986: 2 trabalhos

COELHO, L. C. C. ; TIMONI, J. L. ; BUZATTO, O. e BERTONI, J. E. A. (1986). "Experimentação com Pinus spp." In: Congresso Florestal Brasileiro, 5. Pernambuco, Novembro, 1986, p. 116.

SILVA, L.L.; TEIXEIRA, S.L.; CAMPOS, W.O. e CAPITANI, L.R. (1986) "Programa de Pesquisa em Cultura de Tecidos de Eucalyptus spp na Cenibra Florestal S.A." In: Congresso Florestal Brasileiro, 5., p. 63, Olinda, Pernambuco, 23 a 28 de Novembro, 1986.

1988: 1 trabalho

MENCK, A.L.M.; ODA, S.; LABOSQUE JÚNIOR, O. e KAGEYAMA, P.Y. Teste clonal a partir de árvores selecionadas em teste de progênies de E. saligna (resultados preliminares). IPEF, Piracicaba, (40): 27-32, Dezembro de 1988.

1990: 6 trabalhos

FANTINI JÚNIOR, M. e GRAÇA, M. E. C. (1990). "Propagação in vitro de E. saligna." In: Congresso Florestal Brasileiro, 6. , São Paulo, Setembro, 1990, p. 373-378.

INOVE, M. T. ; VIEIRA, J. D. e CORREA, G. (1990). "Estudo comparativo do desempenho fotossintético entre mudas micropropagadas e estaqueadas de 4 clones do híbrido $E$. grandis x E. urophylla." In: Congresso Florestal Brasileiro, 6., São Paulo, Setembro, 1990, p. 493495.

ONUKI, M. ; SILVA, A. R. e CARMO JÚNIOR, J. C. (1990). "Avaliação do programa clonal de Eucalyptus das Florestas Rio Doce S.A. - FRDSA." In: Congresso Florestal Brasileiro, 6. , São Paulo, Setembro, 1990, p. 353-356. 
PINEDO, D. N. H. ; GRAÇA, C. e ARAÚJO, A. J. (1990). "Micropropagação de $E$. citriodora e $E$. tereticornis." In: Congresso Florestal Brasileiro, 6. , São Paulo, Setembro, 1990, p. 361372.

SILVA, A. A. ; SIQUEIRA, A. C. M. F. ; ROMANALLI, R. C. e BERGAMASCO, A. (1990). "Produção de clones de Pinus spp através da enxertia em diferentes épocas do ano." In: Congresso Florestal Brasileiro, 6., São Paulo, Setembro, 1990, p. 380-385.

WIECHETECK, M.S.S. Micropropagação de E. viminalis Labill. a partir de material juvenil. FLORESTA, Curitiba, 20(1/2): 117-118, Junho e Dezembro 1990.

1992: 1 trabalho

FERREIRA, M.; Melhoramento e silvicultura intensiva clonal. IPEF, Piracicaba, (45): 22-30, 1992.

1993: 5 trabalhos

ASSIS, T. F. e GONÇALVES, S. I. (1993). "Micropropagação de E. grandis e E. saligna." In: Congresso Florestal Brasileiro, 7. , Paraná, Setembro, 1993, p. 727.

JESUS, R. M. ; PULEINELLI, C. E. e DÁRIO, F. R. (1993). "Competição clonal em Eucalyptus e estimativa de parâmetros genéticos." In: Congresso Florestal Brasileiro, 7., Paraná, Setembro, 1993, p. 91-93.

RESENDE, R. M. S. e GRAÇA, M. E. C. (1993). "Efeito de citocininas na multiplicação e no enraizamento de brotações de clones de $E$. grandis Hill ex Maiden cultivados in vitro. " In: Congresso Florestal Brasileiro, 7. , Paraná, Setembro, 1993, p. 116-118.

SOBRAL, B.W.S. (1993) "Biotecnologia no Melhoramento Genético das Espécies Florestais" Congresso Florestal Panamericano/Congresso Florestal Brasileiro, 1./7., p. 139, Curitiba, Paraná, 19 a 24 de Setembro, 1993.

TOTH, V. B. R. ; GONÇALVES, A. N. e VIEIRA, J. D. (1993). "Efeito da interação de auxina e esteróides no alongamento e enraizamento de clones de híbridos de Eucalyptus in vitro." In: Congresso Florestal Brasileiro, 7., Paraná, Setembro, 1993, p. 110-112.

\section{5) Outros}

1970: 1 trabalho

SUITER FILHO, W. Influência da posição do ramo da copa na enxertia de $P$. elliottii Engel e $P$. taeda L. .IPEF, Piracicaba, (1): 121-124, Janeiro a Junho 1970.

1973: 1 trabalho

BORGES, C.P.; SILVA, A.A. e FERREIRA, M. Estudos preliminares sobre a conservação de polén de Eucalyptus spp. IPEF, Piracicaba, (6): 3-32, 1973. 
POGGIANI, F. e SUITER FILHO, W. Importância da Nebulização intermitente e efeito do tratamento hormonal na formação de raízes em estacas de eucalipto. IPEF, Piracicaba, (9): 119-129, Dezembro 1974.

1977: 2 trabalhos

BORGES, E.E.L. e COLLOM, J.L. Períodos de queda de sementes de E. grandis híbrido, na região de Viçosa. ÁRVORE, Viçosa, 1 (1): 26-30, Março 1977.

BRUNE, A. Enxertia de E. grandis Maiden ex Hook. ÁRVORE, Viçosa, 1(1): 55-56, Março 1977.

1978: 3 trabalhos

FONSECA, S.M. e KAGEYAMA, P.Y. Bases genéticas e metodologia para seleção de árvores superiores de $P$. taeda. IPEF, Piracicaba, (17): 35-59, Dezembro 1978.

HIGA, A.R.; MOURA, A.L.; BORTOLOTI, G. e CONÇALVES, A.N. Borbulha dupla em E. urophylla S.T. Blake. IPEF, Piracicaba, (17): 1-9, Dezembro 1978.

HIGA, A. R. ; MORA, A. L. e BERTOLOTI, G. (1978). "Enxertia em E. urophylla por Borbulha Dupla." In: Congresso Florestal Brasileiro, 3. Amazonas, Dezembro, 1978, p. 153-155.

1979: 1 trabalho

PEREIRA, J.A.A.; BRUNE, A. e BORGES, E.E.L. Enraizamento de estacas de E. saligna e E. grandis

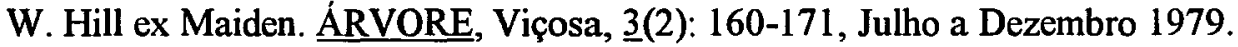

1980: 1 trabalho

MORA, A.L.; BERTOLOTTI, G.; PINTO JÚNIOR, J.E. e KAGEYAMA, P.Y. Enxertia em Pinus kesiya. IPEF, Piracicaba, (21): 1-16, Dezembro 1980.

1981: 1 trabalho

BORGES, R.C.G.; BRUNE, A. Estudo de herdabilidade quanto à resistência a Diaporthe cubensis Bruner em E. grandis W. Hill ex Maiden. ÁRVORE, Viçosa, $\underline{5}(1)$ : 115-120, Janeiro a Junho 1981.

1982: 1 trabalho

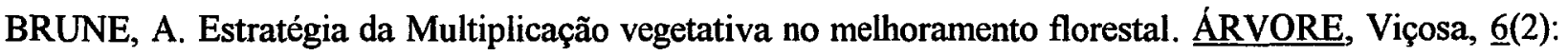
162-165, Julho a Dezembro 1982.

1983: 6 trabalhos

ASSIS, T. F.; ULHOA, M.A.; NOVELLI, A.B. e NASCIMENTO, M.B.Fo (1983) "Enxertia em Eucalyptus spp." In: Congresso Florestal Brasileiro, 4., p. 170, Minas Gerais, Jan-Fev., 1983. 
BRIGATTI, R.A.; FERREIRA, M.; BEIG, O. e FREITA, M. (1983 b) "Polinização Controlada em $E$. urophylla - Um Programa Desenvolvido pela Champion Papel e Celulose S.A." In: Congresso Florestal Brasileiro, 4., p. 213, Minas Gerais, Jan-Fev, 1983.

CHAVES, R.; KAGEYAMA, P.Y e COUTO, H.T.Z. Estimativa da variação genética e da herdabilidade para o florescimento em $P$. caribaea var. hondurensis Barr. e Golf. e em P.oocarpa Shiede. IPEF, Piracicaba, (25): 15-23, Agosto 1983.

IKEMORI, Y.K. e CAMPINHOS, E.Jr (1983 ) "Produção de Sementes de E. grandis x E. urophylla por Polinização Aberta." In: Congresso Florestal Brasileiro, 4., p. 306, Minas Gerais, Jan.-Fev., 1983.

ODA, S. e FERREIRA, M. (1983) "Producão de Hibridos Interespecíficos de Eucaliptos por Polinização Aberta." In: Congresso Florestal Brasileiro, 4., p. 407, Minas Gerais, Jan.-Fev., 1983.

ODA, S.; GONÇALVES, A.N. e KAGEYAMA, P.Y.(1983) "Florescimento em Estacas de E. grandis aos 14 meses de Idade." In: Congresso Florestal Brasileiro, 4., p. 409, Minas Gerais, Jan.Fev., 1983.

1984: 1 trabalho

JANI FILHO, J. e KAGEYAMA, P.Y. A produção de sementes melhoradas de espécies florestais com ênfase em Eucalyptus. IPEF, Piracicaba, (27): 49-52, Agosto 1984.

1985: 1 trabalho

PACHECO, I.A.; KAGEYAMA, P.Y.; BERTI FILHO, E. e WIENDL, F.M. Efeitos de colméia de Apis mellifera em pomares de sementes de $E$. saligna Smith. IPEF, Piracicaba, (29): 11-18, Abril 1985.

1986: 5 trabalhos

PACHECO, I.A.; KAGEYAMA, P.Y.; WIENDL, F.M. e BERTI FILHO, E. Estudo da dispersão de pólen de $E$. saligna Smith por abelhas Apis mellifera L. utilizando-se o radiofosforo 32p. IPEF, Piracicaba, (34): 47-52, Dezembro 1986.

RODRIGUES, L.C.; VASTANO, B.Jr e SILVA, A.P. (1986) "Manejo e Melhoramento de Florestas de Eucalyptus em Areias Quartzosas na Região Nordeste do Estado de São Paulo." In: Congresso Florestal Brasileiro, 5., p. 104, Olinda, Pernambuco, 23 a 28 de Novembro, 1986.

SHIMIZU, J. Y. (1986). "Estabilidade Genotípica e Adaptabilidade como Critérios para Seleção de $P$. elliottii." In: Congresso Florestal Brasileiro, 5. Pernambuco, Novembro, 1986, p. 115.

SHIMIZU, J.Y. (1986) "Estabilidade Genotípica e Adaptabilidade como Critérios para Seleção de $P$. elliottii." In: Congresso Florestal Brasileiro, 5., p. 115, Olinda, Pernambuco, 23 a 28 de Novembro, 1986.

ZANI FILHO, J. ; BALLONI, E. A. e KAGEYAMA, P. Y. (1986). "Manejo de áreas produtoras de sementes visando a operacionalização de programas de melhoramento genético baseados em 
multipopulações." In: Congresso Florestal Brasileiro, 5. Pernambuco, Novembro, 1986, p. 116.

1987: 1 trabalho

KAGEYAMA, P.Y. Conservação "in situ" de recursos genéticos das plantas. IPEF, Piracicaba, (35): 737, Abril de 1987.

1988: 2 trabalhos

BLAKE, T.; BEVILACQUA, E. e BARBOSA, M.M. Seleção precoce de clones e espécies de Eucalyptus de rápido crescimento. IPEF, Piracicaba, (40): 5-14, Dezembro de 1988.

ZANI FILHO, J. e BALLONI, E.A. Enraizamento de estacas de Eucalyptos: efeitos do substrato e do horário de coleta do material vegetativo. IPEF, Piracicaba, (40): 39-42, Dezembro 1988.

1989: 3 trabalhos

KAGEYAMA, P.Y. e CASTRO, A. Sucessão secundária, estrutura genética e plantação de espécies arbóreas nativas. IPEF, Piracicaba, (41/42): 83-93, 1989.

ODA, S.; MENCK, A.L.M. e VENCOVSKY, R. Problemas de melhoramento genético clássicos do eucalypto em funcão da alta densidade de seleção. IPEF, Piracicaba, (41/42): 8-26, 1989.

SOUZA, V.A. e PINTO JÚNIOR, J.E. Receptividade estigmática em Eucalyptus dumii. IPEF, Piracicaba, (47): 44-49, Maio 1989.

1990: 4 trabalhos

COOPER, M.A. Maximização do potencial de enraizamento de estacas de E. dunni Maiden. FLORESTA, Curitiba, 20(1/2): 104-105, Junho e Dezembro 1990.

MENCK, A.L.M.; MARCHI, E.L.; KOVALSKI, M.E. Influência do sistema de coleta de botões florais na viabilidade do polén de Eucalyptus ssp. IPEF, Piracicaba, (43/44): 20-23, 1990.

SANTOS, P.E.T.; MORI, E.S. e MORAES, M.L.T. Potencial para programas de melhoramento, estimativas de parâmetros genéticos e interações progênies $\mathbf{x}$ locais em populações de $E$. urophylla S.T. Balke. IPEF, Piracicaba, (43/44): 11-19, 1990.

ZANI FILHO, J. ; STAPE, F. L. ; RIBEIRO, F. A. e BALLONI, E. A. (1990). "Programa de melhoramento genético de $E$. urophylla $\mathrm{S}$. T. Blake através de seleção precoce." In: Congresso Florestal Brasileiro, 6. , São Paulo, Setembro, 1990, p. 464-470.

1993: 8 trabalhos

CORDER, M. M. e LOPES, C. R. (1993). "Análise genética de padrões isoenzimáticos de Eucalyptus spp em diferentes estágios de desenvolvimento." In: Congresso Florestal Brasileiro, 7. , Paraná, Setembro, 1993, p. 82-83. 
DAVIDE, L.C.D. ARAÚJO, A.J. Características cromossômica para a identificação de fenótipos diferentes em povoamento de P. oocarpa Schiede. ÁRVORE, Viçosa, 17(3): 327-338, Setembro a Dezembro 1993.

FANTINI JÚNIOR, M. e KIKUTI, P. (1993). "Propagação vegetativa de $P$. taeda L. por estaquia em Telêmaco Borba-PR." In: Congresso Florestal Brasileiro, 7. , Paraná, Setembro, 1993, p. 152-154.

HIGA, A. R. e RESENDE, M. D. V. (1993). "Melhoramento genético de Eucalyptus spp na Embrapa." In: Congresso Florestal Brasileiro, 7., Paraná, Setembro, 1993, p. 727.

MENCK, A. L. M. ; MELlo, E. J. ; ODA, S. e GONÇALVES, A. N. (1993). "Indução de florescimento precoce de Eucalyptus spp, com o uso de paclobutrazol - resultados preliminares." In: Congresso Florestal Brasileiro, 7. , Paraná, Setembro, 1993, p. 123-126.

RESENDE, M. D. V. ; HIGA, A. R. e LAVORANTI, O. J. (1993). "Predição de valores genéticos no melhoramentos de Eucalyptus - melhor predição linear." In: Congresso Florestal Brasileiro, 7. , Paraná, Setembro, 1993, p. 144-147.

SOUZA, V. A. e PINTO JÚNIOR, J. E. (1993). "Desenvolvimento de tubo polínico de E. dunnii Maiden, em diferentes meios de cultura." In: Congresso Florestal Brasileiro, 7. , Paraná, Setembro, 1993, p. 106-109.

SOUZA, V. A. e PINTO JÚNIOR, J. E. (1993). "Floração de E. dunnnii Maiden em diferentes posições da copa." In: Congresso Florestal Brasileiro, 7. , Paraná, Setembro, 1993, p. 119-122.

\section{2) Produção de Mudas}

1970: 4 trabalhos

BAENA, E.S. A produção de mudas na Fazenda Monte Alegre (Viveiro Lagoa). FLORESTA, Curitiba, 2(3): 37-43, Dezembro 1970.

MELLO, H.A.; MASCARENHAS SOBRINHO, J.; SIMIÕES, J.W e COUTO, H.T.Z. Resultados da aplicação de fertilizantes minerais na produção de mudas de $E$. saligna $\mathrm{Sm}$ em solo de cerrado do Estado de São Paulo. IPEF, Piracicaba, (1): 7-26, Janeiro a Junho 1970.

SIMÕES, J.W. Métodos de Produção de mudas de eucalipto. IPEF, Piracicaba, (1): 101-116, Janeiro a Junho 1970.

SIMÕES, J.W.; MELLO, H.A. e JUNQUEIRA, R.A. Tratamento do solo e seu efeito sobre o desenvolvimento de mudas de eucaliptos e pinus. IPEF, Piracicaba, (1): 129-140, Janeiro a Junho 1970.

1971: 4 trabalhos

CARNEIRO, J.G.A. Ensaio sobre quebra de dormência de semente de $P$. caribaea var. hondurensis. FLORESTA, Curitiba, $\underline{3}$ (2): 43-67, Novembro 1971.

GLASER, G.R. Semeadura de P. elliottii. FLORESTA, Curitiba, 3(1): 59-68, Maio 1971. 
MILLER, W.F. Período de estratificação para $P$. elliottii. FLORESTA, Curitiba, $\underline{3}(2)$ : 83-84, Novembro 1971.

SIMÕES, J.W.; SPELTZ, R.M.; SPELTZ, G.E. e MELLO, H.A. Adubação Mineral na formação de mudas de eucalipto. IPEF, Piracicaba, (2/3): 35-49, 1971.

1972: 2 trabalhos

BRASIL, U.M.; SIMÕES, J.W. e SPELTZ, R.M. Tamanho adequado de tubetes de papel na formação de mudas de eucalipto. IPEF, Piracicaba, (4): 29-34, 1972.

INOVE, M.T. Ensaio comparativo para dimensionar as influências causadas pela inoculação de fungos micorrízicos em mudas de $P$. taeda $\mathbf{L}$. em relação à quantidade de inóculo presente no solo. FLORESTA, Curitiba, 4(1): 63-68, Dezembro 1972.

1973: 2 trabalhos

BRASIL, U.M.; SIMÕES, J.W. Determinação da dosagem de fertilizante mineral para a formação de mudas de eucalipto. IPEF, Piracicaba, (6): 79-85, 1973.

SUITER FILHO, W. e LISBÃO JÚNIOR, L. Influência da umidade relativa nas características umidade, germinação, vigor e peso específico das sementes de $E$. saligna, Sm. IPEF, Piracicaba, (6): 39-54, 1973.

1974: 1 trabalho

AGUIAR, I.B. e MELLO, H.A. Influência do recipiente na produção de mudas e no desenvolvimento inicial após o plantio no campo de $E$. grandis Hill ex Maiden e E. saligna Smith., IPEF, Piracicaba, (8): 19-40, Outubro 1974.

1975: 2 trabalhos

BERTOLANI, F.; VILELA FILHO, A.; NICOLIELO, N.; SIMÕES, J.W.; BRASIL, U.M. Influência dos recipientes e dos métodos de Semeadura na formação de mudas de $P$. caribaea Moralet var Hondurensis. IPEF, Piracicaba, (1 1): 71-77, Outubro 1975.

CARNEIRO, J.G.A. e ROCHA, F. Efeitos de alguns produtos em ação pós-emergente em mudas de $P$. taeda, L. FLORESTA, Curitiba, 6(1): 43-48, 1975.

\section{7: 2 trabalhos}

BARROS, N.F.; BRANDI, R.M.; COUTO, L. e FONSECA, S.M. Aplicação de fertilizantes minerais na formação de mudas de $E$. grandis Maiden ex Hook através da água da irrigação. ÁRVORE, Viçosa, 1 (1): 17-25, Março 1977.

BRAGA, J.M.; COUTO, L.; NEVES, M.J.B. e BRANDI, R.M. Comportamento de Mudas de Eucalyptus spp. em viveiro, em relação à aplicação de $\mathrm{N}, \mathrm{P}, \mathrm{K}$ e diferentes fontes de fósforo. ÁRVORE, Viçosa, 1 (2): 135-148, Julho a Dezembro 1977. 
1978: 13 trabalhos

BALLONI, E. A. ; KAGEYAMA, R. Y. e CORRADINE, L. (1978). "Efeito do Tamanho da Semente de E. grandis sobre Vigor das Mudas no Viveiro e no Campo." In: Congresso Florestal Brasileiro, 3. Amazonas, Dezembro, 1978, p. 41-43.

CARNEIRO, J.G.A. Determinação do padrão de qualidade de mudas de $P$. taeda, L. para plantio definitivo. FLORESTA, Curitiba, $\underline{8}(1)$ : 63-67, 1978.

FARIA, A. B. ; REZENDE, G. C. ; MENDES FILHO, J. M. A. e SUITER FILHO, W. (1978). "Uso de Aldrin em Mudas de Eucalyptus." In: Congresso Florestal Brasileiro, 3. Amazonas, Dezembro, 1978, p. 365-366.

GERGEMANN, I. ; CARVALHO, N. M. e SIMÕES, M. S. (1978). "Efeito da Estratificação, em Soluções de Ácido Gibérelico, sobre a Germinação de $P$. taeda, L." In: Congresso Florestal Brasileiro, 3. Amazonas, Dezembro, 1978, p. 44-46.

GOMES, J. M. ; BRANDI, R. M. ; COUTO, L. e BARROS, N. F. (1978). "Efeito de Sombreamento e Tipos de Suportes para Fertil-Pot na Produção de Mudas de E. grandis W. Hill ex Maiden." In: Congresso Florestal Brasileiro, 3. Amazonas, Dezembro, 1978, p. 352-354.

GOMES, J. M. ; REZENDE, G. C. ; SOUZA, A. L. e NOVAIS, R. F. (1978). "Métodos de Aplicação de Adubos na Formação de Mudas de E. grandis (Hill) ex Maiden." In: Congresso Florestal Brasileiro, 3. Amazonas, Dezembro, 1978, p. 385-386.

GOMES, J. M. ; SOUZA, A. L. ; PAULA NETO, F. e REZENDE, G. C. (1978). "Influência do tamanho da Embalagem Plástica na Formação de Mudas de E. grandis W. Hill ex Maiden." In: Congresso Florestal Brasileiro, 3. Amazonas, Dezembro, 1978, p. 387-388.

GOMES, J.M.; BRANDI, R.M.; CANO, M.A.O. e SOUZA, A.P. Efeitos do sal, antitranspitante e poda no endurecimento à seca de mudas de $E$. grandis W. Hill ex Maiden. FLORESTA, Curitiba, 9 (1): 18-24, 1978 .

KANASHIRO, M.; KAGEYAMA, P.Y. e MARQUES, F.C.M. Peletilização de sementes de Eucalyptus spp. IPEF, Piracicaba, (17): 63-73, Dezembro 1978.

MARQUES, F. ; KAGEYAMA, R. Y. e NICOLIELO, N. (1978). "Quebra de Dormência em Sementes de $P$. caibaea Var. bahamensis." In: Congresso Florestal Brasileiro, 3. Amazonas, Dezembro, 1978, p. 32-33.

MENDES, C. J. ; CÂNDIDO, J. F. ; REZENDE, G. C. e SUITER FILHO, W. (1978). "Tamanho de Sementes de E. grandis (Hill) Maiden e seu Efeito sobre a Germinação e Qualidade de mudas." In: Congresso Florestal Brasileiro, 3. Amazonas, Dezembro, 1978, p. 344-347.

REZENDE, G. C. ; SUITER FILHO, W. e GUSMÃO, A. D. (1978). "Resultados Preleminares Sobre a Influência do Tipo de Muda no Crescimento do E. grandis (Hill) ex Maiden." In: Congresso Florestal Brasileiro, 3. Amazonas, Dezembro, 1978, p. 383-384.

VENTORIM, N. (1978). "Efeito de Recipientes no Desenvolvimento de Mudas de E. grandis Hill ex Maiden." In: Congresso Florestal Brasileiro, 3. Amazonas, Dezembro, 1978, p. 357-358. 
1979: 4 trabalhos

FONSECA, A.G.; BRANDI, R.M.; PAULA NETO, F. e CANDIDO, J.F. Efeito do Sombreamento, o tamanho e peso da semente na produção de mudas de $E$. grandis W. Hill ex Maiden e no eu crescimetno inicial no campo. ARVORE, Viçosa, $\underline{3}(2)$ : 145-159, Julho a Dezembro 1979.

GOMES, J.M.; BRANDI, R.M.; COUTO, L. e BARROS, N.F. Efeitos de recipientes e substratos na

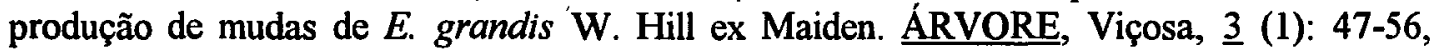
Janeiro a Julho 1979.

GOMES, J.M.; RESENDE, G.C.; SOUZA, A.L. e NOVAIS, R.F. Métodos de aplicação de adubos na formação de mudas de E. grandis W. Hill ex Maiden. FLORESTA, Curitiba, 10(1): 21-23, 1979.

NOVAIS, R.F.; GOMES, J.M.; ROCHA, D. e BORGES, E.E.L. Calagem e Adubação mineral na produção de mudas de eucalipto. (E. grandis W. Hill ex Maides). I. Efeitos da calagem e dos nutrientes N, P e K. ÁRVORE, Viçosa 33(2): 121-134, Julho a Dezembro 1979.

1980: 2 trabalhos

NOVAIS, R.F.; GOMES, J.M.; NASCIMENTO FILHO, M.B. e BORGES, E.E.L. Calagem e adubação mineral na produção de mudas de eucalipto (E. grandis W. Hill ex Maides). III. Efeitos da calagem, do superfosfato simples e de um fertilizante NPK. ÁRVORE, Viçosa, 4(2): 111-123, Julho a Dezembro 1980.

TOMAZELLO FILHO, M. e KRÜGNER, T.L. Formação de ectomicorrizas e crescimento de mudas de $P$. caribaea var. bahamensis em solo de viveiro infestado artificialmente com Fhelephora terrestris e Pisolithus tinctoruis no litoral Sul da Bahia. IPEF, Piracicaba, (21): 85-95, Dezembro 1980.

1981: 5 trabalhos

ANJOS, N.; LUDWIG, A.; SANTOS, G.P. e MOREIRA, J.F. Eficiência de três produtos químicos e de um processo mecânico do controle de lagartas-posca em mudas de $E$. grandis Hill ex Maiden. ÁRVORE, Viçosa, 5(2): 218-223, Julho a Dezembro 1981.

FERREIRA, M.G.M.; CANDIDO, J.F.; SILVA, D.A. e COLODETTE, J.L. Efeito do sombreamento e da densidade de sementes sobre o desenvolvimento de mudas de $P$. insularis Endlicher e seu crescimento inicial no campo. FLORESTA, Curitiba, 12(1): 53-61, Junho 1981.

OLIVEIRA, O.S. e BARROS, P.LC. A influência das Micorrizas na formação de mudas de $P$. caribaea Morelet var. hondurenses. FLORESTA, Curitiba, 12(1): 66-71, Junho 1981.

PEREIDA, A.R.; OLIVEIRA, A.C. e MORAES, E.J. Estudos de tipos de cobertura na produção de mudas de E. grandis W. Hill ex Maiden. FLORESTA, Curitiba, 12(1): 49-52, Junho 1981.

PEREIRA, A.R. e BRANDI, R.M. Influência do recipiente plástico na sobrevivência de mudas de

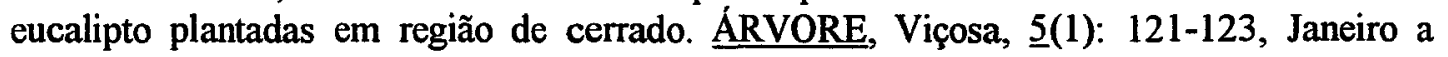
Junho 1981. 
1982: 5 trabalhos

BALENSIEFER, M. Estudo de diferentes métodos de plantio com $P$. taeda na região de GuarapuavaParaná. FLORESTA, Curitiba, 13(2): 39, Dezembro 1982.

GOMES, J.M.; BARROS, N.F.; NEVES, J.C.L.; NOVAIS, R.F. e MACIEL, L.A.F. Métodos de plicação de adubo em diferentes solos para a produção de mudas de $E$. grandis W. Hill ex Aiden. ÁRVORE, Viçosa, 6(1): 52-63, Janeiro a Junho 1982.

MATTEI, V.L. Viabilidade técnica da produção de mudas de $P$. elliottii Engelm., em moldes de isopor "Styroblocks". FLORESTA, Curitiba, 13(2): 47-49, Dezembro 1982.

OLIVEIRA, O.S. Efeitos da terra micorrizada sobre o desenvolvimento de mudas de Pinus taeda L. e Pinus patula Sch e Cham. FLORESTA, Curitiba, 13(2): 40, Dezembro 1982.

ZAMBOLIM, L.; BARROS, N.F. e COSTA, L.M. Influência de micorrizas do tipo vesicular-arbuscular no crescimento e absorção de nutrientes por mudas de Eucalyptus spp. ÁRVORE, Viçosa, 6(1): 64-75, Janeiro a Junho 1982.

1983: 12 trabalhos

BRAGA, J.M. e ROCHA, D. (1983) "Adubação Fosfatada em Eucalipto no Viveiro, II - Efeito da Época de Aplicação de Calcário e de Gesso na Eficiência dos Fosfatos de Araxá e de Patos." In: Congresso Florestal Brasileiro, 4., p. 195, Minas Gerais, Jan.Fev., 1983.

CAMPINHOS JÚNIOR, E. e IKEMORI, I.K. Nova técnica para a produção de mudas de essências florestais. IPEF, Piracicaba, (23): 47-52, Abril 1983.

CAMPINHOS, E. Jr e IKEMORI, Y.K. (1983) "Introdução de Nova Técnica na Produção de Mudas de Essências Florestais." In: Congresso Florestal Brasileiro, 4., p. 226, Minas Gerais, Jan.Fev., 1983.

FAÇANHA, J.G.V. e OLIVA, M.A. (1983) "Germinação de Eucalyptus spp sob Condições de stress hídrico." In: Congresso Florestal Brasileiro, 4., p.276, Minas Gerais, Jan.-Fev., 1983.

FERNANDES, P.S.; BAENA, E.S; COUTINHO, C.J. e GONÇALVES, J.C. (1983 a) "Utilização de Vermiculita no Plantio de Essências Florestais." In: Congresso Florestal Brasileiro, 4., p. 282, Minas Gerais, Jan.-Fev., 1983.

FERNANDES, P.S.; COUTINHO, C.J. e BAENA, E.S. (1983 b) "Produção de Mudas de E. saligna em Bandeijas de Isopor ." In: Congresso Florestal Brasileiro, 4., p. 285, Minas Gerais, Jan.Fev., 1983.

MOURA, V.P.G. (1983 a) "Efeito da Temperatura na Germinação de Sementes de E. urophylla S.T. Blake." In: Congresso Florestal Brasileiro, 4., p. 376, Minas Gerais, Jan.-Fev., 1983.

MOURA, V.P.G. (1983 b) "Influências da Altitude no Tamanho de Sementes e no Crescimento de Mudas de E. urophylla S.T. Blake." In: Congresso Florestal Brasileiro, 4., p. 382, Minas Gerais, Jan.-Fev., 1983. 
OSÓRIO, R.G.S. e FERNANDES, P.S. (1983) "Estudo sobre a Dosagem de Sementes Purificadas de $E$. saligna Smith em Alfobres." In: Congresso Florestal Brasileiro, 4., p. 411, Minas Gerais, Jan.-Fev., 1983.

PEREIRA, A.R. e GOMES, J.M. (1983) "Influência do Tamanho de Sementes no Crescimento de mudas Eucalyptus spp." In: Congresso Florestal Brasileiro, 4., p.418, Minas Gerais, Jan.-Fev., 1983.

PEREIRA, A.R.; GOMES, J.M.; COSTA, R.L e CASTRO, F.P. (1983 a) "Influência da Extração de Recipientes Plásticos no Crescimento de Eucalytpus na Região do Cerrado." In: Congresso Florestal Brasileiro, 4., p. 427, Minas Gerais, Jan.-Fev., 1983.

SILVA, H.D.; PIRES, I.E. e SOUZA, S.M. (1983) "Influência da Espessura e Tipo de Material da Cobertura na Produção de Mudas de E. citriodora Hook." In: Congresso Florestal Brasileiro, 4., p. 494, Minas Gerais, Jan.-Fev., 1983.

1984: 2 trabalhos

LOCATELLI, M.; BARROS, N.F.; BRANDI, R.M.; NEVES, J.C.L. e GOMES, J.M. Efeito de fontes e doses de nitrogênio no crescimento de mudas de eucalipto. ÁRVORE, Viçosa, $\underline{8}(1): 39-52$, Janeiro a Junho 1984.

LOCATELLI, M.; BARROS, N.F.; NEVES, J.C.L. e NOVAIS, R.F. Efeito de forma de nitrogênio

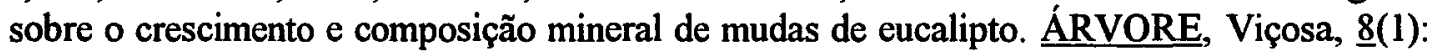
53-69, Janeiro a Junho 1984.

1985: 1 trabalho

GOMES, J.M.; COUTO, L. e PEREIRA, A.R. Uso de diferentes substratos na produção de mudas e $E$. grandis em tubetes e em bandejas de isopor. ÁRVORE, Viçosa, 9 (1): 58-86, Janeiro a julho 1985.

1986: 4 trabalhos

BARROS, N.F.; NOVAIS, R.F.; CARMO, D.N. e NEVES, J.C.L. Classificação nutricional de sítios florestais - descrição de uma metodologia. ÁRVORE, Viçosa, 10(1): 112-120, Janeiro a Junho 1986.

BETTIOL, W.; ALVER, C.G.; KRUGNER, T.L. e PREZOTTO, M.E.M. Influência de lodo de esgoto e de acículas de Pinus na formação de ectomicorrizas em mudas de $P$. caribaea var honduensis pelos fungos Pisolithus tinctorius e Thelephora terrestris. IPEF, Piracicaba, (34): 41-46, Dezembro de 1986.

BORGES, E.N.; NOVAIS, R.F.; BARROS, N.F.; COSTA, L.M. e NEVES, J.C.L. Respostas de Mudas de eucalipto a camadas compactadas de solo. ÁRVORE, Viçosa, 10(2): 181-195, Julho a Dezembro 1986. 
FERNANDES, P. S. ; FERREIRA, M. C. e STAPE, J. L. (1986). "Sistemas Alternativos de Produção de Mudas de Eucalyptus." In: Congresso Florestal Brasileiro, 5. Pernambuco, Novembro, 1986, p. 73.

1988: 1 trabalho

BACCHI, L.M.A. e KRÜGNER, T.L. Desenvolvimento ectomicorrizico em mudas de E. grandis e $E$. urophylla inoculados com Pisolithus tinctoruis em um viveiro comercial. IPEF, Piracicaba, (40): 21-26, Dezembro de 1988.

1989: 2 trabalhos

AGUIAR, I.B.; VALERI, S.A.; BANZATTO, D.A.; CORRADINE, L. e ALVARENGA, S.F. Seleção de componentes de substrato para a produção de muda em tubetes. IPEF, Piracicaba, (41/42): 36-43, 1989.

SOARES, I; BORGES, A.C.; BARROS, N.F.; NEVES, J.C. e BELLEI, M.M. Teor de fósforo no solo influenciando o desenvolvimento de ectomiconizas e nutrição e crescimento de mudas de eucalipto. ÁRVORE, Viçosa, 13(2): 140-151, Julho a Dezembro 1989.

1990: 4 trabalhos

BEGA, O.A. Inoculação de mudas de mudas de $P$. taeda por Sclerodem. FLORESTA, Curitiba, 20(1/2): 80-81, Junho e Dezenbro 1990.

FERREIRA, F.A.S. e MARCHETTI, E.R. (1990) "Viveiro Suspenso da Riocell: racionalização do quadro de mão-de-obra através da implantação de um sistema de producão de mudas com usos múltiplos." In: Congresso Florestal Brasileiro, 6., p.29, Campos do Jordão, São Paulo, 27 de Setembro, 1990.

GOULART, R. V. ; TEIXEIRA, J. L. ; NOVAIS, R. F. ; BARROS, N. F. e MACEDO, P. R. O. (1990). "Respostas de Mudas de Eucalyptus spp à calagem." In: Congresso Florestal Brasileiro, 6., São Paulo, Setembro, 1990, p. 456-458.

JANKOVSKI, J. Avaliação da produção e disseminação de sementes em um povoamento de $P$. taeda $\mathrm{L}$. FLORESTA, Curitiba, 20(1/2): 34-35, Junho e Dezembro 1990.

1991: 2 trabalhos

GOMES, J.M.; COUTO, L.; BORGES, R.C.G. e FONSECA, E.P. Efeitos de diferentes substratos na produção de mudas de E. grandis W. Hill ex Maiden, em "Win-Strip". ÁRVORE, Viçosa, 15(1): 35-42, Janeiro a Junho 1991.

REIS, G.G.; REIS, M.G.F.; BERNARDO, A.L.; MAESTRI, M.; REGAZZI, A.J.; GARCIA, N.C.P. Efeito do tempo de estocagem de mudas de Eucalyptus produzidas em tubetes sobre a produção de biomassa após o transplantio. ÁRVORE, Viçosa, 15(2): 103-111, Julho a Dezembro 1991.

1992: 1 trabalho 
CARNEIRO, J.G.A. e BRITO, M.A.R. Nova metodologia para produção mecanizada de mudas de P. taeda $\mathrm{L}$. em recipientes com raizes laterais podadas. FLORESTA, Curitiba, 22(1/2): 111, Junho e Dezembro 1992.

1993: 3 trabalhos

CAPRONI, A. L. , VIEIRA, J. D. e DAVIDAE, A. C. (1993). "Efeitos da salinidades e substratos na emergência de plântulas e produção de mudas de $E$. grandis e $E$. citriodora." In: Congresso Florestal Brasileiro, 7. , Paraná, Setembro, 1993, p. 280-282.

CAPRONI, A. L. ; VIEIRA, J. D. e DAVIDE, A. C. (1993). "Germinação de sementes de E. grandis Hill ex maiden e $E$. citriodora Hook, em dois tamanhos, submetidas a diferentes potenciais osmóticos." In: Congresso Florestal Brasileiro, 7. , Paraná, Setembro, 1993, p. 288-291.

MATTEI, V. L. (1993). "Semeadura direta - uma alternativa para implantação de povoamentos de $P$. taeda L. . "In: Congresso Florestal Brasileiro, 7. , Paraná, Setembro, 1993, p. 306-308.

1994: 2 trabalhos

ALVARENGA, R.C.; BARROS, N.F.; DANTAS, C.E.S. e LOBÃO, D.E.V.P. Efeitos do conteúdo de água no solo e da poda de raízes sobre o crescimento de muda de eucalipto. ÁRVORE, Viçosa, 18(2): 107-114, Maio a Agosto 1994.

LIMA, M.C.; PAULA JÚNIOR, T.J. e ZAMBOLIM, L. Efeito de fungos micorrízicos vesículoarbusculares no crescimento de Eucalyptus grandis, em condições de campo. ÁRVORE, Viçosa, 18(2): 169-178, Maio a Agosto 1994.

3) Manejo

3.1) Teste em Solos

1953: 2 trabalhos

PERSE, F.F. (1953) "O Reflorestamento sob o Aspecto Técnico Florestal." In: Congresso Florestal Brasileiro, 1., p. 75, Curitiba, Paraná, 13 a 19 de Setembro, 1953.

VASCONCELLOS, P.W.C. (1953 a) "E. citriodora Hook, Myrtaceae - Sua Acomodação a Solo Xitoso de Certa Profundidade." In: Congresso Florestal Brasileiro, 1., p. 201, Curitiba, Paraná, 13 a 19 de Setembro, 1953.

1978: 1 trabalho

SIMÕES, J.W.; POGGIANI, F.; BALLONI, E.A.; RORIZ, M.S.; LEITE, J.C.C. e VIDIGAL, R.M. Adaptabilidade de espécies florestais de rápido crescimento em solo alterado pela exploração do xisto. IPEF, Piracicaba, (16): 1-12, Junho 1978.

1986: 2 trabalhos 
FRANÇA, F. S. ; MACEDO, P. R. e FERREIRA, M. C. (1986). "Arquitetura de Sistema Radicular de E. saligna em diferentes condições de sítio e suas interações com as características do solo." In: Congresso Florestal Brasileiro, 5. Pernambuco, Novembro, 1986, p. 65.

KREJCI, L.C; MARTINS, L.G.C. e LOURENÇO, P.Y. (1986) "Desenvolvimento do Sistema Radicular de Eucalyptus spp sob diferentes condições de Solo." In: Congresso Florestal Brasileiro, 5., p. 70, Olinda, Pernambuco, 23 a 28 de Novembro, 1986.

\section{7: 1 trabalho}

CAMPOS, J.C.C. e RIBEIRO, J.C. Efeito da qualidade de local na rotação técnica de eucalipto. ÁRVORE, Viçosa, 11(2): 146-157, Julho a Dezembro 1987.

\section{8: 1 trabalho}

GONÇALVES, J.L.M. Interpretação de levantamento de solo para fins silviculturais. IPEF, Piracicaba, (39): 65-72, Agosto de 1988.

1990: 2 trabalhos

GARICOITIS, L.S.L. Estudo Nutricional e fatores do solo limitantes do crescimento do $P$. taeda L. em Telêmaco Borba (PR). FLORESTA, Curitiba, 20(1/2): 108, Junho e Dezembro 1990.

GONÇALVES, J.L.M.; DEMATTÊ, J.L.I. e COUTO, H.T.Z. Relações entre produtividade de sítios florestais de E.grandis e E. saligna com as propriedades de alguns solos de textura arenosa e médias no Estado de São Paulo. IPEF, Piracicaba, (43/44): 24-39, 1990.

1992: 1 trabalho

TREVISAN, E. Classificação e Caracterização de horizontes orgânicos sob povoamentos de $P$. taeda L., na região de Ponta Grossa, PR. FLORESTA, Curitiba, 21 (1/2): 91-92, Junho e Dezembro 1992.

\section{2) Consorciação}

1953: 1 trabalho

VASCONCELLOS, P.W.C. (1953 b) "Saguaragi - Colubrina Rufa, Reiss. Família Rhamnaceae, Consorciação com E. tereticornis e E. rostrata." In: Congresso Florestal Brasileiro, 1., p. 195, Curitiba, Paraná, 13 a 19 de Setembro, 1953.

1973: 1 trabalho

KON, I. Crescimento de Cryptomeria japonica (F.f.) Don. em plantio consorciado com Pinus elliottii Eng. var. elliottii, na Fazenda Arraial. FLORESTA, Curitiba, 4(2): 30-33, 1973.

1983: 2 trabalhos

NOVAES, R. F. F. e POGGIANI, F. (1983). "Efeito da Consorciação entre Pinus caribaea var. hondurensis e Liquidambar styraciflua L., sobre a ciclagem de Nutrientes em Florestas 
Implantadas." In: Congresso Florestal Brasileiro, 4. Minas Gerais, Jan.-Fev., 1983, p. 400403.

NOVAIS, R.F.F. e POGGIANI, F. Deposição de folhas e nutrientes em plantas florestais puras e consorciadas de Pinus e Liquidamba. IPEF, Piracicaba, (23): 57-60, Abril 1983.

1988: 2 trabalhos

JESUS, R.M.; DIAS, G.N.B. e CARDOSO, E.M. Eucalyptus/Leucaena Mixture experiment -Growth and yield. IPEF, Piracicaba, (39): 41-44, Agosto de 1988.

JESUS, R.M.; ROSSMANN, N.C. e BROVARD, J.S. Eucalyptus/Leucaena Mixture experiment- Wood properties. IPEF, Piracicaba, (39): 49-52, Agosto de 1988.

1990: 2 trabalhos

COUTO, L. ; PASSOS, C. A. M. ; GOMES, J. M. e CAPITANI, L. R. (1990). "Consorciação de $E$. grandis W. Hill ex Maiden com cultura agrícola anual no Vale do Rio Doce, Minas Gerais." In: Congresso Florestal Brasileiro, 6. , São Paulo, Setembro, 1990, p. 256-259.

SANTOS, F. L. C. e COUTO, L. (1990). "Comportamento de Eucalipto e forrageiras em plantio consorciado na região do cerrado." In: Congresso Florestal Brasileiro, 6., São Paulo, Setembro, 1990, p. 395-402.

1993: 5 trabalhos

DRUMOND, M. A. e POGGIANI, F. (1993). "Distribuição de biomassa e dos nutrientes em plantações puras e consorciadas de Liquidambar styraciflua e Pinus caribaea hondurensis." In: Congresso Florestal Brasileiro, 7., Paraná, Setembro, 1993, p. 234-239.

GARCIA, N. C. P. ; SALGADO, L. T. ; REIS, G. G. e FREITAS, R. T. F. (1993). "Consorciação do eucalipto com gramínea forrageira na Zona da Mata de Minas Gerais, com aplicação de gesso." In: Congresso Florestal Brasileiro, 7. , Paraná, Setembro, 1993, p. 273-275.

JESUS, R. M. ; GARCIA, A. ; DÁRIO, F. R. e DIAZ, M. D. P. (1993). "Eficiência da Leucaena leucocephala (Lam) de wit var. K72 em E. urophylla s. t. Blake." In: Congresso Florestal Brasileiro, 7. , Paraná, Setembro, 1993, p. 283-284.

PASSOS, C. A. M. ; COUTO, L. e FERNANDES, E. N. (1993). "Comportamento inicial de E. grandis W. Hill ex Maiden consorciado com milho (Zea mays) e feijão (Phaseolus vulgaris) no Vale do Rio Doce, Minas Gerais." In: Congresso Florestal Brasileiro, 7. , Paraná, Setembro, 1993, p. 269-270.

RIBASKI, J. ; OLIVEIRA, M. C. e CRUZ, S. C. (1993). "Avaliação de um sistema silvopastoril em região semi-árida, envolvendo a consorciação de eucalipto com pastagens." In: Congresso Florestal Brasileiro, 7. , Paraná, Setembro, 1993, p. 267-268.

\section{3) Espaçamento}

1953: 1 trabalho 
PERSE, F.F. (1953) "O Reflorestamento sob o Aspecto Técnico Florestal." In: Congresso Florestal Brasileiro, 1., p. 75, Curitiba, Paraná, 13 a 19 de Setembro, 1953.

\section{0: 1 trabalho}

COELHO, A.S.R.; MELLO, H.A. e SIMÕES, J.W. Compertamento de espécies de eucaliptos face ao espaçamento. IPEF, Piracicaba, (1): 29-55, Janeiro a Junho 1970.

\section{1: 2 trabalhos}

BERENHAUSER, H. Espaçamento nos plantios de $P$. elliottii e taeda. FLORESTA, Curitiba, $\underline{3}$ (2): 21 27, Novembro 1971.

MELLO, H.A.; SIMÕES, J.W.; MASCARENHAS SOBRINHO, J. e COUTO, H.T.Z. Influência do espaçamento na produção de madeira de eucalipto em solo de cerrado. IPEF, Piracicaba, (213): 3-30, 1971.

\section{6: 1 trabalho}

MELLO, H.A.; SIMÕES, J.W.; FERREIRA, C.A. e BRASIL, U.M. Influência do espaçamento e da idade de corte na produção de madeira de eucalipto em solos de cerrado. IPEF, Piracicaba, (13): 143-162, Dezembro 1976.

1977: 1 trabalho

COUTO, L.; BRANDI, R.M.; CONDÉ, A.R. e PAULA NETO, F. Influência do espaçamento no crescimento do $\mathrm{E}$. uroplylla, de origem híbrida, cultivado na região de Coronel Fabriciano, Minas Gerais. ÁRVORE, Viçosa, 1 (2): 57-71, Julho a Dezembro 1977.

1983: 6 trabalhos

BALLONI, E.A.; GARCIA, P.V. e CONÇALVES, J.C. (1983) "Efeitos do Espaçamento e Adubação sobre a Recuperação de Plantio de $E$. grandis danificadas pela Geada." In: Congresso Florestal Brasileiro, 4., p. 172, Minas Gerais, Jan-Fev, 1983.

BALLONI, E.A.; GARCIA, P.V. e CONÇALVES, J.C. (1983) "Efeitos do Espaçamento e Adubação sobre a Recuperação de Plantio de $E$. grandis danificadas pela Geada." In: Congresso Florestal Brasileiro, 4., p. 172, Minas Gerais, Jan-Fev, 1983.

MONTEIRO, R. F. R. e CORDEIRO, J. A. (1983). "Ensaio Conjugado de Espaçamentos e de Métodos de Desbaste em Pinus elliottii Engelm." In: Congresso Florestal Brasileiro, 4. Minas Gerais, Jan.-Fev. , 1983, p. 361-363.

MONTEIRO, R.F.R. e CORDEIRO, J.A. (1983) "Ensaio de Competição entre Espaçamentos em Pinus taeda." In: Congresso Florestal Brasileiro, 4.,p. 357, Minas Gerais, Jan.-Fev., 1983.

PEREIRA, A.R.; MORAES, E.J. e NASCIMENTO, M.B.F (1983 b) "Implantação de Florestas de Ciclos - Curtos sob Novos Modelos de Espaçamentos", in Congresso Florestal Brasileiro, 4., p. 429, Minas Gerais, Jan.-Fev., 1983. 
REZENDE, J.L.P.; PEREIRA, A.R. e OLIVEIRA, A.D. Espaçamento ótimo para a produção de madeira. ÁRVORE, Viçosa, 7(1): 30-43, Janeiro a Junho 1983.

1986: 2trabalhos

FRANÇA, F. S. e FREITAS, A. J. P. (1986). "Estudo de Espaçamentos com E. dunnii." In: Congresso Florestal Brasileiro, 5. Pernambuco, Novembro, 1986, p. 65.

FREITAS, A. J. P. ; GONZAGA, J. V. ; FRANÇA, F. W. S. e RECH, B. (1986). "Influência do Espaçamento na Produção de Madeira de E. saligna. "In: Congresso Florestal Brasileiro, 5. Pernambuco, Novembro, 1986, p. 64.

1987: 1 trabalho

VITAL, B.R. e LUCIA, R.M.D. Efeito do espaçamento na produção em peso e na qualidade da madeira de E. grandis e E. urophylla aos 52 meses de idade. ÁRVORE, Viçosa, 11(2): 132-145, Julho a Dezembro 1987.

1990: 1trabalho

CAMPOS, J.C.C.; LEITE, H.G.; SOUZA, R.N. e VITAL, B.R. Relações entre espaçamento, volume e peso de madeira em plantações de eucalipto. ÁRVORE, Viçosa, 14(2): 119-133, Julho a Dezembro 1990.

\section{4) Brotação}

1972: 2 trabalhos

SIMÕES, J.W.; PEREIRA, R.A.G.; TANAKA, O.K. e POMPEU, R.M. Efeitos da ferramenta de corte sobre a regeneração do eucalipto. $\underline{\text { IPEF}}$, Piracicaba, (4): 3-10, 1972.

SIMÕES, J.W.; KROGH, H.J.O; CIERO NETO, A.D. e POMPEU, R.M. Influência do vigor das árvores sobre a brotação das touças de eucalipto. IPEF, Piracicaba, (5): 51-56, 1972.

1973: 2 trabalhos

BAENA, E.S. (1973) "Nota Prévia Sobre a Viabilidade Econômica da Eliminação Química de Brotas de Eucalipto." In: Congresso Florestal Brasileiro, 2., p. 135, Curitiba, Paraná, 17 a 21 Set., 1973.

COUTO, H.T.Z; MELLO, H.A.; SIMÕES, J,W, e VENCOVSKY, R. Condução de brotação de $E$. saligna Smith. IPEF, Piracicaba, (7): 115-123, 1973.

1977: 1 trabalho

COUTO, H.T.Z. Tabelas de volume para brotação de touças de E. saligna Sm. IPEF, Piracicaba, (15): 117-121, Dezembro 1977. 
SIMÕES, J. W. e SILVA, A. P . (1978). "Condução de Touças de Eucalyptus ." In:: Congresso Florestal Brasileiro, 3. Amazonas, Dezembro, 1978, p. 87-89.

1982: 1 trabalho

PAULA NETO, F.; PEREIRA, A.R.; BRANDI, R.M. e PAIVA, H.N. Fatores que influem no desenvolvimento de brotações de eucaliptos. ÁRVORE, Viçosa, 6(2): 133-139, Julho a Dezembro 1982.

1983: 3 trabalhos

NASCIMENTO FILHO, M.B.; MAGALHÃES, J.G.R.; FERNANDES, J.C. e PEREIRA, A.R. (1983 b) "Influência da Altura de Corte sobre a Sobrevivência das Touças de Eucalyptus." In: Congresso Florestal Brasileiro, 4., p. 389, Minas Gerais, Jan.-Fev., 1983.

PAIVA, H.N.; PAULA NETO, F.; BRANDI, R.M. e VALE, A.B. Influência da idades de corte e de desbrota e do número de brota sobre o desenvolvimento da brotação de cepas de Eucalyptua spp. ÁRVORE, Viçosa, 7(1): 1-9, Janeiro a Junho 1983.

POGGIANI, F.; REZENDE, G.C. e SUITER FILHO, W. Efeitos do fogo na brotação e crescimento de E. grandis após o corte raso e alterações nas propriedades do solo. IPEF, Piracicaba, (24): 33-42, Agosto 1983.

1985: 1 trabalho

SIMÕES, J.W. e COTO, N.A.S. Efeito do número de brotas e da fertilização mineral sobre o crescimento de brotação de E. saligna Smith em segunda rotação. IPEF, Piracicaba, (31): 23-32, Dezembro 1985.

1986: 3 trabalhos

REIS, G.G. e HALL, A.E. Resposta de brotações de E. camaldulensis Dehn. submetidas a diferentes níveis de deficiência hídrica. ÁRVORE, Viçosa, 10(1): 16-26, Janeiro a Junho 1986.

REIS, M.G.F. e KIMMINS, J. (1986) "Importância do Sistema Radicular no Crescimento Inicial de Brotos de Eucalyptus spp." In: Congresso Florestal Brasileiro, 5., p. 136, Olinda, Pernambuco, 23 a 28 de novembro, 1986.

REIS, M.G.F. e KIMMINS, J.P. Importância do Sistema radicular no crescimento inicial de brotos de Eucalyptus spp. ÁRVORE, Viçosa, 10(2): 196-201, Julho a Dezembro 1986.

1990: 1 trabalho

BRASSIOLO, M.M. Avaliação da regeneração natural de $P$. elliotii var. elliottii na Floresta Nacional de Capão Bonito. FLORESTA, Curitiba, 20(1/2): 64-65, Junho e Dezembro 1990.

1992: 1 trabalho 
RIBEIRO, F.A.; COUTO, L.; GOMES, J.M. e BORGES, R.C.G. Influência da anelagem e reguladores de crescimento na indução da brotação de cepas de E. grandis W. Hill ex Maiden. ÁRVORE, Viçosa, 16(3): 247-254, Janeiro a Abril 1992.

\section{5) Desbaste}

1973: 2 trabalhos

CARNEIRO, J.G.A. Desbastes florestais. FLORESTA, Curitiba, 4(1): 45-56, 1973.

FISHIWICK, R.W. (1973) "Estudos de Espaçamento e desbaste em Plantações Brasileiras." In: Congresso Florestal Brasileiro, 2., p. 202, Curitiba, Paraná, 17 a 21 de Setembro, 1973.

1974: 1 trabalho

FISHWICK, R. Pesquisa de intensidade de desbaste. FLORESTA, Curitiba, $\underline{5}(1): 35-45,1974$.

1981: 1 trabalho

CAMPOS, J.C.C. e TURNBULL, K.J. Um sistema para estimar produção por classe de diâmetro e sua aplicação na interpretação de efeitos de desbaste. ÁRVORE, Viçosa, $\underline{5}(1)$ : 1-16, Janeiro a Junho 1981.

\section{2: 1 trabalho}

ABREU, P.S.C. Metodologia para a regulação da produção dos desbastes FLORESTA, Curitiba, 13(1): 44, Junho 1982.

1983: 3 trabalhos

BERTOLOTI, G.; SIMÕES, J.W.; NICOLIELO, N. e GARCIA, J.B. Efeitos de diferentes métodos e intensidades de desbaste na produtividades de $P$. caribaea var hondurensis Barr. et Golf. IPEF, Piracicaba, (24): 47,54, Agosto 1983.

FERNANDES, P.S. Condições de eucaliptais com alternativas de uso (Resultados Preliminares). IPEF, Piracicaba, (24): 55-56, Agosto 1983.

MONTEIRO, R. F. R. e CORDEIRO, J. A. (1983). "Ensaio Conjugado de Espaçamentos e de Métodos de Desbaste em Pinus elliottii Engelm." In: Congresso Florestal Brasileiro, 4. Minas Gerais, Jan.-Fev., 1983, p. 361-363.

1984: 1 trabalho

PEREIRA, A.R. e VALE, A.B. Desbastes intermediários em florestas de alta rotatividade visando a produção de carvão vegetal. IPEF, Piracicaba, (26): 9-11, Abril 1984.

\section{6) Outros}

1970: 3 trabalhos 
BERENHAUSER, H. Importância de poda em Pinus spp para a produção de madeira de melhor qualidade. FLORESTA, Curitiba, 2(3): 33-36, Dezembro 1970.

GOMES, J.M.; FERREIRA, M.G.M.; BRANDI, R.M. e PAULA NETO, F. Influência do sombreamento no desenvolvimento de $E$. grandis W. Hill ex Maiden. ÁRVORE, Viçosa, 2(1): 8-75, Janeiro a Julho 1970.

SCHMIDLIN, D. Viveiro - Um bom sistema de repicagem para Pinus. FLORESTA, Curitiba, 22(3): 2526, Dezembro 1970.

1973: 1 trabalho

SCHMIDLIN, D. (1973) "Importância da Poda na Qualidade da Madeira." In: Congresso Florestal Brasileiro, 2., p. 186, Curitiba, Paraná, 17 a 21 de Setembro, 1973.

1978: 2 trabalhos

FERREIRA, C. A. e TIMONI, J. L. (1978). "Contribuição ao Estudo da Determinação da Época de Corte em Povoamentos de Eucaliptus spp (E. urophylla, E. grandis, E. saligna)." In: Congresso Florestal Brasileiro, 3. Amazonas, Dezembro, 1978, p. 85-86.

MAGALHÃES, J. G. R. ; NASCIMENTO FILHO, M. B. ; MORAES, E. J. e FERNANDES, J. C. (1978). "Plantio de E. camaldulensis e E. grandis com irrigação na cova em solos de Cerrado." In: Congresso Florestal Brasileiro, 3. Amazonas, Dezembro, 1978, p. 315-320.

1979: 1 trabalho

FREITAS, M.; SILVA, A.P.; GUTIERREZ NETO, F. e CANEVA, R.A. O interplantio como alternativa para rotações sucessivas em Eucalyptus. IPEF, Piracicaba, (19): 1-16, Dezembro 1979.

1982: 1 trabalho

NOGUEIRA, A.C. Estudo de rendimento de poda em povoamento de $P$. taeda L. FLORESTA, Curitiba, 13(2): 24-25, Dezembro 1982.

1983: 4 trabalhos

BORSSATO, I; RECH, B. e FREITAS, A.J.P. (1983) "Efeito do Preparo do Solo Sobre o Desenvolvimento de E. saligna Smith." In: Congresso Florestal Brasileiro, 4., p. 192, Minas Gerais, Jan.-Fev., 1983.

FREITAS, A.L.; NOVELLI, A.B.; MAGALHÃES, J.G.R. e ULHOA, M.A. (1983) "Comportamento de Espécies de Eucaliptus em Interplantio." In: Congresso Florestal Brasileiro, 4., p. 289, Minas Gerais, Jan.-Fev., 1983.

NASCIMENTO FILHO, M.B.; HENRIQUES, E.P.; ROCHA, D.; MAGALHÃES, J.G.R. e FERNANDES, J.C. (1983 a) "Efeito do Cultivo no Desenvolvimento do E. saligna, na região de Itamarandiba, MG "in Congresso Florestal Brasileiro, 4., p. 387, Minas Gerais, Jan.-Fev., 1983. 
ROCHA, D.; NASCIMENTO, M.B.F"; MAGALHÃES, J.G.R. e FERNANDES, J.C. (1983 a) "Efeitos dos Sistemas de Preparo do Solo no Crescimento de E. grandis na Região de Capelinha, MG." In: Congresso Florestal Brasileiro, 4., p. 464, Minas Gerais, Jan.-Fev., 1983.

1984: 3 trabalhos

FERRAZ, E.S.B. e COUTINHO, A.R. Efeitos da geada na madeira de E. saligna. IPEF, Piracicaba, (28): 57-62, Dezembro 1984.

MARTINI, S.L.; BORSSATO, I. e SIMÕES, J.W. Estudo da viabilidade do interplantio em povoamento de E. grandis em segunda rotação. IPEF, Piracicaba, (28): 45-48, Dezembro 1984.

TROVATI, L.R. e FERRAZ, E.S.B. Influência da precipitação e da temperatura na densidade dos anéis de crescimento de Pinus oocarpa. IPEF, Piracicaba, (26): 31-36, Abril, 1984.

1986: 3 trabalhos

BARROS, N.F.; NOVAIS, R.F.; CARMO, D.N. e NEVES, J.C.L. Classificação nutricional de sítios florestais - descrição de uma metodologia. ÁRVORE, Viçosa, 10(1): 112-120, Janeiro a Junho 1986.

MENDES, C. J. e MOREIRA, P. M. (1986). "Efeito da Poda Aérea na Produção de Sementes em Pomar de P. taeda L." In: Congresso Florestal Brasileiro, 5. Pernambuco, Novembro, 1986, p. 64.

FINGER, C. A. G. ; GONZAGA, J. V. e FREITAS, A. J. P. (1986). "Estudo da Viabilidade Técnica do Interplantio de Florestas de Eucalyptus em $2^{\circ}$ Rotação." In: Congresso Florestal Brasileiro, 5. Pernambuco, Novembro, 1986, p. 65.

1987: 1 trabalho

MILANO, M.S.; BRASSIOLO, M.M. e SOARES, R.V. Zoneamento ecológico experimental do Estado do Paraná segundo o sistema de zonas de Holdridge. FLORESTA, Curitiba, 17(1/2): 65-72, Julho e Dezembro 1987.

1989: 2 trabalhos

FIGUEIREDO FILHO, A.; SCHREINER, C.A.; PINHEIRO, C.N.F. e MORAES, M. Efeitos da resinagem no crescimento de $P$. elliottii var. elliottii. FLORESTA, Curitiba, 19(1/2): 5054, Junho e Dezembro 1989.

REIS, G.G.; REIS, M.G.F.; MAESTRI, M.; XAVIER, A. e OLIVEIRA, L.M. Crescimento de E. camaldulensis, E. grandis e E. cloeziana sob diferentes níveis de restrição radicular. ÁRVORE, Viçosa, 13(1): 1-18, Janeiro a Junho 1989.

1991: 2 trabalhos

FIGUEIREDO FILHO, A. Influência de resinagem no crescimento de $P$. elliottis Engelm. var. elliottii e sua avaliação econômica. FLORESTA, Curitiba, 21(1/2): 86-87, Junho e Dezembro 1991. 
REIS, G.G.; REIS, M.G.F.; BERNARDO, A.L. e MAESTRI, M. Efeito da poda sobre a arquitetura do sistema radicular e o crescimento de mudas de $E$. grandis e $E$. citriodora produzida em tubete. ÁRVORE, Viçosa, 15(1): 43-54, Janeiro a junho 1991.

1992: 1 trabalho

MARTINS, S.L.; REIS, M.G.F.; SOUZA, A.L.; ASPIAZÚ, C.; REIS, G.G. Classificação ecológica do Estado do Espírito Santo baseada em condições climáticas. ÁRVORE, Viçosa, 16(3): 272286, Setembro a Dezembro 1992.

1994: 2 trabalhos

FREITAS, S. e BERTI FILHO, E. Efeito da desfolha parcial e total na produção de biomassa de $E$. grandis Maiden (myrtaceae) IPEF, Piracicaba, (47): 29-35, Maio 1994.

FREITAS, S. e BERTI FILHO, E. Efeito do desfolhamento no crescimento de E. grandis Maiden (myrtaceae) IPEF, Piracicaba, (47): 36-43, Maio 1994.

4) Controle de Pragas e Doenças

4.1) Novos Produtos

1953: 1 trabalho

GUIMARÃES, R.F.; KRUG, H.P. e PINHEIRO, J.V. (1953) "Tratamentos de Sementeiras de Eucalipto e seu Efeito sobre o Desenvolvimento das Mudas." In: Congresso Florestal Brasileiro, 1., p. 129, Curitiba, Paraná, Set. 1953.

1969: 1 trabalho

BICQUELOT, A. Ataque de Enselasia enverns nos eucaliptais da Cia Siderúrgica Belgo-Mineira. FLORESTA, Curitiba, 1(1): 23-35, Junho 1969.

1971: 1 trabalho

KRÜGNER, T.L. e CARVALHO, P.C.T. Ensaios em condições de casa vegetação para controle químico de "Dumping-Off" em E. saligna Smith. IPEF, Piracicaba, (2/3): 97-1 13, 1971.

1972: 1 trabalho

KRÜGNER, T.L. e CARVALHO, P.C.T. Ensaios de condições de campo para o controle químico de "Dumping-Off" em E. saligna Smith. IPEF, Piracicaba, (4): 39-59, 1972.

1973: 2 trabalhos

GRECO, A.R. e ROBBS (1973) "Seca da Folhagem de Pinheiros (Pinus spp) Enviveirados Incitados por Rhyzoctonia solani Kuhn." In: Congresso Florestal Brasileiro, 2., p. 163, Curitiba, Paraná, Setembro de 1973 
GRODZKI, R.M. Gryllus assimilis: danos causados e métodos e combate. FLORESTA, Curitiba, 4(2): 34-37, 1973.

1974: 1 trabalho

BAZAN, F.AC. e MINAMI, K. Resultados preliminares sobre testes de herbicidas em eucalipto. IPEF, Piracicaba, (8): 47, Outubro 1974.

1975: 1 trabalho

CARNEIRO, J.G.A. e ROCHA, F. Efeitos de alguns produtos em ação pós-emergente em mudas de $P$. taeda, L. FLORESTA, Curitiba, $6(1): 43-48,1975$.

1976: 1 trabalho

BRASIL, U.M.; FERNANDES, P.S.; SIMÕES, J.W. e FERREIRA, J.E.F. Emprego de herbicidas na implantação de povoamentos de E. saligna Sm. IPEF, Piracicaba, (13): 213-134, Dezembro 1976.

1977: 2 trabalhos

BRANDI, R.M.; COUTO, L.; SILVA, J.F. e MYASAKI, J.M. Tolerância de diversas espécies de eucalipto a alguns herbicidas. ÁRVORE, Viçosa, 1(2): 149-153, Julho a Dezembro 1977.

ZANÚNCIO, J.C.; SUPLICY FILHO, N. VILELA, E.F. E VIEIRA, M. Controle Quimico e Microbiológico de $P$. involuta e de $S$. violascens, no Município de Curvelo, Estado de Minas Gerais. ÁRVORE, Viçosa, 1 (2): 107-120, Julho a Dezembro 1977.

1978: 2 trabalhos

CORRADINE, L. ; AGUIAR, I. B. ; BARRETO, M. ; ARANTES, A.G. B. e CARRARA, M. A. (1978). "Controle Químico do Damping-Off em Sementeiras de E. grandis Hill ex Maiden." In: Congresso Florestal Brasileiro, 3. Amazonas, Dezembro, 1978, p. 101-103.

FARIA, A. B. ; REZENDE, G. C. ; MENDES FILHO, J. M. A. e SUITER FILHO, W. (1978). "Uso de Aldrin em Mudas de Eucalyptus." In: Congresso Florestal Brasileiro, 3. Amazonas, Dezembro, 1978, p. 365-366. *

1979: 3 trabalhos

ALFENAS, A.C. e FERREIRA, F.A. A mancha de folha de Eucalipto no Brasil causada por três espécies de Culindrocladium - Uma revisão da descrição da doença. ÁRVORE, Viçosa, $\underline{3}$ (1): 47-56, Janeiro a Julho 1979.

MIYASAKI, J.M.; PEREIRA, A.R.; SILVA, J.F. e FREITAS, A.L. Manutenção de aceiros em povoamentos florestais pelo uso de herbicidas. ÁRVORE, Viçosa, $\underline{3}(2)$ : 172-181, Julho a Dezembro 1979. 
ZANÚNCIO, J.C.; SUPLICY FILHO, N.; VILELA, E.F. e FARIA, A.B. Controle químico e microbiológico de Euselasia apiscion (Lepdoptera: Riodinidae) em condições de aboratório de Campo. ÁRVORE, Viçosa, $\underline{3}$ (1): 75-87, Janeiro a Julho 1979.

\section{1: 1 trabalho}

ANJOS, N.; LUDWIG, A.; SANTOS, G.P. e MOREIRA, J.F. Eficiência de três produtos químicos e de um processo mecânico do controle de lagartas-posca em mudas de $E$. grandis Hill ex

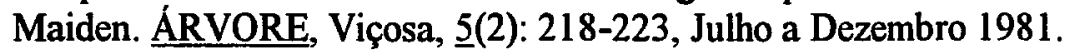

\section{3: 1 trabalho}

CARVALHO, C.M.; VEIGA, R.A.A e COUTINHO, C.J. (1983) "Efeitos do Thiran no Comportamento de Germinação de diferentes lotes de sementes de $E$. saligna Smith e seu Relacionamento com a Perda de Vigor Natural." In: Congresso Florestal Brasileiro, 4., p. 258, Minas Gerais, Jan.-Fev., 1983.

1992: 2 trabalhos

LUCIA, T.M.C.D.; CAMERON, R.S.; VILELA, E.F. e BENTO, J.M.S. Aceitação de iscas granuladas com Sulfluramida, um novo princípio ativo, por formigas cortadeiras, no campo. ÁRVORE, Viçosa, 16(2): 218-223, Maio a Agosto 1992.

ZANÜNCIO, J.C.; COUTO, L.; SANTOS, G.P. e ZANÜNCIO, T.V. Eficiência da isca granulada Mirex-5, à base de Sulfluramid, no controle da formiga cortadeira Atta laevigata (F. Smith 1052) (Hymenoptera: Formiciae). ÁRVORE, Viçosa, 16(3): 357-361, Setembro a ezembro 1992.

1993: 1 trabalho

ALFENAS, A.C.; MAFFIA, L.A.; MACABEU, A.J. e SARTóRIO, R.C. Eficiência de Triadimenol, Oxicarboxim e Diniconazole para o controle da ferrugem (Puccinia psidü) em brotações de E. cloeziana, em condições de campo. ÁRVORE, Viçosa, 17(2): 247-263, Maio a Agosto 1993.

\section{2) Novas Dosagens}

1973: 1 trabalho

GRODZKI, R.M. (1973) "Danos Causados pelo Gryllus assimilis Fabr., 1775 no E. saligna e Competição de Inseticidas no Combate a esse Grilo." In: Congresso Florestal Brasileiro, 2., p. 154, Curitiba, Paraná, 17 a 21 de Setembro, 1973.

1983: 3 trabalhos

CARVAlHo, C. M. ; VEIGA, R. A. A. e COUTINHO, C. J. (1983). "Efeitos de Dosagens e Princípios Ativos de Fungicidas na Germinação de Sementes de E. saligna Smith." In: Congresso Florestal Brasileiro, 4. Minas Gerais, Jan.-Fev., 1983, p. 252-257. 
MORAES, T.S.A.; REZENDE, G.C.; MENDES, C.J. e SUITER, W.Fo (1983 a) "Estudo de Dosagens de Isca Formicida para Sauveiros Jovens", in Congresso Florestal Brasileiro, 4., p.365, Minas Gerais, Jan.-Fev, 1983.

MORAES, T.S.A.; REZENDE, G.C.; MENDES, C.J. e SUITER, W.Fo (1983 b) "Estudo de Contaminação da Isca Formicida pela Termonebulização quando em Uso Simultâneo na mesma Área." In: Congresso Florestal Brasileiro, 4., p. 366, Minas Gerais, Jan.-Fev., 1983.

1986: 1 trabalho

LARANJEIRO, A. J. ; ALVES, J. E. M. ; MARQUES, C. G. e ALMEIDA, A. F. (1986). "Análise das Distribuição de Micro-Porta-Iscas em Áreas de Reforma de Eucalyptus spp., visando o controle de formigas cortadeiras (Atta spp e Acormyrmex spp)." In: Congresso Florestal Brasileiro, 5. Pernambuco, Novembro, 1986, p. 36.

\section{3) Novos Sistemas}

1975: 1 trabalho

MORAES, G.J.; MACEDO, N. e CARVALHO, J.C.B. Ocorrência de Derphiopsis trisignata Walter, 1855 e seu controle com Bacillus thuringiensis Berliner. IPEF, Piracicaba, (11): 43-47, Outubro 1975.

\section{7: 2 trabalhos}

COUTO, L.; ZANUNCIO, J.C.; ALVES, J.E.M.; CAMPINHOS JÚNIOR, E.; SORESINE, L. e VARGAS, J.A. Avaliação da eficiência e custo do controle de Atta sexdens rubropilosa através do sistema termo-nebulizador, na Região de Aracruz, E.S. ÁRVORE, Viçosa, 1 (1): 9-16, Março 1977.

ZANÚNCIO, J.C.; SUPLICY FILHO, N. VILELA, E.F. E VIEIRA, M. Controle Químico e Microbiológico de $P$. involuta e de $S$. violascens, no Município de Curvelo, Estado de Minas Gerais. ÁRVORE, Viçosa, 1 (2): 107-120, Julho a Dezembro 1977.

1978: 3 trabalhos

MORAES, G. W. G. ; BRUN, P. G. ; SOARES, L. A. e RIBEIRO, C. M. (1978). "Estabelecimento de Métodos de Controle Biológico de Lepdópteros Desfoliadores de Eucalipto." In: Congresso Florestal Brasileiro, 3. Amazonas, Dezembro, 1978, p. 389.

SANTOS, G. P. ; GOMES, J. M. ; ZANÚNCIO, J. C. e BRANDI, R. M. (1978). "Controle de Saúvas pelo Sistema de Termonebulização, na Região de Timóteo, MG. "In: Congresso Florestal Brasileiro, 3. Amazonas, Dezembro, 1978, p. 350-351.

ZANÚNCIO, J.C.; SUPLICY FILHO, N.; VILELA, E.F. e FARIA, A.B. Controle químico e microbiológico de Euselasia apiscion (Lepdoptera: Riodinidae) em condições de aboratório de Campo. ÁRVORE, Viçosa, $\underline{3}$ (1): 75-87, Janeiro a Julho 1979.

1979: 1 trabalho 
SANTOS, G.P.; VILELA, E.F. e NOGUEIRA, S.B. Estudo da Bionomia e Controle Microbiológico de Oxydia apidania (Cramer) (Lepdoptera: Glomitridae) desfolhador de eucalipto. ARVORE, Viçosa, $\underline{3}(1)$ : 57-74, Janeiro a Julho 1979.

1980: 1 trabalho

ZANÚNCIO, J.C.; VILELA, E.F. e NOGUEIRA, S.B. Emprego de iscas granuladas e pós secos no controle da Atta laevigata, no municipío de Curvelo, MG. ÁRVORE, Viçosa, 4(2): 221-26, julho a Dezembro 1980.

1981: 1 trabalho

ZANÚNCIO, J.C.; COMINATTO JÚNIOR, J.L.; BEIG, O. e ZANÚNCIO, T.V. Armadilhas luminosas com painel fotovoltaico para monitoramento e supressão populacional de lepdópteros desfolhadores de eucalipto. ÁRVORE, Viçosa, 15(1): 95-102, Janeiro a Junho 1981.

1983: 4 trabalhos

ALMEIDA, A. F. (1983) "O Princípio do Uso de Porta-Iscas no Controle das Formigas Cortadeiras em Florestas Implantadas." In: Congresso Florestal Brasileiro, 4., p. 132, Minas Gerais, JanFev., 1983.

ALMEIDA, A. F. ; ALVES, J. E. M. e MENDES FILHO, J. M. A. (1983). "A Avifauna e o Sub. Bosque como Fatores Auxiliares no Controle Biológico das Saúvas em Florestas Implantadas." In: Congresso Florestal Brasileiro, 4. Minas Gerais, Jan.-Fev. , 1983, p. 145150.

ALVES, J. E. M. e CAMPINHOS JÚNIOR, E. (1983). "Teste para Utilização de Porta-iscas no Combate à Saúva, na Aracruz Florestal." In: Congresso Florestal Brasileiro, 4. Minas Gerais, Jan.-Fev. , 1983, p. 151-155.

FERREIRA, F.A. Ferrugem do eucalipto. ÁRVORE, Viçosa, 7(2): 91-109, Julho a Dezembro 1983.

1984: 1 trabalho

OLIVEIRA, A.C.; FONSECA, E.P.; ANJOS, N.; SANTOS, G.P. e ZANÚNCIO, J.C. Resistência interespecifica de Eucalyptus spp (Myrtaceae) à lagarta desfolhadora Thyrinteina arnobia Stoll, 1782 (Lepidoptera: Geomitridae). ÁRVORE, Viçosa, 8(2): 93-103, Julho a Dezembro 1984 .

1986: 2 trabalhos

BERTI FILHO, E. e KRUGNER, T.L. (1986) "Manejo Integrado de Pragas e Doenças em Povoamentos de Eucalyptus no Brasil." In: Congresso Florestal Brasileiro, 5., p. 41, Olinda, Pernanbuco, 23 a 28 de Novembro, 1986.

IEDE, E. T. (1986). "Controle Integrado: Uma Op̧̧ão ao Combate de Pragas Florestais no Brasil." In: Congresso Florestal Brasileiro, 5. Pernambuco, Novembro, 1986, p. 43.

1988: 2 trabalhos 
ALVES, S.B.; LARANJEIRO, A.J. e ALVES, J.E.M. A vigilância florestal e o estudo de agentes supressores de pragas. IPEF, Piracicaba, (38): 50-51, Abril de 1988.

OHASHI, O.S. e BERTI FILHO, E. Inimigos naturais de Eupseudosomona aberrans schaus, 1905 e $E$. involuta (Sepp, 1852) (Lepdoptera, Arctüdae), pragas de Eucalyptus spp (Myrtaceae). IPEF, Piracicaba, (40): 43-44, Dezembro 1988.

1990: 1 trabalho

GONÇALVES, L.; BUENO, W.H.P. e CARVALHO, C.F. Controle biológico em Eucalyptus spp: 1.Etologia de ninfas e adultos de Podisus negrolimbatus S.Pinola, 1832 e Podisus connexivus Bergroth, 1891 (hemiptera: pentatomidae: asopinae). IPEF, Piracicaba, (43/44): 70-73, 1990.

1992: 2 trabalhos

CARVALHO, A.G. Bioecologia de Silex noctilio F., 1793 (Hymenoptera; Siricidae) em povoamento de $P$. taeda. FLORESTA, Curitiba, 21(1/2): 82-83, Junho e Dezembro 1992.

DIODATO, M.A. Ocorrência natural, ensaio de laboratório e de campo de B. bassiana (Bals.) em Sirex noctilio F. , praga de $P$. taeda L. FLORESTA, Curitiba, 21(1/2): 84, Junho e Dezembro 1992.

1993: 2 trabalhos

OLIVEIRA, E. P. ; LUZ, H. F. ; MELZER, J. F. e BERTI FILHO, E. (1993). "Controle biológico aéreo da lagarta parda ( Thyrinteina arnobia) em eucalipto, no Sudoeste Paulista." In: Congresso Florestal Brasileiro, 7., Paraná, Setembro, 1993, p. 182-185.

SANTOS, H.R. (1993) "Controle Biológico ou Proteção Convencional das Florestas?." In: Congresso Florestal Panamericano/Congresso Florestal Brasileiro, 1./7., p.150, Curitiba, Paraná, 19 a 24 de Setembro, 1993.

5) Adubação

5.1) Novos Produtos

1953: 1 trabalho

THIEMANN, J.E. (1953) "A Degradação Microbiológica de Resíduos Vegetais." In: Congresso Florestal Brasileiro, 1., p. 231, Curitiba, Paraná, 13 a 19 de Setembro, 1953.

1970: 1 trabalho

SIMÕS, J.S.; MASCARENHAS SOBRINHO, J.; MELLO, H.A. e COUTO, H.T.Z. A adubação acelera o desenvolvimento inicial de plantações de $P$. caribaea var. Bahamensis. IPEF, Piracicaba, (1): 59-80, Janeiro a Junho 1970. 
SIMÕES, J.W.; MELLO, H.A.; LEITE, N.B. e CIERO NETTO, A. Resultados preliminares sobre a fertilização fosfatada no plantio de eucalipto (Nota Prévia). IPEF, Piracicaba, (5): 61-63, 1972.

1975: 1 trabalho

MUNIZ, P.J.C.; BALDANZI, G. e PÉLliCo NETO, S. Ensaio de adubação em Pinus elliottii e Pinus taeda no sul do Brasil. FLORESTA, Curitiba, 6(1): 5-13, 1975.

1977: 2 trabalhos

BARROS, N.F.; BRANDI, R.M.; COUTO, L. e FONSECA, S.M. Aplicação de fertilizantes minerais na formação de mudas de $E$. grandis Maiden ex Hook através da água da irrigação. ÁRVORE, Viçosa, 1 (1): 17-25, Março 1977.

BRAGA, J.M.; COUTO, L.; NEVES, M.J.B. e BRANDI, R.M. Comportamento de Mudas de Eucalyptus spp. em viveiro, em relação à aplicação de N, P, K e diferentes fontes de fósforo. ÁRVORE, Viçosa, 1 (2): 135-148, Julho a Dezembro 1977.

1980: 1 trabalho

ZOETTL, H.W. Possibilidades de utilização da casca de essências florestais para o melhoramento do solo. FLORESTA, Curitiba, $\underline{11}$ (2): 45-51, Dezembro 1980.

1981: 2 trabalhos

SANTOS FILHO, A. e TOURINHO, L.C.N. Caracterizações analíticas de lodo e interpretações para fins agrícola e florestais. FLORESTA, Curitiba, 12(2): 28-35, Dezembro 1981.

SANTOS FILHO, A. e TOURINHO, L.C.N. Caracterizações analíticas de lodo e interpretações para fins agrícola e florestais I- propriedades fisicas e químicas. FLORESTA, Curitiba, 12(1): 44-48, Junho 1981.

1982: 2 trabalhos

BARROS, N.F.; PEREIRA, A.R. e BORBA, A.M. Liberação de Nutrientes Minerais mediante a queima de leiras. ÁRVORE, Viçosa, $\underline{6}$ (1): 84-89, Janeiro a Junho 1982.

REZENDE, G.C.; BARROS, N.F.; MORAES, T.S.A.; MENDES, C.J. e SUITER FILHO, W. Aplicação de fosfatos naturais em plantios de E. grandis W. Hill ex Maiden. ÁRVORE, Viçosa, 6 6 (1): 74-83, Janeiro a Junho 1982.

1983: 11 trabalhos

BRAGA, J.M. e ROCHA, D. (1983) "Adubação Fosfatada em Eucalipto no Viveiro, II - Efeito da Época de Aplicação de Calcário e de Gesso na Eficiência dos Fosfatos de Araxá e de Patos." In: Congresso Florestal Brasileiro, 4., p. 195, Minas Gerais, Jan.Fev., 1983. 
CAPITANI, L. R. ; SPELTZ, G. E. e CAMPOS, W. O. (1983). "Efeitos da Calagem e Adubação Fosfatada no Desenvolvimento de Pinus caribaea Morelet var. hondurensis." In: Congresso Florestal Brasileiro, 4. Minas Gerais, Jan.-Fev. , 1983, p. 243-246.

CAPITANI, L.R.; SPELTZ, G.E. e CAMPOS, W.O. (1983 b) "Efeitos da Calagem e Adubação Fosfatada no Desenvolvimento de Pinus caribaea Morelet Var bahamensis." In: Congresso Florestal Brasileiro. 4., p. 235, Minas Gerais, Jan.-Fev., 1983.

CAPITANI, L.R.; SPELTZ, G.E. e CAMPOS, W.O. (1983 c) "Efeitos da Calagem e Adubação Fosfatada no Desenvolvimento de Pinus oocarpa Schiede." In: Congresso Florestal Brasileiro, 4., p. 239, Minas Gerais, Jan.-Fev., 1983.

PEREIRA, A. R. ; BARROS, N. F. e FLORES, C. (1983). "Uso da Moinha de Carvão Vegetal como Fonte de Nutrientes em Povoamentos de Eucaliptos." In: Congresso Florestal Brasileiro, 4. Minas Gerais, Jan.-Fev., 1983, p. 416-417.

REZENDE, G.C.; BARROS, N.F.; MORAES, T.S.A. e MENDES, C.J. Produção e macronutrientes em florestas de eucalipto sob duas densidades de plantio. ÁRVORE, Viçosa, Z(2): 165-176, Julho a Dezembro 1983.

REZENDE, G.C.; GONÇALVES, J.C. e SIMÕES, J.W. (1983) "Competição entre Fertilizantes Fosfatados em Plantio de Eucalipto." In: Congresso Florestal Brasileiro, 4., p. 451, Minas Gerais, Jan.-Fev., 1983.

ROCHA, D e BRAGA, J.M. (1983) "Adubação Fosfatada em Eucaliptos no Viveiro, I - Interação entre Espécies de Eucaliptos e Fontes de Fósforo." In: Congresso Florestal Brasileiro, 4., p. 455, Minas Gerais, Jan.-Fev., 1983.

ROCHA, D.; NASCIMENTO, M.B.Fo; MAGALHÃES, J.G.R. e FERNANDES, J.C. (1983 c) "Estudo de Fontes Naturais de Fósforo e Cálcio na 2a Rotação de Eucalyptus, na Região de Itamarandiba, MG." In: Congresso Florestal Brasileiro, 4., p. 473, Minas Gerais, Jan.-Fev., 1983.

ROCHA, D.; NASCIMENTO, M.B.Fo; MAGALHÃES, J.G.R. e FERNANDES, J.C. (1983 b) "Estudo de Adubação em E. grandis W. Hill. Ex. Maiden nos Solos de Cerrado na Região de Itamarandiba, MG." In: Congresso Florestal Brasileiro, 4., p. 470, Minas Gerais, Jan.-Fev., 1983.

VALERI, V. (1983). "Efeitos da Adubação NPK e do Calcário Dolomítico no Desenvolvimento de $E$. grandis Hill ex Maiden." In: Congresso Florestal Brasileiro, 4. Minas Gerais, Jan.-Fev. , 1983, p. 531-536.

1984: 2 trabalhos

LOCATELLI, M.; BARROS, N.F.; BRANDI, R.M.; NEVES, J.C.L. e GOMES, J.M. Efeito de fontes e doses de nitrogênio no crescimento de mudas de eucalipto. ÁRVORE, Viçosa, $\underline{8}(1): 39-52$, Janeiro a Junho 1984. 
LOCATELLI, M.; BARROS, N.F.; NEVES, J.C.L. e NOVAIS, R.F. Efeito de forma de nitrogênio sobre o crescimento e composição mineral de mudas de eucalipto. ÁRVORE, Viçosa, $\underline{8}(1)$ : 53-69, Janeiro a Junho 1984.

1985: 1 trabalho

VALERI, S.V.; AGUIAR, I.B.; CORRADINI, L.; SOUZA, E.C.A. e BANZATTO, D.A. Efeitos do fósforo e calcário dolomítio no desenvolvimento inicial de $E$. grandis Hill ex Maiden plantado em um Regossolo. IPEF, Piracicaba, (29): 55-60, Abril 1985.

1986: 5 trabalhos

BARROS, N.F.; NOVAIS, R.F.; CARMO, D.N. e NEVES, J.C.L. Classificação nutricional de sitios florestais - descrição de uma metodologia. ÁRVORE, Viçosa, 10(1): 112-120, Janeiro a Junho 1986.

BRITO, J.O.; FERRAZ, E.S.B.; BARRICHELO, L.E.G. e COUTO, H.T.Z. A adubação mineral e seus efeitos sobre os aneis de crescimento da madeira de $P$. caribaea var bahamensis. IPEF, Piracicaba, (32): 5-17, Abril 1986.

MARIANO, G. ; BUZATTO, O. ; CRESTANA, C. S. M. ; COELHO, L . C. C. ; TIMONI, J. L . e BERGAMASCO, A. (1986). "Pesquisa e Experimentação com o Suplemento Agrícola BioOrgânico Liquido Orgamen no Desenvolvimento de Mudas de $P$. caribaea var. caribaea." In: Congresso Florestal Brasileiro, 5. Pernambuco, Novembro, 1986, p. 67.

SULZBACHER, G. F. S. e KOIKE, E. G. (1986). "Influência do Composto Orgânico quando aplicados em florestas de Eucalyptus de diferentes idades." In: Congresso Florestal Brasileiro, 5. Pernambuco, Novembro, 1986, p. 67.

SULZBACHER, G.F.S. e KOIKE, E.G. (1986) "Influência do Composto Orgânico quando Aplicado em Florestas de Eucalyptus com diferentes Idades." In: Congresso Florestal Brasileiro, 4., p. 67, Olinda, Pernambuco, 23 a 28 de Novembro, 1986.

1988: 1 trabalho

STAPE, J.L. e BALLONI, E.A. O uso de resíduos da indústria de celulose como insumos na produção florestal. IPEF, Piracicaba, (40): 33-38, Dezembro 1988.

1990: 1 trabalho

FONSECA, S. ; MALUFE, J. L. P. e OLIVEIRA, A. C. (1990). "Adubação de E. camaldulensis com boro e zinco em solos de cerrado na região de Brasilândea, Minas Gerais." In: Congresso Florestal Brasileiro, 6., São Paulo, Setembro, 1990, p. 403-405.

1993: 3 trabalhos

FERREIRA, C. A. (1993) "Nutrição Mineral das Florestas Plantadas: o Estado Atual e Tendência da Pesquisa e da Prática." In: Congresso Florestal Panamericano/Congresso Florestal Brasileiro, 1./7., p.157, Curitiba, Paraná, 19 a 24 de Setembro, 1993. 
VALERI, S. V. ; PIRES, A. L. B. ; BANZATTO, D. A. ; CORRADINI, L. ; VALLE, C. F. (1993). "Efeitos da adubação NPK no desenvolvimento inicial de progênies de $E$. grandis Hill ex Maiden em condiçõos de casa-de-vegetação." In: Congresso Florestal Brasileiro, 7. , Paraná, Setembro, 1993, p. 245.

VALERI, S.V.; AGUIAR.; I.B. e CORRADINI, L. Composição química foliar e crescimento volumétrico de $E$. grandis Hill ex Maiden cultivado em areia quartzo, em resposta à aplicação de fósforo e calcário dolomitico. IPEF, Piracicaba, (46): 63-75, 1993.

1994: 5 trabalhos

ANDRADE, A.M.; VITAL, B.R.; BARROS, N.F.; LUCIA, R.M.D.; CAMPOS, J.C.C. e VALENTE, O.F. Efeitos da fertilização mineral e da calagem do solo na produção e na qualidade da madeira de eucalipto. ÁRVORE, Viçosa, 18(1): 69-78, Janeiro a Abril 1994.

CHICHORRO, J.F.; REZENDE, J.L.P.; CECON, P.R. e BARROS, N.F. Efeito do fertilizante na produtividade e economicidade do $E$. grandis, no município de Martinho Campos, MG. ÁRVORE, Viçosa, 18(1): 33-44, Janeiro a Abril 1994.

LANA, M.C. e NEVES, J.C.L. Capacidade de Suprimento de Potássio em solos sob reflorestamento com eucalipto do Estado de São Paulo. ÁRVORE, Viçosa, 18(2): 115-122, Maio a Agosto 1994.

OLIVEIRA, V.A.B.; NOVAIS, R.F.; NEVES, J.C.L.; BARROS, N.F. e LEAL, P.G.L. Raizes e tocos de mudas de Eucalyptus como fontes de nutrientes para as brotações. ÁRVORE, Viçosa, 18(1): 22-32, Janeiro a Abril 1994.

SHUMACHER, M.V.; POGGIANI, F. e SIMÕES, J.W. Transferências de nutrientes das copas para o solo através da deposição de folhedo em povoamentos de $E$. camaldulensis, $E$. grandis e $E$. torelliana, plantados em Anhembi, SP. IPEF, Piracicaba, (47): 51-56, Maio 1994.

\section{2) Novas Dosagens}

1973: 2 trabalhos

BRASIL, U.M.; SIMÕES, J.W. Determinação da dosagem de fertilizante mineral para a formação de mudas de eucalipto. IPEF, Piracicaba, (6): 79-85, 1973.

CARVAlHO, C.M. (1973) "Nota Prévia Sobre Alguns Problemas na Fertilização de E. saligna Smith (Deficiências de B, Zn e Cu)." In: Congresso Florestal Brasileiro, 2., p. 128, Curitiba, Paraná, 17 a 21 de Setembro, 1973.

1974: 1 trabalho

SIMÕES, J.W.; LEITE, N.B.; TANAKA, O.K. e ODA, S. Fertilização parcelada na produção de mudas de eucaliptos. IPEF, Piracicaba, (8): 99-109, Outubro 1974.

1976: 1 trabalho

HAAG, H.P.; SARRUGE, J.R.; OLIVEIRA, G.D.; POGGIANI, F. e FERREIRA, C.A. Análise foliar em cinco espécies de eucalipto. IPEF, Piracicaba, (13): 99-1 16, Dezembro 1976. 
1977: 2 trabalhos

FLOR, H.M. Estudos sobre produção e forma do fuste do Pinus taeda L. numa área de ensaio de adubação na fazenda Canguiri. FLORESTA, Curitiba, $\underline{8}(1)$ : 62-70, 1977.

HAAG, H.P.; SIMÕES, J.W.; OLIVEIRA, G.D.; SARRUGE, J.R. e POGGIANI, F. Distúrbios nutricionais em $E$. citriodora. IPEF, Piracicaba, (14): 59-68, Julho 1977.

1978: 2 trabalhos

CARVAlHO, C. M. ; VEIGA, R. A. A. ; BAENA, E. S. e COUTINHO, C. J. (1978). "Efeitos da Adubação Mineral (N x P x K x B) na Resistência à Geada do $E$. saligna $\mathrm{S}$. aos Seis meses de Idade." In: Congresso Florestal Brasileiro, 3. Amazonas, Dezembro, 1978, p. 57-59.

CARVALHO, C. M. ; BAENA, E. S. ; COUTINHO, C. J. ; FREITAS, M. e FERREIRA, C. A. (1978). "Estudos das Relações B/K e B/Ca na Cultura de Eucalyptus saligna Smith (Resultados preliminares)." In: Congresso Florestal Brasileiro, 3. Amazonas, Dezembro, 1978, p. 264266.

1979: 1 trabalho

NOVAIS, R.F.; GOMES, J.M.; ROCHA, D. e BORGES, E.E.L. Calagem e Adubação mineral na produção de mudas de eucalipto. (E. grandis W. Hill ex Maides). I. Efeitos da calagem e dos nutrientes N, P e K. ÁRVORE, Viçosa 32(2): 121-134, Julho a Dezembro 1979.

1980: 3 trabalhos

BELLOTE, A.F.J.; SARRUGE, J.R.; HAAG, H.P. e OLIVEIRA, G.D. Extração e exportação de nutrientes pelo $E$. grandis Hill ex Maiden em função da idade: 1- Macronutrientes. IPEF, Piracicaba, (20): 1-23, Junho 1980.

BELlOTE, A.F.J.; SARRUGE, J.R.; HAAG, H.P. e OLIVEIRA, G.D. Extração e exportação de nutrientes pelo $E$. grandis Hill ex Maiden em função da idade: 2- Micronutrientes. IPEF, Piracicaba, (20): 27-45, Junho 1980.

NOVAIS, R.F.; GOMES, J.M.; NASCIMENTO FILHO, M.B. e BORGES, E.E.L. Calagem e adubação mineral na produção de mudas de eucalipto ( $E$. grandis W. Hill ex Maides). III. Efeitos da calagem, do superfosfato simples e de um fertilizante NPK. ÁRVORE, Viçosa, 4(2): 111-123, Julho a Dezembro 1980.

1981: 1 trabalho

BARROS, N.F.; BRAGA, J.M.; BRANDI, R.M. e DEFELIPO, B.V. Produção de eucalipto em solos de cerrados em resposta à aplicação de NPK e de B e Zn. ÁRVORE, Viçosa, 5(1): 90-103, Janeiro a Junho de 1981.

1982: 6 trabalhos 
BARROS, N.F.; NOVAIS, R.F.; NEVES, J.C. e GOMES, J.M. Interpretação de Análises químicos de solos para o crescimento de Eucalyptus spp, ÁRVORE, Viçosa, $\underline{6}(1)$ : 38-44, Janeiro a Junho 1982.

NEVES, J.C.L.; NOVAIS, R.F. e BARROS, N.F. Efeito do Alumínio em solução nutritiva no crescimento e absorção de nutrientes por Eucalyptus spp. ÁRVORE, Viçosa, $\underline{6}(1)$ : 1-17, Janeiro a Junho 1982.

NEVES, J.C.L.; BARROS, N.F.; NOVAIS, R.F. e ANJOS, J.L. Efeito do Alumínio e, amostras de dois latossolos sob cerrado sobre o crescimento e a absorção de nutrientes de mudas de Eucalyptus spp. ÁRVORE, Viçosa, 6(1): 17-28, Janeiro a Junho 1982.

NOVAIS, R.F.; BARROS, N.F.; NEVES, J.C.L e COUTO, C. Niveis críticos de fósforo no solo para o eucalipto. ÁRVORE, Viçosa, 6(1): 29-37, Janeiro a Junho 1982.

NOVELINO, J.O.; NEVES, J.C.L.; BARROS, N.F.; NOVAIS, R.F. e MUNIZ, A.S. Efeito de níveis de Boro sem solução nutritiva no crescimento de Eucalyptus spp. ÁRVORE, Viçosa, $\underline{6}$ (1): $45-$ 51, Janeiro a Junho 1982.

VALE, F.R.; NOVAIS, R.F. e BARROS, N.F. Influência do Alumínio sobre a absorção de Nitrogênio e Fósforo por mudas de eucalipto. ÁRVORE, Viçosa, 6(1): 90-94, Janeiro a Junho 1982.

1983: 2 trabalhos

BALLONI, E.A.; GARCIA, P.V. e CONÇALVES, J.C. (1983) "Efeitos do Espaçamento e Adubação sobre a Recuperação de Plantio de E. grandis danificadas pela Geada." In: Congresso Florestal Brasileiro, 4., p. 172, Minas Gerais, Jan-Fev, 1983.

CAPITANI, L.R.; SPELTZ, G.E. e CAMPOS, W.O. (1983 a) "Adubação Fundamental por Omissão em Pinus oocarpa Schiede e Pinus caribaea Morelet Var. hondurensis Banet e Golfari, em Romaria, MG." In: Congresso Florestal Brasileiro, 4., p. 231, Minas Gerais, Jan.-Fev, 1983.

1984: 5 trabalhos

BARROS, R.F.; SILVA, O.M.; PEREIRA, A.R.; BRAGA, J.M. e LUDWIG, A. Análise do crescimento de $E$. saligna em solo de Cerrado sob diferentes niveis de $\mathrm{N}, \mathrm{P}$ e $\mathrm{K}$ no Vale do Jequitinhonha, MG. IPEF, Piracicaba, (26): 13-17, Abril 1984.

FRANÇA, F.S.; MARTINI, S.L.; SIMIÕES, J.W. e SILVA, M.G. Efeito das doses crescentes de fertilizantes minerais aplicados no plantio de E. grandis. IPEF, Piracicaba, (26): 37-38, Abril 1984.

LA TORRACA, S.M.; HAAG, H.P. e MICLIORINI, A.J. Recrutamento e exportação de nutrientes por Pinus elliottü var. elliottü em um latossolo vermelho escuro na região de Agudos, SP.IPEF, Piracicaba, (27): 41-47, Agosto 1984.

LOCATELLI, M.; BARROS, N.F.; BRANDI, R.M.; NEVES, J.C.L. e GOMES, J.M. Efeito de fontes e doses de nitrogênio no crescimento de mudas de eucalipto. ÁRVORE, Viçosa, $\underline{8}(1)$ : $39-52$, Janeiro a Junho 1984. 
VALE, F.R.; NOVAIS, R.F.; BARROS, N.F. e SANT'ANA, R. Efeito do Alumínio sobre a Cinética de absorção de amônio e Nitrato em raizes intactas de Eucalyptus alba. ÁRVORE, Viçosa, 8(2): 123-132, Julho a Dezembro 1984.

\section{6: 3 trabalhos}

GONÇALVES, J.L.M.; BARROS, N.F.; NEVES, J.C.L. e NOVAIS, R.B. Níveis críticos de fósforo no solo e na parte aérea de eucalipto na presença e ausência de calagem. ÁRVORE, Viçosa, 10(1): 91-104, Janeiro e Junho 1986.

NOVAIS, R.F.; BARROS, N.F. e NEVES, J.C.L. Interpretação de análise química do solo para o crescimento e desenvolvimento de Eucalyptus spp - niveis críticos de implantação e de manutenção. ÁRVORE, Viçosa, 10(1): 105-111, Janeiro a Junho 1986.

TIMONI, J. L. e PAGANO, J. N (1986). "Caracterização e Quantificação de Elementos Minerais de um Povoamento de $P$. kesiya Royle ex Gordon no Municipio de Itirapina-SP." In: Congresso Florestal Brasileiro, 5. Pernambuco, Novembro, 1986, p. 69.

1989: 2 trabalhos

OLIVA, M.A.; BARROS, N.F.; GOMES, M.M.S. e LOPES, N.F. Seca de ponteiros em $E$. camaldulensis Dehn em relação ao estresse hídrico e nutrição mineral. ÁRVORE, Viçosa, 133(1): 19-33, Janeiro a Junho 1989.

SOARES, I; BORGES, A.C.; BARROS, N.F.; NEVES, J.C. e BELLEI, M.M. Teor de fósforo no solo influenciando o desenvolvimento de ectomiconizas e nutrição e crescimento de mudas de eucalipto. ÁRVORE, Viçosa, 13(2): 140-151, Julho a Dezembro 1989.

1990: 2 trabalhos

NADOLNY, M.C. Efeito da omissão de nutrientes no desenvolvimento e no estado nutricional de $P$. taeda L, durante a fase de viveiro. FLORESTA, Curitiba, 20(1/2): 112-113, Junho e Dezembro 1990.

STAPE, J. L. e ZANI FILHO, J. (1990). "Aumento da produtividade do E. grandis, em areias quartzosas, através da fertilização de manutenção." In: Congresso Florestal Brasileiro, 6. São Paulo, Setembro, 1990, p. 386-389.

1992: 1 trabalho

CHICHORRO, J.F.; REZENDE, J.L.P. e BARROS, N.F. Eficiência econômica da nutrição mineral na produção de biomassa de E. grandis. ÁRVORE, Viçosa, 16(3): 287-300, Setembro a Dezembro 1992.

\section{3: 3 trabalhos}

DRUMOND, M. A. ; BARROS, N. F. ; RODRIGUES, B. S. A. ; FONTE, A. J. C. e PASSOS, M. A. (1993). "Efeitos dos niveis de fósforo sobre o desenvolvimento do Eucalyptus urophylla na 
Região de Itaporanga, SE. ." In: Congresso Florestal Brasileiro, 7. , Paraná, Setembro, 1993, p. 243.

FERREIRA, C. A. ; BELLOTE, A. F. J. e SILVA, H. D. (1993). "Concentração de nutrientes minerais no lenho de $E$. saligna e sua relação com a aplicação de fertilizantes." In: Congresso Florestal Brasileiro, 7. , Paraná, Setembro, 1993, p. 227-230.

VALERI, S. V. ; ARAÚJO, J. A. C. e PRETTI JÚNIOR, L. (1993). "Efeitos do nitrogênio, potássio e calagem no desenvolvimento e composição química foliar de $E$. urophylla $\mathbf{s}$. t. Blake cultivada sob. dois regimes hídricos, em casa-de-vegetação." In: Congresso Florestal Brasileiro, 7., Paraná, Setembro, 1993, p. 246-248. *

\section{3) Calagem e Gessagem}

1979: 1 trabalho

NOVAIS, R.F.; GOMES, J.M.; ROCHA, D. e BORGES, E.E.L. Calagem e Adubação mineral na produção de mudas de eucalipto. ( $E$. grandis W. Hill ex Maides). I. Efeitos da calagem e dos nutrientes N, P e K. ÁRVORE, Viçosa 3 (2): 121-134, Julho a Dezembro 1979.

1980: 1 trabalho

NOVAIS, R.F.; GOMES, J.M.; NASCIMENTO FILHO, M.B. e BORGES, E.E.L. Calagem e adubação mineral na produção de mudas de eucalipto (E. grandis W. Hill ex Maides). III. Efeitos da calagem, do superfosfato simples e de um fertilizante NPK. ÁRVORE, Viçosa, 4(2): 111-123, Julho a Dezembro 1980.

1983: 5 trabalhos

BRAGA, J.M. e ROCHA, D. (1983) "Adubação Fosfatada em Eucalipto no Viveiro, II - Efeito da Época de Aplicação de Calcário e de Gesso na Eficiência dos Fosfatos de Araxá e de Patos." In: Congresso Florestal Brasileiro, 4., p. 195, Minas Gerais, Jan.Fev., 1983.

CAPITANI, L.R.; SPELTZ, G.E. e CAMPOS, W.O. (1983 b) "Efeitos da Calagem e Adubação Fosfatada no Desenvolvimento de Pinus caribaea Morelet Var bahamensis." In: Congresso Florestal Brasileiro, 4., p. 235, Minas Gerais, Jan.-Fev., 1983.

CAPITANI, L.R.; SPELTZ, G.E. e CAMPOS, W.O. (1983 c) "Efeitos da Calagem e Adubação Fosfatada no Desenvolvimento de Pinus oocarpa Schiede." In: Congresso Florestal Brasileiro, 4., p. 239, Minas Gerais, Jan.-Fev., 1983.

CAPITANI, L. R. ; SPELTZ, G. E. e CAMPOS, W. O. (1983). "Efeitos da Calagem e Adubação Fosfatada no Desenvolvimento de Pinus caribaea Morelet var. hondurensis." In: Congresso Florestal Brasileiro, 4. Minas Gerais, Jan.-Fev. , 1983, p. 243-246.

VALERI, V. (1983). "Efeitos da Adubação NPK e do Calcário Dolomítico no Desenvolvimento de $E$. grandis Hill ex Maiden." In: Congresso Florestal Brasileiro, 4. Minas Gerais, Jan.-Fev. , 1983, p. $531-536$. 
VALERI, S.V.; AGUIAR, I.B.; CORRADINI, L.; SOUZA, E.C.A. e BANZATTO, D.A. Efeitos do fósforo e calcário dolomítio no desenvolvimento inicial de $E$. grandis Hill ex Maiden plantado em um Regossolo. IPEF, Piracicaba, (29): 55-60, Abril 1985.

1990: 1 trabalho

GOULART, R. V. ; TEIXEIRA, J. L. ; NOVAIS, R. F. ; BARROS, N. F. e MACEDO, P. R. 0. (1990). "Respostas de Mudas de Eucalyptus spp à calagem." In: Congresso Florestal Brasileiro, 6. , São Paulo, Setembro, 1990, p. 456-458.

1993: 4 trabalhos

SILVA, D.J. e DEFELIPO, B.V. Necessidade de calagem e diferentes relações Ca: $\mathbf{M g}$ para a produção de eucalipto. ÁRVORE, Viçosa, 17(3): 303-313, Setembro a Dezembro 1993.

VALERI, S. V. ; ARAÚJO, J. A. C. e PRETTI JÚNIOR, L. (1993). "Efeitos do nitrogênio, potássio e calagem no desenvolvimento e composição química foliar de $E$. urophylla s. t. Blake cultivada sob. dois regimes hídricos, em casa-de-vegetação." In: Congresso Florestal Brasileiro, 7., Paraná, Setembro, 1993, p. 246-248.

VALERI, S.V.; AGUIAR; I.B. e CORRADINI, L. Composição química foliar e crescimento volumétrico de $E$. grandis Hill ex Maiden cultivado em areia quartzo, em resposta à aplicação de fósforo e calcário dolomítico. IPEF, Piracicaba, (46): 63-75, 1993.

VILLAS BOAS, R. L. e GUERRINI, I. A. (1993). "Efeito do cálcio e do ph no desenvolvimento inicial de E. saligna." In: Congresso Florestal Brasileiro, 7. , Paraná, Setembro, 1993, p. 240-242.

1994: 1 trabalho

ANDRADE, A.M.; VITAL, B.R.; BARROS, N.F.; LUCIA, R.M.D.; CAMPOS, J.C.C. e VALENTE, O.F. Efeitos da fertilização mineral e da calagem do solo na produção e na qualidade da madeira de eucalipto. ÁRVORE, Viçosa, 18 (1): 69-78, Janeiro a Abril 1994.

6) Mecanização

6.1) Sementes/Plantio

1973: 2 trabalhos

CARNEIRO, D.A. (1973) "Semeadeira de Tração Manual Modelo Klabin." In: Congresso Florestal Brasileiro, 2., p. 287, Curitiba, Paraná, 17 a 21 de Setembro, 1973.

SPELTZ, R.M. e BONISCH, H.J. (1973) "Máquina para Beneficiamento de Sementes de Pinus spp." In: Congresso Florestal Brasileiro, 2., p. 91, Curitiba, Paraná, 17 a 21 de Setembro, 1973.

1992: 1 trabalho 
CARNEIRO, J.G.A. e BRITO, M.A.R. Nova metodologia para produção mecanizada de mudas de P. taeda L. em recipientes com raizes laterais podadas. FLORESTA, Curitiba, 22(1/2): 111, Junho e Dezembro 1992.

\section{2) Manejo}

1973: 1 trabalho

MONTEIRO, H.M.; DYBSJORD, R. e BRATEN, S. (1973a) "Organização, Método e Controle dos Trabalhos de Corte Mecanizados." In: Congresso Florestal Brasileiro, 2., p. 285, Curitiba, Paraná, 17 a 21 de Setembro, 1973.

1983: 3 trabalhos

CAMPINHOS, E. Jr; ALVES, J.E.M.; SANTOS, J.S.F. e SOUZA, W (1983b) "Desenvolvimento de Equipamento para Aplicação de Formicida Termonebulizável." In: Congresso Florestal Brasileiro, 4., p. 229, Minas Gerais, Jan.-Fev., 1983.

GRUPO RIPASA (1983) "Reformas de Povoamento de Eucalyptus - Estudos de Alternativas Operacionais." In: Congresso Florestal Brasileiro, 4., p. 269, Curitiba, Paraná, 17 a 21 de Setembro, 1983

VIEIRA, L. B. e SILVA, E. F. (1983). "Teste de Máquina Levco 540 na Eliminação de Tocos de Eucaliptos." In: Congresso Florestal Brasileiro, 4. Minas Gerais, Jan.-Fev., 1983, p. 608.

1984: 1 trabalho

CRUZ, J.M.; NOGUEIRA, S.B.; PEREIRA, A.R. e MEWES, B.O. Adaptação de uma motocicleta para termonebulização no controle de formigas salivas (Atta spp), em áreas reflorestadas do

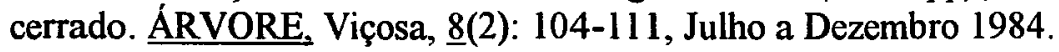

1990: 1 trabalho

GUERREIRO, C.A.; ROMERO, A. WADOUSKI, L.H. (1990) "Desenvolvimento de um rebaixador mecanizado de Cepas." In: Congresso Florestal Brasileiro, 6., p. 4, Campos do Jordão, São Paulo, 27 de Setembro, 1990.

\section{3) Exploração}

1953: 1 trabalho

SAUR, W.W. (1953) "Formas de Exploração Racional das Florestas." In: Congresso Florestal Brasileiro, 1., p. 275, Curitiba, Paraná, 13 a 19 de Setembro, 1953.

1973: 1 trabalho

MONTEIRO, H.M.; DYBSJORD, R. e BRATEN, S. (1973 b) "Uso de Tratores Madereiros (Forwarders) no Rio Grande do Sul." In: Congresso Florestal Brasileiro, 2., p. 288, Curitiba, Paraná, 17 a 21 de Setembro, 1973. 
1976: 1 trabalho

STÖHR, G.W.D. Análise de sistema na exploração e transporte em florestas plantadas. FLORESTA, Curitiba, I(1): 57-76, 1976.

1978: 1 trabalho

LELLES, J.G.; SOUZA, A.P.; BARROS, A.A.A. e VALENTE, O.F. Rendimentos e Custos no corte de eucaliptos com machado e motosserra. ÁRVORE, Viçosa, 2(1): 20-26, Janeiro a Julho 1978.

1983: 2 trabalhos

SEIXAS, F. Aspectos atuais e perspectivas de desenvolvimento em exploração florestal. IPEF, Piracicaba, (25): 9-14, Dezembro 1983.

SUZUKI, T.; KOBAYASHI, M.; BUCCI, L.A. e MOTTA, J.M. (1983) "Mecanização de Exploração Florestal em Campos do Jordão." In: Congresso Florestal Brasileiro, 4., p. 604, Minas Gerais, Jan.-Fev., 1983.

1986: 5 trabalhos

MESQUITA, R. ; DONATI, Z. A. e LÍRIO, A. J. (1986). "O uso do treminhão no transporte de madeira na Aracruz Florestal S. A. ." In: Congresso Florestal Brasileiro, 5. Pernambuco, Novembro, 1986, p. 135.

MONTEIRO, H. M. e PIVETTA, A. B. (1986). "Técnica de Corte." In: Congresso Florestal Brasileiro, 5. Pernambuco, Novembro, 1986, p. 135.

SEIXAS, F. (1986). "Estudo comparativo entre dois sistemas operacionais de transporte utilizando toras de comprimentos variados." In: Congresso Florestal Brasileiro, 5. Pernambuco, Novembro, 1986, p. 135.

SEIXAS, F. Estudo comparativo entre dois sistemas operacionais de transporte utilizando toras de comprimentos variados. IPEF, Piracicaba, (33): 27-30 Agosto 1986.

SEIXAS, F. Planejamento e estudo de sistema de exploração florestal. IPEF, Piracicaba, (34): 25-30, Dezembro 1986.

1993: 2 trabalhos

FREITAS, M. e ANTIQUEIRA, A. C. (1993). "Sistema mecanizado de colheta florestal na Champion Papel e Celulose Ltda." In: Congresso Florestal Brasileiro, 7., Paraná, Setembro, 1993, p. 686-687.

RIBAS JÚNIOR, U. e MENDES NETO (1993). "O uso de guincho de arraste na colheita florestal." In:: Congresso Florestal Brasileiro, 7., Paraná, Setembro, 1993, p. 682-685.

\section{7) Gerencial}




\section{1) Inventário}

1972: 2 trabalhos

VEIGA, R.A.A. Comparação de equações de volume para $E$. saligna Smith I. Equações aritméticas nãoformais. FLORESTA, Curitiba, 4(1): 81-94, Dezembro 1972.

VEIGA, R.A.A. Comparação de equações de volume para E. saligna Smith II. Equações aritméticas formais. FLORESTA, Curitiba, 4(1): 95-104, Dezembro 1972.

1973: 3 trabalhos

MACHADO, S.A. (1973) "Aplicabilidade de Equação de Regressão em Inventários Florestais." In: Congresso Florestal Brasileiro, 2., p. 175, Curitiba, Paraná, Set. 1973.

SERRA FILHO, R. e CHIARINI, J.V. (1973) "Cobertura Vegetal do Estado de São Paulo - Avaliação Volumétrica das Florestas de Pinus e Eucalyptus." In: Congresso Florestal Brasileiro, 2., p. 181, Curitiba, Paraná, 17 a 21 de Setembro, 1973.

VEIGA, R.A.A. Comparação de equações de volume para E. saligna Smith III. Equações logaritmicas formais e não formais. FLORESTA, Curitiba, 4(1): 5-14, 1973.

1977: 3 trabalhos

FERREIRA, C.A.; MELLO, H.A. e KAJICA, S. Estimativa do volume de madeira aproveitável para celulose em povoamentos de Eucalyptus spp: Determinação de equação para o cálculo de volume de povoamentos de Eucalyptus spp. IPEF, Piracicaba, (14): 29-50, Julho 1977.

PAULA NETO, F.; BRANDI, R.M.; RIBEIRO, J.C. e GUIMARÃES, D.P. Teste de aplicação de tabelas volumétricas para estimar a produção de plantações de $E$. paniculata $\mathrm{Sm}$., na região de Ipatinga, Minas Gerais. ÁRVORE, Viçosa, 1 (2): 154-166, Julho a Dezembro 1977.

PRODAM, M. Inventário florestal intensivo para obtenção de meios e tabelas auxiliares para atividade florestal nos países em desenvolvimento. FLORESTA, Curitiba, $\underline{8}(2): 5-13,1977$.

1978: 2 trabalhos

OGAWA, H. Y. ; KRONKA, F. J. N. ; LIMA, O. S. ; GALLOZZI, A. C. ; ANDRADE, G. G. ; BORGES, M. H. e ANDRADE, W. J. (1978). "Inventário Florestal do Estado de São Paulo." In: Congresso Florestal Brasileiro, 3. Amazonas, Dezembro, 1978, p. 278-280.

SILVA, J.A.A.; PAULA NETO, R.; BRANDI, R.M. e CONDÉ, A.R. Análise de modelos volumétricos para construção de tabelas de volume comercial de Eucalyptus spp segundo a espécie, a região e os métodos de regeneração. ÁRVORE, Viçosa, 2(1): 86-99, Janeiro a Julho 1978.

1981: 1 trabalho

SCOLFORO, J.R.S.; PAULA NETO, F.; ASPIAZÚ, C. e CONDÉ, A.R. Análise comparativa dos procedimentos de inventários florestais repetidos em povoamentos de Eucalyptus spp na região de Bom Despacho. ÁRVORE, Viçosa, 5 (1): 56-72, Janeiro a Junho 1981. 
1983: 4 trabalhos

AOKI, H. e CHO, M. (1983) "Inventário Florestal através do Uso de Fotografias Aéreas Verticais." In: Congresso Florestal Brasileiro, 4., p. 623, Minas Gerais, Jan-Fev. 1983.

CHO, M. ; HAGA, N. e YAMAZOE, G. (1983). "Elaboração de Tabela de Rendimento para Pinus elliottii var. elliottii Eng." In: Congresso Florestal Brasileiro, 4. p. 619-622, Minas Gerais, Jan.- Fev., 1983,

PAULA NETO, F.; SOUZA, A.L.; QUINTAES, P.C.G. e SOARES, V.P. Análise de equações volumétricas para Eucalyptus spp, segundo o método de regeneração na Região de José de Melo-MG. ÁRVORE, Viçosa, 7(1):56-70, Janeiro a Junho 1983.

RIBEIRO, R. A. S. (1983). "Sistema Automatizado para Processamento de Dados de Inventário Florestal para a Região Amazônica - Invet." In: Congresso Florestal Brasileiro, 4. Minas Gerais, Jan.-Fev. , 1983, p. 690-694.

\section{5: 1 trabalho}

CAMPOS, J.C.C.; TORQUATO, M.C. e RIBEIRO, G.A. Equação para Calcular índices de local e

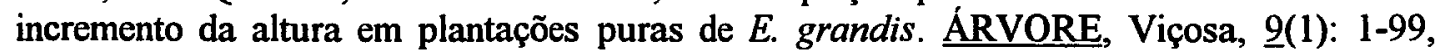
Janeiro a Julho 1985.

1986: 4 trabalhos

CAMPOS, J.C.C.; TREVIZOL JÚNIOR, T.L.; TORQUATO, M.C.; PAULA NETO, F. e VALE, A.B. Aplicação de um modelo compativel de crescimento e produção de densidade variável em plantações de $E$. grandis. ÁRVORE, Viçosa, 10(2): 121-134, Julho a Dezembro 1986.

COUTO, H.T.Z.; BASTOS, N.L.M. Curvas de crescimento para Eucalyptus em $2^{a}$ rotação no Estado de São Paulo. IPEF, Piracicaba, (34): 15-21, Dezembro de 1986

REZENDE, M.A. e FERRAZ, E.S.B. Incrementos anuais de volume, massa e idade ideal para $E$. grandi. IPEF, Piracicaba, (32): 43-48, Abril 1986.

TIMONI, J. L. ; COELHO, L. C. C. ; BUZATTO, O. ; GIANOTTI, E e VEIGA, J. E. R. (1986). "Determinação de equações de volume para $P$. kesiya Rơyle ex Gordon no Município de Itirapina-SP." In: Congresso Florestal Brasileiro, 5. Pernambuco, Novembro, 1986, p. 171.

1987: 1 trabalho

COUTO, H.T.Z.; BASTOS, N.L.M. Modelos de equações de volume e relações hiprométricas para plantações de Eucalyptus no Estado de São Paulo IPEF, Piracicaba, (37): 14-19, Dezembro de 1987

1988: 1 trabalho

GOMES, F.P. e CHAVES, R. A amostragem ótima em inventário florestal. IPEF, Piracicaba, (38): 1722, Abril de 1988. 
1989: 1 trabalho

McTAGUE, J.P.; BATISTA,J.L.F. e STEINER, L.H Equação de volume total, volume comercial e forma do tronco para plantação de Eucalyptus nos Estados de São Paulo e Rio de Janeiro. IPEF, Piracicaba, (41/42): 56-63, 1989.

1990: 10 trabalhos

AMORIN, H. B. e PAULA NETO, S. (1990). "Inventário Florestal Nacional - uma proposta para o caso brasileiro." In: Congresso Florestal Brasileiro, 6. , São Paulo, Setembro, 1990, p. 121-130.

COUTO, H.T.Z.; BASTOS, N.L.M. e LACERDA, J.S. A amostragem por pontos na estimativa da altura de árvores dominantes e números de árvores por hectare em povoamentos de $E$. saligna. IPEF, Piracicaba, (43/44): 50-53, 1990.

FIATES, A.R. Funções de volume para povoamentos de $P$. elliottii var. elliottii e $P$. taeda L. para regiões de Itararé (SP) e Sengés (PR). FLORESTA, Curitiba, 20(1/2): 8-9, Junho e Dezembro 1990.

GUIMARÃES, D.P. Estimativa do volume de Eucalyptus spp através de posições absolutas dos troncos. FLORESTA, Curitiba, 20(1/2): 32-33, Junho e Dezembro 1990.

LEITE, H.G.; CAMPOS, J.C.C.; REGAZZI, A.J. e COUTO, L. Um modelo para estimar a produção de madeira para celulose e energia derivado da função Weibull. ÁRVORE, Viçosa, 14(2): 102118, Julho a Dezembro 1990.

MARCOLIN, M. Polimorfismo e tamanho da amostra para construção de curvas de índice de sítio para $P$. taeda L., no segundo planalto paranaense. FLORESTA, Curitiba, 20(1/2): 112, Junho e Dezembro 1990.

MENDES, J.B. Desenvolvimento de um sistema de inventário florestal por computador. FLORESTA, Curitiba, 20(1/2): 70-71, Junho e Dezembro 1990.

MENEGOL, O. e LOUZADA, P. T. C. (1990). "Desenvolvimento de metodologia de inventário florestal contínuo em Eucalyptus para classificação de sítio." In: Congresso Florestal Brasileiro, 6. , São Paulo, Setembro, 1990, p. 61-66.

ROSOT, M. A. ; MACHADO, S. A. ; ROSOT, N. C. e EMERENCIANO, D. B. (1990). "Estudo de modelos matemáticos para estimar o volume por hectare em um povoamento de $P$. taeda $\mathrm{L}$. em Piraí do Sul-PR." In: Congresso Florestal Brasileiro, 6. , São Paulo, Setembro, 1990, p. 111-120.

ROSOT, M.A.D. Estudo comparativo de métodos para a avaliação volumétrica por unidade de área em povoamento de $P$. taeda L. FLORESTA, Curitiba, 20(1/2): 99-100, Junho e Dezembro 1990.

1991: 2 trabalhos 
GANTZEL, O.L. Análise da eficiência e precisão das técnicas de medição de área: uma simulação florestal. FLORESTA, Curitiba, 21(1/2): 87-88, Junho e Dezembro 1991.

SILVA, J.A.A. e BAILEY, R.L. O uso de transformações normalizadoras no ajuste de modelos volumétricos. ÁRVORE, Viçosa, 15(2): 199-206, Julho a Dezembro 1991.

1992: 2 trabalhos

SCOLFORO, J.R.S. Curvas de índice de sítio para Pinus caribae van hondurensis. $\underline{\text { IPEF}}$, Piracicaba, (45): 40-47, 1992.

SCOLFORO, J.R.S. Um modelo de crescimento e produção para $P$. caribaea var hondurensis sujeito a desbastes. ÁRVORE, Viçosa, 16(2): !44-156, maio a Agosto 1992.

1993: 5 trabalhos

BRENA, D. A. e PÉLLICO NETTO, S. (1993). "Metodologia para determinação da intensidade amostral em inventários florestais contínuos com dupla amostragem." In: Congresso Florestal Brasileiro, 7. , Paraná, Setembro, 1993, p. 525-527.

COUTO, H.T.Z.; BASTOS, N.L.M. e LACERDA, J.S. A amostragem por pontos na estimativa de área basal em povoamentos de Eucalyptus. IPEF, Piracicaba, (46): 86-95, 1993.

FIGUEIREDO FILHO, A. ; OLIVEIRA, C. G. ; MOURA, J. B. e CUNHA, U. S. (1993). "Conversão de equações de volume em equações de forma compatíveis para Pinus elliottii." In: Congresso Florestal Brasileiro, 7. , Paraná, Setembro, 1993, p. 501-504.

MATOS, F. D. A. e KIREHNER, F. F. (1993). "Identificação de estratos de reflorestamento de Pinus taeda através de imagens digitais de Landsat-5." In: Congresso Florestal Brasileiro, 7. , Paraná, Setembro, 1993, p. 516-519.

SILVA, J. A. A. ; MACHADO, S. A. ; BORDERS, B. E. e BAILEY, R. L. (1993). "Uma nova metodologia para construção de tabelas volumétricas." In: Congresso Florestal Brasileiro, 7. , Paraná, Setembro, 1993, p. 557-558.

\section{2) Especialização/Otimização}

1970: 2 trabalhos

ALBUQUERQUE, M.V. Descrição e análise dos controles dos serviços motomecanizados no Departamento Florestal das I.K.P.C. S/A. FLORESTA, Curitiba, 2(2): 75-88, Janeiro 1970.

SILVA, J.C. Aspectos econômicos do desbaste em reflorestamento no Norte do Paraná. FLORESTA, Curitiba, 2(3): 12-24, Dezembro 1970.

1972: 1 trabalho 
MELLO, H.A.; COELHO, A.S.R.; CIERI NETO, A.; SIMÕES, J.W.; BERGER, R. e COUTO, H. T.Z. A influência da espécie, do espaçamento e da idade no custo de produção de madeira industrial. IPEF, Piracicaba, (5): 17-28, 1972.

1973: 3 trabalhos

BAENA, E.S. (1973) "Nota Prévia Sobre a Viabilidade Econômica da Eliminação Química de Brotas de Eucalipto." In: Congresso Florestal Brasileiro, 2., p. 135, Curitiba, Paraná, 17 a 21 Set., 1973.

HOFFMANN, R. e BERGER, R, Determinação da idade ótima de corte de povoamento de Eucalyptus. IPEF, Piracicaba, (7): 49-69, 1973.

RAMALHO, L.R. e BAENA, E.S. (1973) "Comparação de Custos para Desinfetação de Canteiros de Eucalyptus spp." In: Congresso Florestal Brasileiro, 2., p. 136, Curitiba, Paraná 17 a 21 de Setembro, 1973.

1974: 1 trabalho

BERGER, R.; SIMÕES, J.W. e LEITE, N.B. Métodos para avaliar economicamente a reforma de povoamento de Eucalyptus spp. IPEF, Piracicaba, (8): 55-62, Outubro 1974.

1976: 2 trabalhos

BERGER, R. e ENGLER, J.J.C. Minimização do custo de transporte de madeira de eucalipto no Estado de São Paulo. IPEF, Piracicaba, (12): 1-52, Junho 1976.

DISPERATI, A.A. e KEECH, M.A. Uso da imagem satélite para o desenvolvimento florestal. FLORESTA, Curitiba, 7(1): 46-51, 1976.

1977: 2 trabalhos

COUTO, L.; ZANUNCIO, J.C.; ALVES, J.E.M.; CAMPINHOS JÚNIOR, E.; SORESINE, L. e VARGAS, J.A. Avaliação da eficiência e custo do controle de Atta sexdens rubropilosa através do sistema termo-nebulizador, na Região de Aracruz, E.S. ÁRVORE, Viçosa, 1 (1): 9-16, Março 1977.

STÖHR, G.W.D. Cálculo de custos de máquinas florestais. FLORESTA, Curitiba, 8(2): 23-30, 1977.

1978: 6 trabalhos

LELLES, J.G.; SOUZA, A.P.; BARROS, A.A.A. e VALENTE, O.F. Rendimentos e Custos no corte de eucaliptos com machado e motosserra. ÁRVORE, Viçosa, 2(1): 20-26, Janeiro a Julho 1978.

NICOLIELO, N. e BERTOLANI, F. (1978). "Estudo para Determinação de Dimensões e Formas de Unidades de Amostra para Estimativa de Volume em Florestas Implantadas de Pinus Tropicais." In: Congresso Florestal Brasileiro, 3. Amazonas, Dezembro, 1978, p. 139-141. 
SHIMABUKURO, Y.E.; HERNANDES FILHO, P.; KOFFER, N.F.; CHEN, S.C. Classificação automotiva de reflorestamentos de Pinus spp e Eucalyptus spp em Mogi Guaçu-SP utilizando dados do satélite Landxit. IPEF, Piracicaba,, (16): 74-87, Junho 1978.

SOUZA, A.P.; LELLES, J.G.; GOMES, J.M. e VALENTE, O.F. Um estudo de tempo e produção na exploração de povoamentos jovens de Douglas-Fir com motosserras e "skider". ÁRVORE, Viçosa, 2(1): 1-19, Janeiro a Julho 1978.

SPELTZ, G. E. e DISSMAN, W. (1978). "Aspectos Econômicos da Desrama Artificial em Pinus Tropicais." In: Congresso Florestal Brasileiro, 3. Amazonas, Dezembro, 1978, p. 311-314.

STÖHR, G.W.D. e LEINERT, S. Importância e aplicação do estudo do trabalho. FLORESTA, Curitiba, 9(1): 27-36, 1978.

1980: 2 trabalhos

BERGER, R. e GARLIPP, R.C.D. Aspectos econômicos do emprego de fertilizantes minerais na produção de madeira de E. saligna no Estado de São Paulo. IPEF, Piracicaba, (20): 49-58, Julho 1980.

PAULA JÚNIOR, G.G. e PEREIRA, A.R. Dimensionamento de uma frota de caminhões para transporte de carvão vegetal por meio de programação linear. IPEF, Piracicaba, (21): 85-95, Dezembro 1980.

1981: 4 trabalhos

CAMPOS, J.C.C. e TURNBULL, K.J. Um sistema para estimar produção por classe de diâmetro e sua

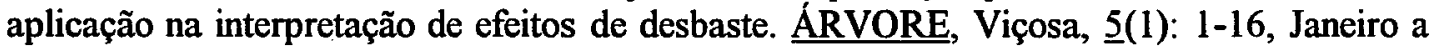
Junho 1981.

KIRCHNER, F.F. Sistema ecológico de classificação de cobertura da terra por sensoriamento remoto. FLORESTA, Curitiba, 12(1): 4-16, Junho 1981.

NEVES, A.R.; LADEIRA, H.P.; PAULA NETO, F. e ALVARENGA, S.C. Avaliação sócio-econômica de um programa de reflorestamento na região de Carbonita, Vale do Jequitinhonha, MG. ÁRVORE, Viçosa, $\underline{5}(1): 80-89$, Janeiro a Junho 1981.

PAULA NETO, F.; SOARES, V.P.; SOUZA, A.L. e RIBEIRO, J.C. Influência do tamanho e da forma de unidades de amostra na estimativa do volume, número de árvore e porcentagem de sobrevivência de plantações de E. grandis, na região de Bom Despacho, MG. ÁRVORE, Viçosa, 5(2): 148-160, Julho a Dezembro 1981.

1982: 1 trabalho

PEREIRA, A.R. e BRANDI, R.M. Minimização de custos na formação de florestas com alta densidade de plantas por área. ÁRVORE, Viçosa, $\underline{6}$ (2): 166-169, Julho a Dezembro 1982.

1983: 11 trabalhos 
AHRENS, S. (1983). "Importância de Distribuição de Resíduos de Regressão na Seleção de Equações de Volume." In: Congresso Florestal Brasileiro, 4. Minas Gerais, Jan.-Fev. , 1983, p. 609-614.

ANCILLOTTI, R.N.; SANTOS, R.J.; OLIVEIRA, E.S. e OST, V. (1983) "Evolução Metodológica no Corte e Transporte de Madeira - Feed-back de Treinamento." In: Congresso Florestal Brasileiro, 4., p. 551, Minas Gerais, Jan.-Fev., 1983.

HIGUCHI, N. ; SANTOS, J. e JARDIM, F. C. S. (1983). "Tamanho de Parcela Amostral para Inventários Florestais." In: Congresso Florestal Brasileiro, 4. Minas Gerais, Jan.-Fev. , 1983 , p. 649-650.

LACERDA, E. (1983). "A motosserra na Exploração Florestal - Aspectos Ergonômicos no seu Uso - A segurança e a Medicina do Trabalho." In: Congresso Florestal Brasileiro, 4. Minas Gerais, Jan.-Fev. , 1983, p. 565-566.

PAULA NETO, F. (1983). "Utilização da Amostragem por Ponto Horizontal em Conjunto com Equações de Volume da Variável Combinada." In: Congresso Florestal Brasileiro, 4. Minas Gerais, Jan.-Fev. , 1983, p. 682-685.

PEREIRA, A. R. e LADEIRA, H. P. (1983). "Custos de Desbrota em Povoamentos de Eucaliptos." In: Congresso Florestal Brasileiro, 4. Minas Gerais, Jan.-Fev. , 1983, p. 422-423.

PEREIRA, A. R. e PAULA JÚNIOR, G. G. (1983). "Influência da Produtividade Florestal nos Custos de Transporte de Carvão Vegetal no Estado de Minas Gerais." In: Congresso Florestal Brasileiro, 4. Minas Gerais, Jan.-Fev. , 1983, p. 567-577.

PEREIRA, A. R. (1983). "Segurança do Trabalho na Empresa Florestal." In: Congresso Florestal Brasileiro, 4. Minas Gerais, Jan.-Fev. , 1983, p. 584-586.

PEREIRA, A.R.; Segurança do trabalho na empresa florestal. FLORESTA, Curitiba, 14(1): 24-28, Junho 1983.

REZENDE, J.L.P.; BARROS, A.A.A. e OLIVEIRA, A.D. Tratamento da inflação nos programas de investimentos florestais. ÁRVORE, Viçosa, 7(1): 44-55, Janeiro a Julho 1983.

REZENDE, J.L.P.; BARROS, A.A.A. e OLIVEIRA, A.D. Tratamento da inflação nos programas de investimentos florestais. ÁRVORE, Viçosa, 7(1): 44-55, Janeiro a Julho 1983.

1985: 1 trabalho

OLIVEIRA, I.M.V. e SEIXAS, F. Estudos da dieta balanceada para operador de moto-serra. IPEF, Piracicaba, (30): 19-27, Agosto 1985.

1986: 7 trabalhos

AOKI, H. (1986). "Sensoriamento Remoto aplicado à conservação dos recursos naturais renováveis." In:: Congresso Florestal Brasileiro, 5. Pernambuco, Novembro, 1986, p. 145. 
LISBÃO JÚNIOR, L . (1986). "Comparação entre dois métodos de avaliação e análise dos danos de geadas em mudas de E. viminalis Labell." In: Congresso Florestal Brasileiro, 5. Pernambuco, Novembro, 1986, p. 70.

MARCON, E. J. (1986). "Análise de óleo em equipamentos na Aracruz Florestal S. A. ." In: Congresso Florestal Brasileiro, 5. Pernambuco, Novembro, 1986, p. 135.

MARCON, E. J. (1986). "Controle de pneus na Aracruz Florestal S. A. ." In: Congresso Florestal Brasileiro, 5. Pernambuco, Novembro, 1986, p. 135.

OLIVEIRA, A.J. e COUTO, L. Simulação e comparação econômica das operações de reforma, densamento e interplantio em povoamentos de Eucalyptus, com utilização de sistema Manflor. IPEF, Piracicaba, (34): 63-67, Dezembro 1986.

REIS, M. G. F. e KIMMINS, J. P. (1986). "Métodos para Avaliação das Consequências do Manejo Intensivo na Produtividade Futura de Plantações e Eucalipto." In: Congresso Florestal Brasileiro, 5. Pernambuco, Novembro, 1986, p. 71.

SEIXAS, F. (1986). "Estudo de tempo em exploração florestal." In: Congresso Florestal Brasileiro, 5. Pernambuco, Novembro, 1986, p. 135.

1989: 1 trabalho

MACHADO, C.C. e MALINOVSKI, J.R. Desenvolvimento do sistema brasileiro de classificação de estradas florestais (SIBRACEF). ÁRVORE, Viçosa, 13(1): 114-129, Janeiro a Junho 1989.

1990: 12 trabalhos

BERGER, R. (1990). "Métodos de valoração de recursos florestais." In: Congresso Florestal Brasileiro, 6. , São Paulo, Setembro, 1990, p. 55-60.

CASSOL, R. Identificação e capacidade de descriminação do uso de terra, através da interpretação visual, entre as bandas espectrais do Tm Landsat 5. FLORESTA, Curitiba, 20(1/2): 66, Junho e Dezembro 1990.

GOMES, F. P. e GARCIA, C. H. (1990). "A interpretação econômica de um ensaio de adubação de $E$. grandis." In: Congresso Florestal Brasileiro, 6. , São Paulo, Setembro, 1990, p. 52-54.

GOMES, F.P. e GARCIA, C.H. A interpretação econômica de um ensaio de adubação de $E$. grandis. IPEF, Piracicaba, (43/44): 54-60, 1990.

JORGE, L.A.B.; VEIGA, R.A.A. e PONTINHA, A.A.S. A função Weibull no estudo de distribuição diamétrica em povoamentos de $P$. elliottii na extração experimental de Itapeva. IPEF, Piracicaba, (43/44): 54-60, 1990.

MACEDO, P. R. O. ; CASTRO, P. F. e RODRIGUES, A. V. (1990). "Sensibilidade econômico estratégica do uso de herbicidas em substituição à mão-de-obra rural junto a algumas atividades florestais em regiões acidentadas." In: Congresso Florestal Brasileiro, 6. , São Paulo, Setembro, 1990, p. 39-46. 
MENDONÇA FILHO, W. F. e PEREIRA, L. P. A. (1990). "Análise operacional de sistemas de abate mecanizado." In: Congresso Florestal Brasileiro, 6. , São Paulo, Setembro, 1990, p. 47-51.

OLIVEIRA, C.G. Análise de sistemas de informações nas empresas florestais do Estado do Paraná. FLORESTA, Curitiba, 20(1/2): 57-58, Junho e Dezembro 1990.

RIBAS, L.C. Estratégia econômica da reforma de povoamentos florestais de Pinus spp. FLORESTA, Curitiba, 20(1/2): 96-97, Junho e Dezembro 1990.

SMITH, E. B. S. ; LADEIRA, H. P. ; BARROS, A. A. A. e COUTO, L. (1990). "Determinação do prejuízo econômico para $E$. grandis (W. Hill ex Maiden) destinado à produção de carvão vegetal, resultante de sua exploração após a idade ótima de corte." In: Congresso Florestal Brasileiro, 6. , São Paulo, Setembro, 1990, p. 35-38.

TOZZINI, D.S. Avaliação de danos causados por incêndios florestais em $P$. taeda através de fotografias aérias e imagens de satelite. FLORESTA, Curitiba, 20(1/2): 26-27, Junho e Dezembro 1990.

VASQUES, A.G. Método de amostragem em linhas: desenvolvimento e aplicação em uma floresta implantada com P. taeda L. FLORESTA, Curitiba, 20(1/2): 79-80, Junho e Dezembro 1990.

1991: 2 trabalhos

DISPERATI, A.A. 0 uso do sensoriamento remoto no estudo de pragas florestais. FLORESTA, Curitiba, 21(1/2): 13-25, Junho e Dezembro 1991.

MACHADO, C.C. e SOUZA JÚNIOR, H.S. Otimização da produtividade e do custo do tombamento manual de toretes de madeira em regiões montanhosas. ÁRVORE, Viçosa, 15(2): 164-172, Junho a Dezembro 1991.

1992: 2 trabalhos

REZENDE, J.L.P.; SILVA, A.A.L. e PAULA JƯNIOR, G.G. Análise econômica da substituição de povoamentos de eucaliptos - caso do ciclo terminal. ÁRVORE, Viçosa, 16(3): 301-308, Setembro a Dezembro 1992.

SCOLFORO, J.R.S. e HOSOKAWA, R.T. Avaliação da rotação econômica para Pinus caribaea var.

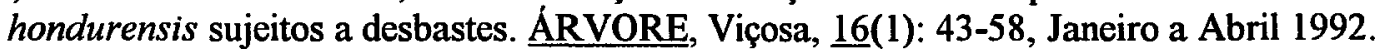

1993: 7 trabalhos

CARNIERI, C. e SCOLFORO, R. S. (1993). "O algorítimo gub como elemento de viabilização do processo de otimização de planos de manejo." In: Congresso Florestal Brasileiro, 7. , Paraná, Setembro, 1993, p. 531-534.

CARNIERI, C. (1993) "Técnicas de Otimização para Tomadas de Decisão em Manejo Florestal." In: Congresso Florestal Panamericano/Congresso Florestal Brasileiro, 1./7., p. 264, Curitiba, Paraná, 19 a 24 de Setembro, 1993. 
DONATI, Z. A. e ROLDI, L. M. (1993). "Treinamento operacional em atividades de colheta e transporte de madeira: a experiência de Aracruz." In: Congresso Florestal Brasileiro, 7. , Paraná, Setembro, 1993, p. 688-692.

REZENDE, J.L.P.; LOPES, H.V.S.; PAULA JÚNIOR, G.G. e NEVES, A.R. Efeito da taxa real de desconto sobre a idade ótima de corte de povoamentos de eucalipto, no Estado de Minas Gerais. ÁRVORE, Viçosa, 17(3): 339-350, Setembro a Dezembro 1993.

SCOLFORO, J. R. S. (1993). "Simulação de desbastes seletivos através de modelo matemático." In: Congresso Florestal Brasileiro, 7. , Paraná, Setembro, 1993, p. 549-552.

SEIXAS, F. e WIDMER, J.A. Seleção e dimensionamento da frota de veículos rodoviários para o transporte principal de madeira utilizando-se de programação linear não inteira. IPEF, Piracicaba, (46): 107-118, 1993.

VOLPATO, C. E. S. ; MACHADO, C. C. e SOUZA, A. P. (1993). "Estudo de tempo e movimento em uma operação de extração florestal com guincho - arrastado." In: Congresso Florestal Brasileiro, 7. , Paraná, Setembro, 1993, p. 679-681.

1994: 2 trabalhos

REZENDE, J.L.P.; SILVA, A.A.L.; PAULA JÚNIOR, G.G. e VALE, A.B. Análise econômica da substituição de povoamentos de Eucalyptus spp. - cadeias de substituições. ÁRVORE, Viçosa, 18(1): 56-62, Janeiro a Abril 1994.

REZENDE, J.L.P.; LOPES, H.V.S.; NEVES, A.R. e PAULA JÚNIOR, G.G. A importância do custo da terra na determinação da idade ótima de corte de povoamentos de eucalipto. ÁRVORE, Viçosa, 18(1): 45-55, Janeiro a Abril 1994.

\section{3) Informática}

1973: 1 trabalho

SOARES, R.V. Aplicações do modelo de programação linear na solução de problemas florestais. FLORESTA, Curitiba, $\underline{4}(2): 38-48,1973$.

1976: 1 trabalho

HOSOKAWA, R.T. A simulação como instrumental de planejamento florestal. FLORESTA, Curitiba, Z(1): 16-24, 1976.

1977: 2 trabalhos

BRUM, E.T.; ABREU, P.S.C. e OLIVEIRA, Y.M.M. Utilidade da rede PERT/CPM no setor florestal. FLORESTA, Curitiba, $\underline{8}(2): 33-46,1977$.

HOSOKAWA, R.T. Aplicação de computadores na estimativa dos custos de máquinas florestais. FLORESTA, Curitiba, $\underline{8}(2): 31-32,1977$. 
DISPERATI, A.A Aplicação de métodos computadorizados em mapeamento florestal. FLORESTA, Curitiba, 12(2): 13-22, Dezembro 1981.

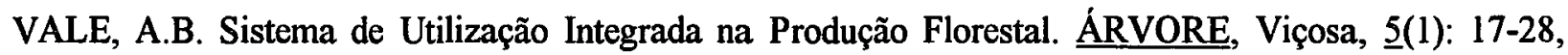
Janeiro a Junho 1981.

1983: 2 trabalhos

FERREIRA, R.; SALTON, A.; MESQUITA, J. e BRAIBANTE, J.A.S. (1983) "Planejamento Florestal através do Computador." In: Congresso Florestal Brasileiro, 4., p. 632, Minas Gerais, Jan.Fev., 1983.

RIBEIRO, R. A. S. (1983). "Sistema Automatizado para Processamento de Dados de Inventário Florestal para a Região Amazônica - Invet." In: Congresso Florestal Brasileiro, 4. Minas Gerais, Jan.-Fev. , 1983, p. 690-694.

1985: 1 trabalho

RODRIGUEZ, L.C.F. e LIMA, A.B.N.P.M. A utilização de programação linear na determinação de uma estratégia ótima de reforma de um talhas florestal. IPEF, Piracicaba, (31): 47-53, Dezembro 1985.

1986: 3 trabalhos

COUTO, L. ; RIBEIRO , J. C. ; LORENZONI, R. A. ; TORQUATO, M. C. e MONTEIRO, W. A. (1986). "Desenvolvimento de um sistema computacional para simular e comparar economicamente a localização de praças de fornos em áreas de reflorestamento e carvoejamento de eucalipto." In: Congresso Florestal Brasileiro, 5. Pernambuco, Novembro, 1986, p. 171.

COUTO, L. ; RIBEIRO, J. C. ; OLIVEIRA, A. J. ; SUITTER FILHO, W. e REZENDE, G. C. (1986). "Desenvolvimento de um sistema computacional para simular e comparar economicamente as operações de reforma, adensamento e interplantio em povoamentos de eucaliptos." In: Congresso Florestal Brasileiro, 5. Pernambuco, Novembro, 1986, p. 171.

RODRIGUEZ, L. C. E. ; LIMA, A. B. N. P. M. ; BUENO, A. C. e MARTINI, E. L. (1986). "Programação Linear no planejamento florestal: uma aplicação prática." In: Congresso Florestal Brasileiro, 5. Pernambuco, Novembro, 1986, p. 163.

1989: 1 trabalho

COUTO, H.T.Z.; BASTOS, N.L.M. e LACERDA, J.S. Comparação de dois modelos de prognose de madeira de Eucalyptus para alto fuste e talhadia. IPEF, Piracicaba, (41/42): 27-35, 1989.

1990: 1 trabalho

MENDES, J.B. Desenvolvimento de um sistema de inventário florestal por computador. FLORESTA, Curitiba, 20(1/2): 70-71, Junho e Dezembro 1990. 


\section{APÊNDICE B - Evolução da Produtividade na Silvicultura Brasileira}

As variações determinadas pelos diferentes ambientes, diferentes materiais genéticos e diferentes níveis tecnológicos, aliados às diferenças nas épocas consideradas na determinação da produtividade, dificultam mas não impedem o cálculo de níveis médios de produtividade para o eucalipto e para o pinus nas diferentes fases da evolução da silvicultura brasileira.

Em toda primeira metade do atual século, houve muito pouco em termos de aumentos de produtividade para as espécies de eucalipto e pinus, pois poucas foram as inovações tecnológicas nesse período.

Em 1960, segundo TOLEDO (1994), a produtividade média apresentada pelas áreas reflorestadas com eucalipto era de 10 a 15 estéreos/hectare/ano.

Já em 1968, de acordo com LEITE (1979), os melhores rendimentos das florestas de eucalipto estavam em torno de 15 a 20 estéreos/hectare/ano. Para este mesmo ano, a revista SILVICULTURA (1977) mostra que a produtividade média das área reflorestadas com eucalipto, no Brasil, estava em torno de 20 estéreos/hectare/ano. Ainda sobre o eucalipto, TOLEDO (1994) menciona incrementos médios de 17 a 26,7 estéreos/hectare/ano no período de 1967 a 1971.

GARLIPP (1982) considera para o eucalipto, até o ano de 1971, produtividades de 19,6 estéreos/hectare/ano para São Paulo, 9,7 estéreos/hectare/ano para o Mato Grosso do Sul e 7,3 estéreos/hectare/ano para o Triângulo Mineiro.

VICTOR et alii (1972), adotando um ciclo de 25 anos para pinus, assumiu rendimento médio de 22 estéreos/hectare/ano para as espécies deste gênero, isto em 1972.

TOLEDO (1994), para o período de 1972 a 1977, diz que houve um incremento médio para o eucalipto na faixa de 26,7 estéreos/hectare/ano.

GARLIPP (1982), para o intervalo de tempo entre os anos de 1972 e 1975, considera uma produtividade média para o eucalipto de 21,7 estéreos/hectare/ano para São Paulo, 12,3 estéreos/hectare/ano para o Mato Grosso do Sul e 11,0 estéreos/hectare/ano para o Triângulo Mineiro. 
Segundo a revista SILVICULTURA (1977), em 1975, já havia resultados de produtividade do eucalipto em torno de 35 estéreos/hectare/ano.

Nos ANAIS DO IV ENCONTRO NACIONAL DE REFLORESTADORES (1978), encontramos dados que mostram que, no ano de 1978, eram consideradas produtividades de 37 estéreos/hectare/ano para o Pinus caribaea var. hondurensis e 29 estéreos/hectare/ano para o Pinus caribaea var. caribaea e para o Pinus oocarpa.

Conforme GARLIPP (1982), devia-se considerar, para o período de 1976 a 1984, para o eucalipto, produtividades médias de 30,5 estéreos/hectare/ano para o Estado de São Paulo, 15,3 estéreos/hectare/ano para o Estado de Mato Grosso do Sul e 14,2 estéreos/hectare/ano para o Triângulo Mineiro.

GARLIPP (1982) também cita BEATTIE e FERREIRA (1978)' dizendo que estes autores, diante da elevada desuniformidade referente às taxas de crescimento, optaram, em seu trabalho, por estabelecer, para o ano de 1978, três níveis de produtividade para o eucalipto: 39,$2 ; 33,5$, e 27,9 estéreos/hectare/ano para os cortes realizados aos 7,12 e 17 anos.

Quanto ao pinus, GARLIPP (1982), para o ano de 1982, fala num incremento médio anual de 15,32 estéreos/hectare/ano.

De acordo com a EMBRAPA-RELATÓRIO DE ATIVIDADES (1983-1984), em 1983, a produtividade média apresentada pelas áreas reflorestadas com espécies de eucalipto era de 35 estéreos/hectare/ano e a produtividade média das áreas reflorestadas com espécies de pinus era de 25 estéreos/hectare/ano.

Segundo médias aritméticas apresentadas por associações e empresas, no ano de 1988, falava-se em níveis de produtividade para o eucalipto de 40 estéreos/hectare/ano para o Estado de São Paulo, 48 estéreos/hectare/ano para o Paraná, 45 estéreos /hectare/ano para o Rio Grande do Sul e 60 estéreos/hectare/ano para o Espírito Santo. Já para o gênero pinus, neste mesmo ano, falava-se em níveis de produtividade de 30 estéreos/hectare/ano para as espécies de origem tropical e 35 estéreos/hectare/ano para as espécies de origem subtropical.

1 BEATTIE, S.D. \& FERREIRA, J.M. (1978). Análise financeira e sócio-econômica do reflorestamento no Brasil. Brasília, IBDF/COPLAN, 158p. . 
RATTNER et alii (1993) dizem que em 1988, em florestas tecnicamente conduzidas, podia-se obter incrementos de 60 estéreos/hectare/ano para espécies de eucalipto.

De acordo com dados de empresas consultadas, a produtividade média do eucalipto, no ano de 1989, era de 55 estéreos/hectare/ano e a produtividade média do pinus, no mesmo ano, era de 33 estéreos/hectares/ano. TOLEDO (1994) confirma estes dados dizendo que no final da década de 80 , o nível tecnológico atingido já permitia a obtenção, em algumas áreas, de incrementos superiores a 53 estéreos/hectare/ano para as espécies de eucalipto. Ainda segundo TOLEDO (1994), para o início da década de noventa, o que havia, em geral, era uma produtividade média de 42 estéreos/hectare/ano para as espécies de eucalipto.

Segundo média de algumas empresas consultadas, a produtividade média do eucalipto esteve em torno de 55 estéreos/hectare/ano em 1990 e em 1991, 43 estéreos/hectare/ano em 1992, 50 estéreos/hectare/ano em 1993 e 60 estéreos/hectare/ano em 1994. Já quanto ao pinus, obtemos a informação de que a produtividade média esteve em torno de 33 estéreos/hectare/ano em 1990 e 1991, 26 estéreos/hectare/ano em 1992 e 32 estéreos/hectare/ano em 1993 e 1994.

Conforme RATTNER et alii (1993), na década de noventa, a produtividade média das espécies de eucalipto esteve na faixa de 47 a 67 estéreos/hectare/ano, com alguns produtores do setor de papel e celulose alcançando médias entre 93 e 133 estéreos/hectare/ano.

Segundo dados da ASSOCIAÇÃO NACIONAL DOS FABRICANTES DE PAPEL E CELULOSE (1991), a ANFPC, no ano de 1991, a produtividade média apresentada pelas áreas reflorestadas com espécies de eucalipto estava em torno de 46 estéreos/hectare/ano e a produtividade média apresentada pelas áreas reflorestadas com espécies de pinus estava em torno de 35 estéreos/hectare/ano.

Segundo a ANFPC (1992), no ano de 1992, a produtividade média das florestas plantadas era 43 estéreos/hectare/ano para as espécies de eucalipto e 33 estéreos/hectare/ano para as espécies de pinus. 
Para o ano de 1993, a produtividade média das florestas plantadas com eucalipto era 43 estéreos/hectare/ano e a produtividade média das florestas plantadas com pinus era 34 estéreos/hectare/ano (ANFPC, 1993).

De acordo com RATTNER et alii (1993), ensaios experimentais indicam que até o final da década de noventa, a produtividade de florestas comerciais poderá alcançar níveis que vão de 200 estéreos/hectare/ano a 267 estéreos/hectare/ano, no primeiro corte, já aos 5 anos.

Diante dessa ampla variedade de dados, consideramos os valores mais coerentes das fontes mais confiáveis, constituindo o seguinte quadro de valores para as produtividades do eucalipto e do pinus: 


\begin{tabular}{|c|c|c|c|c|}
\hline Ano & $\begin{array}{c}\text { Produtividade } \\
\text { eucalipto } \\
\text { (st/ha/ano) }\end{array}$ & Autor & $\begin{array}{l}\text { Produtividade } \\
\text { Pinus } \\
\text { (st/ha/ano) }\end{array}$ & Autor \\
\hline 1960 & 12,50 & $\begin{array}{l}\text { Média segundo } \\
\text { TOLEDO(1994) }\end{array}$ & & \\
\hline 1967 & 17,00 & $\begin{array}{c}\text { Menor valor } \\
\text { segundo } \\
\text { TOLEDO(1994) }\end{array}$ & & \\
\hline 1968 & 17,50 & $\begin{array}{l}\text { Média segundo } \\
\text { LEITE(1969) }\end{array}$ & 20,00 & $\begin{array}{l}\text { Média segundo } \\
\text { EMPRESAS } \\
\text { CONSULTADAS }\end{array}$ \\
\hline 1970 & & & 20,00 & $\begin{array}{l}\text { Média segundo } \\
\text { EMPRESAS } \\
\text { CONSULTADAS }\end{array}$ \\
\hline 1971 & 19,60 & $\begin{array}{l}\text { Valor referente a } \\
\text { SP segundo } \\
\text { GARLIPP(1982) }\end{array}$ & & \\
\hline 1972 & & & 22,00 & VICTOR(1972) \\
\hline 1975 & 21,70 & $\begin{array}{c}\text { Valor para SP } \\
\text { segundo } \\
\text { GARLIPP(1982) }\end{array}$ & & \\
\hline 1977 & 26,70 & TOLEDO(1994) & & \\
\hline 1978 & 27,90 & $\begin{array}{c}\text { Menor valor } \\
\text { segundo } \\
\text { BEATTIE e } \\
\text { FERREIRA(1982) }\end{array}$ & & \\
\hline 1983 & 35,00 & $\begin{array}{l}\text { EMBRAPA } \\
(1983-1984)\end{array}$ & 25,00 & $\begin{array}{l}\text { EMBRAPA } \\
(1983-1984)\end{array}$ \\
\hline 1988 & 40,00 & $\begin{array}{c}\text { EMPRESAS } \\
\text { CONSULTADAS } \\
\text { valor para SP }\end{array}$ & 32,50 & $\begin{array}{c}\text { Média segundo } \\
\text { EMPRESAS } \\
\text { CONSULTADAS }\end{array}$ \\
\hline 1990 & 42,00 & TOLEDO(1994) & & \\
\hline 1991 & 46,00 & ANFPC(1991) & 35,00 & ANFPC(1991) \\
\hline 1992 & 43,00 & ANFPC(1992) & 33,00 & ANFPC(1992) \\
\hline 1993 & 43,00 & ANFPC(1993) & 34,00 & ANFPC(1993) \\
\hline
\end{tabular}

FONTE: Vários Autores (Veja este Apêndice)

Tomando-se os dados acima e realizando interpolação para os anos não especificados, chegamos à Tabela 7 (item 3.2, capítulo 3). 


\section{APÊNDICE C - Custo do Reflorestamento/Florestamento}

Para analisar a influência exclusiva da variação dos preços reais dos insumos e dos fatores de produção sobre o custo do reflorestamento/florestamento, precisamos considerar um dado nível tecnológico para todo o período em questão, ou seja, precisamos considerar um mesmo sistema de produção para a silvicultura brasileira com níveis de produtividade constantes. Utilizando informações do III ENCONTRO NACIONAL DE REFLORESTADORES (1977), do IPEF-Circular Técnica no 14 (1977) e de BEATTIE e FERREIRA (1978), além dos quadros comparativos dos sistemas de produção do eucalipto e do pinus apresentados por nós (item 2.2, capítulo 2), obtivemos vários coeficientes técnicos que podem caracterizar tal sistema de produção.

No presente trabalho, com o propósito de estimar um custo específico e básico para a silvicultura brasileira, por julgá-los mais importantes, consideramos o seguinte: quantidade de terra (em hectares), quantidade de mão-de-obra (em homens/ano/hectare), quantidade de mudas (em número de mudas/hectare), quantidade de uso dos equipamentos (em horas de equipamento/ano/hectare), quantidade de defensivos (em quilogramas de formicida/ano/hectare) e quantidade de adubo (em quilogramas de uma formulação NPK/muda).

O Quadro $\mathrm{C} 1$ mostra os coeficientes técnicos bem como as quantidades totais de insumos e fatores de produção utilizadas no ciclo total da cultura do eucalipto (gênero mais representativo da silvicultura brasileira e cujo sistema de produção é bastante semelhante ao do pinus). Foi considerado um ciclo produtivo de 20 anos, com 3 rotações, para caracterizar o período de 1969 a 1986. Foi, também, considerado um nível de produtividade fixo em torno de 25 estéreos/hectare/ano. 


\begin{tabular}{|c|c|c|c|c|}
\hline $\begin{array}{c}\text { Insumo/ } \\
\text { Fatores de produção }\end{array}$ & & $\begin{array}{l}\text { Coeficiente } \\
\text { Técnico }\end{array}$ & $\begin{array}{l}\text { Quantidade Total } \\
\text { (para } 20 \text { anos) }\end{array}$ & \\
\hline Terra & & 1 hectare (ha) & 1 hectare (ha) & \\
\hline Mão-de-obra & $\begin{array}{l}\text { plantio } \\
\text { manutenção } \\
\text { colheita }\end{array}$ & $\begin{array}{l}0,150 \text { homens/ha/ano } \\
0,002 \text { homens/ha/ano } \\
0,150 \text { homens/ha/ano }\end{array}$ & $\begin{array}{l}0,150 \text { homens/ha } \\
0,040 \text { homens/ha } \\
0,450 \text { homens/ha }\end{array}$ & 0,64 homens/ha \\
\hline Capital & equipamentos & 12,2 horas/ano/ha & \multicolumn{2}{|l|}{244 horas/ha } \\
\hline Insumos & $\begin{array}{l}\text { mudas } \\
\text { formicida } \\
\text { adubo (NPK) }\end{array}$ & $\begin{array}{l}1917 \text { mudas/ha } \\
1 \mathrm{~kg} / \mathrm{ano} / \mathrm{ha} \\
75 \text { gramas } / \text { muda }\end{array}$ & \multicolumn{2}{|l|}{$\begin{array}{l}1917 \text { mudas } / \mathrm{ha} \\
20 \mathrm{~kg} / \mathrm{ha} \\
144 \mathrm{~kg} / \mathrm{ha}\end{array}$} \\
\hline
\end{tabular}

FONTES: ENCONTRO NACIONAL DE REFLORESTADORES (1977)

IPEF - Circular Técnica no 14 (1977)

BEATTIE e FERREIRA (1978)

No Quadro C1, 1 homem/ano/hectare corresponde a 50 horas semanais de trabalho, 50 semanas por ano (BEATTIE e FERREIRA, 1978).

O ciclo produtivo de 20 anos adotado para a silvicultura brasileira para o período de 1969 a 1986 compreende 1 ano para a implantação da cultura, 20 anos de manutenção e 3 anos para as colheitas (10, 20 e 30 cortes). Assim, as quantidades totais para os diferentes tipos de mão-de-obra (plantio, manutenção e colheita), por exemplo, foram obtidas multiplicando-se os seus coeficientes técnicos pelas respectivas quantidades de anos em que são utilizadas. Para exemplificar, podemos mencionar a mão-de-obra de manutenção: coeficiente técnico (igual a 0,002 homens/ano/hectare) vezes a quantidade de anos (igual a 20 anos) resulta em 0,04 homens/hectare no ciclo total.

Para o cálculo da quantidade de mudas, considerando um espaçamento de $3 \times 2$ metros, obtivemos um número de 1667 mudas por hectare. Assumindo $15 \%$ para a prática do replantio, chegamos a um número de 1917 mudas por hectare.

No cálculo da quantidade total de horas de uso de equipamento/hectare, consideramos que há uma freqüência e uma constância neste uso, ou seja, 12,2 horas de equipamento/ano/hectare vezes 20 anos é igual a 244 horas/hectare.

No cálculo da quantidade total de defensivos, consideramos o uso exclusivo de formicida (isto devido à sua importância no período considerado) aplicado durante todo o 
ciclo produtivo $(1 \mathrm{~kg}$ de formicida/ano/hectare $\times 20$ anos $=20 \mathrm{~kg}$ de formicida/hectare, em 20 anos).

Para o cálculo da quantidade total de adubo, consideramos uma formulação de NPK com 33\% de Sulfato de Amônia, 62\% de Superfosfato de Cálcio Simples e 5\% de Cloreto de Potássio, sendo que esta mistura foi aplicada somente no ano de implantação (IPEF-Circular Técnica no 14, 1977).

$\mathrm{Na}$ Tabela $\mathrm{C} 1$, encontramos dados anuais para os preços pagos pelos agricultores (valores em Dólares de Dezembro de 1992) para o arrendamento de terra, mão-de-obra (salário rural), mudas, horas de uso de equipamentos, defensivos (formicida) e adubo (uma fórmula com Sulfato de Amônia, Superfosfato de Cálcio Simples e Cloreto de Potássio). Estes preços são representativos do Brasil como um todo. 
TABELA C1 - PREÇOS PAGOS PELOS AGRICULTORES PELO ARRENDAMENTO DA TERRA, MÃO-DE-OBRA (SALÁRIO RURAL), MUdAS, HORAS DE USO DE EQUIPAMENTOS, DEFENSIVOS (FORMICIDA) E ADUBO. Valores em Dólares de Dezembro de 1992.

\begin{tabular}{c|c|c|c|c|c|c}
\hline Ano & $\begin{array}{c}\text { Arrendamento } \\
\text { da terra } \\
\text { (US\$/ha/ano) }\end{array}$ & $\begin{array}{c}\text { Salário } \\
\text { Rural } \\
\text { (US\$/ano) }\end{array}$ & $\begin{array}{c}\text { Mudas } \\
\text { (US\$/unid.) }\end{array}$ & $\begin{array}{c}\text { Horas de } \\
\text { equipamento } \\
\text { (US\$/hora) }\end{array}$ & $\begin{array}{c}\text { Formicida } \\
\text { (US\$/kg) }\end{array}$ & $\begin{array}{c}\text { Adubo } \\
\text { (US\$/kg) }\end{array}$ \\
\hline 1969 & 61,36 & $1.681,60$ & 0.06 & 4,73 & 1,98 & 0,26 \\
1970 & 72,27 & $1.429,62$ & 0,08 & 4,77 & 1,86 & 0,24 \\
1971 & 81,44 & $1.448,50$ & 0,07 & 4,56 & 1,74 & 0,22 \\
1972 & 106,01 & $1.464,44$ & 0,07 & 4,42 & 1,65 & 0,23 \\
1973 & 134,87 & $1.542,62$ & 0,08 & 4,51 & 1,68 & 0,25 \\
1974 & 160,50 & $1.589,06$ & 0,10 & 4,31 & 1,90 & 0,49 \\
1975 & 161,67 & $1.662,41$ & 0,10 & 4,67 & 1,68 & 0,53 \\
1976 & 151,00 & $1.634,58$ & 0,09 & 4,04 & 1,60 & 0,35 \\
1977 & 138,29 & $1.769,81$ & 0,08 & 3,90 & 1,58 & 0,31 \\
1978 & 136,77 & $1.890,53$ & 0,10 & 4,32 & 1,59 & 0,31 \\
1979 & 136,93 & $1.970,44$ & 0,07 & 3,84 & 1,50 & 0,30 \\
1980 & 143,02 & $1.897,65$ & 0,08 & 3,40 & 1,69 & 0,38 \\
1981 & 147,55 & $1.695,22$ & 0,06 & 4,01 & 1,95 & 0,39 \\
1982 & 145,16 & $1.736,89$ & 0,04 & 4,39 & 1,77 & 0,35 \\
1983 & 136,99 & $1.532,30$ & 0,04 & 3,71 & 1,52 & 0,33 \\
1984 & 145,06 & $1.375,64$ & 0,03 & 4,07 & 2,05 & 0,39 \\
1985 & 155,36 & $1.627,12$ & 0,03 & 4,92 & 1,97 & 0,40 \\
1986 & 178,59 & $1.531,19$ & 0,12 & 3,68 & 2,06 & 0,30 \\
\hline
\end{tabular}

FONTES: (1) e (2) - ANUÁRIO ESTATÍSTICO DO BRASIL (1972, 1975, 1977, $1980,1985,1987 / 88)$.

(3), (4), (5) e (6) - PREÇOS PAGOS PELOS AGRICULTORES $(1970 / 1974,1974 / 1979,1980 / 1981,1982 / 1983,1984 / 1985)$.

$\mathrm{Na}$ construção da Tabela $\mathrm{Cl}$, devido à ausência de dados para o Brasil como um todo dos preços pagos pelos agricultores pelo arrendamento da terra para o período de 1970 a 1973 e 1986, optamos por considerar valores referentes ao Estado de São Paulo (dados da revista INFORMAÇÕES ESTATÍSTICAS DA AGRICULTURA, 1992). Estes valores, contudo, foram reduzidos em $10 \%$ para ajustarem-se às médias brasileiras dos respectivos anos em questão.

\footnotetext{
${ }^{1}$ Esta percentagem foi obtida da comparação dos valores dos anos onde há dados tanto para os preços pagos pelos agricultores pelo arrendamento da terra para o Brasil quanto para o Estado de São Paulo.
} 
De acordo com a revista INFORMAÇõES ECONÔMICAS, anos de 1990 a 1995, calculamos os preços pagos pelos agricultores pela hora de uso de equipamento como sendo $0,027 \%$ do preço de um trator novo (trator médio, segmento de 36 a $45 \mathrm{HP}$ de potência) ${ }^{2}$.

Os preços pagos pelo adubo (em Dólares $/ \mathrm{kg}$ ) foram calculados pegando-se $33 \%$ do preço pago pelos agricultores pelo quilograma $(\mathrm{kg})$ de Sulfato de Amônia, 62\% do preço do quilograma de Superfosfato de Cálcio Simples e $5 \%$ do preço pago pelo quilograma de Cloreto de Potássio.

Uma vez conhecidos as quantidades totais de insumos e fatores de produção básicos necessários à implantação, manutenção e exploração de uma cultura florestal (Quadro C1) - no caso, eucalipto - e os preços anuais pagos pelos agricultores por esses insumos e fatores de produção (Tabela C1), na Tabela C2, apresentamos os custos de produção correspondentes a cada um desses insumos e fatores de produção bem como a soma desses custos, ou seja, o nosso custo total do reflorestamento/florestamento para um sistema de produção fixo, sem incorporação de inovações tecnológicas e sem variações nos níveis de produtividade. Este custo é para todo um ciclo. Definida uma produtividade, teremos um custo por estéreo.

\footnotetext{
${ }^{2}$ Esta percentagem foi obtida da comparação dos valores dos anos onde há dados tanto para o preço dos tratores quanto para o preço pago pelos agricultores pela hora de uso de equipamento.
} 
TABELA C2 - CUSTO DO ARRENDAMENTO DA TERRA (1), CUSTO DA MÃODE-OBRA (2), CUSTO DE MUDAS (3), CUSTO DO USO DE EQUIPAMENTOS (4), CUSTO DE FORMICIDA (5), CUSTO DE $\begin{array}{llllll}\text { ADUBO } & \text { NPK } & (6) & \text { E } & \text { CUSTO } & \text { DO }\end{array}$ REFLORESTAMENTO/FLORESTAMENTO $(1+2+3+4+5+6)$. Valores em Dólares de Dezembro de 1992, para 1 hectare, período 1969 a 1986.

\begin{tabular}{l|l|r|r|r|r|r|r}
\hline Ano & $\begin{array}{l}\text { Arrenda- } \\
\text { mento da } \\
\text { terra }\end{array}$ & Mão-de-obra & Mudas & $\begin{array}{c}\text { Uso de } \\
\text { equipamento }\end{array}$ & Formicida & Adubo & $\begin{array}{c}\text { Total (Custo } \\
\text { do Reflores- } \\
\text { tamento/Flo- } \\
\text { restamento) }\end{array}$ \\
\hline 1969 & $1.227,20$ & $1.076,22$ & 115,02 & $1.154,12$ & 39,60 & 37,44 & $3.648,60$ \\
1970 & $1.445,40$ & 914,96 & 153,36 & $1.163,88$ & 37,20 & 34,56 & $3.749,36$ \\
1971 & $1.628,80$ & 927,04 & 134,19 & $1.112,64$ & 34,80 & 31,68 & $3.869,15$ \\
1972 & $2.120,20$ & 937,24 & 134,19 & $1.078,48$ & 33,00 & 33,12 & $4.336,23$ \\
1973 & $2.697,40$ & 987,28 & 153,36 & $1.100,44$ & 33,60 & 36,00 & $5.008,08$ \\
1974 & $3.210,00$ & $1.017,00$ & 191,70 & $1.054,08$ & 38,00 & 70,56 & $5.581,34$ \\
1975 & $3.233,40$ & $1.063,94$ & 191,70 & $1.139,48$ & 33,60 & 76,32 & $5.738,44$ \\
1976 & $3.020,00$ & $1.046,13$ & 172,53 & 985,76 & 32,00 & 50,40 & $5.306,82$ \\
1977 & $2.765,80$ & $1.132,68$ & 153,36 & 951,60 & 31,60 & 44,64 & $5.079,68$ \\
1978 & $2.735,40$ & $1.209,94$ & 191,70 & $1.054,08$ & 31,80 & 44,64 & $5.267,56$ \\
1979 & $2.738,60$ & $1.261,08$ & 134,19 & 936,96 & 30,00 & 43,20 & $5.144,03$ \\
1980 & $2.860,40$ & $1.214,50$ & 153,36 & 829,60 & 33,80 & 54,72 & $5.146,38$ \\
1981 & $2.951,00$ & $1.084,94$ & 115,02 & 978,44 & 39,00 & 56,16 & $5.224,56$ \\
1982 & $2.903,20$ & $1.111,61$ & 76,68 & $1.071,16$ & 35,40 & 50,40 & $5.248,45$ \\
1983 & $2.739,80$ & 980,67 & 76,68 & 905,24 & 30,40 & 47,52 & $4.780,31$ \\
1984 & $2.901,20$ & 880,41 & 57,51 & 993,08 & 41,00 & 56,16 & $4.929,36$ \\
1985 & $3.107,20$ & $1.041,36$ & 57,51 & $1.200,48$ & 39,40 & 57,60 & $5.503,55$ \\
1986 & $3.571,80$ & 979,96 & 230,04 & 897,92 & 41,20 & 43,20 & $5.764,12$ \\
\hline
\end{tabular}

FONTES: QUADRO C1

TABELA C1 
Para o conjunto de regressões estimadas para as empresas de papel e celulose, usamos o mesmo procedimento anteriores, cujos valores encontram-se na Tabela C3.

TABELA C3 - CUSTO DO ARRENDAMENTO DA TERRA (1), CUSTO DA MÃO-DE-OBRA (2), CUSTO DE MUDAS (3), CUSTO DO USO DE EQUIPAMENTOS (4), CUSTO DE FORMICIDA (5), CUSTO DE $\begin{array}{llllll}\text { ADUBO } & \text { NPK } & (6) & E & \text { CUSTO } & \text { DO }\end{array}$ REFLORESTAMENTO/FLORESTAMENTO(1+2+3+4+5+6).Valore $s$ em Dólares de Dezembro de 1992 e para 1 hectare.

\begin{tabular}{c|c|r|r|r|r|r|c}
\hline Ano & $\begin{array}{c}\text { Arrenda- } \\
\text { mento da } \\
\text { terra }\end{array}$ & Mão-de-obra & Mudas & $\begin{array}{c}\text { Uso de } \\
\text { equipamento }\end{array}$ & Formicida & Adubo & $\begin{array}{c}\text { Total (Custo } \\
\text { do Reflores- } \\
\text { tamento/Flo- } \\
\text { restamento) }\end{array}$ \\
\hline 1981 & $3.852,60$ & $1.196,19$ & 76,68 & $1.102,88$ & 39,00 & 60,48 & $6.327,83$ \\
1982 & $3.341,00$ & $1.385,09$ & 90,10 & $1.444,48$ & 35,40 & 53,28 & $6.349,35$ \\
1983 & $2.879,60$ & $1.098,05$ & 69,01 & $1.305,40$ & 51,20 & 61,92 & $5.465,18$ \\
1984 & $3.526,20$ & 992,79 & 49,84 & $1.166,32$ & 53,40 & 60,48 & $5.849,03$ \\
1985 & $4.211,00$ & $1.150,57$ & 49,84 & $1.193,16$ & 41,80 & 59,04 & $6.705,41$ \\
1986 & $3.968,60$ & $1.143,65$ & 230,04 & 727,12 & 25,40 & 33,12 & $6.127,93$ \\
1987 & $3.165,60$ & 918,57 & 45,93 & $1.451,80$ & 32,80 & 51,84 & $5.666,54$ \\
1988 & $3.707,80$ & 840,99 & 42,05 & $1.756,80$ & 29,20 & 57,60 & $6.434,44$ \\
1989 & $3.648,80$ & 993,04 & 49,65 & $1.898,32$ & 35,10 & 57,60 & $6.682,51$ \\
1990 & $3.299,40$ & 785,61 & 39,28 & $1.525,00$ & 53,00 & 41,76 & $5.744,05$ \\
1991 & $2.973,60$ & 764,61 & 38,23 & 207,40 & 22,20 & 33,12 & $4.039,16$ \\
1992 & $3.261,80$ & 596,58 & 97,76 & 207,40 & 30,20 & 21,60 & $4.215,34$ \\
\hline
\end{tabular}

FONTES: Série Informações Estatísticas da Agricultura (1992 e 1993)

Preços Pagos Pelos Agricultores (1981 a 1992)

Informações Econômicas (1981 a 1992)

Florestar Estatístico (1992) 


\section{APÊNDICE D - Teste da Equação da Área Reflorestada/Florestada para todo o Brasil}

Testamos, pelo Método dos Mínimos Quadrados Ordinários, a seguinte equação:

$A_{t}=B_{0}+B_{1} P_{t-k}+B_{2} I_{t}+B_{3} P_{t-k}+B_{4} C_{t-k}+B_{5} A_{t-k}$

Onde esperamos ser $B_{1}>0, B_{2}>0, B_{3}>0, B_{4}<0$ e $B_{5}>0$.

As equações obtidas são apresentadas a seguir.

Os valores entre parênteses sob os coeficientes estimados referem-se à estatística t. Além disso,

* indica o coeficiente ser estatisticamente significativo a $0,05 \%$;

** indica o coeficiente ser estatisticamente significativo a $1 \%$; indica o coeficiente ser estatisticamente significativo a 5\%;

$* * * *$ indica o coeficiente ser estatisticamente significativo a $10 \%$;

$* * * * *$ indica o coeficiente ser estatisticamente significativo a $20 \%$. 


\section{ÁREA TOTAL}

\section{Utilizando valores anuais e variáveis defasadas em 1 ano (exceto $I_{\mathfrak{t}}$ ):}

$$
\begin{aligned}
& \text { 19) } A_{t}=-55371,71+46439,46 P_{t-1}+161,35 I_{t}+111571,3 \mathrm{Dt}+5130,703 \mathrm{Pr}_{t-1}-4,1548 C_{t-1}-0,1248 A_{t-1} \\
& R^{2}=0,74283889 \quad n=17 \quad F=5,522293 \quad h=n a ̃ o \text { é calculável } \\
& \text { 2吕 } A_{t}=-25645,27+41288,58 P_{t-1}+149,1091 I_{t}+119165,4 D t+4020,355 P_{t-1}-6,06 C_{t-1} \\
& \begin{array}{cccc}
(-0,1925387) & (1,539951) & (1,772999) * * * * & (1,768194)^{* * * *} \quad(0,744675 \\
R^{2}=0,73761753 & n=17 & F=7,387327 & D W=2,33906247
\end{array} \\
& \text { 3) } A_{t}=-26201,67+38580,75 P^{P}{ }_{t-1}+149,63 I_{t}+115731,5 D t+3480,015 \operatorname{Pr}_{t-1} \\
& R^{2}=0,73721918 \quad n=17 \quad F=10,72285^{* *} \quad D W=2,32574919
\end{aligned}
$$

\section{Utilizando logaritmos neperianos na situação anterior:}

4- ${ }^{2} \operatorname{Ln}_{t}=12,759+0,7689 \operatorname{LnP}^{P}{ }_{t-1}+0,25 \operatorname{LnI}_{t}+0,359929 \mathrm{Dt}+0,363 \operatorname{LnPr}_{t-1}-0,1319 C_{t-1}-0,2273 \operatorname{Ln} A_{t-1}$

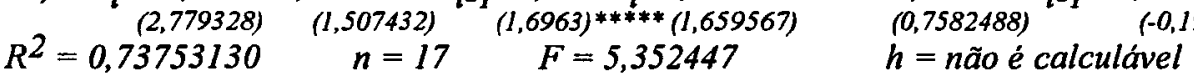

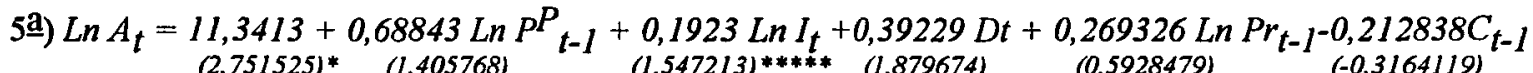
$R^{2}=0,72211280 \quad n=17 \quad F=6,798685^{* *} \quad D W=2,52434296$

6의 $\operatorname{Ln} A_{t}=10,07443+0,583343 \operatorname{Ln} P_{t-1}+0,1896574 L n I_{t}+0,365647 D t+0,1633157 L n P_{t-1}$

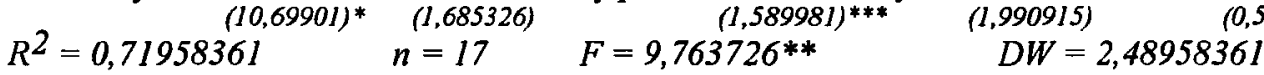

\section{Utilizando média móvel anual para as variáveis $P^{P}$ e $C(t$ e t-1):}

$$
\begin{aligned}
& \text { 7a) } A_{t}=6145,466+8118,14 P_{t, t-1}+189,2588 I_{t}+799841,7 D t-1205,889 P r_{t-1}+47,7117 C_{t, t-1}+0,0293 A_{t-1} \\
& R^{2}=0,70651180^{(0,02919)(0,1753819)} \quad n=17 \quad F=4,591206 \quad(-0,1183667) \quad(0,72) \quad h=0,5849054 \\
& \left.8^{\underline{\mathrm{a}}}\right) A_{t}=-4005,72+10385,15 P^{P} t, t-1+189,85 I_{t}+78267,45 D t-669,64 P_{t-1}+46,32 C_{t, t-1}
\end{aligned}
$$

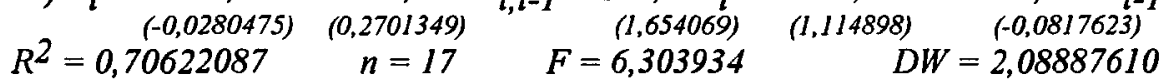

\section{Utilizando logaritmos neperianos na situação anterior}

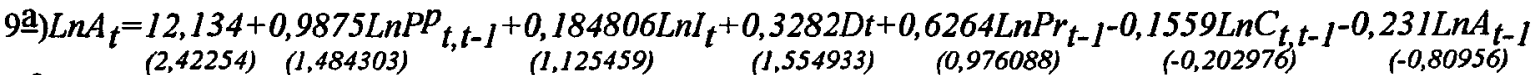

$$
\begin{aligned}
& R^{2}=0,75086343 \quad n=17 \quad F=5,745873 \quad h=\text { não é calculável } \\
& \text { 10a) } \operatorname{Ln} A_{t}=10,40874+0,869203 \operatorname{LnP}^{P}{ }_{t, t-1}+0,1284114 \operatorname{Ln} I_{t}+0,359 D t+0,4794 \operatorname{Ln} P_{t-1}-0,174582 C_{t, t-1}
\end{aligned}
$$

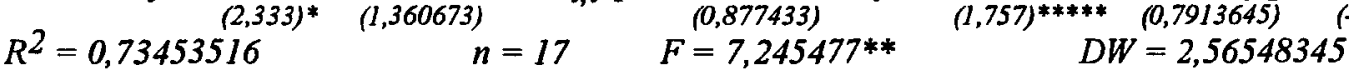


11 $\left.{ }^{\mathrm{a}}\right) \operatorname{Ln} A_{t}=9,416936+0,7609426 \operatorname{Ln} P^{P} t_{t, t-1}+0,1364577 \operatorname{Ln~}_{t}+0,3387579 \mathrm{Dt}+0,3631191 \mathrm{Ln} \mathrm{Pr}_{t-1}$ $\begin{array}{cccr}R^{2}=0,73324676 & n=17 & F=10,46865^{* *} & D W=2,51536282\end{array}$

\section{Utilizando média móvel bianual para as variáveis $P P, C$ (t e t-1) e Pr (t-1 e t-2):}

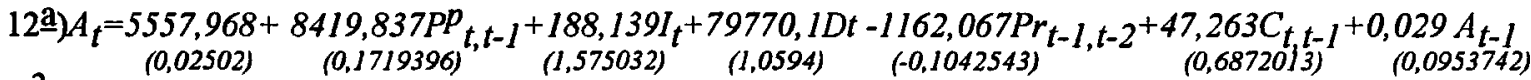

$$
\begin{aligned}
& R^{2}=0,70641969 \quad n=17 \quad F=4,589138 \quad h=-0,0598824
\end{aligned}
$$

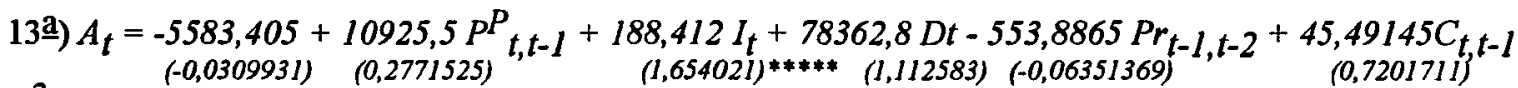

$$
\begin{aligned}
& R^{2}=0,70641969 \quad n=17 \quad F=6,301832 * * \quad D W=2,51262939 \\
& \text { 14吕) } A_{t}=-42218,92+35318,73 P_{t, t-1}+149,3893 I_{t}+98082,95 D t+4909,313 P r_{t-1, t-2} \\
& \begin{array}{clccc}
(-0,2493487) & (1,78754) * * * * & (1,521764) & (1,542727) & (1,164861 \\
R^{2}=0,69229784 & n=17 \quad F=8,573466 * * & D W=2,28087694
\end{array}
\end{aligned}
$$

\section{ÁREA EUCALIPTO + PINUS}

\section{Utilizando valores anuais e variáveis defasadas em 1 ano (exceto $I_{t}$ ):}

1. Aep $=123.314,9+31.216,66 P_{t-1}+21,8579 I_{t}+70937,47 D t+662,9829 P_{t-1}-28,41675 C_{t-1}+0,108 A^{2 e p} t-1$

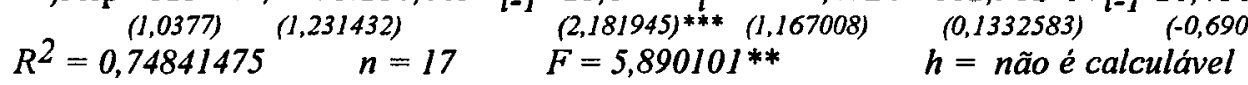

2吕) $\mathrm{Aep}=113.627,8+35.194,68 P_{t-1}^{P}+23,49815 I_{t}+64.788,29 \mathrm{Dt}+1.308,173 P_{t-1}-29,31696 C_{t-1}$

$\begin{array}{cccccc}(1,0142) & (1,559862) & (2,655201)^{* * *} & (1,142945) & (0,2878857) & (-0,7421552)\end{array}$

$R^{2}=0,74409715 \quad n=17 \quad F=7,915621^{*} \quad D W=2,06118937$

3) $\mathrm{Aep}=110.985,7+22.104,61 \mathrm{P}^{P_{t-1}}+23,81363 I_{t}+48.206,92 \mathrm{Dt}-1.304,75 \mathrm{Pr}_{t-1}$

$R^{2}=0,73127785 \quad n=17 \quad F=10,77387^{* *} \quad D W=1,93006449$

\section{Utilizando logaritmos neperianos na situação anterior:}

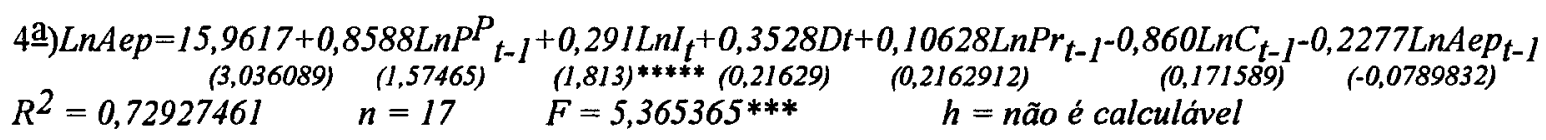

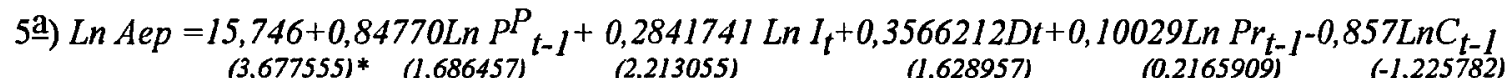

$R^{2}=0,72910572 \quad n=17 \quad F=7,371064^{* *} \quad r .002,35222186$

\section{Utilizando média móvel anual para as variáveis $P^{P}$ e C (t e t-1):}

$$
\begin{aligned}
& 6 \underline{\mathrm{a}}) \mathrm{Aep}=41.910,4+41.696,03 \mathrm{Pp}_{t, t-1}+16,8198 I_{t}+61.584,5 D t+3.191,496 \mathrm{Pr}_{t-1}-32,8234 C_{t, t-1}+0,0959 A e p_{t-1}
\end{aligned}
$$

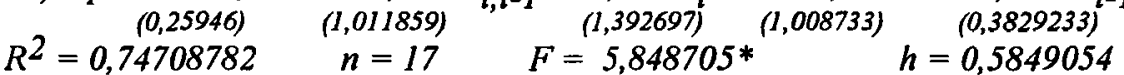




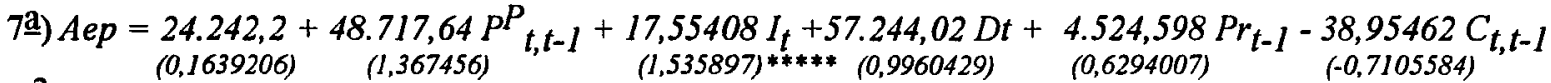
$R^{2}=0,74372481 \quad n=17 \quad F=7,900350 * * \quad D W=2,10287692$

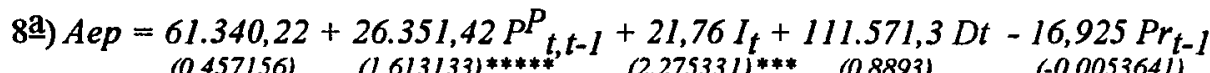

$R^{2}=0,729321 \quad n=17 \quad F=10,81158^{* *} \quad D W=2,54808045$

\section{Utilizando logaritmos neperianos na situação anterior}

9a) $\operatorname{LnAep}=16,082+1,1356 \operatorname{LnP}_{t, t-1}+0,2166 \operatorname{LnI}_{t}+0,3057 \mathrm{Dt}+0,4157 \operatorname{LnPr}_{t-1}-0,9105 \operatorname{LnC}_{t, t-1}-0,0676 \operatorname{LnAep}_{t-1}$

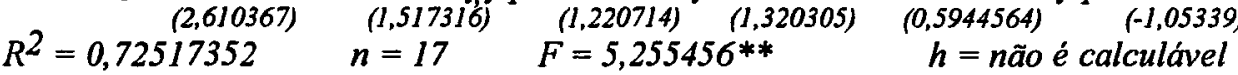

10䇋 $\operatorname{Ln}$ Aep $=15,263+1,07755 \operatorname{Ln} P_{t, t-1}+0,1991 \operatorname{Ln} I_{t}+0,3152 D t+0,368773 \operatorname{Ln} P_{t-1}-0,86768 \operatorname{Ln} C_{t, t-1}$ $R^{2}=0,72372760 \quad n=17 \quad F=7,174039 * * \quad(1,446389) \quad(0,5768842)$

Utilizando média móvel bianual para as variáveis $P P, C$ (t e t-1) e Pr (t-1 e t-2):

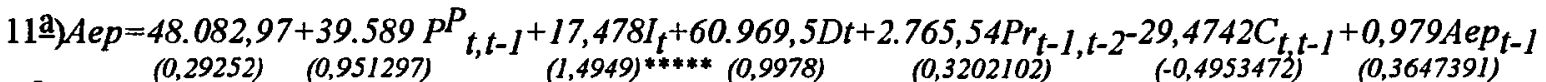
$R^{2}=0,7459839 \quad n=17 \quad F=5,814595^{* *} \quad h=$ não é calculável

12a) $A e p=27.951+46.941,72 P_{t, t-1}+18,2149 I_{t}+56.780,32 D t+4.279,363 P_{t-1, t-2}-36,456 C_{t, t-1}$ $\begin{array}{cccc}(0,1881) & (1,343357) & (1,6479) * * * * & (0,9853573) \\ R^{2}=0,74260461 & n=17 & F=7,853999 * * & (0,5886836) \\ & & D=2,54369725\end{array}$

13a) $A e p=62.876,07+26.228,10 P_{t, t-1}+21,82542 I_{t}+39.684,51 D t-59,34168 \operatorname{Pr}_{t-1, t-2}$

$R^{2}=0,73196853 \quad n=17 \quad F=10,81194^{* *} \quad D W=2,389749$ 


\section{APÊNDICE E - Teste da Equação da Área Reflorestada/Florestada para as Empresas de Papel e Celulose}

Testamos, pelo Método dos Mínimos Quadrados Ordinários, para o período de 1982 a 1993, a seguinte equação:

$A_{t}=B_{0}+B_{1} P_{t-k}^{P}+B_{2} I_{t}+B_{3} P_{t-k}+B_{4} C_{t-k}+B_{5} A_{t-k}$

Onde esperamos $\operatorname{ser} B_{1}>0, B_{2}>0, B_{3}>0, B_{4}<0$ e $B_{5}>0$.

As equações obtidas são apresentadas a seguir.

Os valores entre parênteses sob os coeficientes estimados referem-se à estatística t.

Além disso,

* indica o coeficiente ser estatisticamente significativo a $0,05 \%$;

** indica o coeficiente ser estatisticamente significativo a $1 \%$;

$* * *$ indica o coeficiente ser estatisticamente significativo a $5 \%$;

$* * * *$ indica o coeficiente ser estatisticamente significativo a $10 \%$;

$* * * * *$ indica o coeficiente ser estatisticamente significativo a $20 \%$. 


\section{Utilizando valores anuais e variáveis defasadas em 1 ano (exceto $I_{\mathfrak{t}}$ ):}

19) $\mathrm{Aep}_{t}=32.212,23+761.305,1 \mathrm{P}_{t-1}-13,05784 I_{t}+782,1457 \mathrm{Pr}_{t-1}+12,95372 C_{t-1}-0,4778 \mathrm{Aep}_{t-1}$ $(0,40055) \quad(1,774672)^{* * * * *} \quad(-2,454055)^{* * *} \quad(0,4310339) \quad(1,751384)^{* * * * *} \quad(-1,2796)$

$R^{2}=0,83906 \quad n=12 \quad F=6,256^{* *} \quad h=$ não é calculável

\section{Utilizando logaritmos neperianos na situação anterior:}
2a) $\operatorname{LnAep}_{t}=8,9886+0,1791 \mathrm{LnP}_{t-1}-0,034 \mathrm{LnI}_{t}+1,244773 \operatorname{LnPr}_{t-1}+1,15809 \mathrm{C}_{t-1}-0,871 \mathrm{LnAep}_{t-1}$ $(1,9792)^{* * *}(1,43712)^{* * * * *} \quad(-1,18506) \quad(1,612)^{* * * * *} \quad(1,60575)^{* * * * *}(-1,4249)$
$R^{2}=0,7830 \quad n=12 \quad F=4,331169 * * \quad h=$ não é calculável

Utilizando média móvel anual para as variáveis $\mathbf{P}$ e Pr (t e t-1):

39) $A e p_{t}=39.443,43+1.997 .950 P p_{t, t-1}-6,09 I_{t}+730,99 \operatorname{Pr}_{t-1}+3,04 C_{t, t-1}-0,166$ Aep $_{t-1}$ $(0,6639457) \quad(3,273322) * * \quad(-1,268981) \quad(0,4477687) \quad(0,35797722) \quad(-0,4810277)$

$R^{2}=0,909 \quad n=12 \quad F=11,87 * \quad h=$ não é calculável

Utilizando logaritmos neperianos na situação anterior

4.) $\operatorname{LnAep}_{t}=12,697+0,746 \operatorname{LnP}_{t-1}+0,06828 \operatorname{LnI}_{t}+0,667 \operatorname{LnPr}_{t-1}-1,3909 \operatorname{LnC} C_{t-1}+0,993 \operatorname{LnAep} t-1$ $(5,386608) *(5,608294)^{*} \quad(2,800181)^{* *} \quad(1,553975) * * * * *(-2,353924) * * \quad(2,089111)^{* * *}$

$R^{2}=0,95172589 \quad n=12 \quad F=23,65805^{*} \quad h=$ não é calculável 